\title{
Redressing the gender gap
}

Citation for published version (APA):

Silva Vara, A. P. (2017). Redressing the gender gap: conditional cash transfers and women's experiences of empowerment in Brazil and Mexico. [Doctoral Thesis, Maastricht University]. Boekenplan Maastricht. https://doi.org/10.26481/dis.20171211as

Document status and date:

Published: 01/01/2017

DOI:

10.26481/dis.20171211as

Document Version:

Publisher's PDF, also known as Version of record

\section{Please check the document version of this publication:}

- A submitted manuscript is the version of the article upon submission and before peer-review. There can be important differences between the submitted version and the official published version of record.

People interested in the research are advised to contact the author for the final version of the publication, or visit the DOI to the publisher's website.

- The final author version and the galley proof are versions of the publication after peer review.

- The final published version features the final layout of the paper including the volume, issue and page numbers.

Link to publication

\footnotetext{
General rights rights.

- You may freely distribute the URL identifying the publication in the public portal. please follow below link for the End User Agreement:

www.umlib.nl/taverne-license

Take down policy

If you believe that this document breaches copyright please contact us at:

repository@maastrichtuniversity.nl

providing details and we will investigate your claim.
}

Copyright and moral rights for the publications made accessible in the public portal are retained by the authors and/or other copyright owners and it is a condition of accessing publications that users recognise and abide by the legal requirements associated with these

- Users may download and print one copy of any publication from the public portal for the purpose of private study or research.

- You may not further distribute the material or use it for any profit-making activity or commercial gain

If the publication is distributed under the terms of Article $25 \mathrm{fa}$ of the Dutch Copyright Act, indicated by the "Taverne" license above, 


\title{
Redressing the Gender Gap
}

\author{
Conditional Cash Transfers \\ and Women's Experiences of Empowerment in \\ Brazil and Mexico
}

Ana Patricia Silva Vara 
ISBN 9789086664351

Copyright by Ana Patricia Silva Vara, Maastricht 2017

Cover Illustration: Luis Roberto Silva Vara

Printing: Boekenplan, Maastricht 


\section{Redressing the Gender Gap}

\section{Conditional Cash Transfers and Women's Experiences of Empowerment in Brazil and Mexico}

\section{DISSERTATION}

to obtain the degree of Doctor at Maastricht University, on the authority of the Rector Magnificus,

Prof. Dr. Rianne M. Letschert, in accordance with the decision of the Board of Deans, to be defended in public on Monday 11 December 2017, at 12.00 hours

by

Ana Patricia Silva Vara 


\section{Supervisor:}

Prof. Dr. Chris de Neubourg, University of Tilburg

\section{Co-supervisor:}

Dr. Katrin Križ, Emmanuel College, Boston, USA

\section{Assessment Committee:}

Prof. Dr. Frank Cörvers (Chair)

Prof. Dr. Mineke Bosch, University of Groningen

Prof. Dr. Franziska Gassmann, Bonn-Rhein-Sieg University of Applied Science Dr. Zina Nimeh 
For Emma and Ana,

My grandmothers and

pioneers of women's empowerment in Mexico 



\section{Acknowledgements}

To undertake and to finish a PhD requires not only personal commitment, selfdiscipline and effort, but the intellectual, emotional and financial support of many people. I would like to take this moment to acknowledge and thank all the people who have made this academic achievement possible.

First of all I would like to thank my advisors Prof. Dr. Chris de Neubourg and Dr. Kati Križ. Chris, thank you for your interest in my research since the very beginning, when it was just a preliminary proposal. Thank you for your input and comments, and for suggesting to include Brazil in the study, which rounded up this research. It was a privilege and a rich learning opportunity to work under your guidance. Kati, thank you so much for your meticulous guidance, for your time, comments and encouragement. You always reminded me of the value of my research. Thank you for discussing in-depth every idea, model and finding, and for carefully reading every line I wrote. Your ideas and advice have been invaluable to my work, and they allowed me to finally have my book.

I would also like to thank many people in Maastricht for sharing their time and knowledge: Prof. Dr. Robin Cowan, Prof. Dr. Franziska Gassmann, Dr. Lutz Krebs, Dr. Zina Nimeh, Dr. Tatiana Skripka, Prof. Dr. Luc Soete, Dr. Mindel van de Laar and Prof. Dr. Bart Verspagen. You have provided me with inspiration, knowledge, and words of encouragement throughout this process. For creating a welcoming environment and for their support on administration and logistics, I thank Ad, Danny, Herman, Howard, Marc, Mieke, Mourik Jan, Sueli, Susan and Wilma. Especially, I would like to thank Eveline In de Braek for her continuously kind support, her exceptional guidance through the bureaucratic and logistical road to the defense, and for getting the defense procedures ready.

I would also like to take this opportunity to thank the institutions that provided me with the financial means to undertake and to complete this intellectual adventure. Thanks go to the Fundación Pablo García and to the Consejo Nacional de Ciencia y Tecnología (CONACYT). Furthermore, I would like to thank the people that made my field research in Campeche and in Ceará possible. In Campeche, I am grateful to the members of the Fundación Pablo García, of the Sistema Nacional para el Desarrollo Integral de la Familia (DIF), and to the officials of the Oportunidades programme for their help in navigating my way through the poorest communities and finding the interviewees of this study. 
In Ceará, I am forever indebted to the people who made my work go smoothly and who welcomed me in their country and in their homes: Jaina Alcantara, Fabiola Costa, Patricia Ferreira, Raquel Honorio, Sara Martins and Belchior Torres. I would also like to thank all the interviewees in Campeche and in Ceará who shared their time, input and insights with me. It is they who provided me with their voices for this book.

I am very grateful to my reading committee Prof. Dr. Frank Cörvers, Prof. Dr. Mineke Bosch, Prof. Dr. Franziska Gassmann and Dr. Zina Nimeh for accepting this task, for their time and their interest in the book, and for their insightful comments and constructive suggestions on it.

From the time before this $\mathrm{PhD}$ was a reality, I would like to thank some people who guided and nourished my intellectual interest in the topic of social protection: Prof. Dr. Carlos Alba from my alma mater in Mexico, and Christof Kersting, Ellen Kramer and Dr. Matthias Rompel from GIZ in Germany. From a personal perspective, I would like to thank Alba, Bárbara, Enrique, Léonie, Leonor, Luis, María, Nuria, Perla, Roberto and Sandra for their friendship of a lifetime.

In Maastricht, I would like to thank my PhD cohort fellows Andrea, Hang Wong, Mahmut, Omar, Paula, Richard, Serdar and Valery. I also thank Alejandro, Cheng, Esther, Florian, Ilire, Julieta, Luciana, Raquel, Raschad, Sebastián, Sepideh and Shuan for the talks and walks, dinners and wines that made my time in Maastricht unforgettable. Also especially, I would like to thank Florian and Roberto for giving me the joy of being my paranymphs.

Finally, I would like to thank my family, who have always and unconditionally been there for me. Thank you to my father Luis Roberto and to my mother Patricia, for their unending love and unquestioning support. They have always been there for me, providing me with a loving and caring family, with the belief that with hard work and determination I could achieve all my dreams and goals, and with the knowledge that I have a stable place that I can always call home. I would also like to thank my brother Roberto, for always being my best friend and source of wisdom and sanity, wherever we might be. Lastly, I would like to thank my dear husband and travel partner, Francis. He has been by my side since the beginning of this PhD journey, through the highs and lows, providing me with love, strength, and adoration. I hope that this achievement is just the beginning of a new stage in a wonderful life together. 


\section{Contents}

Abbreviations $\quad$ ix

Executive Summary $\quad$ xi

Overzicht xiii

Resumen Ejecutivo $\quad$ Xv

Chapter 1. Introduction 1

1.1 Introduction 1

1.2 Research Questions 4

1.3 Conditional Cash Transfers (CCTs) and Women's Empowerment 4

1.4 Case Studies 9

1.4.1 Oportunidades/Prospera in Mexico $\quad 10$

$\begin{array}{ll}\text { 1.4.2 Bolsa Família in Brazil } & 12\end{array}$

1.5 Relevance, Scope and Limitations of the Research 14

1.6 Structure of the Dissertation 16

Chapter 2. The Feminization of Poverty and Conditional Cash Transfers 17

2.1 Introduction 17

2.2 The Feminization of Poverty, Gender and Social Protection 18

2.2.1 The Feminization of Poverty 18

2.2.2 Social Protection and Gender $\quad 23$

2.2.3 Women and the Gender Gap in Poverty 25

2.3 Conditional Cash Transfer Programmes (CCTs) as a Gendered 27 Approach to Social Protection

2.3.1 CCT Case Study 1: Oportunidades/Prospera in Mexico 28

2.3.2 CCT Case Study 2: Bolsa Família in Brazil 33

2.4 Previous Findings About the Impact of CCTs on the Empowerment 37 of Women in Latin America

2.5 Conclusion 41

Chapter 3. Theoretical Framework of Empowerment and Research Methods 43

3.1 Introduction $\quad 43$

3.2 The Concept of Empowerment 44

3.2.1 Empowerment in the International Arena 44

3.2.2 Definition of Empowerment $\quad 45$

3.2.3 Challenges in the Measurement of Empowerment 49

3.3 Rationale for Choice of Research Methods, Cases and Research 51 Sites 
3.3.2 Sample Description $\quad 59$

3.3.3 Data Analysis $\quad 62$

3.4 Limitations $\quad 62$

Chapter 4. CCTs and Women's Participation in the Labour Market 64

4.1 Introduction 64

4.2 Literature Review 66

4.2.1 Cash Transfers and Labour Supply 66

4.2.2 Previous Findings from Latin America on the Impact of CCTs 69 on Women's Labour Market Participation

4.3 Methods

4.4 Findings $\quad 76$

4.4.1 Labour Market Participation $\quad 76$

4.4.2 Women's Work and Desire to Work Before and After Transfers 78

4.4.3 The Meaning of Work $\quad 80$

4.4.4 Motivation to Work $\quad 81$

4.4.5 Barriers to Work $\quad 82$

4.4.6 The Employment Trigger-Effect of CCTs 82

4.5 Conclusion $\quad 85$

Chapter 5. CCTs and Women's Intra-household Decision-Making $\quad 87$

$\begin{array}{ll}\text { 5. } 1 \text { Introduction } & 87\end{array}$

5.2 Literature Review $\quad 88$

5.2.1 Models of Intra-Household Decision-Making 88

5.2.2 A Gendered Perspective on Intra-Household Decision-Making 89

5.2.3 Previous Findings in Mexico and Brazil on the Impact of $\quad 91$

CCTs on Intra-Household Decision-Making

5.2.3.1 Oportunidades/Prospera 92

5.2.3.2 Bolsa Família $\quad 95$

5.3 Methods 97

5.4 Findings $\quad 98$

5.4.1 Economic Decisions $\quad 99$

5.4.1.1 Women's Attitudes and Views About the CCT's Money 102

5.4.2 Decision-Making Regarding Children's Issues 103

5.4.3 Decision-Making Regarding Personal Decisions 105

5.4.4 Decision-Making About Reproductive Health 106

5.4.5 Decision-Making About Mobility 110

5.4.6 Decision-Making Areas 114

5.5 Discussion and Conclusions 117 
6.1 Introduction 120

6.2 Methods 121

6.3 Findings 122

6.3.1 Self-Confidence and Self-Worth 123

6.3.2 Personal Empowerment Awareness or Agency Consciousness 125

6.3.3 Beneficiaries' Perceptions of Educational Talks 126

6.3.4 Change of Habits and Change of Behaviour: 128

Domestic Violence Awareness and Parenting Empowerment

6.3.5 Increase in Respect since Receiving the Transfers 131

6.3.6 Other Perceptions 131

6.3.6.1 Cross-Country Differences in the Meaning of the $\quad 131$

Transfers

6.3.6.2 Aspirations for More Economic Opportunities $\quad 132$

6.3.6.3 A Desire for Men's Inclusion in the Programmes 133

6.4 Concluding Remarks 134

Chapter 7. Conclusions, Policy Implications and Suggestions for Future $\quad 136$

Research

7.1 Restatement of Research 136

7.2 Main Findings 136

7.2.1 CCTs and the Labour Market 139

7.2.2 CCTs and Intra-household Decision-Making 143

7.2.3 CCTs and Women's Experiences of Empowerment 146

7.3 Policy Implications $\quad 150$

7.4 A Way Forward: Suggestions for Future Research 154

$\begin{array}{ll}\text { Annexes } & 157\end{array}$

1. Interview Guide for Oportunidades Beneficiaries 157

2. Interview Guide for Bolsa Família Beneficiaries $\quad 160$

3. Interview Guide for Non-Beneficiaries 163

4. Oportunidades/Prospera's Transfers by Component, $\quad 165$ First Semester 2015

5. Bolsa Família's Transfers, 2014

6. Tables on Labour Market Participation, Intra-household Decision- 168 making, and Self-worth

$\begin{array}{ll}\text { Short Biography } & 183\end{array}$

$\begin{array}{ll}\text { Bibliography } & 185\end{array}$ 


\section{Tables}

2.1 Gender and poverty in Latin America $\quad 21$

3.1 Sample demographics $\quad 60$

4.1 Interviewees' work before and after transfers and self-reported desire to $\quad 78$ work

5.1 Interviewees' self-reported decision-making power in the area of children's 104 issues

5.2 Interviewees' self-reported decision-making power in the area of personal 105 decisions

5.3 Reported wife and husband/partner's decision-making areas in household 116

6.1 Interviewees' own perception of opinion valued at home and if their opinion has the same weight as their husbands'

6.2 Topics discussed in educational talks

\section{Boxes}

1.1 Empowerment indicators $\quad 9$

2.1 Oportunidades' transfers $\quad 32$

2.2 Federal CCTs in Brazil $\quad 35$

2.3 The Bolsa Família Programme 36

5.1 Dimensions of decision-making, indicators and measurement 98

5.2 The case of sterilisation surgeries in Tenabo, Mexico 110

7.1 CCTs' main effects by area of empowerment 137

$\begin{array}{ll}7.2 \text { Other main findings } & 138\end{array}$ 


\section{Figures}

$\begin{array}{ll}1.1 \text { Kabeer's empowerment framework } & 7\end{array}$

3.1 Empowerment framework 46

3.2 Map of Mexico, showing Campeche $\quad 54$

3.3 Map of Brazil, showing Ceará $\quad 54$

3.4 Age of interviewees (frequency) 60

3.5 Women's number of children (frequency) 61

3.6 Number of people living in the household (frequency) 61

4.1 Interviewees' self-reported labour market participation $\quad 76$

4.2 Classification of working and non-working beneficiaries $\quad 80$

5.1 Interviewees' self-reported decision-making power in the area of 99

household expenditure

5.2 Interviewees' self-reported decision-making power in the area of $\quad 107$ reproductive health

5.3 Interviewees' self-reported ability to use contraception 109

5.4 Oportunidades' and Bolsa Família's beneficiaries and non-beneficiaries' 111 self-reported decision-making power in the area of mobility

5.5 Interviewees' self-reports about person who makes most decisions in the 115 household

6.1 Effects of CCTs on beneficiaries' personal empowerment 130

7.1 Barriers to women's empowerment $\quad 139$

$\begin{array}{ll}7.2 \text { Enhanced empowerment framework } & 149\end{array}$ 


\section{Abbreviations}

\begin{tabular}{|c|c|}
\hline ADB & Asian Development Bank \\
\hline $\mathrm{BFP}$ & Bolsa Família Programme \\
\hline BPFA & Beijing Platform for Action \\
\hline CCT & Conditional Cash Transfer Programmes \\
\hline CEF & Federal Economic Fund \\
\hline CONEVAL & $\begin{array}{l}\text { National Council for the Evaluation of Social Development } \\
\text { Policy }\end{array}$ \\
\hline DFID & Department for International Development \\
\hline ECLAC & $\begin{array}{l}\text { Economic Commission for Latin America and the } \\
\text { Caribbean }\end{array}$ \\
\hline ENCASEH & Survey of Socio-Economic Household Characteristics \\
\hline ENCEL & Survey of Household Evaluation \\
\hline ENIGH & National Survey on Households' Income and Expenditure \\
\hline INEGI & National Institute of Statistics, Geography and Informatics \\
\hline $\mathrm{FAO}$ & Food and Agriculture Organisation of the United Nations \\
\hline $\mathrm{FHH}$ & Female-Headed Household \\
\hline GAD & Gender and Development \\
\hline GAP & Gender Action Plan \\
\hline GDP & Gross Domestic Product \\
\hline GIZ & German International Cooperation Agency \\
\hline HDR & Human Development Report \\
\hline IDB & Inter-American Development Bank \\
\hline ILO & International Labour Organisation \\
\hline IPC & International Poverty Centre \\
\hline LAC & Latin American Countries \\
\hline MDG & Millennium Development Goals \\
\hline MDS & Ministry for Social Development and to Combat Hunger \\
\hline
\end{tabular}


MXN

NGO

NPA

OECD

Oportunidades

PAN

PNAD

PRI

PROGRESA

PRONASOL

PROSPERA

PRSP

$\mathrm{R} \$$

SAP

SDG

SEDESOL

USD

UN

UNDP

UNIFEM

WB

WEM

WHO

WID

WTO
Mexican Peso

Non-Governmental Organisation

New Poverty Agenda

Organisation for Economic Cooperation and Development

Programme for Human Development - Opportunities

Party for National Action

National Survey by Household Sampling

Revolutionary Institutional Party

Programme for Education, Health and Nutrition

National Programme for Solidarity

Programme for Social Inclusion

Poverty Reduction Strategy Papers

Brazilian Real

Structural Adjustment Programme

Sustainable Development Goals

Ministry for Social Development

United States Dollar

United Nations Organisation

United Nations Development Programme

United Nations Development Fund for Women- UN

Women since 2011

World Bank

Women's Empowerment Matrix

World Health Organisation

Women in Development

World Trade Organisation 


\section{Executive Summary}

Conditional cash transfer programmes (CCTs), which provide money subsidies to targeted households living in extreme poverty, are some of the salient policy instruments used for poverty alleviation in the Global South today. These programmes employ a gendered approach as they provide the money to the mothers of families living in extreme poverty. The objective of this book is to provide in-depth knowledge about how women living in extreme poverty experience the effect of the CCTs on their empowerment. Using the Oportunidades/Prospera programme in Mexico and the Bolsa Família programme in Brazil as case studies, this research identifies the cultural, social and policy conditions that need to be in place for the empowerment process to occur in different areas of women's lives, notably labour market participation, intrahousehold decision-making and self-worth. In this study, empowerment is defined as a process by which people who have previously been denied or have not had the opportunity and the ability to make choices obtain such an ability.

The assumption undergirding this book is that families who receive CCTs experience a change of intra-household dynamics that can foster women's empowerment, due to the fact, among others, that women have more control over resources and perceive a positive change in their social status. This assumption is based on the review of the literature, which is presented in Chapter 2. The assumption was also that empowerment effects can depend on women's social and cultural context (i.e. particular country, rural vs. urban communities, cultural issues)-hence the comparative research design, which is discussed in Chapter 3. A case study approach was employed using qualitative methods. The data for this study was obtained through semi-structured in-depth interviews conducted with 120 beneficiaries and non-beneficiaries in three communities in Campeche (Mexico) and Ceará (Brazil) in 2012.

Chapters 4, 5 and 6 discuss the empirical findings of this study. Chapter 4 presents the link between CCTs and women's labour market participation and shows that CCTs had a two-fold effect on the study participants: CCTs substituted income and had an employment trigger-effect. Chapter 5 demonstrates that CCTs' empowerment effect on intra-household decision-making was dampened by the persistence of traditional gender norms. The findings also show that, not surprisingly perhaps, education and empowerment are intrinsically linked, and women's higher education level was related to higher decision-making power. Chapter 6 provides details on the perceived effects that CCTs have on the lives of the beneficiaries and on the beneficiaries' experiences of empowerment. This 
chapter shows that CCTs contributed to some empowerment processes, which were called personal empowerment awareness, domestic violence awareness and parenting empowerment. Furthermore, it demonstrates that beneficiaries would like the programmes to include more access to education, income-generating opportunities and provide men with access to the programme's activities as well.

Finally, Chapter 7 presents lessons learnt and discusses policy considerations and opportunities for future research. It suggests that CCTs can better foster women's empowerment when they are linked to education and argues that structural policies that provide economic support together with education can create the seed for an empowerment process and improved well-being for this vulnerable population. Furthermore, it recommends providing educational talks as a CCT component in Brazil, and providing access to income-generating opportunities for the beneficiaries in both countries. This access could also mean an exit strategy or "graduation" from the transfer programmes, after women have improved their economic level in a sustainable way and are no longer depending on the government. 


\section{Overzicht}

Voorwaardelijke overboekingsprogramma's (CCT's) die subsidies geven aan geselecteerde gezinnen die in extreme armoede leven, zijn enkele van de belangrijkste beleidsinstrumenten die vandaag worden gebruikt voor de verlichting van armoede in de Global South. Deze programma's gebruiken een op geslacht gebaseerde aanpak aangezien zij het geld aan vrouwelijke gezinshoofden geven. Het doel van dit boek is om een diepgaand inzicht te geven over hoe vrouwen die in extreme armoede leven, de impact van de CCT's op hun zeggenschap zien. Met behulp van het Oportunidades/Prospera-programma in Mexico en het Bolsa Família-programma in Brazilië als gevalsstudies, identificeert dit onderzoeksproject de noodzakelijk culturele, sociale en politieke voorwaarden om het zeggenschapsproces op verschillende gebieden van het leven van vrouwen te laten bestaan, met name arbeidsmarktparticipatie, besluitvorming in het gezin en zelfwaarde. In deze studie definieer ik zeggenschap als een proces waarbij mensen die eerder zijn geweigerd of niet de kans hebben gehad om keuzes te maken, de kans krijgen om dit te doen.

De onderliggende veronderstelling van dit boek, is dat families die CCT's ontvangen, een verandering in de dynamiek van de huishoudens ervaren die de zeggenschap van vrouwen kunnen bevorderen, onder meer doordat vrouwen meer controle hebben over middelen en een positieve verandering in hun sociale status zien. Deze veronderstelling is gebaseerd op mijn beoordeling van de literatuur, die ik in Hoofdstuk 2 presenteer. Mijn veronderstelling was ook dat de effecten van de zeggenschap kunnen afhangen van de sociale en culturele context van vrouwen (m.a.w. een bepaald land, platteland/stedelijke gemeenschappen, culturele kwesties), vandaar mijn vergelijkende onderzoeksontwerp dat ik in Hoofdstuk 3 bespreek. Ik heb een gevalstudie-benadering met behulp van zowel kwantitatieve als kwalitatieve methoden, gebruikt. Ik heb de gegevens voor deze studie verkregen door middel van semigestructureerde, diepgaande interviews die ik in 2012 met 120 begunstigden en niet-begunstigden in drie gemeenschappen in Campeche (Mexico) en Ceará (Brazilië) heb uitgevoerd.

Hoofdstukken 4, 5 en 6 bespreken de empirische bevindingen van deze studie. Hoofdstuk 4 presenteert het verband tussen CCT's en de arbeidsmarktparticipatie van vrouwen en toont aan dat CCT's een tweeledig effect hebben op de deelnemers aan de studie: CCT's werden een vervangingsinkomen en hadden een stimulerend effect op tewerkstelling. Hoofdstuk 5 toont aan dat de invloed van de CCT's op de besluitvorming binnen het gezin door de volharding van traditionele gendernormen wordt geremd. Uit mijn bevindingen blijkt ook dat het niet 
verrassend is dat onderwijs en zeggenschap intrinsiek met elkaar verbonden zijn, en dat een hoger onderwijsniveau van de vrouw in gerelateerd is aan een hogere beslissingsbevoegdheid. Hoofdstuk 6 geeft meer informatie over de perceptie van de gevolgen die CCT's hebben op het leven van de begunstigden. In dit hoofdstuk blijkt dat CCT's bijgedragen hebben tot een aantal zeggenschapsprocessen, die ik de persoonlijke zeggenschap-bewustmaking noem, en tot een hoger bewustzijn van huiselijk geweld en emancipatie binnen de ouderlijke rol. Voorts blijkt dat begunstigden willen dat de programma's meer toegang zouden geven tot onderwijs en opportuniteiten die inkomen genereren en dat de mannen ook toegang krijgen tot de activiteiten van het programma.

Ten slotte presenteert Hoofdstuk 7 de geleerde lessen en worden beleidsoverwegingen en kansen voor toekomstig onderzoek besproken. Het suggereert dat CCT's de zeggenschap van vrouwen beter kunnen bevorderen wanneer ze gekoppeld zijn aan onderwijs en pleite dat structurele beleidsmaatregelen die samen met onderwijs, economische ondersteuning bieden, het zaad kunnen creëren voor een zeggenschapsproces en een beter welzijn voor deze kwetsbare bevolking. Daarenboven beveelt het aan om educatieve gesprekken als een CCT-onderdeel aan te bieden in Brazilië en toegang te verschaffen tot kansen die inkomen genereren voor de begunstigden in beide landen. Deze toegang kan ook een exit-strategie of "graduatie" betekenen van de overdrachtsprogramma's, nadat vrouwen hun economische niveau op een duurzame manier hebben verbeterd en niet meer afhankelijk zijn van de overheid. 


\section{Resumen Ejecutivo}

Los programas de transferencias condicionadas (CCT por sus siglas en inglés), que proporcionan subsidios monetarios a hogares seleccionados que viven en la pobreza extrema, son algunos de los principales instrumentos de política social utilizados para aliviar la pobreza en los países en desarrollo. Estos programas emplean un enfoque de género, ya que proporcionan el dinero a las madres de familia. El objetivo de este libro es proporcionar un conocimiento profundo sobre cómo las mujeres que viven en pobreza extrema ven el efecto de los CCT en su empoderamiento. Mediante el uso del programa Oportunidades/Prospera en México y del programa Bolsa Familia en Brasil como casos de estudio, este proyecto de investigación identifica las condiciones culturales, sociales y de políticas que deben existir para que el proceso de empoderamiento ocurra en diferentes áreas de la vida de las mujeres, en especial en la participación en el mercado laboral, la toma de decisiones dentro del hogar y la autoestima. En este estudio, el empoderamiento se define como el proceso por el cual las personas a quienes previamente se les ha negado, o no han tenido la oportunidad y la capacidad de tomar decisiones, obtienen tal habilidad.

La hipótesis que subyace en este libro es que las familias que reciben CCT experimentan un cambio en la dinámica intra-familiar que puede fomentar el empoderamiento de las mujeres, debido, entre otras cosas, a que las mujeres tienen más control sobre los recursos y perciben un cambio positivo en su condición social. Esta hipótesis se basa en la revisión de la literatura, la cual se presenta en el Capítulo 2. El supuesto fue que los efectos del empoderamiento pueden depender del contexto social y cultural de las mujeres (es decir, de un país en particular, de las comunidades rurales frente a las urbanas, de las cuestiones culturales). De ahí el diseño de investigación comparada, que se discute en el Capítulo 3. Se empleó un enfoque de casos de estudio utilizando métodos cualitativos. Los datos para este estudio se obtuvieron por medio de entrevistas semi-estructuradas exhaustivas que se llevaron a cabo con 120 beneficiarias y no beneficiarias en tres comunidades de Campeche (México) y Ceará (Brasil) en 2012.

En los Capítulos 4, 5 y 6 se habla sobre los hallazgos empíricos de este estudio. El Capítulo 4 presenta el vínculo entre los CCT y la participación de las mujeres en el mercado laboral y muestra que los CCT tuvieron un doble efecto en los participantes del estudio: los CCT sustituyeron el ingreso y tuvieron un efecto desencadenante en el empleo. El Capítulo 5 demuestra que el efecto del empoderamiento de los CCT en la toma de decisiones dentro del hogar fue atenuado por la persistencia de las normas tradicionales de género. Tal vez no 
sorprendentemente, las conclusiones también muestran que la educación y el empoderamiento están intrínsecamente vinculados, y un nivel de educación superior de las mujeres se relaciona con un mayor poder de decisión. El Capítulo 6 proporciona detalles sobre los efectos percibidos que los CCT tienen sobre la vida de las beneficiarias. Este capítulo muestra que los CCT contribuyeron a algunos procesos de empoderamiento, los cuales se nombraron "conciencia de empoderamiento personal", "conciencia de violencia doméstica" y "empoderamiento de crianza". Más aún, demuestra que a las beneficiarias les gustaría que los programas incluyeran un mayor acceso a la educación, oportunidades de generación de ingresos y brindar a los hombres acceso a las actividades del programa.

Finalmente, el Capítulo 7 presenta las lecciones aprendidas y discute las consideraciones de política y las oportunidades para futuras investigaciones. Sugiere que los CCT pueden fomentar mejor el empoderamiento de las mujeres cuando están vinculados a la educación y argumenta que las políticas estructurales que proporcionan apoyo económico junto con educación pueden crear la semilla para un proceso de empoderamiento y mejorar el bienestar de esta población vulnerable. Además, recomienda ofrecer pláticas educativas como un componente de los CCT en Brasil y proporcionar acceso a oportunidades generadoras de ingresos para las beneficiarias en ambos países. Este acceso también podría significar una estrategia de salida o "graduación" de los programas de transferencias, después de que las mujeres hayan mejorado su nivel económico de manera sostenible y que ya no dependan del gobierno. 
There is no tool for development more effective than the empowerment of women.

- Kofi Annan 


\section{Chapter 1. Introduction}

\subsection{Introduction}

This dissertation examines women's perceptions of the consequences of conditional cash transfer programmes (CCTs) on their empowerment, using the Oportunidades/Prospera ${ }^{1}$ programme in Mexico and the Bolsa Família programme in Brazil as case studies. The objective of this study is two-fold: 1) to provide more in-depth knowledge about how women beneficiaries living in the visited communities view the effect of the CCTs on their empowerment, and 2) based on this knowledge, find out what the conditions are that would need to be in place for CCTs to have an empowering effect on women beneficiaries who live in extreme poverty. The research questions that drive this study are: How do women beneficiaries perceive and experience CCT receipt in their lives, and how do they perceive the consequences of CCTs in the areas of labour market participation, intra-household decision-making and personal empowerment/self-worth? I thus hope to contribute to the scholarly debate on the gendered effect of CCTs and theories of women's empowerment and analyse under what conditions CCT programmes can help women beneficiaries achieve empowerment. This research was inspired by both personal experiences and earlier contributions by others.

This research was motivated by my educational background and professional interest. One day in late August 2009, while on a work mission in Hanoi, Vietnam, working for the German International Cooperation Agency (GIZ), I was walking back from the office to my hotel and I came by the Hoan Kiem lake. I started to reflect about what I was doing. I was on a two-month-mission in Vietnam to support the implementation of the first ever Vietnamese "National Strategy for Social Protection," which was going to run from 2010 to 2020. The government wanted to develop a strategy to protect the most vulnerable population from market shocks and life risks.

I had been working with social protection strategies since the last year of my BA degree and I had focused my MA on poverty reduction strategies. After that, I had conducted another post-graduate study for the German Development Institute and my final paper addressed conditional cash transfer programmes and their effect on gender relations and women's status. Due to this background, I had started to

\footnotetext{
${ }^{1}$ In September 2014 president Enrique Peña Nieto changed the name of the Oportunidades programme to Prospera. Previously, the programme had been called Oportunidades (since March 2002). The operational rules continue to be the same, thus throughout this dissertation I will use the Oportunidades and the Prospera names interchangeably, unless otherwise stated.
} 
work for GIZ at the beginning of 2008 in the headquarters in Eschborn, Germany. My work consisted of supporting best-practice transfers on social protection and poverty reduction strategies from my experience in Mexico to other countries in Latin America and South East Asia.

Back on that afternoon that changed my life, while I was walking by the lake, I started to wonder if the programmes that I was supporting made a real difference to the beneficiaries' lives. I was there telling the government what they needed to do. In the headquarters, we had it all figured out: "If you follow this and that strategy, there will be a $5 \%$ poverty reduction here, and a $10 \%$ increase on the education rate there." But was that really happening in the field? Could these wellthought policies reach the grass-root level? Was everything that I was supporting really making a difference in people's, especially women's, lives? And it was then that it hit me. I wanted to leave the policy level and go to the communities, go to the homes of the most vulnerable women and see what was happening. I wanted to see personally if there was a change as a result of these programmes. I wanted to hear, directly from the beneficiaries, what they felt about the programmes, and if they perceived their lives had been changed and how. This was the spark that ignited my passion for the topic of this dissertation. My idea was to go to the field, study what was happening, and then link this knowledge back to the policy level to create policy changes and adjustments that could help these programmes be more efficient and achieve their objectives in a better way, if this were necessary.

It was a bold decision to make-leaving my job at an important international agency and undertaking a PhD in Policy Planning and Policy Analysis. I did so because I wanted to research if conditional cash transfers that give money to the mothers/female primary care-givers of the households in extreme poverty were having an effect on their economic and social status, and their emotional wellbeing. I wanted to find out whether such programmes affect the way beneficiaries live, their work participation, their decision-making processes, and the way they perceive their self-worth. And afterwards, I wanted to extract lessons learned from this experience and link them back to the policy level to develop policy considerations.

The relevance of this research comes from the fact that poverty is arguably the most important problem faced by humankind, and among all the disadvantaged groups suffering from it women are one of the largest and most vulnerable (see Buvinic and Gupta, 1997; Klase et al., 2014; Say et al., 2014). Internationally, it has been recognised that the feminisation of poverty and the adverse impact of poverty on women are the consequence of inequalities embedded in norms, traditions, and practices that obstruct women's access to critical assets and resources such as land and credit, restrain their political and inheritance rights, and constrain their 
participation in society. In the developing world, in particular, this inequality can have extreme outcomes, such as higher mortality and lower nourishment and literacy rates for girls, and an increasing mortality rate for women during pregnancy and child-birth (see Say et al., 2014). "Empowerment" is defined as the "process by which those who have been denied the ability to make choices acquire such an ability" (Kabeer, 1999: 437), particularly in the areas of strategic life choices, such as choice of livelihood, whether and whom to marry, and whether to have children and how many. Therefore, it has become well-established that women's empowerment is fundamental to achieving poverty eradication and gender equality (see, for instance, UN, 2010).

The causes and outcomes of poverty are highly differentiated between women and men, particularly because of persistent unequal access to, and control over, productive resources and decision-making processes. Traditional conceptualisations of poverty in development policy consistently neglected to take this into account, resulting in policies and programmes which failed to improve the lives of poor women and men, and their families (see, for example, Del Campo et al., 2010). The acknowledgement of this unequal status quo by governments, international institutions, and policymakers during the last decades has led to the creation of a "gender approach" in poverty alleviation programmes, with the objective of jointly combating extreme poverty and reducing gender inequalities by bridging the gap between rights, assets, and participation of women and men in society (see for instance the Beijing Platform for Action, 1995). Important examples of this approach are conditional cash transfer programmes (CCTs), which target aid to female heads of family living in extreme poverty to invest in their human capital and help break the intergenerational poverty cycle (Molyneux, 2006).

The gender approach of CCT programmes shows a positive effect on women's empowerment (Adato and Roopnaraine, 2010); nonetheless, there is a lack of indepth and systematised analyses of the extent and features of such effect, as it will be shown below. As a consequence of the practitioners' and policymakers' plea for collecting and analysing in-depth information on the subject matter (Rawlings and Rubio, 2003; GIZ, 2009; Adato and Roopnaraine, 2010; UN, 2010; Szirmai, 2015) the objective of this research is to first, provide in-depth knowledge about how women beneficiaries perceive and experience the receipt of CCTs and their effect on their empowerment and, second, extrapolate from those findings under what conditions CCT programmes can help women to achieve empowerment. Using the Oportunidades/ Prospera programme in Mexico and the Bolsa Família programme in Brazil as case studies, this research identifies the cultural, social and policy conditions that need to be in place for the empowerment process to take place in different areas of the beneficiaries' lives, notably labour market participation, intra- 
household decision-making, and feelings of self-worth and personal empowerment.

\subsection{Research Questions}

In order to achieve its objective, the study focused on three main topics and research questions:

A. Labour market participation

Which access do women (beneficiaries and non-beneficiaries) living in the studied communities have to household resources? How is the labour market participation of these women changing due to CCTs (if at all)?

B. Intra-household decision-making

Has female domestic decision-making power increased ever since beneficiaries in the studied communities started receiving the CCTs? What is the gendered effect of CCTs on household decision-making? Who determines resource allocation/ spending? Can beneficiaries and non-beneficiaries move freely outside of their homes? Do beneficiaries and non-beneficiaries have the ability to make work and childbearing decisions?

C. Feelings of self-worth and personal empowerment

Do women beneficiaries feel more valued in their households by their family members as a result of the transfers? Do beneficiaries perceive that their feelings of self-worth have changed since receiving the CCTs?

\subsection{Conditional Cash Transfers (CCTs) and Women's Empowerment}

In the beginning of the development efforts in the 1960s, poverty alleviation programmes focused on a universal approach to poverty fighting. Men and women living in poverty were approached by undifferentiated social policies and the problems of gender inequality were not directly addressed. In fact, they were not even taken into account, since they were considered part of the status quo. Nonetheless, the 1990s saw significant shifts in thinking and practice around antipoverty policy in the development community. Delivery mechanisms moved away from general food price subsidies toward social safety nets and micro-credit programmes. Coverage also narrowed from universal benefits to targeted transfers, reflecting a hegemonic neo-liberal approach based on efficiency and costeffectiveness. Alongside these shifts, the issue of gender inequality became very important, and numerous governments, together with international institutions, donors and NGOs, started to implement a gender approach in their programmes (GIZ, 2009; UN, 2010).

Programmes that make cash transfers conditional on investment in human capital need to be judged in the context of a new approach to social protection. During the 
1980s, the social consequences of economic crises and Structural Adjustment Programmes (SAPs) led to a debate about the rationality of existing safety nets (Grindle, 2000; Bradshaw, 2008). The result of this debate was a policy focus on short-term poverty reduction, and social protection systems shifted towards a risk management approach aimed at enhancing human capital and defeating poverty in the longer term. Within this current, conditional transfer programmes were born from the concept of social protection as human capital investment. Their premise is that the reproduction of poverty across generations is due to a lack of investment in human capital, and they seek to foster this investment by attaching conditions to transfers (Villatoro, 2005: 84).

According to the social risk management approach (De Neubourg and Weigand, 2000; Holzmann and Jorgensen, 2000), individuals, households and communities are exposed to multiple risks. Poverty means greater vulnerability, since the poor have little access to suitable risk management instruments and are ill-placed to cope with crises. The mechanisms most used by poor families to deal with economic shocks are informal strategies (for example, taking their children, especially their daughters, out of school), whose inefficiency results in an irreversible loss of human capital and perpetuation of the intergenerational cycle of poverty (Molyneux, 2006). Social protection measures based on conditional cash transfers are human capital investments that enhance individuals' access to basic services and prevent the use of strategies with adverse long-term consequences, benefiting people living in structural poverty, those just above the poverty line, and groups with special needs (Barrientos, 2008).

Following this policy argument, from the mid-1990s onwards, the provision of conditional cash transfer programmes emerged as a fairly popular policy trend in the development agenda of Latin America. These programmes consist of the provision of money subsidies to targeted households living in extreme poverty, provided they assure school attendance of their children and attend periodic health-related activities (co-responsibilities or conditions). The innovation of these programmes is their capacity to address demand-side constraints for structural poverty reduction, through an incentive scheme which combines the short-term objectives of safety nets with the long term goal of building human capital and breaking the vicious circle of poverty traps (Britto, 2005; Gazola, 2015).

CCTs have a double effect within the effort of creating a sustainable strategy for poverty reduction: they have a component of immediate help and improvement of the nutritional consumption and basic goods of the beneficiaries due to the cash transfers, and they have a component of structural change through education and skill-building, which modifies one of the main causes of poverty: the lack of human capital. The medium and long term consequences of the CCTs allow the 
development of the beneficiaries' capabilities and help break the tendency of school desertion, malnutrition and preventable diseases that affects the lives and income possibilities of the poorest households (Devereux, 2016).

CCTs have received substantial support from the international community and are highlighted as one of the best practices of social protection in Latin America (Britto, 2005; Devereux and Solórzano, 2016). Their appeal is related to their potential for tackling key issues in the perpetuation of poverty, their fit with the current mainstream discourse on poverty reduction and their capacity to respond to two interrelated problems: the failure of universal social policies to reach the extremely poor (especially in the areas of education, health and nutrition), and the failure of the social protection systems in place to provide effective cushion mechanisms during crises.

At the beginning of the $21^{\text {st }}$, policymakers and institutions have acknowledged that women are the largest vulnerable group, and that measures need to be taken in order to help them empower themselves and break the poverty cycle. Following these criteria, women are increasingly targeted as beneficiaries of anti-poverty interventions, either to improve their well-being directly or as a mechanism for indirectly targeting other groups, especially young children, since it is assumed that women can maximise positive impacts of cash transfers, especially in the area of child nutrition (Oportunidades, 2006; Molyneux, 2007a). Arguments for privileging women over men reflect the view that women need economic and political empowerment to redress their disadvantaged status within households and communities (Devereux, 1999: 66).

The current focus on women's central role in welfare and development had its origins in the Women in Development (WID) approach in the 1970s, which sought to bring women into the development process and focused on their role in it. The idea of "empowerment through development" was introduced with WID but evolved as part of a Gender and Development (GAD) analysis that emerged in the late 1970s and 1980s. GAD analyses focused on the dynamics and structures of gender relations and gender inequalities. In addition, the GAD approach examined how gender relations shape the nature of basic constructs of development analysis (households, labour markets or the informal sector) and how they affect women's conditions with regard to their physical situation, health, sexuality, education, means of livelihood, and other aspects of their lives (Rowlands, 1998).

The concept of women's empowerment derives from the fact that power relations are embedded in the social relationships between men and women, and within institutions that affect women's lives - including households, the State, the market, 
and other domains of civil society. Women's empowerment thus implies a shift in these power relations in favour of women.

For the purpose of this study, empowerment is defined as a process by which people who have previously been denied or have not had the opportunity and the ability to make choices, obtain such an ability. This opportunity is especially important in strategic areas, such as livelihood, civil status, or maternity decisions (Kabeer, 1999; Kabeer et al., 2012). However, empowerment can also involve changes in the ability to make smaller but still meaningful choices in direct or indirect ways. Kabeer (1999) provides a useful framework for understanding empowerment, involving concepts of resources, agency and achievements (see Figure 1.1).

\section{Figure 1.1 Kabeer's empowerment framework}

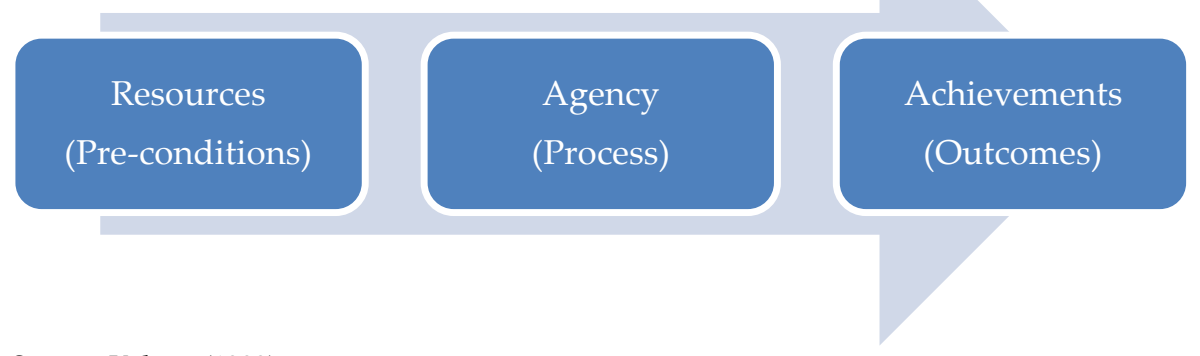

Source: Kabeer (1999)

People's access to resources (material, human and social) reflect rules and norms that give certain actors authority over others in determining the principles of distribution and exchange in different institutional arenas (the household, the market, and the community) (Kabeer, 1999). Agency is an individual's ability to define one's goals and act to try to achieve them. It can be manifested as decisionmaking, bargaining, negotiation, deception, manipulation, subversion and resistance, as well as cognitive processes of reflection and analysis. Achievements are outcomes, represented in studies of empowerment as indicators (Kabeer, 1999). Some of the most frequently used indicators of empowerment in the individual/ household level used in empirical studies are: domestic decision-making, access to or control over resources, and mobility/freedom of movement. Less frequently used indicators are: economic contribution to the household, freedom from violence and sense of self-worth, among others (Malhotra et al., 2002: 26). 
Using Kabeer's empowerment framework as a conceptual framework, this research will analyse what conditions of the CCTs under study (resources) help beneficiaries to achieve their empowerment (agency), measuring it through indicators such as labour market access, education, control over resources, domestic decision-making, and reproductive health (outcomes)-the themes addressed in chapters four through six. The study will also focus on the different effects that are achieved in diverse contexts, such as in different countries and in different communities within the same country (i.e. rural, semi-urban and urban).

This research examines the perceived consequences of two current programmes on the lives of the CCT beneficiaries living in the visited communities, particularly in the areas of labour market participation, intra-household decision-making, and feelings of self-worth. It also clarifies which factors need to be in place for CCTs to be effective in fostering empowerment. This research started with the general hypothesis, derived from the findings of policy literature that were discussed earlier and will be discussed in even more detail in chapter 2, that families that receive CCTs experience a change of intra-household dynamics that can foster women's empowerment, due to the fact, among others, that the beneficiaries have more control over resources and perceive a positive change in their status. However, the underlining assumption was that these dynamics can depend on the context (i.e. particular country, rural vs. urban communities, cultural issues, programme characteristics), hence the comparative research design.

The dependent variable of the research is women's empowerment. The main explanatory variables were the existence of conditional cash transfers, the specific characteristics of the CCTs (if they include educational talks or not, the transfers' amounts, etc.), the educational level of the beneficiary women, the community type (urban, semi-urban, rural), and beneficiaries' access to paid jobs. In order to measure empowerment five indicators were used, as shown in Box 1.1.

The objective of this research is to examine how women perceive the CCTs' receipt, how this perception is related to their experiences of empowerment, and how the empowerment can be fostered through conditional cash transfers. Therefore, a qualitative case study method (Yin, 2014) was employed and two cases of CCTs in Latin America were chosen. The information and data for this study were obtained through in-depth interviews with beneficiaries and non-beneficiaries in two countries -Mexico and Brazil. 
Box 1.1 Empowerment indicators

\begin{tabular}{|c|c|}
\hline Indicators & Measured by \\
\hline $\begin{array}{l}\text { Access to or control over } \\
\text { resources }\end{array}$ & $\begin{array}{l}\text { Control of cash, household income, assets, } \\
\text { welfare benefits, household budget, } \\
\text { participation in paid employment }\end{array}$ \\
\hline Domestic decision-making & $\begin{array}{l}\text { Finances, resource allocation, spending, } \\
\text { social and domestic matters, } \\
\text { child related issues (i.e. schooling, health) }\end{array}$ \\
\hline Mobility/ Freedom of movement & $\begin{array}{l}\text { Ability to go out of the house, whether alone } \\
\text { or accompanied }\end{array}$ \\
\hline Control over own body & $\begin{array}{l}\text { Ability to make childbearing decisions, use of } \\
\text { contraception, control over sexual relations }\end{array}$ \\
\hline Sense of self-worth & Positive feelings of self-worth and self-esteem \\
\hline
\end{tabular}

Source: Author's research based on Malhotra et al. (2002)

Given that Mexico and Brazil are rather large countries, the research focused on the Campeche state in Southeast Mexico and the Ceará state in Northeast Brazil. These states were selected since they both share similar poverty, development and inequality levels, and because of a lack of in-depth research on the impact of CCTs, especially in the gender area. The field research was undertaken in Campeche from April to June 2012, and in Ceará from October to December 2012. These timeframes provided enough time to get to know the communities, create trusting in-depth relationships with the beneficiaries, and conduct in-depth interviews.

We located the interviewees in the states of Campeche and Ceará. Within the states, communities were mapped according to rural, semi-urban and urban settings. One community was chosen from each classification. The treatment group consisted of beneficiary women living close to the poverty line. The control group consisted of women living close to the extreme poverty line but without receiving the transfers. The respondents consisted of ten women beneficiaries and ten women non-beneficiaries in three different communities (rural, semi-urban, and urban) in Mexico and Brazil. In total, 120 study participants were interviewed. Furthermore, secondary data on women's empowerment and conditional cash transfers were analysed, and quantitative and qualitative programme evaluations were reviewed.

\subsection{Case Studies}

The Oportunidades programme in Mexico and the Bolsa Família programme in Brazil were chosen as case studies. These programmes were selected since they share similar characteristics, such as duration of implementation, population covered, monitoring and evaluation systems in place, human capital approach, and 
a focus on gender. These government-funded programmes are also the leading CCTs in Latin America; therefore the analysis of their impact is relevant in order to extract policy lessons and recommendations for other countries in the region that would like to promote gender equality and poverty reduction.

\subsubsection{Oportunidades/Prospera in Mexico}

Oportunidades started on the $6^{\text {th }}$ of March 2002. The programme was based on the objective of increasing the capabilities of people living in extreme poverty (nutritional poverty), and of promoting their access to education, health, and better nutrition. Through targeted aid, its main goal is to build recipients' human capital, so they can break the intergenerational poverty cycle (Molyneux, 2006: 433). ${ }^{2}$

The targeted aid is provided in form of cash transfers (money for food and scholarships) and food transfers (nutritional supplements) directly to the female head of the family. The programme is also based on increasing scholarships given to children and young people going to school between the third year of elementary school and the last year of secondary school (high school) (children aged 9-18). These scholarships have a gender approach and give more money to girls than to boys after elementary school to compensate for the inequality of opportunities that girls face, in order to promote gender equality (approximately after age 12). ${ }^{3}$

The poverty reduction stream of Oportunidades can be linked to its emphasis on improving beneficiaries' nutrition, health and education standards. This is seen as a long-term effort to improve the human capital of the poor and the empowerment of poor women in order to raise their productivity and their income-generating potential, and in this fashion, to allow them to escape poverty through their own efforts in a sustainable way (Oportunidades, 2002). Since one of the key elements of Oportunidades is its co-responsibility or conditionality, beneficiaries must attend school and health check-ups. If the students do not attend at least $83 \%$ percent of the classes or if the mother and children do not attend the regular health check-ups in a given month, the transfers are stopped for that month, and they need to ask to reinstate them. The attendance rate is reported by teachers and doctors or nurses directly to Oportunidades officials (Oportunidades, 2003).

\footnotetext{
2 This "poverty cycle" is understood as a "vicious cycle" of under-nourishment, high morbidity and low education, which prevents the poor from developing their "productive potential," condemning them to living a life of poverty, generation after generation.

${ }^{3}$ Traditionally, families living in poverty in Brazil and Mexico prefer to support the education of their male children, because they think that they will need to work and support their own family some day. At the same time, they make girls stay at home and help with the domestic work based on the idea that they will eventually get married and will be supported by their husbands (ILSUND, 2009).
} 
The target of the programme are families living in rural, semi-rural and urban localities with a high degree of extreme poverty. The selection of the Oportunidades beneficiaries is determined by a three-step process: 1) localities are selected according to geographic targeting which considers their relative marginality, 2) extensive household surveys are conducted in the chosen localities to gather data on a variety of welfare indicators, and 3) the selected poorest families decide if they wish to be incorporated into the programme to receive the aid and accept some co-responsibilities. The co-responsibilities include the beneficiaries' obligation to ensure 1) their children's school attendance, 2) attendance at regular health check-ups, and 3) attendance at health seminars. After this process, the families receive aid for three years, and after that period, if they are still in extreme poverty, they can receive the aid for three more years (Oportunidades, 2002).

In general, the programme works based on transfers given to the selected beneficiaries in order to ensure the achievement of their basic capabilities in the short-term by allowing them to gain command of a minimum package of commodities and services (mainly food, health care and education). These transfers are:

- Monthly cash allowances given to the families of children attending from the third ( 8 years old) to the sixth grade (11 years old) of primary schools or from the first (12 years old) to the sixth grade (18 years old) of secondary school (high school). The amount of the scholarships increases as the education level advances and is higher for girls in secondary school, to reverse the gender bias in education. ${ }^{4}$ - Monthly cash allowances to contribute to the improvement of the families' food and energy consumption. ${ }^{5}$

- Nutrition supplements given to all children between 4 months and 2 years, to undernourished children between 2 and 5 years, and to pregnant and lactating women. ${ }^{6}$

These transfers are given by the government via debit card or cash hand-outs on a monthly basis to the female head of the family. There is also a maximum level of cash transfers that a single family is allowed to receive in order to avoid the creation of dependency on public aid and not to discourage the self-improvement

\footnotetext{
${ }^{4}$ The beneficiaries receive a debit card and have monthly transfers to their account, including the nutritional and educational components of the programme. They then can access the money through ATMs. In 2015, the transfers varied from 175MXN (9.2USD) per month for the third year of elementary school, to 1,120 MXN (59USD) per month for girls in high school or $980 \mathrm{MXN}$ (51.5USD) per month for boys in high school. For a full table of all transference values, please see Annex 4.

${ }^{5}$ This allowance is 683MXN (36USD) per month. For more details, please see Annex 4.

${ }^{6}$ This allowance is $120 \mathrm{MXN}$ (6.3USD) per month. For more details, please see Annex 4.
} 
efforts of the individuals. ${ }^{7}$ For families without children in high school the limit is 1,825 MXN (96 USD) per month, and for families with children in high school the limit is 2,945 MXN (155 USD) per month (Dávila, 2016).

Oportunidades allocates cash and food transfers directly to women since research suggests that resources handled by women have potentially more probabilities of positively impacting children's nutrition and health levels in a positive way than those handled by men. In addition, the gendered nature of the transfers is based on the idea that women's empowerment is fostered when they have more control over resources (Oportunidades, 2002; Adato, 2004: 350).

Following the gender approach, another key element of the programme is the participation of women in monthly educational seminars on different topics regarding health, nutrition, family planning and hygiene. These seminars are organised by the federal or local governments. The attendance at these seminars is one of the elements of the co-responsibility that families accept to follow in order to get the aid. These seminars help to educate women about their own health and their children's health. Other seminar topics, such as reproductive health, domestic violence, pregnancy, gender, and HIV/AIDS, help them to be more aware of their rights as women and of the need to be responsible for their own bodies and decisions.

\subsubsection{Bolsa Família in Brazil}

Bolsa Família is currently the largest CCT in the world, benefiting more than 14 million families living in extreme poverty - around 50 million people and almost $25 \%$ of the country's population (ILO, 2016). The programme started in October 2003 with the fusion of four previously existing conditional and unconditional cash transfers programmes of the Brazilian federal government: Bolsa Escola, a minimum-income grant related to primary education; Fome Zero and Bolsa Alimentação, which were income grants related to food security, the former unconditional and the latter conditional on health check-ups and immunization updates; and Vale Gás, a subsidy to help poor households buy cooking gas (Veras Soares et al., 2010: 174).

In 2014, total social expenditure in Brazil stood at just over 15\% of GDP (OECD, 2014). During 2006, social protection expenditure, including pensions, accounted for around $69 \%$ of total social spending, health $14 \%$ and education $6 \%$. Social

\footnotetext{
${ }^{7}$ From January 1st, 2017, the minimum wage in Mexico is 2,433MXN (128USD). As it can be noted, the amount a family with children in high school receives is 512MXN (27USD) more than the monthly minimum wage and thus an important contribution to the overall household income.
} 
assistance directed at the poorest remains a relatively small proportion of the total budget at some $7.5 \%$, with Bolsa Família accounting for two fifths of this amount, or $2.9 \%$ of total social expenditure (Hall, 2008). Overall, spending on CCTs grew less than $1 \%$ of the total social budget in 2001 to $2.9 \%$ in 2006 . Under President Lula da Silva, spending on Bolsa Família increased from $0.2 \%$ to $0.5 \%$ of GDP by 2005 (Lindert et al., 2007). Furthermore, according to the World Bank, Bolsa Família is not only the largest but also the best targeted CCT scheme in Latin America, with $73 \%$ of benefits reaching the poorest $20 \%$ of the population, and $94 \%$ falling within the lowest two quintiles (FAO, 2006).

The main objectives of Bolsa Família are: a) to reduce current poverty and inequality, by providing a minimum level of income for extremely poor families; $b$ ) to break the inter-generational transmission of poverty by conditioning these transfers on beneficiary compliance with human capital requirements (school attendance, vaccines, pre-natal visits); and c) to empower beneficiaries by linking them to complementary services (Lindert et al., 2007). Bolsa Família is focused on the accumulation of human capital and its most distinctive features are: the use of self-declared income instead of a proxy means method to assess eligibility, the existence of an unconditional transfer to extremely poor households regardless of the presence of children or pregnant women, and the decentralised nature of the application process, and of the monitoring of conditionalities, in which municipalities play an important role (Lindert et al., 2007).

The programme targets extremely poor and poor families at the national level through a combination of methods based on geographic and income per capitahousehold assessments. Geographic targeting is applied at the federal and municipal levels. Family eligibility is determined centrally based on household registry data collected locally and transmitted into a central database known as Cadastro Único. Bolsa Família provides cash transfers ranging from $\mathrm{R} \$ 35$ to $\mathrm{R} \$ 336$ (11-107 USD) per month to poor families, ${ }^{8}$ and these transfers are conditional upon proof of regular school attendance, children's vaccinations, visits to health clinics and other activities such as participation in nutrition and vocational training courses (Gazola, 2015). In case of the families not following the conditionalities (noncompliance), there are four consequences that become progressively more severe: 1) notification, 2) blockage, 3) suspension, and 4) cancellation. Upon initial noncompliance, the family receives a notification with no economic sanction. If they do not comply again during the next six months, they are blocked and their payment is blocked for 30 days. If in the next 6 months after the blockage the family does not comply again, they get suspended. The benefit is only cancelled if

\footnotetext{
${ }^{8}$ For 2017, the monthly minimum wage in Brazil is R $\$ 937$ (300USD). The highest transfers a family can get per month are around $33 \%$ of the national minimum wage.
} 
the family is in the suspension phase and the conditions of noncompliance continue for longer than a year (Gazola, 2015).

Another major objective of Bolsa Família is to target women and children directly to ensure that they can secure maximum benefit. To support this objective, cash transfers are channelled through the mothers of the households. Research shows that there have been subtle changes in household dynamics as a consequence (Lindert et al., 2007), but there is a need for more in-depth research. It is claimed that women have become more empowered through the increase in purchasing power gained and have thus experienced a strengthening of their authority in the household. Moreover, women participants consider that their citizenship rights have been strengthened as a result of having gone through the process of acquitting the official papers necessary to register for the programme and obtaining a Social Identification Number (Hall, 2008).

Both Oportunidades and Bolsa Família are governmental programmes based on transfers to mothers. These programmes are targeted to families living in extreme poverty provided that they follow certain conditionalities (school and health check-ups attendance). They operate based on the double objective of fighting poverty in the short-term through the cash transfers and of breaking the intergenerational poverty cycle by investing in human capital through school attendance and health check-ups. The only significant difference is that Oportunidades includes attendance at educational talks for the mothers as a conditionality, and Bolsa Família does not.

\subsection{Relevance, Scope and Limitations of the Research}

Since the early 2000s, extensive quantitative research has been undertaken regarding the impact of CCTs, especially in Mexico and Brazil (see for example, Adato and Roopnaraine, 2010; Behrman, 2010; Alzúa et al., 2013; De Brauw et al., 2014; Gazola, 2015; Dávila 2016). Nonetheless, in the area of women's empowerment there are still knowledge contributions to be made. While quantitative studies provide important information about the statistical impact of the programmes, in the case of women's empowerment, qualitative research helps us understand the perceptions of the women beneficiaries regarding their own processes and experiences. Money is imbued with social meaning (Zelizer, 1989; 1997), and money distributed by social programmes has meaning to recipients that affects the way in which recipients perceive and use the money (Sykes et al., 2015). The knowledge derived from this study can help further develop policy recommendations and conduct programme evaluations (Maxwell, 2005; Yin, 2014). 
While Oportunidades has been researched on health and education issues (see for example, Adato et al., 2000; Behrman and Parker, 2010), the qualitative effect of the programme on the areas of women's labour market participation, intra-household decision-making process, and feelings of self-worth has been under-researched. Adato et al. (2000) have explored the impact of Oportunidades on women's status and intra-household relations; however, the results are limited to some states and they comprise only some areas of decision-making processes. Evaluations undertaken so far have been limited, and researchers warn about the difficulty of disentangling actual areas of decision-making and about the results obtained so far, since women's answers to previous evaluations may reflect strategic choices about publicly presenting formal authority while not revealing the subtle and informal ways in which women actually make decisions or exercise influence. Adato and Roopnaraine (2010) suggest that a more in-depth research effort is needed to better understand these subtle patterns of decision-making and other manifestations of intra-household power relationships, in addition to the effect of Oportunidades on them, providing in this fashion a research niche for this research. In Brazil, quantitative evaluations are also extensive, and some research has been undertaken in the area of labour market participation (Samson et al., 2006; Gazola, 2015). Those evaluations show that the labour market participation rate of beneficiaries is significantly higher than of non-beneficiaries by $2.6 \%$, and this impact is gendered: the participation rate of beneficiary women is $4.3 \%$ higher than the men's rate. However, as in the case of Oportunidades, these results need to be researched in-depth and in other states and other areas of empowerment (Veras Soares et al., 2010).

The evaluation of Oportunidades and Bolsa Família with respect to qualitative issues regarding women's empowerment has not been extensive or systematised, thus providing a fertile ground for deeper investigation in this area. Nonetheless, this study is also limited in nature, since it involves qualitative methods, and its results are country-specific and community-specific. The data is not representative, not even for the states in which the data collection took place. In addition, since one of the objectives of this research was to discover the perceptions of the beneficiaries, some of the results might be biased or could be exaggerated by the people participating in the in-depth interviews. We attempted to avoid this bias by making very clear to the interviewees that we were independent researchers, with no association to the government, and without any control over their transfers. In this way, we assured them that their answers could not in any way affect their transfers. This is important since often beneficiaries fear the government will withdraw their benefits if they give answers that could show a negative effect of the programmes. Furthermore, according to Yin case studies aim for analytic generalisation, not statistical generalisation: "previously developed theory is used 
as a template with which to compare the empirical results of the case study" (2014: 38).

\subsection{Structure of the Dissertation}

The dissertation is structured in the following way: the second chapter provides a definition of conditional cash transfers and a review of prior literature on the feminization of poverty and on the link between social protection and gender. Furthermore, it provides an overview of the case studies used in this study: Oportunidades/Prospera in Mexico, and Bolsa Família in Brazil. Finally, it provides findings from previous academic research on the impact of CCTs in Latin America. The third chapter provides the theoretical framework of empowerment and discusses the research methods, explains the research design, methods of data collection, sample characteristics, data analysis methods, and the strengths and limitations of the methods. The fourth, fifth, and sixth chapters analyse and state the empirical findings of this study. The fourth chapter presents the link between CCTs and labour market participation. The fifth chapter evaluates the link between CCTs and intra-household decision-making power. The sixth chapter extents the analysis to CCTs and their effect on feelings of self-worth of the beneficiaries and provides details on the experiences that beneficiaries had regarding CCTs' receipt. The seventh and final chapter presents lessons learnt and discusses policy considerations and opportunities for future research. 


\section{Chapter 2. The Feminisation of Poverty and Conditional Cash Transfers}

\subsection{Introduction}

This chapter of the dissertation will provide insight into the following topics: 1) the concept of the feminisation of poverty, 2) social protection and gender, and 3) conditional cash transfers (CCTs) as a gendered social protection strategy. Furthermore, the specific cases of Oportunidades in Mexico and Bolsa Família in Brazil will be described, and findings from policy literature on the impacts of CCTs in Latin America will be presented.

According to Kabeer (2003), gender inequality is the most pervasive form of socioeconomic disparity worldwide. It has gained unprecedented visibility in the international development agenda since the mid-1990s (Rodenberg, 2004; Chant and McIlwaine, 2009). At the same time, the international development community has revived its efforts to reduce global poverty through the New Poverty Agenda (NPA), characterised by its broad concept of poverty and its emphasis on labourintensive growth, social services, and social protection (Maxwell, 2003; Baulch, 2006). The past decade has seen increasing attempts to merge these two objectives into common programmes, arguing that poverty alleviation and gender equality are mutually beneficial. In its Gender Action Plan (GAP), the World Bank thus described the promotion of gender equality as "smart economics" (2006: 2). Moreover, the growing strategic value of gender for poverty reduction has also pushed it into the macro-level domain through its incorporation into the Millennium Development Goals (MDGs), especially MDG 3 (Promote gender equality and empower women) and MDG 5 (Improve maternal health), and into Poverty Reduction Strategy Papers (PRSPs) as a cross-cutting issue (World Bank, 2003). The gender perspective is in addition incorporated in several of the United Nations' Sustainable Development Goals (SDGs) especially in the SDG 1 (End poverty in all its forms everywhere), SDG5 (Achieve gender equality and empower all women and girls), and SDG 10 (Reduced inequalities within and among countries). ${ }^{9}$

\footnotetext{
${ }^{9}$ www.un.org/sustainabledevelopment/sustainable-development-goals/
} 


\subsection{The Feminisation of Poverty, Gender and Social Protection}

\subsubsection{The Feminisation of Poverty}

The term feminisation of poverty was first coined in the 1970s by Diana Pearce (1978) but only became ingrained in the international development discourse in the mid1990s. The Fourth UN Conference on Women in Beijing in 1995 catapulted the term into common usage (UN, 1996). ${ }^{10}$ The Beijing Conference asserted that $70 \%$ of the world's poor were women. Furthermore, it adopted the eradication of the "persistent and increasing burden of poverty on women" as one of the critical areas of the Beijing Platform for Action (BPFA) (UN, 1996). Despite the frequently bemoaned lack of sufficient empirical evidence to back up this claim (Rodenberg, 2004; Chant, 2008), the assumption that women were disproportionately affected by poverty increased the visibility of gender needs and led to a joint effort of poverty alleviation and gender approaches to development.

Conceptually, such a joint effort was also supported by a paradigm shift in development in the late 1980s from neo-liberalism to the New Poverty Agenda (NPA) (Pieterse, 2001). A defining feature of the NPA is that its conceptualisation of poverty is more comprehensive than income and consumption poverty alone. Accordingly, the 1990 World Development Report defined poverty as "the inability to attain a minimal standard of living" (WB, 1990: 26), thereby combining a "consumption-based poverty measure with others, such as nutrition, life expectancy, under five mortality, and school enrolment rates" (WB, 1990: 26). The 1990 Human Development Report (HDR) went even further, including "political freedom, guaranteed human rights and personal self-respect" (UNDP, 1990: 1) as integral aspects of the human development process. ${ }^{11}$ Taken together, this comprehensive conceptualisation of poverty allowed a measurement and evaluation of vulnerability that exceeded material deprivation to incorporate access to social services and "freedom from bias by gender and age" (Lipton and Maxwell, 1992: 10). In this broad definition, gender inequality almost became a form of poverty in itself, which in turn would make greater gender equality a form of poverty alleviation.

\footnotetext{
10 The typical definitions and measurements of women's poverty in the literature may be based on the conventional measures of household income and consumption, or on qualitative and quantitative measures of "entitlements" and "capabilities." The latter are captured by social indicators such as literacy, life expectancy, primary and secondary school enrolments, access to health care, maternity mortality rates, access to land or employment, wage differentials, time-use, average age at first marriage, percentage of teenage girls ever married or pregnant, fertility rates, sex ratio, and the extent of prostitution (UN, 1996).

11 The UNDP defines "human development" as the process of enlarging people's choices and opportunities through long life, health, and education (1997).
} 
Even more important for the convergence of gender equality and poverty reduction efforts in practical terms are their conjectured synergies (Rodenberg, 2004; Chant, 2008). The rhetoric of this win-win formula was exemplified by the Asian Development Bank's (ADB) claim that the "overarching goal of poverty reduction is closely linked to improving the status of women, since equity especially gender equity- is [...] an essential factor in transforming growth to development and reducing poverty" (2002: 136). The popularity of this link in the international development agenda led to a virtual "feminisation" of anti-poverty programmes (Chant, 2007: 5), evidenced in programmes to increase women's human capital ${ }^{12}$ that provide access to micro-credits or targeted support through conditional cash transfer programmes (CCTs), such as Oportunidades/Prospera in Mexico or Bolsa Família in Brazil.

Despite these achievements in the discourse for gender equality and poverty fighting, the criticism is often voiced that in its translation into policy the "feminisation of poverty" approach represents a disjuncture with holistic concepts of both gender and poverty (see for example Chant, 2008). As it links poverty to women rather than to gender relations, women are again portrayed as victims of unequal development rather than unequal power relations (Rodenberg, 2004; Chant and McIlwaine, 2009). Moreover, according to Chant (2008), the feminisation of poverty gives income poverty precedence over other forms of deprivation such as powerlessness or time poverty, which are disproportionately encountered by women. This lack of multidimensionality makes it harder to assess the gendered dimensions of poverty, which may also lead to disregard the additional burdens that anti-poverty programmes can put on women. Moreover, the narrow focus on material poverty weakens the conceptual link and thus the potential synergies between gender equality and poverty reduction. Consequently, critics like Mayoux (2006) have argued that the incorporation of gender issues into material-focused poverty reduction measures risks "evaporation" into merely using women's time and resources for programme efficiency or community development.

However, it could be argued that the instrumental use of gender within antipoverty approaches is better than the earlier gender blindness, as it makes economic development more equitable. Even critics concede that the feminisation of poverty concept has been beneficial "insofar as it has made women visible in

\footnotetext{
12 The human capital theory was announced in 1960 by Theodore Schultz and refers to knowledge, skills, health or values that people possess or have access to (Blaug, 1976). Education, training, and health are among the most important investments in human capital. In addition, human capital is a collection of traits: the knowledge, talents, skills, abilities, experience, and training possessed individually and collectively by individuals in a population. These resources represent a form of wealth which can be directed to accomplish personal or common goals.
} 
poverty discourses and raised their profile in anti-poverty initiatives" (Chant, 2008: 188). Nevertheless, in the light of the international community's commitment to create greater gender equality and empower women (for example MDG 3 and SDG 5), it is important to look at investments in women and girls as more than just a "business case" (WB, 2006: 2).

The lack of women's economic resources constitutes a substantial difference between women's and men's life experiences. In situations of extreme poverty, in which survival options are already limited due to the lack of economic resources, any other restriction posed on individual agency exacerbates social and economic marginalisation. In this way, the manner in which women experience poverty is often more arduous and complex than the manner in which men experience poverty (Chant, 2010).

Buvinic and Gupta (1994) addressed the issue of female headship as an indicator of poverty through an analysis of 65 studies on countries in Latin America, the Caribbean, Asia, and sub-Saharan Africa, carried out between the 1980s and early 1990s. Sixty-one of the studies examined the relationship of female headship to poverty, and the majority concluded that female-headed households are overrepresented among the poor. There were, of course, exceptions. Data from the Philippines showed that female-headed households (FHHs) were relatively welloff when compared with Thailand, which may be related to the prevalence of the extended family that shelters subfamilies formed by single mothers and children (Buvinic and Gupta, 1994). In Argentina, households headed by widowed and divorced women seemed to be relatively well-off. But in general, FHHs tended to be poorer because of their higher dependency burden, because of the genderrelated economic gaps, and because of the greater time and mobility constraints women face (ECLAC, 1995: 70). The studies discussed by Buvinic and Gupta also found that children in FHHs work more often than children in other households, with potentially negative long-term implications for their welfare.

Table 2.1 shows how this phenomenon is substantiated by data from Latin America (CEPAL, 2002), where women-headed households tend to be overrepresented among the extreme poor. ${ }^{13}$ Data indicates that female-headed households have fewer possibilities to obtain economic resources.

\footnotetext{
${ }^{13}$ Extreme poverty was originally defined by the United Nations in 1995 as a condition characterised by severe deprivation of basic human needs, including food, safe drinking water, sanitation facilities, health, shelter, education and information. Such condition depends not only on income but also on access to services (UN, 1995). In 2008, extreme poverty referred to earning below the international poverty line of 1.25 USD per day. In 2015, the World Bank updated the international poverty line to 1.90USD per day (http://www.worldbank.org/en/research/brief/policy-research-note-03-endingextreme-poverty-and-sharing-prosperity-progress-and-policies).
} 
below poverty line $(\%)$

\begin{tabular}{|c|c|c|c|c|}
\hline Country & Area & Male & Female & $\begin{array}{l}\text { Women per } 100 \\
\text { men below poverty } \\
\text { line }\end{array}$ \\
\hline Argentina & Urban & 23.8 & 23.6 & 99.3 \\
\hline \multirow[t]{2}{*}{ Bolivia } & Urban & 48.6 & 48.2 & 101.4 \\
\hline & Rural & 79.4 & 81.6 & 102.8 \\
\hline \multirow[t]{2}{*}{ Brazil } & Urban & 33.0 & 32.6 & 99.5 \\
\hline & Rural & 54.8 & 55.6 & 101.6 \\
\hline \multirow{2}{*}{ Chile } & Urban & 20.6 & 20.6 & 101.0 \\
\hline & Rural & 26.4 & 28.8 & 109.1 \\
\hline \multirow[t]{2}{*}{ Costa Rica } & Urban & 16.8 & 19.2 & 114.4 \\
\hline & Rural & 20.8 & 23.8 & 114.5 \\
\hline \multirow{2}{*}{$\begin{array}{l}\text { Dominican } \\
\text { Republic }\end{array}$} & Urban & 33.9 & 36.9 & 110.2 \\
\hline & Rural & 37.7 & 43.3 & 115.0 \\
\hline Ecuador & Urban & 63.1 & 63.3 & 102.8 \\
\hline \multirow[t]{2}{*}{ El Salvador } & Urban & 38.1 & 39.0 & 101.3 \\
\hline & Rural & 64.9 & 65.4 & 100.8 \\
\hline \multirow[t]{2}{*}{ Guatemala } & Urban & 45.7 & 45.4 & 101.0 \\
\hline & Rural & 69.8 & 70.0 & 100.4 \\
\hline \multirow[t]{2}{*}{ Honduras } & Urban & 66.6 & 65.4 & 99.3 \\
\hline & Rural & 81.0 & 81.5 & 100.8 \\
\hline \multirow[t]{2}{*}{ Mexico } & Urban & 38.7 & 38.7 & 100 \\
\hline & Rural & 58.3 & 58.6 & 101.6 \\
\hline \multirow[t]{2}{*}{ Nicaragua } & Urban & 63.4 & 64.5 & 101.7 \\
\hline & Rural & 77.4 & 76.6 & 99.0 \\
\hline \multirow[t]{2}{*}{ Panama } & Urban & 25.8 & 26.6 & 103.1 \\
\hline & Rural & 40.4 & 43.6 & 107.9 \\
\hline \multirow[t]{2}{*}{ Paraguay } & Urban & 49.7 & 47.4 & 97.1 \\
\hline & Rural & 73.2 & 74.4 & 101.9 \\
\hline Uruguay & Urban & 9.7 & 9.4 & 97.3 \\
\hline Venezuela & Total & 48.6 & 50.0 & 104.4 \\
\hline
\end{tabular}

Sources: CEPAL (2002)

In Brazil, Chile and Mexico, where gender inequalities are pronounced in labour markets, and where neo-liberal reforms led to increases in poverty, research found that poor women were worse off than men in rural areas, and households maintained by women were poorer than those maintained by men (CEPAL, 2002). Women's economic activity remains low and is also concentrated in low-paid informal occupations rather than in technical and professional employment. Despite advances towards gender equality in education, the gendered salary gap continues to be significant (i.e. women's wages are $79 \%$ of men's wages in the 
Central American Isthmus), even for those with the same level of education. Besides prejudice and discrimination, one reason is the reproductive role of women. Fertility rates have decreased in the region; for example, from 6.5 to 4.6 in Guatemala between 1965 and 2005 but remain a challenge particularly for marginalised groups, such as the rural indigenous poor (Barbieri-Masini, 2009; Coates, 2010).

The poverty that women endure has many dimensions that interact with each other. The ways in which gender norms and values, divisions of assets, work and responsibility and relations of power and control function make the experience of poverty a profoundly gendered one. These gendered experiences include first, different experiences of poverty for girls versus boys, and women versus men within the household; second, different household responses to resource limitations depending on the gender of the person being affected; third, the presence of deprivation for some members along certain dimensions even in nonpoor and well-off households; and fourth, the differential impact of the design and implementation of anti-poverty policies and programmes. Understanding how gender relations work to define the experience of programmes requires focusing on who gets, or has access to, resources; how roles and relationships of work, responsibilities, cooperation, sharing or conflict define both women's and men's living and working conditions within households; how structures and programmes of the state and other actors (private sector, civil society) reinforce or transform those roles and relationships; and how normative frameworks affecting differential entitlements and responsibilities are challenged or reinforced by policies and programmes (Sen, 2010).

Recent developments in the study of multidimensional poverty pay attention to the multidimensionality of poverty for households (Alkire and Foster, 2007) and for children (De Neubourg et al., 2012a, 2012b, 2014), but a multidimensional analysis of female poverty is only being developed in 2017 (Ramful and De Neubourg, 2017).

The fact that resources including both tangible productive assets such as land, and intangible resources like knowledge and networks, are overwhelmingly distributed in favour of men is well-known. Equally valid is the proposition that girls and women bear greater work burdens and responsibility for the "care economy" -the usually unpaid work that goes into the care of human beings. This is well evidenced through a large number of studies of time-use and qualitative surveys (see Molyneux, 2007a; Chant, 2008; Sen, 2010; Klasen et al., 2015). The care work undertaken by women and girls in the poorest households tends to be extremely time- and drudgery-intensive, but it is crucial to household members' ability to sustain basic daily consumption. As a result, it drastically limits women's 
choice of compatible income-earning opportunities, their ability to take time off for government programmes, social exchanges or minimal leisure, and their possibilities for acknowledging their own needs for rest, recuperation or healthcare (Chant, 2010).

The study of the gendered impact of poverty not only distinguishes between women and men, but also differentiates how care-work burdens and responsibilities are experienced by different women. Evidence suggests that, where such burdens are reinforced by strong gender norms that define a "good" woman as selfless and self-sacrificing, poor women (and to a lesser extent, those who are better-off) are likely to receive much less acknowledgement of or attention to their needs for nutrition or healthcare, not only by other family members but even by themselves (Sen, 2008; Klasen et al., 2015).

Poor households respond to their poverty in a variety of ways. Some of these responses are gendered, although with certain variations across cultural and economic contexts. While men may take on more income-generating work, women often face difficult time allocation choices between increased income-generating work versus substitution of home-made or freely gathered consumption items (food, clothing, fuel) based on increased unpaid work and time. These tensions are often resolved by sacrificing leisure, playtime, or education of daughters, who are expected to take on additional care-work, including kitchen tasks, foraging, and looking after siblings, as well as other responsibilities. Another gendered response is desertion or abandonment of families -a strategy often used by poor men to escape the responsibilities of contributing to household consumption, particularly when their partners or spouses become pregnant. A third phenomenon, noted particularly in South Asia, is selective education and healthcare, with sharply lower entitlements for women and girls relative to men and boys. Such differentials in entitlements are reinforced through gendered norms and values that permeate across the economic spectrum. Hence, while they tend to be lower in intensity for better-off households, they do not completely disappear (Sen, 2010).

\subsubsection{Social Protection and Gender}

Social protection is a relatively new policy approach with the objective of integrating concerns about social security and poverty reduction into an integrated framework (Kabeer, 2008). Commonly, the social protection agenda has been presented by the international development community in terms of categories of poor, excluded and vulnerable social groups, differentiated by age, health status, and relationship to formal labour markets (Thakur et al., 2009). Although some policies are targeted primarily at female-headed households, gender is rarely used as a special category with which to understand poor people's exposure to risk and 
vulnerability, and to design social protection measures accordingly (Alkire and Foster, 2007; Thakur et al., 2009; Chant, 2010).

Progress on gender equality, however, is recognised as a critical factor in achieving the SDGs. Women and men face different constraints and barriers that can limit opportunities for women and girls. According to Kabeer's (2008) typology, these constraints fall into three categories:

a) Gender-specific (i.e. societal norms and practices that apply to women or men by virtue of their gender);

b) Gender-intensified (i.e. inequalities between household members reflecting norms and customs on the discrimination of food, health care, access to property, etc.);

c) Gender-imposed (i.e. forms of gender disadvantage that reflect discrimination in the wider public domain).

Such constraints mean that girls and women are disproportionately represented among the extreme poor in many parts of the world (DFID, 2005a). They not only limit women's access to the labour market but also often confine working women to more poorly remunerated, more casual and more insecure forms of waged-and self-employment, particularly in the informal economy, without access to social protection. These factors underline the need for greater understanding about the rationale, and policy and programme implications of a gendered approach to social protection (Thakur et al., 2009).

The higher levels of vulnerability often faced by girls affect future productivity. They are more likely than boys to be kept out of school for domestic chores and home-based work, and early marriage and childbearing may further restrict their education, skills development and opportunities (see Devereux, 2002; DFID, 2005b; Barrientos, 2008). Women's opportunities are also limited by their primary responsibility for childcare and domestic work, cultural restrictions on their public mobility in some regions of the world, and the gender segmentation of employment opportunities. While their market contributions have become more important within household livelihood strategies, women are still concentrated in informal and labour intensive work, often face particular risks and vulnerabilities (i.e. health risks, interrupted and insecure employment), and they are less likely to be able to save or contribute to pensions (Thakur et al., 2009; Devereux and Solórzano, 2016).

In looking at the relationship between social transfers and economic growth, the gender of cash transfer beneficiaries can make an overall difference to the effectiveness with which it stimulates investment and facilitates more efficient resource allocation within the household. Well-designed policies that take into 
account the possibility of both positive and negative synergies between women's and children's welfare and recognise the barriers to women's progress in the labour market have strong potential to contribute to the wider goals of economic growth and human development (Barrientos, 2008).

\subsubsection{Women and the Gender Gap in Poverty}

From the 1990s onwards, the feminisation of poverty has been heavily discussed among economists (see, for example, Chant, 2008). Reasons for an explicitly gender-related approach are, among others, the observed increase of femaleheaded households (Moghadam, 2005; Klasen et al., 2015) as well as the belief that especially these households suffer from the burden of poverty and vulnerability (Buvinic and Gupta, 1997).

The literature on the disadvantages of women in developing countries can broadly be grouped into two strands: one which focuses on gender related differences (i.e. on differences between men and women, in general), and another one which concentrates on the comparison of male and female-headed households.

Among disadvantages for women in developing countries, the lack of access to markets stands out. First, in many developing countries, women have no access to land. Especially for rural households that depend on agriculture, land is one of the most important productive assets. Empirical evidence indicates that access to land is positively associated with higher incomes (World Bank, 2006). However, land tends to be distributed unevenly between men and women, with the former owning by far the largest share. Deere et al. (2012), for example, find that in some Latin American countries, the male share of owners of farmland ranges between $70 \%$ and $90 \%$. Moreover, female land owners commonly possess less land than their male counterparts. Underlying factors causing this inequality include inheritance and land titling laws in favour of men.

Second, women suffer from a limited access to formal credit markets. The problem is not so much that they are rejected for loans or are charged higher interest rates but that they do not tend to apply for loans because they do not dispose of collateral such as land or other property. Husbands or other male relatives may help getting credit by co-signing loans. However, this support is by no means a matter of course and is much harder to obtain by female-headed households. Third, insurance markets in rural areas of developing countries are -if existing at all- often hardly functioning. While both men and women are affected by such a market failure, the latter are likely to suffer more from it in the absence of a formal pension system and equal property rights. Furthermore, women usually have very 
limited possibilities to contract health insurance and may get access only through spouses employed in formal sector jobs (World Bank, 2001).

Fourth, women have less access to the labour market than men. Gender discrimination in the labour market is a common phenomenon in both developed and developing countries. But while discrimination in the former is reflected in differential wage rates, discrimination in the latter is associated with differential access to wage employment (Collier, 1994). Often this is caused by cultural factors such as norms and traditions and not necessarily by gender discrimination in the labour market itself. Already during childhood, when households invest less in schooling of girls, unequal labour opportunities are predetermined (WB, 2001). Later on, the work of women is frequently confined to the home because of the "social stigma" against (manual) labour outside the household (Goldin, 1994). Furthermore, there is another reason why women face limited access to the labour market: full-time jobs during set hours effectively exclude mothers from employment whereby their confinement to domestic work is perpetuated (WB, 2001). Finally, even if female shares in formal employment are high -as is predominantly the case in East and Southeast Asia- women are paid significantly less than men. This wage differential cannot be explained by worker characteristics such as education and experience (see Horace and Oaxaca, 2001; Klasen, 2006).

In addition to the generally gender-related economic gap, there are disadvantages particular to female-headed households. Most strikingly, households led by women carry a "double day burden" if their heads have to handle domestic work and the role of breadwinner simultaneously (Moghadam, 2005). Consequently, these women suffer from more pronounced time and mobility constraints than others, which in turn possibly impacts negatively on income of their households (Buvinic and Gupta, 1997; Lundberg and Rose, 2007; Hasan, 2010).

Lastly, female-headed households often lack support from both social networks and the state. For example, Bibars (2001) finds that for women in Egypt there is no institutional alternative to a male provider. Chant (2008) underlines that female heads may lack ties with ex-partners' relatives, as well as with their own families and communities. However, female household heads who are married and whose husband migrated may receive adequate remittances preventing them from experiencing destitution (Buvinic and Gupta, 1997, Klasen et al., 2015). 


\subsection{Conditional Cash Transfers Programmes (CCTs) as a Gendered Approach to Social Protection}

CCTs are based on the assumption that households do not invest sufficiently in their children's human capital and are therefore caught in "a vicious cycle of intergenerational transmission of poverty" (Molyneux, 2006: 433). Therefore, CCTs make the transfer of grants to extreme poor households or individuals -generally to the mothers, therefore the gendered approach- conditional on pre-specified human capital investments. In this manner, they combine short-term relief of consumption poverty with social services and investments that promote sustainable poverty reduction through structural changes. CCTs, along with microcredit schemes, are among the policy instruments currently most favoured by governments to tackle poverty (Molyneux, 2006). They are generally successful in increasing children's school attendance, and improving nutritional and health indicators (Adato and Hoddinott, 2010; Dávila, 2016). They are innovative in giving transfers directly to mothers, along with the obligation for complying with co-responsibilities. In addition to ensuring children's regular attendance at school and health clinics, mothers are required to attend talks on health care and nutrition (Sedesol, 2002a).

Mothers centrality to the CCT programmes is understood to be key to the programmes' success, as women can generally be relied upon to fulfil their responsibilities to their children and to spend the money they are given in accordance with their children's needs. CCTs bring some gains to women: as a result of receiving and managing the transfer many report enjoying an increased family and neighbourhood status and exercising more control over household expenditure (Escobar Latapí and De la Rocha, 2009). By increasing their resources, they increase their status and exercise more control, which leads to more power and therefore an empowerment process. These benefits are often the basis for the claim that CCTs "empower" women. Such claims are, however, seldom examined in any depth or detail, nor is the design of cash transfer programmes or the impact upon gender relations within the household given much consideration in most evaluations (Molyneux, 2007a).

Individual studies evaluating CCTs indicate that social protection can help address gender imbalances in access to education, health and food. However, there is currently a lack of reliable data on the overall empowerment effects (Molyneux, 2007b). Recent studies suggest a mix of possible positive and negative effects. Research from the Oportunidades programme in Mexico shows that giving cash only to women increases their decision-making role in household expenditures and their financial security, self-esteem and social status (Adato and Roopnaraine, 2010). A gender audit of the Bolsa Família programme in Brazil found that 
women's domestic status increased because the income received was regular compared with other household members, whose jobs and wages were uncertain (Suarez et al., 2006).

On the other hand, some argue that conditional cash transfers reinforce gender stereotypes. Many programmes assume that women are available to carry out the care-related obligations associated with conditional transfers without consideration of their breadwinning responsibilities or need for paid work and neglect any recognition of fathering responsibilities. Some Brazilian experts have commented that Bolsa Família utilises the "culture of mothering" without necessarily supporting the personal progress of women as active citizens (OECD, 2009; Thakur et al., 2009).

\subsubsection{CCT Case Study 1: Oportunidades/Prospera in Mexico}

In 1994, Ernesto Zedillo from the PRI ${ }^{14}$ was elected president in Mexico. The beginning of his administration was marked by a terrible economic crisis that started in December 1994. With this economic turmoil, Zedillo did not want to be related to the ex-president Carlos Salinas, ${ }^{15}$ or to his social and economic policies. Therefore, the Programa Nacional de Solidaridad (Pronasol) ${ }^{16}$ was slowly dismantled, and during the first three years of Zedillo's government, there was a vacuum of social policy, which was deepened by a governmental controversy (Kurtz, 2005).

The governmental controversy arose due to conflicting social policy approaches by the two main groups of the political elite. The first group, the "social reformers," wanted to continue the universalistic social policy approach that had started with Pronasol, while the second one, the "technocrats," wanted to implement a targeted way of poverty alleviation, based on the ideas of improving human capital in order

\footnotetext{
${ }_{14}$ Partido Revolucionario Institucional (Revolutionary Institutional Party).

${ }^{15}$ The election of Salinas in 1988 marked the ascendance of the technocratic wing of the ruling Mexican political party, Partido Revolucionario Institucional (PRI), which was in power for 71 years, from 1929 to 2000 .

16 President Salinas's antipoverty strategy, embodied in the Programa Nacional de Solidaridad, Pronasol, (National Programme for Solidarity), was designed to make social spending compatible with neo-liberal adjustment strategies. Pronasol reoriented Mexican antipoverty policy into highly targeted forms on the consumption side and, on the production side, market failure corrections, social capital formation, and microenterprise finance. The participation of local social groups in the design and execution of projects was a key aspect of Pronasol, and the basic mode of operation was through the local solidarity committees (Kurtz, 2005: 154). Mainly, this programme accepted that the state should intervene to some degree in the economy to help the most disadvantaged social classes to survive the economic structural adjustment, and it was mainly based on the idea of social capital, of subsidies on the demand side, of community participation in the creation of public infrastructure, and of giving the poorest people a social welfare package including basic health, nutrition, education and housing.
} 
to help individuals get out of poverty. Since this debate was at the core of the political elite, social policy implementation stopped for three years, and there was a rupture in the Secretaría de Desarrollo Social (Sedesol) ${ }^{17}$ until 1997, when the Programa de Educación, Salud y Alimentación -Progresa- was created (Valencia and Aguirre, 1998).

The main objective of Progresa was to increase the basic capabilities of families living in extreme poverty, through the promotion of education, health and nutrition, and to support their access to goods and services that could help them develop skills and break the intergenerational poverty circle. Progresa started the era of targeted poverty alleviation programmes in Mexico. It worked based on the elements of 1) targeted cash and food transfers delivered to mothers in extreme rural poverty, 2) a human capital approach, and 3) co-responsibility. ${ }^{18}$ This new approach in the anti-poverty agenda developed because of internal problems encountered during Pronasol, ${ }^{19}$ and changes in the international anti-poverty agenda, which switched from a universalistic approach to a targeted one (conditional cash transfer programmes). ${ }^{20}$

Progresa was a transfer-based poverty alleviation programme which worked by giving nutritional and educative support and cash transfers. The mothers of families in extreme rural poverty could receive nutritional supplements for their children, money to buy food, and scholarships for the education of each of their children attending school between the third level of elementary school and the third year of junior high school. ${ }^{21}$ The scholarships received would be larger for girls between the first and the third year of junior high to compensate for the gender inequalities of the country. However, in order to receive this aid, the beneficiaries needed to commit themselves to attending regular health check-ups

\footnotetext{
17 Social Development Ministry.

18 The element of co-responsibility in the Progresa and Oportunidades Programmes means that in order to get the benefits of social programmes, families in extreme poverty need to follow certain requirements imposed by the government; for example, they need to send all their children to school, take them to regular nutrition and health check-ups and participate in educational health seminars held by the local health centres.

${ }^{19}$ It has been argued that President Salinas used Pronasol as a key political strategy. Resources were to be targeted not only by the degree of poverty, but also to areas of high political opposition. In this way, the president sought to legitimise the government and to dissipate the opposition threat (Kurtz, 2005).

${ }^{20}$ In ideological terms, a commitment to neo-liberalism meant a rethinking of state-society relations that would result in changes to the regime of social provision. As efficiency criteria began to govern state action and an emphasis on market price signals became axiomatic, antipoverty policies were pushed towards a more targeted and means-tested direction. It has also been suggested that the creation of this neo-liberal form of social welfare was, in the Mexican case, largely an external imposition, linked to the implementation of liberal economic policies and propelled politically by the IMF and the WB (Kurtz, 2005).

${ }^{21}$ The age range of the children benefited by the programme was between 9 and 15 years old.
} 
and to sending all their children to school. If these co-responsibilities were not adhered to, the family would stop receiving the support of the programme (Valencia and Aguirre, 1998). ${ }^{22}$

In 2000, Vicente Fox, from the PAN, ${ }^{23}$ became the first elected president from an opposition party after 71 years of PRI's rule. This situation meant an immense change in Mexican state politics, and controversy arose about whether or not the previous social policy approach would be continued. From 2000 to 2002, Progresa kept working regularly. In 2002, the Programa de Desarrollo Humano Oportunidades (Oportunidades) was created by the Fox's administration. Oportunidades used the same ideological and pragmatic basis as Progresa, but the name changed to emphasise the change of administration.

Oportunidades was based on the ideas that targeted aid produces better results than a universal provision of aid, that gender inequality needs to be addressed, and that investment in human capital ${ }^{24}$ is the best way to help poor people overcome poverty, hand in hand with the overall economic development of the country. Alongside these guidelines, the Mexican government developed a new technical definition of poverty ${ }^{25}$ in an effort to design better antipoverty measures. This poverty definition included three poverty lines based on the income level of the population: nutritional poverty (pobreza alimentaria), capabilities poverty (pobreza de capacidades) and conditions poverty (pobreza de patrimonio). Nutritional poverty ${ }^{26}$ was when the household's income was not enough to cover the nutritional needs of the members of the family, and it was equivalent to 1.6 USD per person per day in rural areas and 2.2 USD per person per day in urban areas. $^{27}$ In 2000, $24.2 \%$ of the total population of the country lived below this

\footnotetext{
22 These co-responsibilities were surveilled with the help of teachers, doctors, and workers of the Progresa programme.

${ }_{23}$ Partido Acción Nacional (Party for National Action)

24 The human capital approach argues that if individuals have better education, health and nutrition, they will be better prepared to engage with the market economy, by getting better paid jobs and therefore overcoming poverty.

${ }^{25}$ This definition of poverty was created in 2001 by the Comité Técnico para la Medición de la Pobreza (Technical Committee for the Measurement of Poverty) in order to provide official poverty data that could be used as a guideline to plan the social policy, design social programmes and evaluate their efficacy.

${ }^{26}$ The index of nutritional poverty is measured by the ability of the household to buy a "canasta alimentaria básica" (basic nutritional basket), which includes cereals, meat, milk, eggs, oil, potatoes, beans, vegetables and fruits. This basic basket is set by the Encuesta Nacional de Ingresos y Gastos de los Hogares (ENIGH), which is implemented by the Instituto Nacional de Estadística, Geografía e Informática (INEGI).

${ }^{27}$ The poverty line amounts refer to the amount of USD per person per day. The amounts given here are from 2000 .
} 
poverty line (Sedesol, 2003). By 2014, it had reduced to $9.5 \%$ of the national population (Coneval, 2014).

The capabilities poverty was when the household's income was not enough to cover an individual's nutritional, educational and health needs, and it was equivalent to 2 USD per person per day in rural areas and 2.6 USD per person per day in urban areas. In 2000, 31.9\% of the population lived below the capabilities poverty line. Finally, the conditions poverty was when the household's income was not enough to cover the nutritional, educational and health needs and the basic consumption of clothing, housing and public transportation. This meant less than 3 USD per person per day in rural areas and 4.4 USD per person per day in urban areas. In 2000, 53.7\% (approx. 53 million of people) of the population lived in this kind of poverty (Sedesol, 2003). By 2014, 46.2\% (approx. 55.3 millions) of the national population lived under this poverty line (Coneval, 2014). ${ }^{28}$

Oportunidades started to work on March $6^{\text {th }}, 2002$, based on the objectives of increasing, by means of targeted aid, the capabilities of people living in extreme poverty (nutritional poverty), and of promoting their access to education, health, and better nutrition, with the main goal of building their human capital so they could break the intergenerational poverty cycle. ${ }^{29}$ The targeted aid is given in form of cash transfers (money for food and scholarships) and food transfers (nutritional supplements) directly to the mother of the family. The programme is also based on increasing scholarships given to children and young people going to school between the third year of elementary school and the last year of secondary school (high school). Following Progresa's guidelines, these scholarships have a gender approach and allocate more money to girls than to boys after elementary school to compensate for the inequality of opportunities that girls face in order to promote gender equality. ${ }^{30}$

The poverty reduction stream of Oportunidades can be linked to its emphasis on improving beneficiaries' nutrition, health and education standards. This is seen as a long-term effort to improve the human capital of the poor -and the empowerment of poor women- in order to raise their productivity and their

\footnotetext{
${ }^{28} \mathrm{http}: / /$ www.coneval.org.mx/Medicion/MP/PublishingImages/Pobreza_2014.jpg

29 This "poverty cycle" is understood as a "vicious cycle" of under-nourishment, high morbidity and low education, which prevents the poor from developing their "productive potential" thus condemning them to living a life of poverty, generation after generation.

30 Traditionally, families living in poverty prefer to support the education of their male children, because they think that they will need to work and support their own family someday. At the same time, they make girls stay at home and help with the domestic work, based on the idea that they will eventually get married and will be supported by their husbands.
} 
income-generating potential, and in this manner, to allow them escape poverty through their own efforts in a sustainable way.

The target population of the programme are families living in rural, semi-rural and urban localities with a high degree of extreme poverty. The selection of the Oportunidades beneficiaries is determined by a three-step process undertaken by the Social Development Ministry (SEDESOL): 1) localities are selected according to geographic targeting which considers their relative marginality, 2) extensive household surveys are conducted in the chosen localities to gather data on a variety of welfare indicators, and 3) the selected poorest families decide whether they wish to be incorporated into the programme to receive the aid and accept to follow some co-responsibilities. The co-responsibilities include the beneficiaries' obligation to ensure 1) their children's school attendance, 2) attendance at regular health check-ups, and 3) attendance at health and education seminars. In general, the programme works based on transfers (see Box 2.1) given to the selected beneficiaries in order to ensure the achievement of their basic capabilities in the short-term by allowing them to gain command of a minimum package of commodities and services (mainly food, health care and education).

\section{Box 2.1 Oportunidades' transfers}

1) Monthly cash allowances given to the families of children attending from the third to the sixth grade of primary schools or from the first to the sixth grade of secondary school (9-18 years old). The amount of the scholarships increases as the education level advances and is higher for girls in secondary school, to reverse the gender bias in education.

2) Monthly cash allowances to contribute to the improvement of the families' food and energy consumption.

3) Nutrition supplements given to all children between 4 months and 2 years, to undernourished children between 2 and 5 years, and to pregnant and lactating women.

4) Monthly cash allowance called "Vivir Mejor" ("Living Better") for extra expenses.

Source: Author's adaptation of information from SEDESOL (2003)

These transfers are provided on a monthly basis to the mother of the family as a way to avoid the gender bias of intra-household distribution of food and other commodities. There is also a maximum level of cash transfers that a single family is allowed to receive in order to avoid the creation of dependency on public aid and not to discourage the self-improvement efforts of the recipients of the transfer. ${ }^{31}$

\footnotetext{
31 The transfers vary from 175MXN (9.2USD) per month for the third year to elementary school to 1,120 MXN (59USD) per month for girls in high school or 980 MXN (51.5USD) per month for boys in high school. For families without children in high school the limit is 1,825 MXN (90 USD) per month, and for families with children in high school the limit is 2,945 MXN (155 USD) per month. From January 1st, 2017, the minimum wage in Mexico is 2,433MXN (128USD). As it can be noted, the amount a family
} 


\subsubsection{CCT Case Study 2: Bolsa Família in Brazil}

Brazil was the first country in Latin America to implement conditional cash transfer programmes. The Bolsa Escola, which later evolved to Bolsa Família, was the pioneer CCT in Latin America and served as the basis for most CCTs in the region, including the Oportunidades programme in Mexico. CCTs represented an important innovation in social policy as they attempt to alleviate poverty while giving incentives to improve human capital, shifting the focus from social assistance to social and human development.

Between the mid-1960s and late 1970s, Brazil experienced the combination of a dictatorial regime and an average annual GDP growth of $10 \%$; thus, anti-poverty policies were not a priority. However, the lesson from the 1980s was clear: the high economic growth of the 1970s did not promote a sustainable reduction in poverty, since the low economic growth of the 1980s pushed poverty back to levels of the mid-1970s. Thus, the widespread belief that economic growth alone would eradicate poverty was weakened, highlighting the need to design effective and more targeted anti-poverty policies (Pero and Szerman, 2005).

Under a variety of economic and institutional scenarios, economic and social inequality in Brazil has remained consistently high over the last thirty years. As a result, poverty levels have been higher than in other countries with similar development levels, despite the fact that public social spending has been proportionally higher than in other middle-income countries. Thus, the Brazilian social policy was soon perceived as historically inefficient and ineffective in attacking poverty. It was in this context that the idea of social safety nets appeared as a proposal for re-structuring the country's social assistance system. This restructuring consisted in changing the anti-poverty policies to consider Brazil's poverty profile to better target the most vulnerable sector of the population. In particular, the low level of human capital development was seen as a major cause of long-term poverty. To overcome this problem, proposals of CCTs were designed and put into practice starting in the mid-1990s (Pero and Szerman, 2005).

Brazil displays one of the lowest intergenerational education mobility in the world (WB, 2003) and faces a strong inverse relationship between education levels and poverty rates. There is a clear mechanism of intergenerational transmission of poverty that consists of a continuing vicious cycle of low schooling and poverty. Furthermore, poor children do not attend school since they must work to

with children in high school receives is 512MXN (27USD) more than the monthly minimum wage and thus an important contribution to the overall household income. For a full table of all transference values, please see Annex 4. 
contribute to their families' income. Poor families face high opportunity costs when sending their children to school. Based on this information, the CCTs started with two key premises. First, that in order to ensure their effectiveness and affordability, they should be targeted at poor families with school-age children. Second, that families should invest in the education of their offspring in order to break the vicious poverty cycle. Thus, in order to receive the transfers, beneficiaries must not only meet the eligibility criteria, but they should also enrol all their children in school, and assure a minimum school attendance. ${ }^{32}$ This is the concept of conditionality that was added to the programme's design, with the objective of guaranteeing investments in human capital, which would in turn promote a sustainable reduction of long-term poverty. In this way, the precursor of Bolsa Família, the Bolsa Escola Programme, was created in 1995 (Fiszbein et al., 2009). The central idea of Bolsa Escola, and later on, of Bolsa Família, was to alleviate current poverty and to tackle long-term poverty by giving money incentives to improve schooling. Its main objectives were: 1) to improve schooling levels of the beneficiaries; 2) to promote immediate poverty reduction; 3) to reduce the incidence of child labour; and 4) to create safety nets, minimising in this fashion the negative effects of both macro- and micro-economic shocks (Fiszbein et al., 2009).

Bolsa Família started in October 2003 with the fusion of four previously existing conditional and unconditional cash transfer programmes of the Brazilian federal government: Bolsa Escola, a minimum-income grant related to primary education; Fome Zero and Bolsa Alimentação, which were income grants related to food security, the former unconditional and the latter conditional on health check-ups and immunization updates; and Vale Gás, a subsidy to help poor households buy cooking gas (Veras Soares et al., 2010: 174).

Two key arguments supported the integration of these four programmes into Bolsa Família (Box 2.2). First, this integration would allow for a more comprehensive treatment of poverty, as the programme would be jointly an education, health and nutrition policy. Furthermore, a unified benefit with higher allowances could be offered instead of the fragmented allowances pre-reform. Thus the overall effectiveness could be enhanced both in terms of short-term poverty alleviation and long-term poverty reduction. Second, the integrated programme would be more efficient, since a single registry would be used to select the beneficiaries. The unification would mitigate the waste of resources and the duplication of functions.

\footnotetext{
${ }^{32}$ Children must attend at least $80 \%$ of the classes per month.
} 
Box 2.2 Federal CCTs in Brazil

\begin{tabular}{|c|c|c|c|c|}
\hline Programme & Bolsa Escola & $\begin{array}{l}\text { Bolsa } \\
\text { Alimentação }\end{array}$ & Fome Zero & Vale Gas \\
\hline Year & 2001 & 2001 & 2003 & 2001 \\
\hline Target & $\begin{array}{l}\text { Poor families (less } \\
\text { than } 90 \mathrm{R} \$ \text { per } \\
\text { capita) with } \\
\text { children between } \\
6 \text { - } 15 \text { years old }\end{array}$ & $\begin{array}{l}\text { Families with } \\
\text { pregnant/ } \\
\text { lactating women or } \\
\text { with children } \\
\text { between } 0 \text { - } 6 \text { years } \\
\text { old }\end{array}$ & $\begin{array}{l}\text { Poor families } \\
\text { (less than 90R\$ } \\
\text { per capita) with } \\
\text { children } \\
\text { between } 6 \text { - } 15 \\
\text { years old }\end{array}$ & $\begin{array}{l}\text { Poor families with } \\
\text { a per capita } \\
\text { income of less } \\
\text { than half a } \\
\text { minimum wage }\end{array}$ \\
\hline Objectives & $\begin{array}{l}\text { Eradicate child } \\
\text { labour, improve } \\
\text { school attendance }\end{array}$ & $\begin{array}{l}\text { Improve children's } \\
\text { nutritional status }\end{array}$ & $\begin{array}{l}\text { To improve } \\
\text { food } \\
\text { consumption } \\
\text { and nutrition }\end{array}$ & $\begin{array}{l}\text { To compensate } \\
\text { families for the } \\
\text { elimination of a } \\
\text { subsidy on } \\
\text { cooking gas }\end{array}$ \\
\hline Benefits & $\begin{array}{l}15 \mathrm{R} \$ / \\
\text { month per child, } \\
\text { up to } 3 \text { children } \\
\text { per family }\end{array}$ & $\begin{array}{l}15 \mathrm{R} \$ / \\
\text { month per } \\
\text { beneficiary, up to } 3 \\
\text { beneficiaries per } \\
\text { family }\end{array}$ & $\begin{array}{l}\text { 50R } \$ / \text { month per } \\
\text { family }\end{array}$ & $\begin{array}{l}\text { 15R } \$ \text { bimonthly } \\
\text { per family }\end{array}$ \\
\hline Conditionality & $\begin{array}{l}\text { Children must } \\
\text { have at least } 85 \% \\
\text { of school } \\
\text { attendance }\end{array}$ & $\begin{array}{l}\text { Women must attend } \\
\text { pre-natal care, } \\
\text { growth monitoring, } \\
\text { and vaccination } \\
\text { schedules; they } \\
\text { must send children } \\
\text { to day-care and pre- } \\
\text { school activities }\end{array}$ & & \\
\hline Coverage & $\begin{array}{l}\text { In 2001, } \\
5 \text { million } \\
\text { families }\end{array}$ & $\begin{array}{l}\text { In } 2003, \\
\text { nearly } 1.7 \\
\text { million } \\
\text { families }\end{array}$ & & $\begin{array}{l}9.7 \text { million } \\
\text { Families } \\
\text { in } 2003\end{array}$ \\
\hline
\end{tabular}

Source: Author's creation

The main objectives of Bolsa Família are: a) to reduce current poverty and inequality, by providing a minimum level of income for extremely poor families; $b$ ) to break the inter-generational transmission of poverty by conditioning these transfers on beneficiary compliance with human capital requirements (school attendance, vaccines, pre-natal visits); and c) to empower beneficiaries by linking them to complementary services (Lindert et al., 2007). The programme targets extremely poor and poor families at the national level through a combination of methods based on geographic and income per capita-household assessments. Geographic targeting is applied at the federal and municipal levels. Family eligibility is determined centrally based on household registry data collected locally and transmitted by the municipality into a central database known as Cadastro Único. Box 2.3 provides an overview of Bolsa Família's eligibility criteria, beneficiary identification, benefits, conditionalities, institutional arrangements, and monitoring and evaluation. 
Box 2.3 The Bolsa Família Programme

\begin{tabular}{|c|c|}
\hline Eligibility criteria & $\begin{array}{l}\text { Extremely poor families with less than } \mathrm{R} \$ 50 \text { of family income } \\
\text { per capita and poor families (less than } \mathrm{R} \$ 100 \text { ) with pregnant, } \\
\text { lactating women, and/or children from } 0 \text { to } 12 \text { years old and } \\
\text { teenagers up to } 15 \text { years old. }\end{array}$ \\
\hline $\begin{array}{l}\text { Beneficiary } \\
\text { identification } \\
\text { and selection }\end{array}$ & $\begin{array}{l}\text { Bolsa Família uses the Cadastro Único-a national registry of } \\
\text { poor households- for beneficiary selection. Data collection and } \\
\text { beneficiary registry are responsibility of the municipalities, but } \\
\text { operation and maintenance of the database are centralized at the } \\
\text { federal level by the Ministry of Social Development. The Caixa } \\
\text { Econômica Federal (CEF) is responsible for the system's } \\
\text { management and operation. }\end{array}$ \\
\hline Benefits & $\begin{array}{l}\text { The extremely poor families receive a fixed amount }(\mathrm{R} \$ 50) \text { plus } \\
\text { variable cash transfers depending on family composition. These } \\
\text { families receive } \mathrm{R} \$ 15 \text { per child from } 0 \text { to six years of age and } \\
\text { teenagers until } 15 \text { years old, up to three children per family. The } \\
\text { total transfer for the extremely poor families ranges from } \mathrm{R} \$ 65 \text { to } \\
\mathrm{R} \$ 95 \text { (USD22-33). For poor families the total transfer ranges from } \\
\mathrm{R} \$ 15 \text { to } \mathrm{R} \$ 45 \text { (USD5-15). }\end{array}$ \\
\hline Conditionalities & $\begin{array}{l}\text { Enrolment and regular school attendance of children ages } 6-15 \\
\text { years } \\
\text { Vaccines up to date for children ages 0-6 years } \\
\text { Pre-natal visits for pregnant women }\end{array}$ \\
\hline $\begin{array}{l}\text { Institutional } \\
\text { arrangements }\end{array}$ & $\begin{array}{l}\text { Bolsa Família is administrated by Secretaria Nacional de Renda } \\
\text { de Cidadania (SENARC) in the Ministry of Social Development } \\
\text { (MDS), which is responsible for the supervision of the } \\
\text { programme's operation and benefit payments. It is guided by } \\
\text { the decisions of the President, supported by the } \\
\text { recommendations of management board (the Comitê Gestor do } \\
\text { Programa Bolsa Família), which is responsible for policy } \\
\text { articulation, promoting partnerships between levels and sectors } \\
\text { of government and with civil society, overseeing formal audits } \\
\text { andsocial controls. (World Bank, 2003). }\end{array}$ \\
\hline $\begin{array}{l}\text { Monitoring and } \\
\text { Evaluation }\end{array}$ & $\begin{array}{l}\text { Local agents from municipalities check conditionalities, but the } \\
\text { quality control of the processes, the compliance with } \\
\text { conditionalities, payments, and the Cadastro Único information } \\
\text { is responsibility of the SENARC/MDS. Besides, it also conducts } \\
\text { the impact evaluation of the programme. }\end{array}$ \\
\hline
\end{tabular}

Source: Author's creation based on Lindert et al. (2007) 


\subsection{Previous Findings About the Impact of CCTs on the Empowerment of Women in Latin America}

In practice, most CCTs focus on mothers as the key to securing improvements in the life chances of their children (Molyneux, 2010). By disbursing grants to women, CCTs also aim to promote gender equality (Maldonado et al., 2006; Son, 2008). Targeting the cash transfer is the most explicit gender-sensitive design feature of most CCTs (Holmes et al., 2010). In 17 out of the 23 CCTs in Latin America (World Bank, 2009), the stipend is paid directly to the mother. The rationale behind this is twofold: firstly, research into intra-household resource allocations has shown that they are often biased against girls and women (see for example Devereux, 1999). The policy of giving transfers directly to female caregivers can therefore be seen as an attempt to tackle gender-biases in intra-household resource allocation and to create more equality (Devereux, 1999; Samson et al., 2006). Secondly, policy makers hypothesize that ear-marking the transfers for investment in children "could strengthen the mother's bargaining position and reinforce her ability to shift household spending and time allocation decisions" (World Bank, 2009: 59). This holds the potential to transform gender relations and is thus closely aligned with rights-based ideals and a more comprehensive concept of poverty alleviation.

Moreover, empirical research has demonstrated that women invest more resources in nutrition and in their children's education and health than men do (Barrientos and De Jong, 2004 and 2006; Schady and Rosero, 2008). Thus, disbursing cash transfers to women increases the likelihood of the programme's success, which is explicitly named as one of the reasons for this mode of delivery. According to the WB and national governments, when women receive cash transfers, they also become co-responsible for fulfilling the conditions and thus for the programme's success. Co-responsibility is one of the guiding principles of CCTs, as beneficiary families are expected to take an "active part" in the achievement of their own development (Sedesol, 2003). However, by allocating the transfers to women, the programmes effectively delegate this responsibility to women alone (Molyneux, 2007b). As co-responsibility often entails participating in health and nutrition lectures, taking children to health check-ups and ensuring school enrolment, it works best in nuclear families with a traditional division of labour (Molyneux, 2006). Therefore, this design feature, while having the potential to increase women's bargaining power, also points to an instrumental use of women's traditional gender roles.

School enrolment is the main requirement in virtually all CCTs that have at their core the improvement of children's human capital. Two out of 23 CCTs in Latin America differentiate the benefit structure according to the sex of the children, but only Oportunidades in Mexico pays higher stipends for girls. This is meant both as 
an incentive for parents to send girls to school and as a message that girls are worth investing in (Molyneux, 2007b). It also signifies an effort to increase gender equality in the next generation in its own right, as it enhances girls' capabilities beyond the narrow focus on traditionally female occupations and tasks. ${ }^{33}$

In Latin America, seven out of 23 CCTs listed in the WB 2009 overview also require women to participate in health and nutrition lectures. Some critics (see, for example, Bradshaw, 2008) state that although the enhancement of women's skills is positive, providing training in health and nutrition is also instrumental to the programme's success and thus does little to build women's capacity per se. Other CCTs in LAC offer literacy courses (Bolsa Família, Brazil), psychological assistance (Chile Solidario, Chile), capacity-building (Solidaridad, Dominican Republic), complementary social services (Juntos, Peru), and vocational training for women (Atención a Crisis, Nicaragua) (Holmes et al., 2010). Although they also contribute to material poverty reduction, these measures are designed to expand women's opportunities to take up work and provide for themselves during and after their children's education. They also form "a stronger fall-back position in case of abandonment, separation, or divorce" (Razavi, 2009: 24). In this way, they have greater potential for transforming gender relations.

One of the defining elements of the multidimensional concept of poverty is that it combines consumption-based poverty measures with human development indicators and rights. Quantitative analyses of the impact of six CCTs on shortterm consumption or income in Latin America show that the transfers increased average consumption levels for beneficiary households by $7 \%$ (Brazil) and $29.3 \%$ (Nicaragua) on average (World Bank, 2009). This is a very positive impact on the material poverty of women and their households. As previously stated, policy makers hypothesise that disbursing the transfers directly to women strengthens their position in the household. Indeed there is some evidence from Mexico (Adato et al., 2000; Espinosa, 2006) and Brazil (Holmes et al., 2010) that women's bargaining power with regard to how the transfers are spent increases compared to that of women who are not enrolled in the programme. However, an in-depth analysis of Oportunidades by Adato et al. (2000) showed that women's past work experience is the most important determinant of how much decision-making power women in the programme have, while enrolment itself has little effect. This calls into question whether the positive impact on women's bargaining power can be attributed solely to the programme.

Other evaluations show that the transfers increase women's self-esteem because they do not have to ask their husbands for money every time they need to make

\footnotetext{
${ }^{33}$ Such as child-bearing, cooking, cleaning, and taking care of the household in general.
} 
purchases. In this way, women also gain more confidence in their ability to judge independently what the household needs (Adato et al., 2000; Espinosa, 2006). This finding is relevant since the 1990 Human Development Report explicitly names "personal self-respect" (UNDP, 1990: 1) as an integral aspect of the human development process. In addition, the health and nutrition lectures provide women with an opportunity to leave the house and bond with other women. In some communities, women use these meetings to "share problems and solutions, and realise their common experiences" (Adato et al., 2000: 69). Women beneficiaries describe this as an empowering experience. Oportunidades has also decreased levels of domestic violence. Women who participate in the programme are victims of domestic violence less often (34.5\%) than women who were not enrolled in the programme (40.4\%) (Rivera, Hernández, and Castro, 2005).

On the negative side of the ledger, several evaluations find that CCTs increase women's time burden because the additional co-responsibility tasks are added to women's regular reproductive activities (Parker and Skoufias, 2000; Rubio, 2002). Qualitative research on Oportunidades shows that before they leave for their meetings, women make great efforts to ensure that their husbands get their meals. The authors believed that this is "clearly the price they are willing to pay for domestic harmony" (Adato et al., 2000: 53); reports of self-exclusion due to an overwhelming workload seem to be the exception (Escobar Latapí and González de la Rocha, 2009). Other studies, in contrast, find that women felt '“discriminated against" by programme demands on their time' (Molyneux, 2007b: 27). Qualitative research from Nicaragua indicates that this additional time burden is especially hard on families with female breadwinners, who often drop out of the programme or do not enrol in the first place. Increased time burdens show that some of the costs of the programme are imposed on women by putting them in a position where they increase their own (time) poverty for the welfare of others and, by extension, the programme's efficiency.

Enhanced self-esteem, increased bargaining power, and reduced domestic violence are clearly positive impacts on the situation of women that go beyond material reduction of their poverty and point towards an increase on women's empowerment. However, attention must be paid to the programme impacts for a number of reasons: firstly, the negative impact on women's time poverty is often ignored in impact evaluations but represents an important (gendered) impact when looking at comprehensive poverty reduction. Secondly, the empowering feeling of solidarity among women and their increased self-esteem seem to be indirect effects of the programme design rather than planned-for outcomes. Thirdly, the positive impact on women's bargaining power, while stated as an explicit goal of the disbursement to women, is not directly attributable to the 
programme's design, as past work experience is more significant in explaining women's decision-making power (Adato et al., 2000; Herzog, 2011).

This latter finding is important both from a conceptual and a policy point of view. It shows that a feeling of empowerment stems from an enhancement of women's capabilities in the sense of a comprehensive poverty reduction approach rather than from monetary inputs in a more narrow sense. Moreover, it implies that some CCTs could have a larger impact on women's decision-making power and empowerment if they offered vocational training or other means to increase women's capabilities to engage in income-producing activities. This is important since, although women value Oportunidades and Bolsa Família and their benefits, what they want most is education that allows them to engage in productive activities (Adato et al., 2000: 82).

Besides increasing the programme's efficiency, making women co-responsible for the targets of CCTs also reinforces traditional gender roles and thereby restricts the potential for transformation of gender relations. As already mentioned, the standard CCTs work best in nuclear families with a traditional division of labour (Molyneux, 2006). By devolving the responsibility for investment in children's human development to women, CCTs often reinforce women's roles as mothers and caregivers. Moreover, the decision to channel resources through women makes deliberate use of the inequality of men's and women's inputs into their children's development (Chant, 2008). As Bradshaw argues, "men's behaviour is implicitly recognized as problematic but is not addressed, while the personal deprivation suffered by women through their altruism is not problematised but explicitly reinforced as the social norm" (2008: 195).

Some critics of the CCTs state that the naturalisation of women as mothers and caregivers is intensified when there is a lack of holistic investments to alleviate their poverty. CCTs put significant time burdens on women, but only few offer capacity-building that would enable them to graduate out of the programme by their own means. The critics state that, in fact, the increased time burden alone makes engagement in additional income-generating activities less likely and therefore indirectly increases women's dependence on others to provide for them (see for example, Molyneux, 2007a; Bradshaw, 2008; Chant, 2008). From a material point of view, this still leaves them better off for the duration of the programme; however, from a more comprehensive view of poverty, this leaves little space for the transformation of gender relations or the increase of women's choices for themselves. Bradshaw concludes that "any change that may come out for women will be within these gendered norms of behaviour" (2008: 199). Examples of such a change are the lectures that open up spaces for women to discuss their experiences and connect with other women. This is an unintended but positive outcome of the 
CCTs. However, its potential for transforming gender relations is at best indirect, as men are missing from the programme design. And women beneficiaries point out, as it will be seen in the empirical chapters, that men should also be included in the guidelines of the CCTs.

\subsection{Conclusion}

In this chapter, the concepts of feminisation of poverty, social protection and gender, and conditional cash transfers were discussed. Also, the main characteristics and objectives of Oportunidades in Mexico and Bolsa Família in Brazil were described. Finally, some results that have been observed by other researchers were offered.

The term "feminisation of poverty" was coined in the 1970s but became an emblem in the international development discourse in the mid-1990s, at the same time that the universal provision of social protection changed towards a targeted approach. Conditional cash transfers started in Latin America in the mid-1990s following the need for more efficient and focalised social protection. CCTs have at their core the two-fold objective of alleviating short-term poverty by providing transfers, and of enhancing human capital in the long-term by providing access to education, nutrition and health. In this manner they aim at breaking the vicious cycle of poverty traps.

In Mexico, Oportunidades started in 2002, following the Progresa programme. Its main objectives are to increase the basic capabilities of families living in extreme poverty, through the promotion of the education, health and nutrition, and to support their access to goods and services that could help them develop skills and break the intergenerational poverty cycle. The transfers are given to the female head of the households and support rural, semi-urban, and urban populations. Currently, Oportunidades provides transfers to 6.1 million families (circa 30 million people). In Brazil, Bolsa Família started in 2003 following the fusion of four previously existing cash transfer programmes (Bolsa Escola, Fome Zero, Bolsa Alimentação, and Vale Gás). Its main objectives are: 1) to improve schooling levels of the beneficiaries; 2) to promote immediate poverty reduction; 3) to reduce the incidence of child labour; and 4) to create safety nets, minimising in this fashion the negative effects of both macro- and micro-economic shocks. The transfers are given mostly to the mothers of the households. The programme supports rural, semiurban, and urban populations. Currently, Bolsa Família provides transfers to 14 million families (circa 50 million people) and it is the largest CCT in the world.

Previous results show mixed evidence regarding the effect of CCTs in Latin America. While some researchers show positive results regarding women's 
empowerment (Parker and Skoufias, 2000; Escobar Latapí and González de la Rocha, 2009), other critics (Adato et al., 2000; Bradshaw, 2008; Chant, 2008) state that CCTs reinforce traditional gender roles that continue to be detrimental to women. The mixed evidence shown in previous studies inspired this research and the carrying-out of this study. The next chapter will explain the theoretical framework and the research methods used. 


\section{Chapter 3. Theoretical Framework of Empowerment and Research Methods}

\subsection{Introduction}

The concept of women's empowerment derives from the fact that power relations are embedded in relationships between men and women, in other social relationships in which women are involved, and within institutions that affect women's lives -including households, the state, the market, and other domains of civil society. Women's empowerment thus implies a shift in these power relations in favour of women (Adato and Roopnaraine, 2010).

One definition of women's empowerment is "an expansion in the range of potential choices available to women so that actual outcomes reflect the particular set of choices which the women value" (Kabeer, 2003: 81). Empowerment is also seen as "the process by which the powerless gain greater control over their lives, gaining power to achieve goals and ends" (Kishor and Gupta, 2004: 694). Thus, exercising choice is seen as gaining power. While the process of empowerment is applicable to both sexes, it is more relevant for women since women's disempowerment is more pervasive as it cuts across class and other social distinctions. Further, it is made more complex by the fact that household and intrafamilial relationships are a major source of women's powerlessness (Malhotra et al., 2002). Drawing upon the above insights, and bearing the complexities in mind, empowerment broadly means having increased life options and choices, gaining greater control over one's life, and generally attaining the capability to live the life one wishes to live. These definitions imply that empowerment is a dynamic process of change whereby "those who have been denied the ability to make choices acquire such an ability" (Kabeer, 1999: 437). It is also a process that is more relevant for those who are "powerless," since it entails going from a "disempowered" state to a more "empowered" one.

This chapter is structured in the following way: the second section defines the concept of empowerment, and explains its different dimensions and challenges in its measurement. The third section states the research methods of this dissertation, explaining the data collection, sample description and data analysis. Finally, the last section provides the limitations of the methods. 


\subsection{The Concept of Empowerment}

\subsubsection{Empowerment in the International Arena}

During the 1980s and 1990s the process of globalisation of the world economy led to the feminisation of labour and poverty, whereby women expanded their unpaid labour to compensate for the increase in poverty and loss of local resources, resulting in an exacerbated sexual division of labour (see, for example, Pearce, 1978). Due to these developments, empowerment became a key concept in international development. Empowerment is central to the work of enhancing well-being and improving human lives (see Sen, 1999; Zimmerman, 2000; Malhotra et al., 2002). Across disciplines, it is widely agreed upon that empowerment processes encompass material resources and inequities in the environment, strengths of the individual and a sense of personal control, and the enhancement of well-being (Kabeer, 2003).

In recent decades, the international development field has begun a concerted effort to broadly address women's empowerment with organisations ranging from the World Bank to grassroots, and from non-governmental organisations to the United Nations, all advocating for women's human rights and empowerment in an effort to address UN Millennium Development Goal 3: to promote gender equality and empower women. In addition, the gender perspective is incorporated in several of the SDGs, especially in the SDG 1 (End poverty in all its forms everywhere), SDG5 (Achieve gender equality and empower all women and girls), and SDG 10 (Reduced inequalities within and among countries).

However, despite this growing awareness it still remains unclear what is meant by women's empowerment. When policymakers and interventionists include empowerment as a development goal, what are they trying to accomplish and how do they determine whether it has been achieved (Malhotra et al., 2002)? The gap in empirical support for empowerment processes in this context may stem from the fact that research in this area does not have a recognised niche in any one academic field. Several reviews have demonstrated that most investigations surrounding women's empowerment have emerged from economics, demography, sociology and public health. Thus, despite the proliferation of empowerment rhetoric in the championing of global social interventions, the explicit connections between empowerment research and programme development are in many cases tenuous (see Perkins and Zimmerman, 1995). A transdisciplinary analysis with an integration of perspectives and methods drawn from diverse disciplines would be necessary to close this gap. 
In the 1970s women's empowerment was first invoked to facilitate a struggle for social justice and women's equality through a transformation of political structures. However, by the 1990s many development agencies began using the term empowerment in association with a wide variety of strategies in isolation from women-centred agendas and applied it, instead, to the context of broad-based neo-liberal economic development strategies (Perkins and Zimmerman, 1995). Within psychology, empowerment has been defined as a sense of personal control and freedom, whereby individuals gain agency and mastery over issues of concern to them and are supported by access to and control over resources (see Rappaport, 1987; Zimmerman, 2000). Empowerment theory also links subjective well-being with larger social and political contexts and integrates a critical understanding of the socio-political environment. In the international development literature, empowerment has largely come to refer to the expansion of freedom of choice and action to shape one's life, yet it is recognised that for many marginalised groups such freedom is severely curtailed by lack of opportunity determined by structural inequities (Narayan, 2005).

Structural power, whereby dominant individuals and groups have more control over resources than subordinates, is one of the major contributors to social inequalities (Weber, 1968). A growing body of evidence suggests that institutionalised inequalities in the distribution of resources contribute to power imbalances and gender-based norms that create an environment that legitimises and perpetuates women's subordinate status. Because the economic policies of the 1980s and 1990s introduced or exacerbated several structural factors that have contributed to rising levels of gender inequality, rapidly changing conditions in the restructuring of resources in developing countries provide a perfect context for an analysis of social structures that reflect dominance and power (Grabe, 2012). Women's organisations and social movements where women can collectively address injustices have an important role to play in creating the conditions for change (Kabeer, 1999). As Freire (1970) suggested, collective organising and raising awareness of one's own social reality is a vital means to initiating action and creating social changes.

\subsubsection{Definition of Empowerment}

Naila Kabeer understands empowerment as "a process of change during which those who have been denied the ability to make strategic life choices acquire such an ability" (Kabeer 1999: 437). According to Kabeer, three interrelated components -resources, agency, and achievements- are critical to understanding the concept and process of empowerment. Resources may be construed as material or social, and are considered the means through which agency, or the ability to exercise choice, is carried out. Achievements refer to the outcomes of agency. This approach 
is set apart from a singular focus on agency and highlights the profound importance of social context in empowerment processes.

Empowerment occurs at a number of different levels, covers a range of different dimensions and materialises through a variety of different processes. Intertwined with the idea of empowerment is the concept of power. Such a concept is central for clarifying the concept of empowerment that is used in this dissertation. One way of thinking about power is in terms of the ability to make choices (Kabeer, 1999). Empowerment entails a process of change from not being able to make strategic life choices to acquiring such ability. Linked to the analysis of power, the ability to make choices means that choice necessarily implies alternatives, the ability to have chosen otherwise. There is an association between poverty and disempowerment because an insufficiency of a person's material means for meeting their basic needs may impose painful trade-offs between important dimensions of choice.

Poor people may feel powerless and voiceless. They behave in certain ways and sometimes do not even try to change the status quo because they do not even conceive the fact that they can choose otherwise. For empowerment to take place, poor people, in this case, poor women, need to feel the ability to make strategic life choices (choice of livelihood, where to live, whom to marry, whether to marry, whether to have children, who has rights over the children, freedom of movement and choice of friends) that are critical for them to live the lives they want (Kabeer, 1999).

For the purposes of this study, the ability to exercise strategic life choices will be understood as consisting of three dimensions, based on Kabeer's empowerment framework.

\section{Figure 3.1 Empowerment framework}

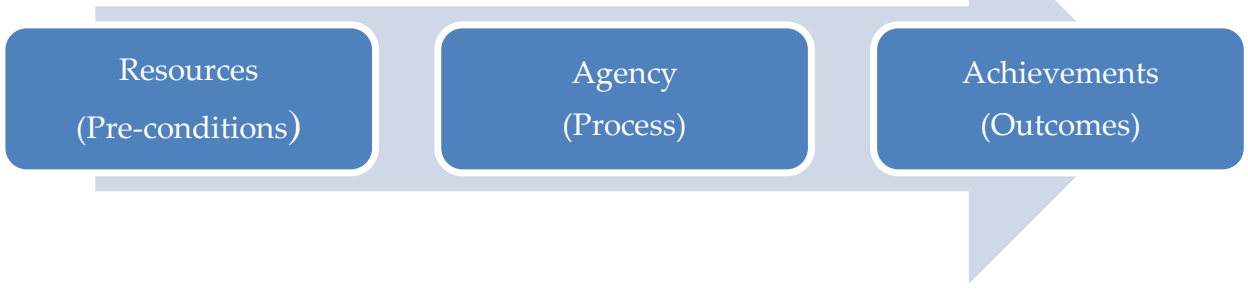

Source: N. Kabeer (1999)

The first dimension of empowerment relates to resources. People's access to resources (material, human and social) reflects rules and norms that give certain 
actors authority over others in determining the principles of distribution and exchange in different institutional arenas (household, market, community) (Kabeer, 1999). Resources encompass material, human and social resources that enhance the ability to exercise choice. Resources in this broader sense are acquired through a variety of social relationships conducted in the various institutional domains that make up a society, including the domains of family, market, state and community.

Although resources may provide the material conditions through which gender inequalities are produced, cultural ideology, i.e. social rules, norms and values that govern gender roles, plays a critical role in how they are sustained (Glick and Fiske, 1999). Because of cultural ideologies surrounding gender, women's lack of access to institutional resources is a central locus of disempowerment in a way that is not true for other disadvantaged groups (Malhotra et al., 2002). Thus, considering women as a group involves questions about what women have in common that warrants the interest in women's empowerment, in particular.

According to Social Dominance Theory, ideologies are functional and serve to promote or maintain group inequality (Pratto, 1996). Hence, women's empowerment is likely to involve an awareness of the socio-political environment that can lead to an emergence of new beliefs about the right to exercise capabilities and take advantage of opportunities in one's community. In this chapter, I analysed how conditional cash transfers can provide such an awareness to the beneficiaries and how they impact women's empowerment in the areas of personal and psychological empowerment. Nonetheless, while external conditions are necessary for empowerment, material resources alone do not inevitably lead to empowering processes if people do not have internal feelings of competence (Diener and Biswas-Diener, 2005).

The second dimension of the empowerment process relates to agency, which is the ability to define one's goals and act to try to achieve them. Agency entails more than just observable action. It also encompasses the meaning, motivation and purpose that individuals bring to their activity - their own sense of agency, or what feminists call the "power within." Agency can be manifested as decisionmaking, bargaining, negotiation, deception, manipulation, subversion and resistance, as well as cognitive processes of reflection and analysis. The third dimension of empowerment relates to achievements. Achievements are outcomes, represented in studies of empowerment as indicators (Kabeer, 1999).

Resources and agency together constitute what Sen (1999) refers to as capabilities, the potential that people have for living the lives they want, of achieving valued ways of being and doing. Sen uses the idea of "functionings" to refer to all the 
possible ways of being and doing that are valued by people in a given context, and of "functioning achievements" to refer to the particular ways of being and doing that are realised by different individuals (see Sen, 1985; Kabeer, 1999). When the failure to achieve one's goals reflects some deep-seated constraint on the ability to choose, it can be taken as a manifestation of disempowerment.

Furthermore, it must be mentioned that there are a number of measurement issues to consider when measuring empowerment. First, the empowerment process is not directly observable: it can only be approximated using proxies or indicators. For example, the initial resources that women can draw upon and are considered the prerequisites to exercise choice are generally indicated by paid employment, education, and media exposure, but there is no guarantee that these will necessarily translate into agency. Similarly, the ability to exercise choice can only be observed up to a point, since the motivations and purposes behind that choice are not evident. Indicators that have been commonly identified to measure agency have included observable actions like participation in decision-making, financial independence, and freedom of movement. However, as Kabeer (1999) points out, agency can also take forms that incorporate motivations and intentions that are less amenable to measure, like bargaining and negotiation, cognitive processes of reflection and analysis, and attitudes to or rejection of gender-based subordination of women (Kishor and Gupta, 2004).

Second, empowerment is a multi-dimensional process. Gender inequality exists across different dimensions (social, economic, political, and psychological) and in various domains of women's lives. The causal pathways through which resources are translated into agency can also be varied: material, perceptual, relational, and cognitive (Chen and Mahmud, 1995). If the hypothesis is that increased agency enhances women's well-being by reducing gender inequality in health status, educational status, personal security, and so on, then the causal pathways of influence from agency to favorable outcomes also need to be identified. Indicators need to be specified and measured across various dimensions and along different pathways. There may be independence in the experience of empowerment across various domains. For example, women may gain greater agency and control within the family sphere without complementary changes in the community or public spheres. On the other hand, empowerment in one dimension can lead to empowerment in another. For example, women's agency in terms of gaining control over material resources can lead to greater participation in household decision-making (Mahmud et al., 2012).

Third, context is crucial. The particular pathways of change vary from context to context, and even within the same context all women may not experience empowerment within the same dimensions. This is particularly evident in the 
different ways household wealth and age can shape the empowerment process. Indicators can also be either context specific or universal. An indicator of freedom of mobility, for example, is much more relevant in a patriarchal context, where women are traditionally confined to the home, than in a western context.

\subsubsection{Challenges in the Measurement of Empowerment}

Most of the current definitions of empowerment in the development literature draw upon Amartya Sen's (1999) articulation of "Development as Freedom," where development is understood as expanding people's choices. For example, Bennett (2002) defines empowerment as the enhancement of assets and capabilities of diverse individuals and groups to engage, influence and hold accountable the institutions which affect them. Sen (1990) defines empowerment as altering relations of power [...] which constrain women's options and autonomy and adversely affect health and well-being. For Batliwala (1994) empowerment is how much influence people have over external actions that matter to their welfare. Kabeer (2003) defines it as the expansion in people's ability to make strategic life choices in a context where this ability was previously denied to them.

Hence, control over resources -physical, human, intellectual, financial- is one of the most important dimensions of the concept of empowerment (Kabeer, 1999). The second dimension shared by most definitions is women's agency. Agency means that women themselves have the right to make choices and should be involved in determining which choices make the most sense for them and their families (Kabeer, 1999). Third, since empowerment implies a movement from being without power to having power, most definitions also imply that it is a process that involves change over time. Finally, empowerment is also understood as an outcome, such as an improvement in education, health, and economic and political participation. Very often, however, women's empowerment and gender equality are used interchangeably. While they are related, they are not the same. Gender equality is about women's status relative to men while women's empowerment is about women's ability to exercise control, power, and choice over practical and strategic decisions (Grown, 2006). There is consensus on defining empowerment; however, most measures have only quantified the dimensions of control over resources and outcomes. Women's agency and process remain difficult to measure. The most common indicators measure capabilities -education and health in particular- and control over economic and political resources and decision-making.

Malhotra et al. (2002) suggest expanding empowerment to include six dimensions: economic, socio-cultural, family/interpersonal, legal, political, and psychological. Each of these dimensions is complex with various sub-dimensions. For example, 
the economic dimension would include labour force participation, wage differential, and sex segregation among others. They also identify three levels for measuring empowerment: household, community and broader areas. Charmes and Wieringa (2003) have defined a Women's Empowerment Matrix (WEM) that consists of six dimensions (physical, socio-cultural, religious, economic, political, and legal) and six levels (individual, household, community, state, region, and global). Grown (2006) defines three domains of empowerment (adopted by the Millennium Project Task Force on Education and Gender Equality). The first one is the capabilities domain, which evaluates knowledge and health factors through indicators of education, health, and nutrition. The second one is the access to resources and opportunities domain, which primarily refers to access to political decision making and economic assets. And the last one is the security domain, which considers violence and conflict matters.

There are several challenges to measuring the dimensions and levels identified above. First, there is a lack of gender disaggregated data for most dimensions and levels. While gathering statistics and building national capacity for data collection have been reiterated in most UN agencies' reports, much remains to be done. Hence, most measures are able to identify only aggregate or household level empowerment. Community, state and regional data exist for very few countries. Second, analysts agree that empowerment is context-specific. While the international declarations and conventions represent a universal framework for equality, empowerment varies within and across countries. Reconciling context specific indicators with a universal measure remains an issue. Some empirical studies have successfully addressed this. For example, Mason and Smith (2000) and Jejeebhoy and Sathar (2001) used similar indicators with slight modifications in wording in five countries in Asia, across fifty nine communities, but this is harder to do on a global level.

Third, measuring process is elusive. Most quantitative measures are unable to capture this except as changes over time of proxy variables such as education or employment. The best measure would capture decision making control in various dimensions over time. As Malhotra et al. (2002) note, process is also difficult to measure as behaviours change over time and what was once rare becomes normative. For example, the use of birth control by women in rural Bangladesh in the 1990s was considered empowering but now that more than half of all married women do so, it is normative. Moser (1998) indicates another issue with the measuring process. The measurement cannot be just linear, as change happens over a long time and in unexpected ways.

Fourth, similarly, agency is difficult to measure. It has been measured at the household level in terms of women's ability to make economic and social 
decisions. But since agency implies that the woman's own consciousness has been transformed, it would have to be measured based on women's own interpretation of what is important to them and what they perceive has changed about their own knowledge and perspective. This can mainly be achieved through ethnographic studies or surveys at local levels. Alternatively, Malhotra et al. (2002) suggest that at an individual level, it could be measured in terms of difference between individual behaviour and community norm.

\subsection{Rationale for Choice of Research Methods, Cases and Research Sites}

A case study approach (Yin, 2014) was chosen for this research because it allows to gain an in-depth understanding of the women's perceptions, experiences and circumstances in two country contexts with similar CCT programmes (Brazil and Mexico). This study is context specific research - the case study objective was to analyse the perceptions and experiences of women beneficiaries regarding the CCT receipt and the cultural, social and policy conditions that facilitate the empowerment of women living in extreme poverty within the researched communities.

Yin defines a case study as "an empirical enquiry that investigates a contemporary phenomenon in depth and within its real life context, especially when the boundaries between the phenomenon and context are not clearly evident" (2014: 18). A case study is the study of the unique and unusual, and its main purpose is to explore that particularity and uniqueness (Simons, 2009: 3). This method was utilised since it can be used to generate an in-depth understanding of a specific topic, programme, policy, organisation, institution or system (Simons, 2009: 21). The approach is explanatory and seeks to explain the causal links in human phenomena that are too complex for experiments and surveys (Yin, 2014: 19). Like experiments, case studies can be used to develop theoretical propositions. This is why case study research was found to be the most appropriate approach for this study. The propositions developed based on this study are stated in chapter 6 .

Sociological qualitative research brings more nuance to the existing knowledge in the area of study-in this case the effects that CCTs can have on women's empowerment. Quantitative methods can provide numeric knowledge about the impact of a programme; however, this research is qualitative in nature, and it shows how women beneficiaries perceive the receipt of the CCTs and how CCTreceipt is related to the decisions they make and what it means for them, particularly in the areas of labour market participation, intra-household decisionmaking, and feelings of self-worth. 
Measuring the effects of Oportunidades/Prospera and Bolsa Família on women's status, intra-household decision-making power and empowerment, and the process through which these effects occur, is challenging. Women's status is difficult to quantify with large household surveys (like ENCASEH ${ }^{34}$ and ENCELs ${ }^{35}$ in Mexico, and PNAD ${ }^{36}$ in Brazil). ENCASEH, ENCELs and PNAD contain several questions which attempt to explore various aspects of women's status and bargaining power, such as attitudes towards women's roles, questions on who within the household takes more responsibility for certain household decisions, questions on the disposition of women's income, and questions on women's mobility and freedom of movement. Nonetheless, these household surveys are not particularly useful instruments to analyse intra-household dynamics since the context of such dynamics is often unstated; and without adequate understanding of the socio-cultural context, survey results can be easily misinterpreted. Therefore, to avoid the danger of having results which do not reflect the conditions of women's empowerment processes within its socio-cultural context, a qualitative case study approach was used.

In terms of choice of CCTs, the contexts of Mexico and Brazil are the most interesting in Latin America for this area of study. Both Oportunidades/Prospera and Bolsa Família have nationwide coverage in the most populous countries of Latin America, making them the largest conditional cash transfer programmes in the world in terms of number of beneficiaries. In addition, both Mexico and Brazil have prioritised women's empowerment, making it one of the primary goals of both Oportunidades and Bolsa Família. As such, Oportunidades and Bolsa Família provide an interesting opportunity to study the perception and experiences of women beneficiaries regarding CCT-receipt, in specific contexts (rural, semi-urban and urban areas).

The Oportunidades/Prospera programme in Mexico and the Bolsa Família programme in Brazil were selected as case studies based on the fact that both programmes are the largest CCTs in the world and that they share similar characteristics, such as: duration of implementation, population covered, monitoring and evaluation systems in place, human capital approach, and focus on gender. These programmes are also the leading CCTs in Latin America and the analysis of their effects is relevant in order to extract policy lessons and recommendations for other countries in the region, and the world, that would like to promote gender equality and poverty reduction.

\footnotetext{
34 Encuesta de Características Socioeconómicas de los Hogares, Survey of Socio-Economic Household Characteristics.

${ }^{35}$ Encuesta de Evaluación de los Hogares, Survey of Household Evaluation.

${ }^{36}$ Pesquisa Nacional por Amostra de Domicílios, National Survey by Household Sampling.
} 
First, a desk poverty mapping of the poorest areas in Mexico and Brazil was carried out, using demographic data of the Mexican (ENCASEH and ENCELs) and Brazilian governments (PNAD). Once the poorer states in both countries were found, Campeche and Ceará were chosen due to their similar characteristics (e.g. they both are among the poorer states in Mexico and Brazil, they both receive a high percentage of the national budget for CCTs, and a high percentage of their population receive CCTs). Once on the field, we visited the Ministries for Social Development in Campeche City and in Fortaleza to find out which were the poorest neighborhoods with the highest numbers of beneficiaries. Beneficiaries and non-beneficiaries of the Oportunidades and Bolsa Família programmes in Campeche, Hecelchakán, and Tenabo in Mexico, and in Fortaleza, Quixadá, and Mangue Seco in Brazil were interviewed.

Since Mexico and Brazil are rather large countries, the research focused on the Campeche state in Southeast Mexico and the Ceará state in Northeast Brazil (see Figure 3.2 and Figure 3.3). These states were selected because they both are among the poorest in their countries, and they receive a higher share of the national budget allocated to CCTs (Progresa, 2000b; Lindert et al., 2007). Furthermore, the number of beneficiaries in these states is higher than in other states of these countries. They share similar poverty, development and inequality levels, and they both need more in-depth research on the effect of CCTs, especially in the gender area, as there is a lack of research (Villatoro, 2005; Skoufias, 2006; Valencia, 2008).

Once the states were selected, an urban, semi-rural and rural community in each country were selected in order to obtain territorial diversity in terms of geographical location and size of city/community, and its level of development. Following this reasoning, the capital city of Campeche, Campeche City, was chosen as the urban case in Mexico, Hecelchakán as the semi-rural, and Tenabo as the rural case. In Brazil, the capital city of Ceará, Fortaleza, was chosen as the urban case, Quixadá as the semi-rural case, and Mangue Seco as the rural case.

In order to focus and streamline the data gathering process, the study benefited from pre-structured qualitative data collection. The research questions were wellspecified prior to the field work. The modeling of the case studies, the poverty mapping to choose the interviewees, and the elaboration of the interview guides with a defined set of specific questions were undertaken before any data were collected. ${ }^{37}$

\footnotetext{
${ }_{37}$ See Annex 1 for the Interview Guide for Oportunidades beneficiaries, Annex 2 for the Interview Guide for Bolsa Família beneficiaries, and Annex 3 for the Interview Guide for non-beneficiaries of both programmes.
} 
Figure 3.2 Map of Mexico, showing Campeche

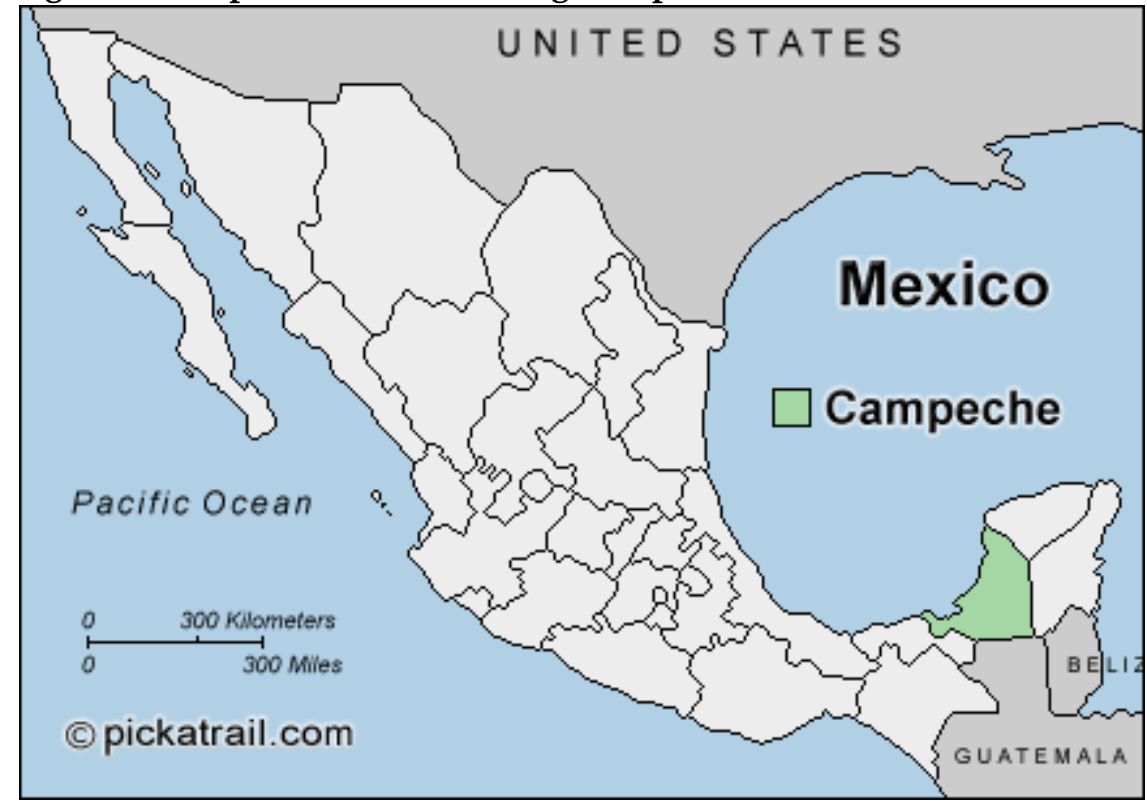

Source: Pickatrail.com

Figure 3.3 Map of Brazil, showing Ceará

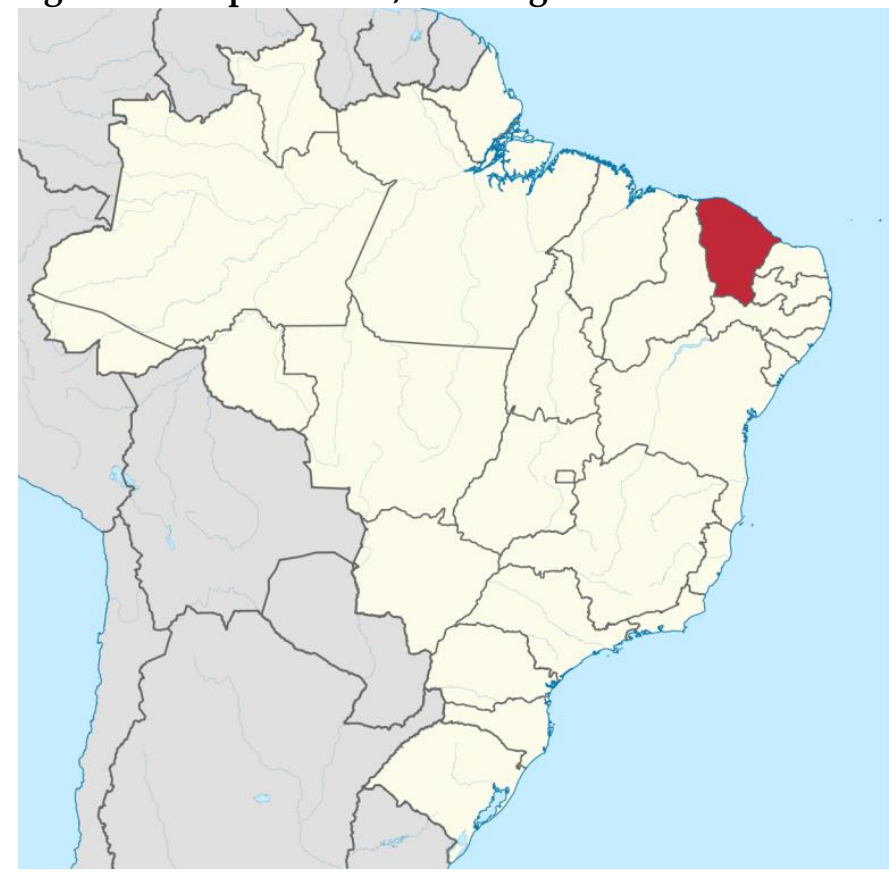

Source: Wikipedia. 


\subsubsection{Data Collection}

For this study in-depth, semi-structured interviews were conducted with beneficiaries and non-beneficiaries of the Oportunidades programme in Mexico and the Bolsa Família programme in Brazil in 2012. In each community, interviews were conducted with 10 beneficiary women (treatment group) and 10 nonbeneficiary women (control group). In total, 120 women were interviewed, 60 per country. The age ranged from 15 to 60 years. The interviews were conducted faceto-face in Campeche from April to June 2012, and in Ceará from October to December 2012, which provided enough time to get to know the communities, create trusting relationships with the beneficiaries, and obtain the number of planned in-depth interviews.

Both open-ended and closed questions were asked because the goal was to examine women's own perspectives and experiences with CCTs and gather qualitative information about women's empowerment related to transfer receipt. ${ }^{38}$ The qualitative approach (asking open-ended questions) is well-suited to explaining and understanding human phenomena in-depth rather than focusing on numbers (Miles and Huberman, 1994; Blumberg et al., 2008: 192). Qualitative research helps emphasize nuances, sequence and multiple perspectives (Stake, 1995: xii), which is why the method used for this study consists of in-depth interviews, observation and analysis of relevant policy documents. The closed questions asked to study participants in the field yielded information about interviewees' reproductive health, labor market participation and intra-household decision-making, and the general experience of the beneficiaries regarding CCTreceipt.

To locate the study participants in Mexico, we first contacted the Ministry of Social Development (Secretaría de Desarrollo Social) in Campeche. They gave us information about the poorest neighborhoods in the city and the address of the health centres in these neighborhoods. Once we had obtained this information, we went to the health centres and found out the dates when there were Oportunidades talks to the beneficiaries. Furthermore, we also found the address of community centres where both beneficiaries and non-beneficiaries met to engage in some activities. We attended the educational talks and at the end of such talks, asked the participants if they had time and interest to be interviewed. We explained the objective of the research and our affiliation to them. Usually, we obtained one or two interviews per meeting. These women also referred us to the community centres and to other women in the neighborhood (snowball sampling).

\footnotetext{
38 See Annexes 1, 2 and 3 for the interview guides.
} 
In total, we interviewed 25 women (out of 120) who had been referred to us by other women.

The sample was purposeful: we interviewed women with children, living in extreme poverty, receiving the CCTs or not, but living in the same neighborhoods (poor neighborhoods in Mexico and favelas in Brazil). The non-beneficiaries were women also living in extreme poverty, but who did not receive the transfers due to enrollment problems -such as being enrolled but never actually receiving the money-, personal preferences -lack of time or interest to follow the enrollment process and conditionalities- or because their income was slightly above the CCT's limit.

In Brazil, we contacted the Ministry of Social Development (Ministério do Desenvolvimento Social e Combate à Fome) in Fortaleza, and through them we found out which were the poorest favelas in the Ceará State. A programme officer also provided us with the contact of a favela university student who was interested in the research and who became our research assistant in Brazil. The research assistant helped to locate the health and community centres in the favelas, accompanied us to them and supported us with the translations of the interview guides and the communication with the interviewees from English to Portuguese and vice versa when necessary. We interviewed beneficiaries and non-beneficiaries in the health and community centres and using snow-ball sampling. In Quixadá, we also went from door to door. We could recruit the non-beneficiaries because they lived in the same neighborhoods and attended the same community centres as the beneficiaries.

The study participants were provided with detailed information about the research and the type of interview they were participating in. We had printed interview guides which we used during the field work. Notes by hand were taken in the printed interview guides and in some cases where the interviews took longer than one hour, the interviews were recorded. During the field work a field journal was kept with some extra details regarding the interviews. There some patterns observed in the data started to be defined. Furthermore, we started to transfer the field notes to Word. At the end of each day we also transferred the answers from the interviews to an Excel file. For this study, it was not necessary to go through an ethics review process at the university; however, in all cases confidentiality and anonymity were guaranteed. The interviews were voluntary and lasted between 45 minutes to one hour. In a couple of occasions interviews lasted two hours. We did not provide any kind of incentive or reward to the participants, so they participated just because they wanted to help. The interviews in Mexico were conducted in Spanish and the interviews in Brazil in Portuguese, with the support of the research assistant. 
In the interviews, participants' demographic data were collected, detailing age, civil status, education level, number of children and number of people in the household. In addition, the interview guide contained (open-ended and closed) questions about three main areas: 1) labour market participation, 2) domestic decision-making-including mobility and reproductive health, 3) and self-esteem and self-worth. For the beneficiaries of the CCTs, the interviews had an extra area regarding the usefulness of the programme and the effect they considered it had on their lives. The collected quantitative evidence allowed us to see whether or not there was an effect of CCTs (the yield were binary data based on yes/no answers). The qualitative information gathered allowed us to find out about the experiences of the women regarding CCTs' receipt, the processes of empowerment, what the barriers to empowerment consisted of, what employment/working meant to women, why they were able to make decisions in some areas (such as about issues related to children) and not others, and how the CCTs changed women's values and behaviours.

For chapter 4, the interview topic of labour market participation was used. The questions asked to all the interviewees (both beneficiaries and non-beneficiaries) regarding labour market participation were the following: 1) do you have a paid job? If yes: is it full-time or part-time? is it formal or informal? and for beneficiaries only: 2) did you have it before getting the transfers or after getting them? If not: did you have a job before the transfers? did you stop working after receiving the transfers? If so, why? and 3) would you like to get a paid job? and if so, why? Finally, both beneficiaries and non-beneficiaries were asked 1) if they used to have a paid job, and 2) if they would like to get a paid job, and if so, why. The interviewees could elaborate and express their own ideas. This allowed for deeper responses and to obtain a better understanding of the interviewees' reasoning regarding paid employment.

We only asked the mothers of the households these questions regarding their own labour situation. We did not include questions regarding men's or children's labour market participation because the research in this area focused on the qualitative narrative behind these women's decision to work or not.

For chapter 5, the topical area of intra-household decision-making was covered. The analysis in this chapter focused on the findings regarding the intra-household decision-making process for both beneficiaries and non-beneficiaries. The questions for this chapter in the interviews were distributed into five areas of decision-making and assessed whether women could make household decisions related to the following areas: 1) expenditure, 2) children's issues, 3) personal decisions, 4) reproductive decisions, and 5) mobility. 
The questions on decision-making were phrased in terms of whether or not the mothers could make certain decisions within the household and if so, how. In the area of expenditure, the questions focused on: 1) expenditure on children, 2) food expenditure, 3) durable purchases, 4) personal items, and 5) money saved. In the area of children's issues, the questions focused on: 1) school attendance, 2) attendance at health care, 3) purchase of clothing and school items, and 4) purchase of medicines. In the area of personal decisions the questions focused on: 1) women's ability to choose occupation, 2) their ability to participate in activities, and 3) their ability to choose friends. Regarding reproductive decisions the questions were on: 1) the use of contraceptive methods, 2) control over sexual relations, 3) control over child-bearing decisions, and 4) attendance at health checkups. Finally, regarding mobility, interviewees were asked whether or not they could: 1) leave the house alone without permission, 2) leave the house alone with permission, 3) leave the house accompanied without permission, 4) leave the house accompanied with permission, 5) meet female relatives, 6) meet female friends, 7) meet male relatives, and 8) meet male friends. In all areas, women were asked to elaborate on their responses about why they could or could not make decisions in the aforementioned topics. In order to find out about the gendered intra-household decision-making process, open questions were asked about: 1) who makes most decisions in the household, 2) which decisions are made by the wife, and 3) which decisions are made by the husband. Study participants were asked to elaborate when necessary.

Finally, for chapter 6, the interview areas of feelings of self-worth and women's own perceptions of empowerment were used. The analysis in this chapter focused on the findings about the psychological dimension of empowerment, focusing on the interviewees' own perceptions and experiences of empowerment and selfworth. Furthermore, questions were asked about beneficiaries' perceptions of the effect and meaning of Oportunidades and Bolsa Família on their lives. The interview questions in these areas were differentiated in two categories: a) the area of women's own perceptions of self-worth and empowerment, and b) Oportunidades' and Bolsa Família's effects on their lives. The questions were openended and the interviewees could express their own ideas. This allowed us to have richer responses and to obtain a better understanding of the process of empowerment for the women interviewed in these communities.

In the area of women's own perceptions of self-worth and empowerment, beneficiaries and non-beneficiaries were asked questions regarding: 1) who makes most decisions at home, 2) women's own opinions about being valued in the household, and 3) women's perceptions of their own opinions having the same weight as their husbands' opinion. Regarding the area of Oportunidades' and Bolsa Família's effect on their lives, only beneficiaries were asked about: 1) 
attendance at educational talks, 2) whether they consider such talks useful, 3) things learnt from the talks, 4) change of habits as result of the talks, 5) general change of behaviour, and 6) change in their feelings of appreciation since receiving the transfers.

Using the lens of empowerment, the research on this chapter focused primarily on women's feelings of self-worth and empowerment -of both beneficiaries and nonbeneficiaries, and on the perspectives of beneficiaries with regard to changes they perceive in their lives, related directly and indirectly to features of Oportunidades and Bolsa Família. This area of analysis examined, among others:

1) feelings of self-worth and opinion valued at home;

2) changes women describe with regard to freedom of movement, selfconfidence and "opening their minds;"

3) adult education that women want for themselves in order to improve their lives; and

4) changes in women's attitudes and behaviors as a result of the CCTs.

\subsubsection{Sample Description}

The interviewees were mothers between 15 and 60 years old (see Figure 3.4), either receiving Oportunidades or Bolsa Família -treatment group-, or not -control group. All of them were living under the poverty line (1.25 USD/day). Their civil status was: married/living together, divorced/separated or widowed. The number of children the women had varied from one to 10 (see Figure 3.5) and the number of people living in the household varied from two to eight (see Figures 3.6). Their education level varied from not having attended school at all and being unable to read or write, to having finished high school and university (see Table 3.1). In Mexico, most of the beneficiaries had not completed elementary school and the non-beneficiaries had completed junior high school. In Brazil, most of the beneficiaries had not completed elementary school and the non-beneficiaries had mostly completed elementary school. 
Table 3.1 Sample demographics

\begin{tabular}{|lcc|}
\hline Sample characteristics & Number (N=120) & Percentage* $^{*}$ \\
Marital status & & \\
Married & 83 & 69.1 \\
Living together & 17 & 14.2 \\
Separated/divorced & 16 & 13.3 \\
Widowed & 4 & 3.3 \\
& & \\
Mean Number of Children & 3.23 & N/A \\
& & \\
Education & & 3.3 \\
None & 4 & 23.3 \\
Elementary incomplete & 28 & 31.7 \\
Elementary complete & 38 & 3.3 \\
Junior high school incomplete & 4 & 30.8 \\
(secundaria incompleta) & & 4.2 \\
Junior high school complete (secundaria) & 37 & 3.3 \\
High school (preparatoria) & 5 & \\
University & 4 & N/A \\
& & \\
& & \\
Mean number of people in household & 4.93 & \\
\hline
\end{tabular}

* May not total 100 percent due to rounding

Source: Author's own research

Figure 3.4 Age of interviewees (frequency)

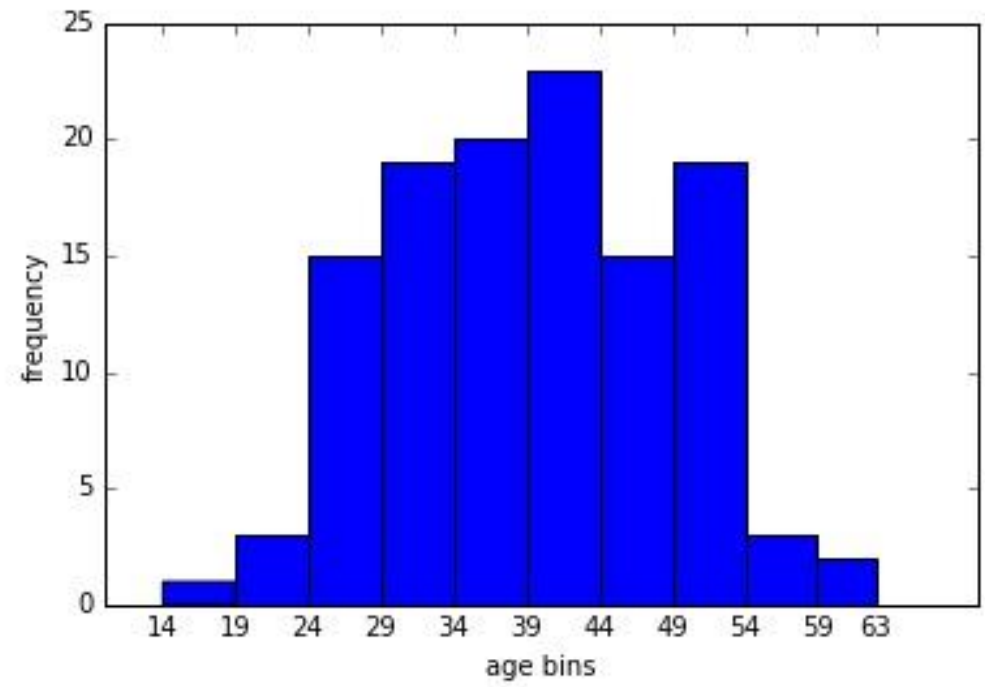

Source: Author's own research 
Figure 3.5 Women's number of children (frequency)

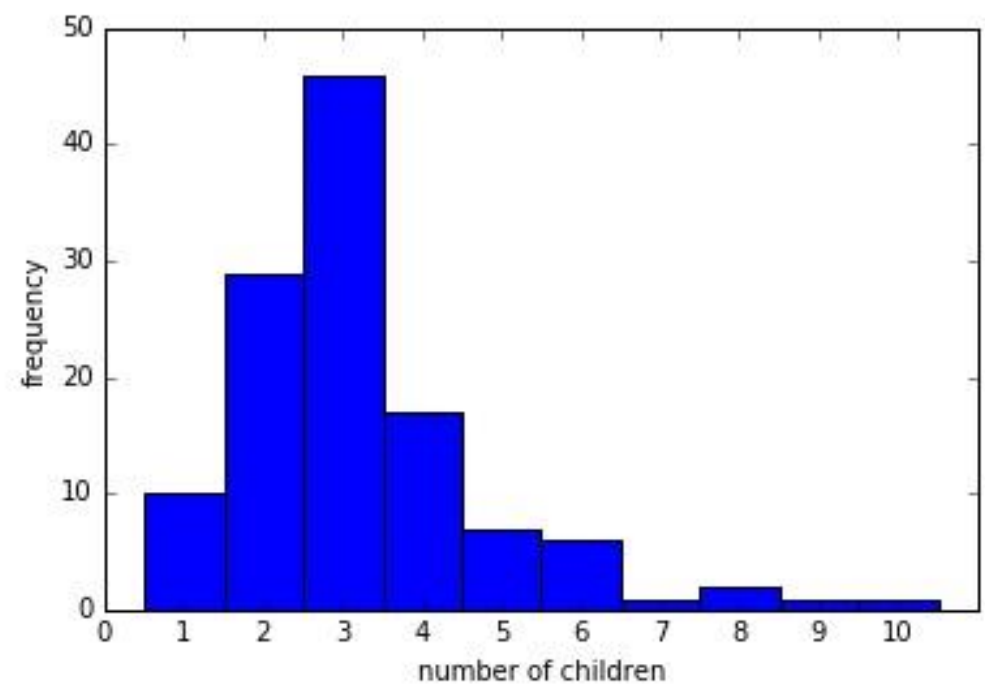

Source: Author's own research

Figure 3.6 Number of people living in the household (frequency)

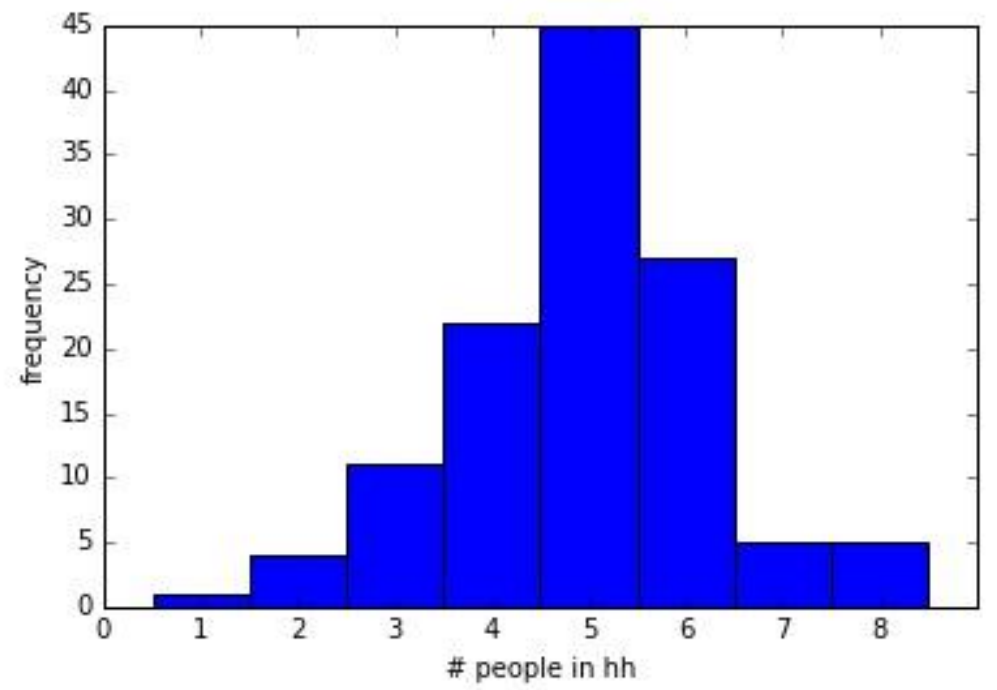

Source: Author's own research 


\subsubsection{Data Analysis}

After undertaking the field work in Mexico and Brazil, we went back to Maastricht and continued the process of data analysis. For this purpose, we first went through all the interviews and the field journal, and looked for main themes and patterns in the data. We developed codes based on comparing the data. Some of these codes were: work pride, desire to work, importance of education, lack of childcare, lack of education, desire to improve their children's future, control over food expenditure, alcoholism, domestic violence, drug abuse, machismo, etc. After arriving at the most concise descriptions of the data, the interviews were transferred into a main Excel file containing all the information regarding the interviewees (age, civil status, education level, number of children, and number of people in the household) and their answers in all areas of the interview (labour market, domestic decision-making, and self-worth). Afterwards, the data was analysed and tables were elaborated based on the beneficiaries and nonbeneficiaries' responses in the different areas of the study, namely: labour market participation (empirical findings in chapter 4), intra-household decision-making (chapter 5), and self-worth and perceptions of CCTs' effect on their lives (chapter 6).

\subsection{Limitations}

The following procedures were employed to increase the reliability of the data and validity of the findings (see Maxwell, 2005): all the notes and transcripts were double-checked for errors and accuracy both during the transcription and afterwards. By conducting interviews with many individuals in similar contexts, we could see patterns emerge and develop codes grounded in the data. In the text, multiple quotes were provided for the themes found in the data. Furthermore, the data material was triangulated by comparing it to previous research.

One of the limitations of this research is that it is based on interviews and sometimes the researcher's presence during data gathering can affect the subjects' responses (Maxwell, 2005). This bias was minimised by assuring the interviewees that we were independent researchers who were not linked to the government or any evaluation committee and could therefore in no way influence their access to the transfers.

Furthermore, the implications of qualitative research could be difficult to generalise or replicate because they can be linked only to certain contexts. However, since conditional cash transfers are almost always given to families living in extreme poverty, there are characteristics that are general to this vulnerable population, such as low education levels, low income levels, etc. And in 
this sense, policy considerations can be extracted which would benefit the population receiving the transfers in any country. According to Yin case studies aim for analytic generalisation, not statistical generalisation: "previously developed theory is used as a template with which to compare the empirical results of the case study" (2014: 38).

The main limitation of the findings is that they are based on small, nonrepresentative samples in Brazil and Mexico; our findings can therefore not be generalised to the populations of women CCT beneficiaries and non-beneficiaries in these countries (or other countries). However, this research contributes to the existing scholarship on the empowerment consequences of CCTs on women living in extreme poverty because it has led to conceptual development, which can be useful in more representative research studies assessing the gendered empowerment effects of CCTs in the future. In addition, the knowledge derived from this study can help further develop policy recommendations and conduct programme evaluations (Maxwell, 2005; Yin, 2014). 


\section{Chapter 4. CCTs and Women's Participation in the Labour Market}

\subsection{Introduction}

In the last decades, gender and development issues have attracted the attention of policy makers, international organisations, and economists, among others. Governments have targeted programmes devoted to the formulation of public policies that incorporate gender issues, such as conditional cash transfer programmes (CCTs). Moreover, most international organisations have integrated a gender approach into their development strategies to enhance women's participation in the economic development process. The recognition of differentiated demands, priorities, constraints and roles of the male and female segments of the population has started to influence public policy making and development agendas, included those related to labour and financial markets.

Since the early 1990s, the number of women joining the labour force in Mexico and Brazil has dramatically increased, and gender differences in labour force participation have decreased in both urban and rural areas. Female participation in the self-employment sector has also substantially increased, especially in nonagricultural sectors. For example, from 1991 to 1995 in Mexico, women accounted for $68 \%$ of the rise in non-agricultural self-employment. In the rural areas, female non-agricultural self-employment increased by almost $90 \%$ during the same period. However, gender differences in labour force participation are still substantial. According to Pagán and Sánchez (2000) only 29\% of women (compared to $87 \%$ of men) are employed. In contrast, the self-employment rates of men and women are very similar-about $30 \%$ of working men are self-employed compared to $29 \%$ of working women.

Drawing on Pagán and Sánchez (2000), conceptually, the gender differences in labour participation and the incidence of self-employment could arise from 1) endowment inequalities (i.e. women having less schooling and work experience than men) and gender differences in other productivity-related characteristics, and 2) structural labour market supply and demand factors. On the supply side, structural factors are influenced by household demographics as well as gender differences in employment preferences, time constraints, and work opportunities, among other matters. On the demand side, structural factors are influenced, for instance, by labour legislation that raises the cost of employing women relative to men, exclusionary practices by male-dominated trade unions or employer preferences. These demand factors, in turn, can feed back into labour supply 
decisions by affecting the inter-temporal return of joining the labour force, female perceptions on the value of being employed, and ultimately, the decision to join the labour market, the sector choice, and investments in schooling (Pagán and Sánchez, 2000).

The separation of the role of structural and endowment factors has important public policy implications when designing policies attempting to reduce gender inequities in labour market outcomes. The relative importance of each component will indicate whether policy makers should focus their attention on reducing gender-related inequalities in productive endowments or in attempting to correct gender-based labour market structural differences.

The focus of this chapter is on women, conditional cash transfers, and the labour market. The objective of the chapter is to analyse women's participation in the labour market and to define whether there is a difference in this participation as a consequence of receiving conditional cash transfers (CCTs). We wanted to find out if conditional cash transfers (in specific Oportunidades and Bolsa Família) enable women's labour market participation, or if, on the contrary, as criticism suggests see Kabeer, Piza and Taylor, 2012, they hinder such participation. Some quantitative studies have been undertaken regarding the impact of CCTs on women's labour market participation (see Oliveira, 2005; Maluccio, 2007; Attanasio et al., 2008; Foguel and Barros, 2008; Skoufias and Di Maro, 2008; Alzúa et al., 2009; Angelucci and Di Giorgi, 2009; Tavares, 2010; Teixeira, 2010; and Novella et al., 2012, among others). However, no qualitative research has been undertaken to find out the motivations behind CCT recipients' choices regarding labour market participation and the effect CCTs may have on these motivations. This study attempts to fill this knowledge gap, using qualitative data collected during fieldwork in the states of Campeche, in Mexico and of Ceará, in Brazil to examine what motivates CCT recipients, what work means to them and what barriers to working they experience.

The findings suggest that the consequences of CCTs are two-fold: they can act as both disincentives and incentives to women's labour market participation. The research found that a few beneficiaries -in Brazil- stopped working because the CCT substituted for earned income. However, it was also found that CCTs may have an "employment trigger-effect"-some women started working as a result of receiving the CCTs. Furthermore, it was found that many women were strongly motivated to work, but that they perceived and experienced a trinity of barriers consisting of 1) lack of child care, 2) lack of education, and 3) old age (i.e. lack of energy and employer discrimination towards older women). 
This chapter is structured in the following way: the second section provides the theoretical underpinnings of the impact of cash transfers on labour supply and presents a review of the empirical literature for countries in Latin America. The third section presents the research methods and data found in the field work for this research. The fourth section presents a discussion of the findings, and the fifth and final section states possible policy implications and presents concluding remarks.

\subsection{Literature Review}

CCTs combine short-term poverty alleviation (through cash transfers) with longterm objectives through incentives to human capital accumulation (school attendance, health check-ups, improved nutrition, and reduction of child labour). The spread of CCTs throughout Latin America and the world has made them a permanent aspect of social policy in the developing world for the foreseeable future. Moreover, the constantly growing literature on their evaluation has created a wealth of knowledge of their effect on the main target outcomes: educational and health results, nutrition, poverty reduction, and child labour. According to the results from a number of evaluations, cash transfers, especially when combined with conditionalities, have proven successful in increasing welfare and human capital accumulation in recipient households, and lowering child labour (Rawlings and Rubio, 2005).

\subsubsection{Cash Transfers and Labour Supply}

Welfare policy and work incentives, and their combination, have received less attention in the development literature. However, this line of research has potentially relevant payoffs for our understanding of labour markets in general, and especially in how they interact with the development process. Labour supply decisions are crucial to understanding the income-generation process of the poor and to assess potential poverty traps (Alzúa et al., 2009). Moreover, these studies can shed light on labour markets in developing countries: households make decisions amidst a complex setting characterised by unemployment, labour informality, migration, cultural norms and high transaction costs in general.

The overall design of CCTs is not directly related to adult employment in beneficiary households. There are no work requirements or restrictions, and households can earn labour income without losing the benefit. Nonetheless, as Alzúa et al. (2009) point out, this lack of work requirements does not mean that the programmes are neutral in terms of adult labour supply and participation incentives. Since CCTs modify the income of the household and, possibly, the 
allocation of time through their impact on children's work and school enrollment, there is potential for effects on adults' labour supply in beneficiary households.

Most of the existing literature on CCTs' effects has focused on educational performance, health and nutritional outcomes of children. However, less attention has been paid to the indirect effects cash transfers could have on adult's behavior, especially regarding the effects of CCTs on adult labour supply. Criticism suggests that while cash transfers are necessary to accomplish improvements in consumption, education, and health, they can also generate incentives to reduce work supply among adults, since this payment can be thought of as a pure income effect (Fernandez and Saldarriaga, 2014). However, experimental evidence has shown small effects of CCTs on labour supply of adults from beneficiary households (Parker and Skoufias, 2000). This literature relies on comparisons between beneficiaries and non-beneficiaries to estimate the so-called average treatment effect of CCTs on labour supply.

Economic theory suggests some ways in which CCTs can affect work decisions within recipient households. The potential effects of benefit transfers can be explained based on the standard static model of labour supply. In this model, individuals maximise between consumption and leisure facing a budget constraint, which is composed by labour (wage) and non-labour (initial wealth and monetary or in-kind transfers) income.

As pointed out by Alzúa et al. (2013), CCTs have four potential channels through which adult labour supply could be impacted:

1) Cash transfers represent an increment in non-labour income. Given that no conditions are imposed with regard to labour participation of beneficiaries, the transfer is a pure income effect, and therefore, both employment and working hours would be expected to decline.

2) Programme conditions can also alter working behavior of adults. For instance, most of the conditions attached to cash transfer programmes imply school enrolment and a maximum number of days accepted for children to be absent from school. This increase in school attendance of children could allow parents, in particular mothers, to increase labour participation and working hours as well, since they avoid allocating time to childcare.

3) In situations where child labour is crucial in determining households' budget constraint, increasing school attendance could also affect adult labour supply.

4) Cash transfers can also affect local markets by a trickle-down effect, and thereby have an indirect impact on non-beneficiaries. For example, using a sample from Oportunidades, Angelucci and De Giorgi (2009) found that consumption of ineligible households increased in villages where the programme was randomly implemented. 
The sum of these channels suggests that the general effect of CCTs on adult labour participation is theoretically ambiguous: the rise in non-labour income might increase or decrease hours of work, depending on whether leisure is a normal or an inferior good. ${ }^{39}$ If leisure is assumed to be a normal good, we could expect a negative impact on labour supply. However, some channels introduce further uncertainty on the sign of the overall effect. On the one hand, even if leisure is considered a normal good, the presence of fixed hour or money costs (such as commuting or child care) implies that a lump-sum transfer might increase labour supply. In addition, increased children's school attendance might free time previously spent in childcare, further reducing the cost of work. On the other hand, the increase in income through cash transfers might be reduced in net terms by the lost income from the reduction of child labour, and might even result in a net reduction of the total household income. This effect might mitigate any potential disincentive in the labour supply of adults, and might even induce a positive response to compensate for the lost child's labour income.

This research did not focused on finding out whether or not all adults in the beneficiary households increase or decrease their labour participation. The goal was to find out whether mothers, in particular, change their labour market participation as a consequence of receiving CCTs. For this reason, theoretical considerations of models of household labour supply added useful insight. There are two models associated with household behavior. The first one, the "unitary" behavior model, assumes that family members act as if they are maximising a single utility function. Maximising a single utility function implies that, regardless of who receives the welfare income, each of the family members would benefit from the monetary transfer through an intra-family allocation process (Becker, 1981; Browning et al., 1994; Lundberg and Pollak, 2003; Browning et al., 2006).

Moving beyond from the "unitary" model, the second model-the "collective" household model-posits a utility function for each agent in the household. "Collective" models suggest that the household allocation of resources results from the interaction of the utility function of different agents in the household, which are aggregated into a household's utility function through the weighted average of the different agents' utilities (Chiappori, 1992; Browning et al., 1994; Lundberg and Pollak, 2003; Basu, 2006; Browning et al., 2006). Weights consist of distributional factors reflecting individuals' distribution of power in the household decision. Among the main factors determining power distribution are unearned income

\footnotetext{
${ }^{39}$ In economic theory, normal goods are any goods for which demand increases when income increases, and falls when income decreases but price remains constant, i.e. with a positive income elasticity of demand. Inferior goods are goods that decrease in demand when consumers' income rises or rise in demand when consumers income decreases.
} 
(Hoddinott and Haddad, 1995), relative education (Frankenberg and Thomas, 2003), and assets brought to marriage (Fafchamps and Quisumbing, 2002).

In contrast to the "unitary" model, in "collective" models the identity of the transfer recipient matters. For example, unearned income under the control of women and maternal education has found to have a bigger effect on children's health and educational outcomes relative to the equivalent for fathers (Thomas, 1994). Targeting women as the recipients of CCTs has the objective to maximise the effects of the programmes. This design feature might also modify the allocation of a household's resources through the impact on the intra-household power distribution. The expected effect of maternal bargaining power on parental labour supply is ambiguous and depends, among other factors, on women's preferences. On the one hand, an increase in women's bargaining power might lead them to decrease their supply of labour and either lead to an increase in their consumption of leisure or of time dedicated to household chores, including accomplishing the conditionalities of the programme (i.e. bringing children to school or health centre). On the other hand, having more power might allow women to overcome traditional gender roles and supply more labour. In the next section, some previous findings regarding CCTs in Latin America and their impact on labour market participation will be reviewed.

\subsubsection{Previous Findings from Latin America on the Impact of CCTs on Women's Labour Market Participation}

The literature addressing the impact of CCT programmes on different variables of interest is vast and continuously growing. In this section, international evidence on the effects of CCTs on labour market participation is presented. With respect to Oportunidades' impact on the time allocation of individuals benefiting from the programme, Parker and Skoufias (2000) found evidence that it reduced the labour force participation of children, both for boys and for girls. With respect to adults, the results showed that there was no reduction in the rate of participation in the labour market.

Skoufias and Di Maro (2008) found no significant effect of Oportunidades on adults' labour supply. In particular, the results of their study showed that there was no reduction in participation in the labour market. However, there is evidence that soon after they began receiving the cash transfers, individuals used part of the subsidy to seek work in remunerated activities and to reduce participation in less profitable family ventures. This impact, however, disappeared with time. Alzúa et al. (2009) estimated the effects on the labour market of three CCTs, including Oportunidades, the programme implemented in Nicaragua called Red de Protección Social (RPS-Social Protection Network), and the Programa de 
Asignación Familiar (PRAF-Family Allowance Programme) implemented in Honduras. The empirical results indicated that none of the three programmes led to significant changes in adults' participation in the labour force. However, the analysis found a significant reduction in adult working hours in Nicaragua and a positive and significant effect on the wages of men in eligible households in Mexico.

Recently, several studies have tried to diagnose the effects of the Bolsa Família on children's school attendance and on youths' and adults' labour supply in Brazil. Pedrozo (2010) found that the programme led to a negative impact on adults' labour supply, especially the one of single or divorced mothers, and found that the Bolsa Família selection rule can be circumvented by the voluntary reduction of labour supply. This impact could be explained by the fact that single or divorced mothers may have spent more time doing household chores instead of working outside the house. Tavares (2010) found evidence that mothers receiving Bolsa Família showed a $5.6 \%$ increase in the probability of participating in the labour market; they also extended their weekly working hours by $1.6 \%$ more than nonbeneficiary mothers. However, higher benefits were associated with a lower probability of participation and lower weekly working hours. Thus, it may be concluded that there is indeed a negative income effect-i.e. there is a reduction in participation in the labour market as a result of receiving the benefit, which is overcome by a positive substitution effect. In other words, adults must work more to compensate for the reduction in child labour.

In a similar study, Ferro and Nicolella (2007) found that participation in a CCT programme did not affect the probability of parents participating in the labour force. However, Bolsa Família led to some changes in working hours, with the effect being positive for mothers in urban areas and negative for mothers in rural areas and fathers in urban areas. Furthermore, the authors found that the programme was more effective in reducing female child labour than male child labour. Medeiros and Costa (2008) showed that, while the rate of participation in the labour market of people in beneficiary households was $73 \%$ for the first decile of the distribution, $74 \%$ for second and $76 \%$ for the third, the rates were $67 \%, 68 \%$ and $71 \%$, respectively, for those living in households with no beneficiaries. According to Teixeira (2010), in order to perform an accurate causal analysis of the effects of Bolsa Família, the budget shock should be taken into account. The budget shock is defined as the ratio between benefit and household income. It should be taken into account that the results obtained showed a reduction in the number of weekly working hours that could vary between 0 and 3.5 hours. However, Teixeira argued that the effects of Bolsa Família on labour supply were not equal for the different ratios of the benefit relative to household income. The effects were stronger for the benefits of R\$15 (4 USD), R\$50 (13 USD) and R\$60 (16 USD), for 
households including only one child and for those whose per capita income was less than R $\$ 20$ (5 USD). Moreover, an analysis showed that the supply elasticity of working hours varied by gender and across occupations. Among occupations, formal employment was less elastic and self-employment had the highest elasticity.

Chitolina et al. (2016) found in their analysis that the Bolsa Família's impact on mothers and fathers did not show many significant effects. It is only possible to say that, in the estimation with control variables, the benefit had a positive (4.5\%) effect on the probability of the mother being employed. The participation of fathers in the labour force, and the working hours of mothers and fathers were not affected, even when the sample was separated by region. A systematic review by Kabeer et al. (2012) regarding the impact of CCTs on adult labour participation in Brazil pointed out that, overall, the evidence base for CCTs' impact on adult labour participation is weaker and less consistent than that for child labour. Oliveira (2005) used a 2005 survey to examine the impacts of Bolsa Família on various aspects of household behavior compared to households who did not receive any kind of cash transfer. Along with impacts on children's schooling and work, she examined impacts on adult labour supply, in terms of both proportions of adults who worked in the previous month and proportions who looked for a job in the previous month. The results showed that a higher proportion of adults in Bolsa Família households were likely to have worked in the previous month relative to those who did not receive any transfer-with the exception of the poorest families in the north- and mid-west region. At the same time, a higher proportion of adults in Bolsa Família households had been looking for a job in the previous month, particularly among lowestincome families, relative to members of the non-beneficiary group. Tavares (2010) estimated the impact of Bolsa Família on mothers' labour supply. Estimating the average treatment effect via a propensity score matching procedure, she found it to be between $-4.15 \%$ and $-8.96 \%$. Bolsa Família appeared to have reduced mothers' time spent working by $4 \%-9 \%$ per week.

Teixeira (2010) used the 2006 Brazilian National Household Survey to estimate the impact of Bolsa Família on adult labour supply. Her overall conclusion was that the programme had no impact on the probability of work for men or women (the extensive margin) and a small but statistically significant impact on hours worked a week (the intensive margin). There was thus little evidence of a disincentive effect. She also found that the elasticity of labour supply varied according to gender, size of the transfer and occupation. ${ }^{40}$ The likelihood of women working

\footnotetext{
${ }^{40}$ In economics, elasticity is the measurement of how responsive an economic variable is to a change in another variable. An elastic variable (or elasticity value $>1$ ) is one which responds more than
} 
was more responsive to the size of the transfer than the likelihood of men working, with the effect concentrated among those receiving between 14 USD and 21 USD (the transfers ranged from 4 USD to 45 USD per month). The impact on hours worked per week was to reduce it by 0.56 hours for men and 1.18 hours for women (1.3\% and $4.1 \%$ respectively). The reduction in time in market work translated into an increase in household work for women and leisure time for men. Men put in nine hours a week in housework compared to 24 hours by women. In terms of occupational patterns, those in formal work were least responsive to the transfer. Women in non-agricultural self-employment were most responsive, reducing their average labour supply by $2.1 \%$ per week. For men, no impact was shown in this occupation.

Foguel and Barros (2008) examined the impact of a number of CCT programmes in Brazil on adult labour supply at both extensive and intensive margins. Their analysis was based on a national cross-section household survey which is carried out annually for the same set of municipalities. They used data for the period from 2001 to 2005. They found little impact on female labour force participation rates as a result of programme participation and suggested that child care responsibilities might be inhibiting women's capacity to increase their labour force participation. There was a small but statistically significant increase in male participation rates: a $10 \%$ increase in CCT beneficiaries in the population of a municipality led to an increase of $0.05 \%$ in participation rates. CCT had a negative but negligible impact on female hours worked. Thus the impact of the programme was insignificant in terms of female labour force participation but negative in terms of hours worked: "since there are various channels through which these two effects may be connected it is difficult to offer an explanation for this result" (Foguel and Barros, 2008: 14). The effect on male hours was positive but not significant and household income levels did not affect any of these results.

In another study, Foguel and Barros (2010) found that the impact of Bolsa Família on female participation in the labour force is not significant on statistical grounds nor in terms of magnitude. This was observed for all females and for those below the median per capita income. As for males, there is evidence that the effect on the rate of participation is positive, though very small in magnitude. This result was observed for all males and for those below median per capita income. In terms of the supply of hours, the results indicate a small negative effect on all females but an insignificant impact on those living below median per capita income. The authors did not find significant impacts of the programme on the number of hours worked by males.

proportionally to changes in other variables. An inelastic variable (or elasticity value $<1$ ) is one which changes less than proportionally in response to changes in other variables. 
In Mexico, Skoufias and Di Maro (2008) analysed the impact of Oportunidades on adult labour force participation using several rounds of data between November 1997 (the baseline survey) and November 1999. Their research found that, irrespective of age group, participation in Oportunidades had little or no impact on adult male labour force participation. They also found some evidence that the transfers were initially used to shift men out of self-employment or unpaid work into waged work. Similar findings were reported for women, and there was little evidence of any impact on the leisure time of either men or women.

Kabeer et al. (2012) point out that most of the studies conducted regarding labour participation pointed to some negative (moral hazard) effect of CCTs on adults' behaviour, but overall the evidence is mixed. Their research suggests that the overall effect is $3 \%$, but it is not statistically significant at the $5 \%$ level (pvalue $=0.46$ ). The confidence interval suggests that CCTs could reduce adult labour supply by $5 \%$ or increase it by $12 \%$. In fact, the absence of an effect of CCTs on the labour supply of adults is predicted by the CCT rationale since, for most beneficiaries, the transfer had an income effect that was not big enough to allow poor households to trade off hours worked (or work participation) for extra leisure. Leisure was a luxury good that most of the beneficiaries' households could not afford. Consistent with the results of Skoufias and Di Maro (2008), the studies of Kabeer et al. (2012) conclude that CCTs often appeared to have more impact on the type of work that adults do, rather than whether they work at all, particularly in the case of women's time allocation. The size of the transfer also contributed to variation in impact.

Critics of Bolsa Família allege that it has a negative impact on labour force participation. However, evaluations found that the labour market participation rate of treated adults was, in fact, $2.6 \%$ higher than for non-treated adults. This impact was gendered: the participation rate of beneficiary women was $4.3 \%$ higher (Veras Soares and Britto, 2007). The reported impacts of CCTs on labour force participation vary across countries, but overall they do not show a negative impact. This is an important result. The Colombian Familias en Acción and the Mexican Oportunidades have had no impact on adults' labour force participation. Chile Solidario has had a positive and significant effect on labour force participation in rural areas. While Familias en Acción has had no impact on adults' participation, it has slightly diminished the participation of children 10-13 years old, and has had an even more pronounced effect on reducing their participation in domestic work. In Mexico, Oportunidades has contributed to a significant reduction of the proportion of children engaged in any kind of labour.

Notwithstanding the contrasting effects in some programmes, most CCTs do not seem to affect adults' labour supply. Fiszbein et al. (2009) suggest possible reasons: 
1) It may be due to the fact that the demand of leisure is inelastic to changes in income for CCT beneficiaries (and therefore, the transfer almost does not alter the labour supply).

2) It may be the case that CCTs have a negative net effect on household budget (reduction of income associated with reduction of child labour and increase in schooling costs, and small transfer amount).

3) It is possible that households consider the transfer as a temporary income source, therefore not risking their current income.

4) Finally, it might be that evaluating labour supply changes soon after the implementation of the programmes may lead to underestimate the long-term effects of CCTs.

In addition to looking at labour market responses in terms of participation and intensity of participation (working hours), some other studies have focused on the impact of CCT programmes on changes in economic sectors and activities. Lehmann (2010) finds that CCTs increased the marginal utility of leisure of beneficiaries in Mexico, reducing the time allocated to home production. While no evidence of changes in production is found, time allocated to the commercialization of home-produced goods changed, which according to the author may be an overlooked variable in studies that do not find any significant impact of transfers on labour supply. In addition, he reports that there is evidence that Oportunidades beneficiary households increased their participation in microenterprise activities and made larger investments in agricultural production activities, which are expected to have long-lasting effects on treated households. Skoufias and Di Maro (2008) find evidence that CCT transfers enable beneficiaries, at least initially, to change from low-paid family business jobs to salaried-jobs.

Most of the studies cited above use a "unitary model" of the household, leaving aside another dimension of the impact of CCT programmes on labour supply: the intra-household changes in the allocation of resources and time. The intrahousehold dimension offers a potential source of variability in household responses to CCTs that has not been explored in much detail in the empirical literature. In this respect, Parker and Skoufias (2000) show evidence that mothers in Oportunidades increased childcare, while Skoufias (2006) discusses quantitative and qualitative evidence that Oportunidades is associated with more participation of women in the household decision-making process, to a positive change of men's attitudes toward women, and to an increase in women empowerment. Novella et al. (2012) find that as bargaining power in the household becomes more balanced or shifts toward women, the labour supply of mothers seems to increase. They also show that women are more likely to be employed when they have more bargaining power in the household. These findings might suggest that more powerful mothers are able to overcome traditional gender roles and supply more labour. Regarding 
the fathers, they find that Oportunidades increases fathers' labour supply by two hours per week.

In a study by Alzúa et al. (2013), results indicate that the effects of CCTs on the labour supply of participating adults are, while primarily negative, small and nonsignificant. Even though they provided considerable transfers, the programmes did not reduce the labour supply substantially in the short term. However, the evidence also reveals the presence of other effects on labour markets. In the case of Oportunidades, there was a small positive effect on the number of hours worked by female beneficiaries, a sizeable increase in wages, especially among male beneficiaries, and a resulting increase in household labour income after the programme had been in operation for 2 years. These impacts can be attributed to changes in the labour supply of adults in eligible households and to the increased amount of time available to women as a result of higher school enrollment rates among children.

In summary, these studies show overall mixed evidence of CCTs' impact on women' labour market participation. Most of them (Parker and Skoufias, 2000; Skoufias and Di Maro, 2008; Alzúa et al., 2013) showed no significant changes in women's labour market participation as a result of Oportunidades' transfers. In the case of Bolsa Família, Pedrozo (2010) and Tavares (2010) showed that the transfers had a negative impact on adults' labour supply. However, Foguel and Barros (2008) and Teixeira (2010) found that there was no impact on female labour market participation rates. Finally, Oliveira (2005) and Tavares (2008) found out that mothers who received the transfers increased their probability of participating in the labour market.

\subsection{Methods}

As stated in chapter 3, the methods used in order to assess the effect of conditional cash transfers on the beneficiaries' labour participation and the perceptions of interviewees regarding labour participation are based on case study field work. Data for this study come from the qualitative analysis of semi-structured in-depth interviews with 120 beneficiaries and non-beneficiaries of the Oportunidades and Bolsa Família programmes, conducted in Mexico and Brazil in 2012. The findings of prior research mentioned in the previous section focused on quantitative information, hours worked per week and occupational patterns, among others. In this study, while information was gathered on these issues, the women's narratives behind their decision to work or not were also explored. This study fills a knowledge gap in this respect, since all previous research on this area has focused on the statistical effect of CCTs on labour market participation, but no research has been undertaken focusing on the women's reasons behind their labour market 
participation or lack thereof. These findings will focus on the experiences and perceptions of the interviewees-both beneficiaries and non-beneficiaries-, on the meaning work has for them, on the barriers they face, and on their reasons to work or not to work.

\subsection{Findings}

This section discusses the qualitative findings on labour market participation of female beneficiaries and non-beneficiaries of the Oportunidades programme in Campeche and the Bolsa Família programme in Ceará. The importance of this research resides in the qualitative information compiled during the in-depth interviews. Such information provides a deeper understanding of what drives the decisions of these women regarding whether to work or not, and the effects of CCTs on these decisions. It also helps us understand the nuances of their contexts.

\subsubsection{Labour Market Participation}

Figure 4.1 presents the main numeric results regarding interviewees' labour market participation or lack thereof, focused on whether they have a full-time or part-time job and if it is formal or informal. ${ }^{41}$

\section{Figure 4.1 Interviewees' self-reported labour market participation}

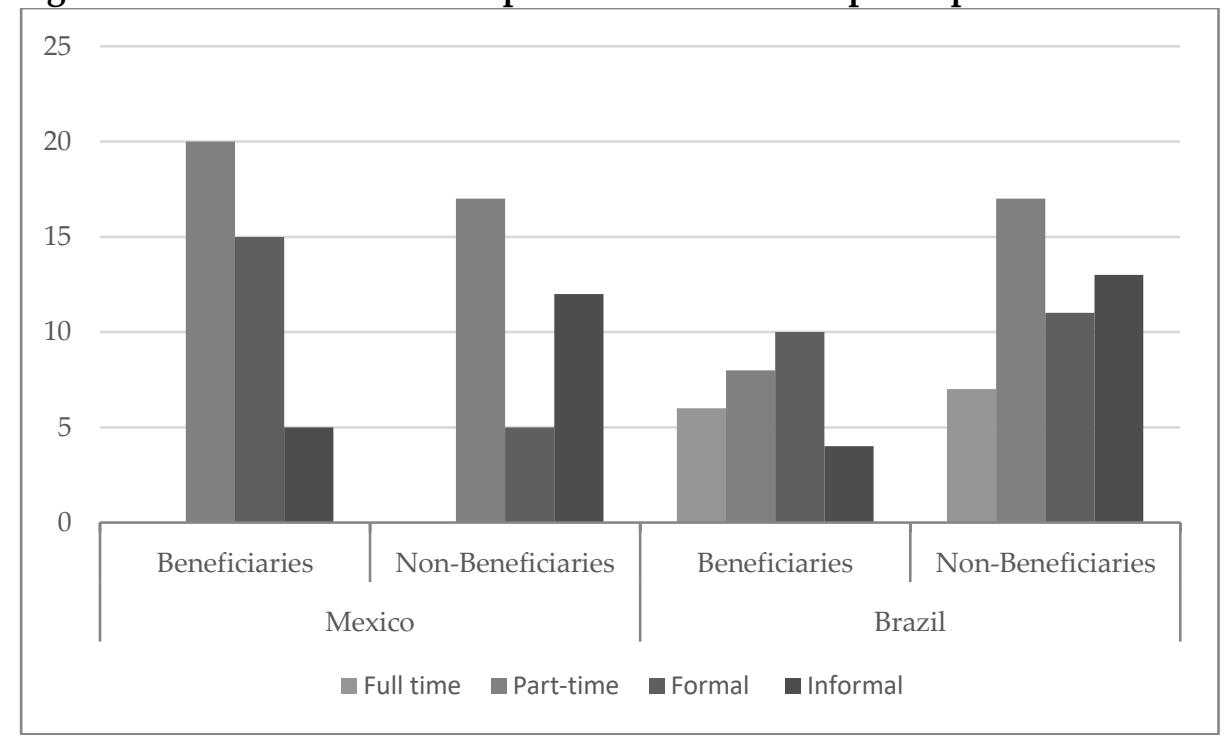

Source: Author's own data

${ }^{41}$ These results are condensed from Table A4.1 which can be viewed in detail in Annex 6 . 
The fieldwork data in Figure 4.1 shows that among the women interviewed in Mexico, $66.6 \%$ of the beneficiaries (20 out of 30 interviewees) in the state of Campeche have a paid job. None of them has a full time job, and $25 \%$ (five out of 20) have informal jobs. $56.6 \%$ of non-beneficiaries (17 of 30) in Campeche have a paid job. Among these women, all of them have a part-time job and only $16.6 \%$ (five out of 17) have a formal economy job. These results could be explained by the fact that beneficiary households have a lower income than non-beneficiary households and therefore the women beneficiaries need to work in order to support the family income. Of the working beneficiary women, 80\% (16 of the 20 employed women) were already working before getting the transfers and $20 \%$ (four women) got a job after starting to receive Oportunidades.

Among the beneficiary women who were not working (10 of 30 women interviewed), only three had had a previous job, and also only three wanted to work again (30\% of non-working women). Two of them (from Tenabo) stopped working when they had children to take care of them. Participant M14 (from Hecelchakán) stopped working four years ago, when her 15 year-old daughter got pregnant. M14 (36, 4 children) said:

"Working has always been very important to me. But my husband prefers me to be at home. I was working until four years ago, when my 15 year-old daughter got pregnant. After that, I decided to take more care of my children so the other ones wouldn't make the same mistake."

None of the non-working beneficiary women mentioned receiving Oportunidades as a reason to stop working once getting the transfers, contradicting criticism that says CCTs can provide incentives to reduce labour.

Data showed that in Brazil, 14 out of 30 beneficiaries had a paid job (46.6\%) and of these 14 working women, six had a full time job $(42.8 \%)$, and 10 of them had a formal job (71.4\%). 24 out of $30(80 \%)$ Bolsa Família non-beneficiaries had a paid job, and these women were the group with the highest rate of labour market participation of all the interviewees' groups. Of these 24, seven (29\%) had a full time job and 13 (54\%) had an informal job. Interestingly, beneficiaries in Mexico (20 out of 30) have a higher labour participation rate than non-beneficiaries (17 out of 30), but in Brazil, this figure is reversed: non-beneficiaries of Bolsa Família have a higher participation rate (24 out of 30 ) than beneficiaries (14 out of 30 ). These results could be explained because women beneficiaries in Mexico have a lower household income than non-beneficiaries and this pushes them to work. This situation is also linked to the CCTs employment trigger-effect which will be discussed later in this chapter. 
narrative of the women who stopped working is that they enjoyed working but stopped to care for their families, as Campeche non-beneficiary M38 (36, mother of two) said: "I used to work before getting married and my husband liked that. But I needed to stop working to take care of my children. Once they are a little bit older, I would like to go back to work to support the family income." The Oportunidades' transfers seemed to provide an opportunity for women with young children to use their time for child care instead of participating in the labour market.

Of all the interviewed women in Mexico, including beneficiaries and nonbeneficiaries, 23 out of 60 (38\% of all interviewees) were not working currently and from this 23, 18 (78\% of non-working women) did not express a desire to participate in the labour market.

Figure 4.2 shows that not all beneficiaries can or want to participate in the labour market. ${ }^{43}$ In Mexico, 10 beneficiaries out of 30 (66.6\%) were not working, and of the non-working women, seven of them had never worked and three quit their jobs when they had children in order to take care of them. In Brazil, among the beneficiary non-working women (16 out of 30), 13 out of 16 had some previous work experience and 10 of them said that their reason for stopping working was that they got married and had children and needed to care for their families. Six of the 16 non-working women mentioned that they wanted to work, and all of them mentioned they were waiting for their children to be older. However, this situation is complicated for mothers living in poverty because of childcare responsibilities, as beneficiary B10 (27, 3 children) from Fortaleza remarked:

"I want to work sewing dresses for my neighbours. However, I feel I cannot (work) because I would need to pay someone (to care for my children). All the money I would earn would be anyways spent paying someone else. My partner supports me to work, so we have more money, but I really feel in my situation it is not possible, because of the children."

\footnotetext{
${ }^{43}$ These results are condensed from Table A4.3 which can be viewed in detail in Annex 6 .
} 
Figure 4.2 Classification of working and non-working beneficiaries

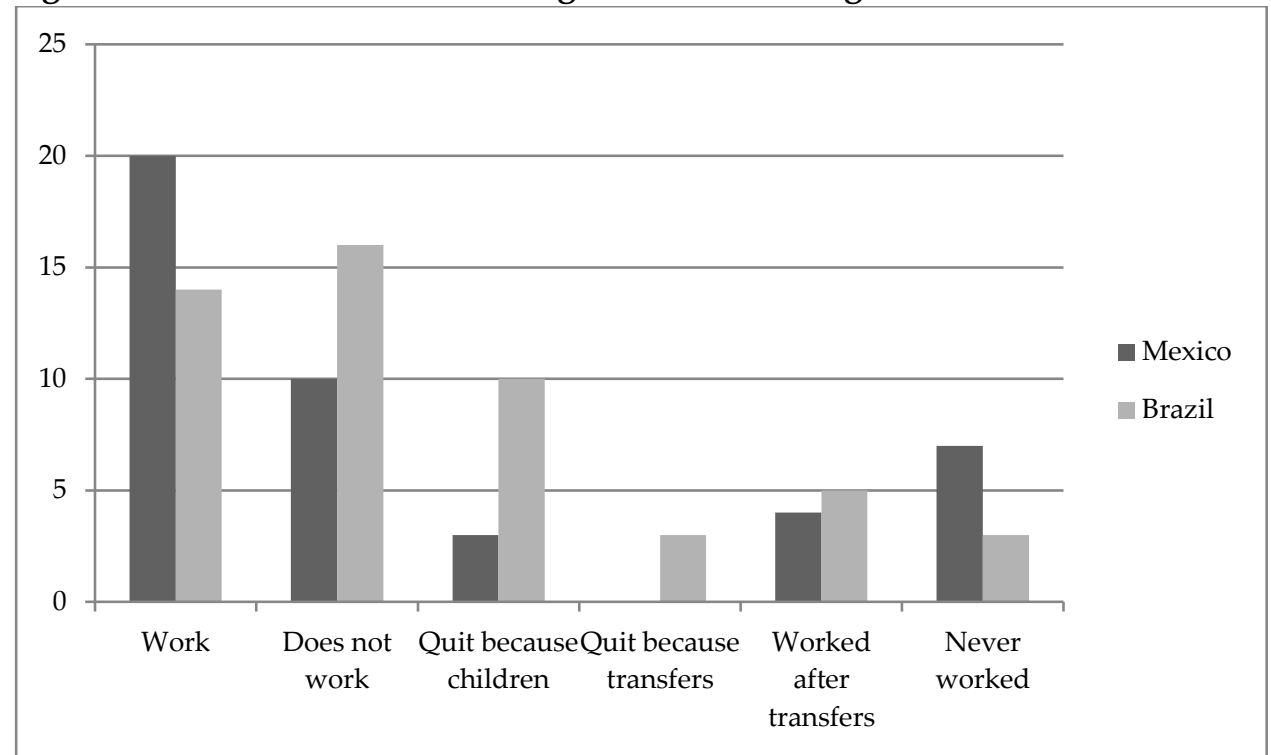

Source: Author's own data

\subsubsection{The Meaning of Work}

It is important to keep in mind the profile of the interviewees; they are mothers with families living in extreme poverty, with few years of education and in some cases, no education at all. Between $50 \%$ and $66 \%$ of them work, but mostly parttime and in low-remuneration and low-skilled jobs, such as domestic workers, cleaning ladies, doing laundry, etc. Most of them have between three and five children (and in some cases between seven and 10), many times from different husbands/partners, and they rely on their husband/partner's income to take care of their children. In many cases, the husband is physically aggressive (especially in Mexico), and in other cases they are drug users (especially in Brazil). Due to this situation, women feel sometimes trapped by their life circumstances and wish they could have access to income-generating activities, but at the same time, without neglecting their children's care.

This research showed that most of the interviewees mentioned that work is in itself a source of pride. Participating in the labour market and having the capacity to earn their own income make them feel more valuable as a person and in their households. In addition, they feel that they have more options and choices in their lives (i.e. leaving their husband, saving, investing in a productive activity). This situation influences their self-esteem and their perceived life satisfaction. 
Many beneficiaries had worked before and continued to work, regardless of Bolsa Família, and took special pride in their work. As beneficiary B20 from Quixadá (36, 7 children) stated: "It was my decision to work all my life, I didn't want to depend so much on my husband. He does grocery shopping, but I use my money for my things." Beneficiaries from the Mangue Seco community in Brazil shared these principles: "I have worked all my life since I was 17. I didn't stop, not even to sit down. I won't stop now just because of Bolsa (Família)." (B25, 40, 6 children),

"I was working before getting Bolsa (Familia). I never had time to be with my daughters. I started working when I was 12 to help my family, because my mom never worked. I didn't want my children to suffer like I did, so I have always worked to give them a better life." (B21, 33, 2 children),

"I want to work more to have more money but don't have time nor energy. I walk two hours to go to work and two hours to go back home. I live in Mangue Seco and work in Jericoacoara in a hostel. I walk four hours every day through the sand dunes. One time I almost drowned because the tide came up a lot. Look, my skin is all burned because of the sun." (B23, 46, 6 children)

\subsubsection{Motivation to Work}

As their motivation, this study found that women mainly are driven by the desire to make their own money (to have more income to spend or save), to be financially independent from their partners, and to give a better life to their children.

Among the beneficiary women in Brazil, nine out of 14 (64\%) working women had a job previous to receiving the Bolsa Família transfers and five (36\%) got a job after getting the transfers. 10 of the non-working beneficiaries in Brazil stated that they would like to get a job. Their main reason for wanting to work was to gain independence from their husband or partner. As beneficiary B12 (32, 6 children) from Quixadá shared: "If I could work now, I'd leave my husband. I live with him so he supports me and my children. My husband doesn't know I get Bolsa Família. I don't tell him because he uses drugs, I hide it. Everything that he earns, he spends it."

These beneficiary women live in extreme poverty. Due to their lack of resources and lack of access to opportunities, such as well-paid jobs, and infrastructure, such as drinking water and paved streets, they endure very hard lives. From our time in the communities, we could see how daily life is mostly lived day by day, without the possibility of saving for the future or having the luxury of some leisure time. Most of these women, however, are motivated to work by the desire of giving a better life to their children. They comply with the CCTs' conditionalities because 
they want to give their children better health, education, and future productive opportunities.

\subsubsection{Barriers to Work}

This research also shows that the main reasons for not working for both beneficiaries and non-beneficiaries, in both countries, are the lack of child care, lack of education and human capital, and old age. Many beneficiaries state that they would like to work, but they feel it is not possible for them to do so.

Regarding taking care of children as an impediment for working, beneficiary M10 from Campeche City (40, 4 children) explained: "I worked before getting married and my husband liked that, but I stopped when I had children in order to take care of them." In Brazil, child-bearing also seems to be the main reason for women to stop working as these beneficiaries from Fortaleza and Quixadá shared: "When I am not pregnant or with small babies, I work informally." (B10, 27, 3 children), "I always wanted to work, but my parents told me not to, and then I got married and had children, and I needed to take care of them. But this year I want to work," (B4, 29, 1 child), and "Of course I want to work, I'm just waiting for them [my children] to be older." (B12, 32, 6 children).

Regarding the lack of education as a reason for not being able to work, these beneficiaries from Tenabo shared their experiences: "I would like to work but I don't have education; I couldn't look for a job," (M24, 37, 3 children) and "I want to work because we don't have enough money, I'm looking hard for a job, but it is hard to find one because I can't read." (M30, 40, 3 children).

Old age is also a problem when women feel they need an extra income, but they are physically weak or nobody hires them anymore. As M9 (53, 5 children) from Campeche city explained: "I have thought about getting a job, but I'm too old to get something. Since I got married I stopped working to take care of my children and now it's too late."

\subsubsection{The Employment Trigger-Effect of CCTs}

It is also noteworthy that in both Mexico and in Brazil, a percentage of beneficiary women participating in the labour market did not used to work before receiving the transfers and only started to work after having that extra income (see Figure 4.3). In Mexico, four out of 20 working beneficiaries started to work after getting the transfers, and in Brazil five out of 14 working beneficiaries started to participate in the labour market after receiving Bolsa Família. These results would support Tavares (2010), who found evidence that mothers receiving Bolsa Família 
showed a $5.6 \%$ higher probability of participating in the labour market after receiving the benefits.

For these beneficiaries, receiving the transfers started a process of wanting to improve their economic and personal situations. Beneficiary M14 from Hecelchakán (36, 4 children) explained why: "I realised that my husband earned very little money and I wanted to help as well, for us to have a better nutrition, a better life quality." This thought seems to be quite common, and it was heard in other places as well, for example in Tenabo, where beneficiary M24 (37, 3 children) stated: "After starting to receive the transfers, I decided to work to get an extra income."

Nonetheless, while the above-mentioned women started to work after receiving the transfers, there is also evidence of other women whom stopped working as a consequence of receiving the transfers. In Mexico, no beneficiary said they stopped working after receiving the transfers because of having more income. However, in Brazil, three women said that they stopped working since now they had more resources. These answers are consistent with the findings of Pedrozo (2010), who found that the Bolsa Família programme led to a negative effect on adults' labour supply.

Regarding criticism against CCTs stating that they provide incentives not to work, in the field research it was found three women in Brazil who openly said they had stopped participating in the labour market as a result of receiving the Bolsa Família transfers and therefore counting with some extra income. However, these women said they stopped working in order to take care of their children, and not because of the so-called "laziness effect." 44 From these women, one was from the capital of the state, Fortaleza, and the other two were from the semi-urban community of Quixadá. The beneficiary B6 (35, 2 children) from Conjunto Ceará in Fortaleza explained why she decided to stop working:

"Since we receive Bolsa (Família) my husband wants me to work less because now there is a new source of income. And I also thought of working less to give more care to my children. Before, I worked a lot, I did not have time to be with my children. Because of getting the money I can take better care of my children. My position in the family is better now. Everything improved, it helped everything."

Beneficiary B18 from Quixadá (38, mother of five) said:

\footnotetext{
44 The "laziness effect" refers to the CCT's stimulation of a reduction in labour supply of adults. For more on this topic, see Chitolina et al. (2016).
} 
"I stopped working when I had my children to take care of them. Now I would like to work when my baby is older, but my husband does not want me to work. With Bolsa Familia I know every month I get money so that I can buy things for my children. It is a very good help to buy school supplies, shoes [...] also I know that I can stay home and care for my children because I have that income."

However, beneficiary B16 from Quixadá (44, 2 children) explained a different reason, health-related, why she stopped working: "I started to suffer from panic and depression, it was horrible. Now because of the government, I can take my medicines and get government money (Bolsa Família). I am happy I do not need to work anymore and have money."

This shows that there is indeed ambiguity in the labour market participation results and that numbers and percentages of wider studies need to be taken with a grain of salt, since normally the decision to stop working is not a straight-forward consequence of increased income, but may have to do with other personal factors, such as health problems, old age and young children. This decision could also be regarded as a perceived increase in well-being, which is a positive outcome, since now women can support themselves and their children with the help of the transfers.

When analysing all the results, it could be concluded that the overall effect of the CCTs on women's labour participation is still positive and that there was an "employment trigger-effect" of the CCTs. In Mexico four women started to work after getting the transfers and none stopped working as a consequence of them. And in Brazil, even if three women stopped working because of the extra income, five other beneficiaries started to work after receiving the transfers.

The small trigger-effect of the transfers on the participation of beneficiaries in the labour market could be explained by the fact that the amount of the transfers is very small so the beneficiaries cannot stop working, even if they would want to. These results seem to be in line with a study by Ferro and Nicolella (2007) who found that participation in a CCT programme did not affect the probability of parents participating in the labour force. As beneficiary M1 (51, 3 children) from Campeche explained, now that she receives the transfers, she continues to work as before, since: "One cannot live from the transfers, it's too little, I would starve."

The results in Mexico are also consistent with the results of Brazil, where many working women, now beneficiaries, continue to consider their work very important. As beneficiary B1 (39, 5 children) from Fortaleza said: "I work, I have always worked. I have always been in charge of my situation. I don't want anyone to 
command me what to do. I think people should always work, whether they receive Bolsa Família transfers or not. Bolsa Família is just a complement."

The interviewees' testimonies show us clearly that gender plays an important role for women's labour market participation. Since these women are mothers, they need to take care of their children. This dilemma is faced everyday by women all around the world. Women from better-off backgrounds might have access to a better social network that could help them take care of their children (parents, inlaws, etc) or have the resources to pay for childcare activities (such as nannies, or day-care). However, the women we interviewed do not have many alternatives. In a context where the men will not stop working to take care of the children or household chores (because of gender norms and because they normally are the higher earners in the family), women are left with the responsibility even if it is to the detriment of the household final income.

\subsection{Conclusion}

It was mentioned earlier that neoclassical economic theory suggests some ways in which CCTs can affect labour participation decisions within beneficiary households (Browning et al., 2006; Chiappori and Donni, 2009). These potential effects can be explained based on the standard static model of labour supply, where individuals maximise between consumption and leisure.

In general, the results of this study indicated that both programmes have not had any major impact on the labour market participation of the interviewees and have not introduced any substantial disincentives to work. These results are consistent with those of Alzúa et al. (2013). The finding that monetary transfers have not had an impact on employment is compatible with a setting in which income effects are either small or counterbalanced by some other factors-assuming that leisure is a normal good for beneficiaries. The field research showed changes in labour participation of a few of the beneficiaries. Some beneficiaries stopped working after receiving the transfers, which is consistent with the standard model of labour supply: cash transfers represent an increase in (non-labour) income. In this case, the transfer is a pure income effect and therefore, both employment and working hours should be expected to decline. However, contrary to this model, other women started to work after receiving the transfers, causing what we called an employment trigger-effect of the CCTs. These beneficiaries explained that after receiving the transfers, they realised they were having a very small income and wanted to have more money, having found more time to work. This result could be explained with the second channel through which adult labour supply could be impacted pointed out by Alzúa et al. (2013), which states that since cash transfer programmes imply school enrollment conditionalities, this increase in children's 
school attendance could allow parents to increase labour participation, by providing them with more time where they do not need to focus on the children.

In most cases, the impact of CCTs on adult labour supply is small, even when heterogeneity due to the distribution of power in the household is considered. This strongly suggests that there are little adult labour supply changes due to the CCTs. Fiszbein et al. (2009) offer some explanations for the absence of larger effects of CCTs on adults' labour supply. It might be that the income elasticity of leisure is very low among poor households. It is also likely that accomplishing the CCT conditionalities implies increasing costs in an amount similar or higher than the transfer itself. In addition, it might be that the transfer is perceived by households as temporary, rather than permanent. Finally, it could be that potential labour supply effects are being studied too soon after the implementation of the programmes, and therefore, potential long-run effects are not being captured.

However, there are complex and nuanced patterns of response emerging from both Oportunidades and Bolsa Família beneficiaries. This research suggests that most women see work as a source of pride which influences their self-esteem in a positive manner. Furthermore, they have important motivations to work, such as making their own money to achieve independence from their partners, to be able to buy and save more, and to give their children a better life. In the area of labour market access barriers, the research suggests that most women who do not work or stopped working did so because of three main barriers: lack of child care, lack of education, and old age.

This situation shows that public policies need to be developed which help women have better opportunities, such as flexible work hours, more part-time employment, family money, and maternity leave. In developed countries, maternity leave policies are in place so women can take time off their work, and continue to be paid for some months while they give birth and for the first months of the babies. However, in most of the developing countries, maternity leaves are not in place, or they are offered only to women in the formal sector. This situation pushes women to make a decision between their children or work, which is detrimental to their own economies and of the national economies in general, especially since women make up $50 \%$ of the population. This study's results should be taken into account to create more inclusive and integral public policies, and in the design of welfare programmes. Policies such as universal access to education, maternity leave, child care and old age pensions should be in place for the population. Developing countries such as Mexico and Brazil are already taking steps towards this direction; however, still a large percentage of the vulnerable population experiences a lack of access to basic protection, and policies could be improved to further strengthen the potential positive effects of CCTs. 


\section{Chapter 5. CCTs and Women's Intra-Household Decision-Making}

\subsection{Introduction}

Women's empowerment, understood as women's ability to participate on the basis of equality in all spheres of decision-making, both public and private, has both intrinsic and instrumental value: intrinsic in that greater equality in decisionmaking is desirable in its own right (UN, 1995); instrumental in that more decisionmaking power for women has been linked to a range of desirable outcomes, particularly those related to child welfare (Hoddinott and Haddad, 1995). Empowerment can be enhanced not only through legal changes and changes to social norms, but also through economic factors. The potential for economic factors -and in particular, women's control of resources- to affect women's control over decision-making has both theoretical and empirical support in the literature (Handa et al., 2009; Doss, 2013). In Nash's (1950) cooperative bargaining models of household behaviour, an increase in the amount of resources controlled by the woman increases her "outside option" of exiting a partnership and therefore her bargaining power within the partnership, giving her more of a voice in decisions. There is evidence that resource control, in turn, can be enhanced by giving women more rights to productive assets or through transfers of resources to women which are independent of marriage (Malhotra and Mather, 1997; Handa et al., 2009).

A feature of many conditional cash transfer programmes (CCTs), widespread in Latin America and increasingly popular throughout the world, is that cash transfers are given to women. This feature was itself informed by earlier research suggesting that increased resource control by women was linked to both increased decision-making power for women and improved outcomes for children (see, for example, Behrman, 2010). The Oportunidades programme in Mexico and the Bolsa Família programme in Brazil are examples of such CCTs, wherein designating women as transfer recipients "[...] is intended to compensate mothers for their traditional domestic and care work role, to ensure that programme coresponsibilities are met and in recognition of the fact that they are most likely to ensure that increased household income benefits children. Transferring cash to women is also seen as a way to promote their control over household resources and increase their bargaining power at home" (Holmes and Jones, 2010: 15).

However, transferring cash to women does not necessarily imply that women's control over household resources increases. Given the growing popularity of such programmes and widespread interest in increasing women's empowerment, it is 
important to assess whether resource transfers to women through these programmes are in fact effective in improving women's positions within the household. While some qualitative studies suggest that CCTs targeting female beneficiaries increase women's decision-making power on certain issues within the household (Adato et al., 2000; Handa et al., 2009; Adato and Roopnaraine, 2010), evidence of this effect in the context of CCTs is both limited and mixed. ${ }^{45}$ This chapter contributes to providing more knowledge on this topic by presenting qualitative evidence on the effect of the Oportunidades/Prospera programme in Mexico and the Bolsa Família programme in Brazil on women's intra-household decision making.

The objective of this chapter is to cast light on the effect that CCTs are having on women's intra-household decision-making in Mexico and Brazil. The findings suggest that decision-making happens in gender-specific ways. There is a small effect especially on the areas of food expenditure and decisions related to children. However, there is not much effect on traditional (patriarchal) gender norms regarding intra-household decision-making, i.e. there is a persistence of traditional gender norms despite CCT receipt. Such persistence is mostly related to women's lack of education (human capital/social class) and dependent on their location/type of community (urban vs. rural).

The chapter is structured as follows: the second section reviews the theories of decision-making and the current findings on the effect of Oportunidades/Prospera and Bolsa Família on the decision-making power of beneficiaries. The third section presents the research methods. The fourth section presents the findings, and the final section provides concluding remarks.

\subsection{Literature Review}

\subsubsection{Models of Intra-Household Decision-Making}

As it was mentioned in the previous chapter, there are two main models that explain household behavior. The first one is the unitary model and the second one is the collective or bargaining model. The unitary model assumes that family members act as if they were maximizing a single utility function. This assumption ignores the potential for unequal power and unequal resource distribution within households. In 1981 Becker developed a household model which became the

\footnotetext{
45 Critics such as Mayoux (2006) have argued that the incorporation of gender issues into materialfocused poverty reduction measures risks "evaporation" into merely using women's time and resources for programme efficiency or community development, without improving their decision-making power or position in the household.
} 
standard model of distribution within households. In this model, an "altruistic" head of the household -the husband, father, or patriarch- aggregates the preferences of each individual in the household to form one joint utility function and maximizes that utility.

In contrast, the collective or bargaining model interprets the intra-household allocation of resources as an outcome of bargaining processes among the members of a household. This model recognises individual members of a household as separate agents with their own preferences and utility functions. Different bargaining models differ in their assumptions regarding the sources of a person's bargaining power, but they all typically emphasise access to economic resources, such as earnings or wealth, as a critical source of a person's bargaining power (Iversen, 2003). Following this assumption, CCT programmes, such as Oportunidades and Bolsa Família, have the potential of creating a change in the intra-household power distribution and decision-making process, by providing the beneficiaries with more economic resources.

\subsubsection{A Gendered Perspective on Intra-Household Decision-Making}

From a gender perspective, it can be argued that these models do not take into consideration social norms and gender roles, so they can be restrictive to reflect the true working of actual households. Social norms may strengthen or weaken women's intra-household bargaining position by affecting their bargaining power. Existing social norms can negatively affect women's bargaining power by restricting women's earning possibilities, by preventing them from working outside the home, by defining care for their family members as their responsibility, and by limiting the range of tasks they can perform (Agarwal, 1997).

An analysis of decision-making power within a household is necessary in order to understand the complexities that take place during the bargaining process within the household. Such analysis can contribute to explain how changing norms and added income can affect resource allocations. It can also help explain how this change in resource allocation and the strategic interactions that determine it can reinforce and challenge prevailing social norms, especially those regarding gender relations. Social and cultural norms often define how household members should conduct themselves, mediated by gender, social class, age, marital status, and other social categories. The cultural construction of gendered behaviour affects the decision-making power within the household (Mader and Schneebaum, 2013).

Gendered inequalities in decision-making can be explained by Wolley and Marshall's (1994) idea of "orchestration power." They explain that when one partner has the power to make only the "important" and infrequent decisions 
which determine major characteristics of their household, while relegating "unimportant" and time-consuming decisions to their spouse, the former is said to have "orchestration power." While women have some decision-making power and responsibility, one might see some degree of inequality in the nature, prestige, and valuation of women's decisions. This is in line with the findings of this research, which suggest gendered areas of decision making, with women making small daily decisions (i.e. grocery shopping, what to cook, etc.) and men making bigger and more important decisions (i.e. where to live, whether to renovate the house, etc.).

As the models discussed above have shown, a person's bargaining power can be measured by a person's resources, such as their labour and non-labour income, transfer payments, labour supply, and assets. Educational attainment is also considered a resource that contributes to bargaining power, which is intrinsically linked to their human capital. Osmani (2007) observed bargaining power for female loan-takers in Bangladesh by the following indicators: assets owned, age, educational level, and number of children. Another very extensive body of scholarship on possible indicators to observe and measure women's bargaining power in developing countries discussed the role of income and employment (earned income, non-earned income, employment status, migration status), asset ownership (assets owned, assets brought to marriage), and human capital (education) in decision-making power and attitudes (decision-making over expenditure, over selling assets, autonomy, and knowledge-especially of laws and opportunities, attitudes about women's role and perception of social norms) (Doss, 2013).

Studies that analyse intra-household behaviour propose that the bargaining power of spouses is crucial in determining who gets a larger share of household resources. While it may be difficult to measure power within the household, bargaining power may be affected by four sets of determinants (Adato et al., 2000):

1) control over resources, such as assets;

2) influences that can be used to alter the bargaining process (i.e. legal rights, skills and knowledge, the capacity to acquire information, education, and bargaining skills);

3) mobilisation of interpersonal networks; and

4) essential attitudinal attributes (i.e. self-esteem, self-confidence, and emotional satisfaction).

Economic analyses of bargaining power have tended to focus on economic resources exogenous to labour supply as a major determinant of bargaining power. These include assets (Doss, 2013), unearned income (Thomas, 1990), or transfer payments and welfare receipt (Lundberg and Pollak, 1996). The threat of 
withdrawing both oneself and one's assets from the household grants the owner of those assets some power over household resources. These threats are credible if supported by community norms or divorce laws (Quisumbing and De la Brière, 2000).

Factors which can influence the bargaining process include legal rights, skills and knowledge, the capacity to acquire information, education, and bargaining skills. Some of these influences are external to the individual (i.e. legal rights), but many of them are highly correlated with human capital or education. In some instances, domestic violence can be used to extract resources from spouses or their families, as in the case of dowry-related violence in India (Rao, 1997). Individuals can also mobilise personal networks to improve their bargaining power. This social capital, such as membership in organisations, access to kin and other social networks may positively influence a person's power to affect household decisions. Many of these social networks are related to one's family's status within a community. Lastly, attitudinal attributes that affect bargaining power include self-esteem, selfconfidence, and emotional satisfaction (Quisumbing, 2010).

While economic analyses of intra-household issues have typically focused on the aspect of control over resources, Oportunidades and Bolsa Família have the potential to address all four factors affecting bargaining power, and to influence processes of women's empowerment in the following ways:

1) by increasing resources in the hands of women;

2) by helping women learn through health education;

3) by creating a network of co-beneficiaries with whom women meet on a regular basis (improving their social capital);

4) by increasing confidence and self-esteem through participation in the meetings and having control of additional resources;

5) by requiring visits to health facilities; and

6) through promoting the education of girls, improving the position of future women.

\subsubsection{Previous Findings in Mexico and Brazil on the Impact of CCTs on Intra- Household Decision-Making}

The literature addressing the effect of CCT programmes on different variables of interest is vast and continuously growing. This section presents evidence of previous research on the effects of CCTs on beneficiaries, particularly on intrahousehold decision-making. 


\subsubsection{Oportunidades/Prospera}

Oportunidades objectives state that one of the main aims of the programme is "strengthening the capabilities of beneficiary family members" (Oportunidades, 2006: 8). Through the adoption of a gender perspective the programme seeks "to promote the equal access of women to its benefits," (Oportunidades, 2006: 8) recognising that "poverty acquires different forms according to the inequalities that prevail between the sexes" (Oportunidades, 2006: 8). One of the claims of the programme is to help empower the mothers and daughters of beneficiary families. Transfers made directly to the mothers are widely accepted to benefit their households through more equitable distribution, but by giving women direct control over cash resources, their standing in their communities as well as their leverage within the household can be enhanced.

In a study conducted by Adato et al. (2000) on the impact of Oportunidades on women's status and intra-household relations, a questionnaire was created including questions on eight decision-making areas: 1) medical treatment for child, 2) school attendance, 3) clothing for children, 4) food expenditures, 5) major house repairs, 6) decision to spend women's extra income, 7) decisions related to children, and 8) durable purchases. The respondents needed to choose among the following answers: 1) husband decides alone, 2) wife decides alone, and 3) husband and wife decide jointly. They found that the demographic characteristics of husband and wife are the most consistent determinants of decision-making patterns. Their research suggests that the husband is more likely to be the sole decision-maker if his wife is less educated, has less work experience prior to marriage, does not speak Spanish, or speaks an indigenous language. Husbands who speak an indigenous language are also more likely to be the single decisionmaker, indicating that women's roles may be more traditional in indigenous societies. Research also reveals that, after receiving the transfers, husbands are less likely to make decisions by themselves for five out of eight decision-making areas: medical attention for child, school attendance, children's clothing, food expenditures, and house repairs. Particularly noteworthy is the fact that there was an increase in the probability that women decide on the use of their extra income by themselves, and a decline in the probability that they let their husbands decide (Adato et al., 2000).

Adato et al. (2000) argue that there are four ways in which respondents suggest that Oportunidades can increase women's autonomy with respect to household expenditure decisions:

1) Independence in financial decisions using Oportunidades' transfers;

2) Increase in decision-making confidence;

3) Increase in number of food-related decisions; and 
4) Increase in decisions on clothing for children and personal expenditure.

Gómez de León and Parker (1999) conducted a similar analysis using three different groups of indicators: 1) those corresponding to who makes household decisions related to children, 2) who makes decisions regarding expenditures, and 3) the degree of freedom women have to move about freely. They made an effort to rank the outcomes of the effect of Oportunidades on decision-making in terms of women's empowering as follows: a woman is most empowered when she makes decisions alone, followed by joint decisions, and least empowered when her husband makes decisions alone. Their research found that there was an apparent "jointness" of decision-making. The dominant response was that decisions were taken jointly by husband and wife. Aside from joint decisions, decisions regarding large household expenditures (i.e. house repairs, durable purchases) were more likely to be made by the husband alone, while decisions on food expenses and on children (taking the child for medical attention, telling the child to go to school) were more equally likely to be made by either spouse. Regarding mobility, they found that women's mobility seemed to be rather limited. In the vast majority of cases, a woman would seek her husband's permission before visiting friends or relatives. However, the interpretation of mobility is ambiguous. Going to visit a friend or relative alone does not necessarily mean that the woman is more empowered than a woman who is accompanied by their children, especially since Adato and Roopnaraine (2010) have indicated that in their focus groups in communities, they found out that women like to take their children as they go visiting.

Quisumbing and De la Brière (2000) analysed the impact of Oportunidades on intra-household decision-making and identified certain variables that appeared to be significant determinants of decision-making within the marriage. They found that wife's education and work experience prior to marriage were positively associated with her making decisions solely, and negatively associated with her husband's deciding by himself. Being able to speak Spanish also gave women an additional advantage. In contrast, speaking an indigenous language, and having a husband who also spoke an indigenous language, made women less likely to make decisions by themselves. Based on their findings, Quisumbing and De la Brière (2000) also argue that among poor households, Oportunidades by itself has had a significant effect on decision-making patterns. They mention that an interesting finding is that transfers seem to reduce sole decision-making by husbands with regard to medical treatment, school attendance and children's clothing. They also point out that the transfers have an effect on reducing the probability of women letting their husbands decide how to spend their additional income. They conclude that this confirms the belief that transfers targeted to poor women have the potential to change decision-making patterns within households. 
Adato and Roopnaraine's (2010) research pointed out that, with respect to control of decisions on household expenditures, women generally claimed that the man was the ultimate authority in the family. This means that if the man objected to something, the woman could not do it. However, they also found a consensus that women made most decisions about small household expenditures, particularly food purchases. Most women commented that they made the food purchases since the mothers know best what they needed. However, they found little difference in the comments of beneficiaries and non-beneficiaries, suggesting that this hierarchy of intra-household decision-making preceded Oportunidades.

Handa et al. (2009) studied the effect of gender targeting and conditionality on household spending behaviour. The researchers pointed out that gender targeting of Oportunidades has not appreciably increased the overall decision-making power of women, although women are reported to have more control over cash income as a result of the programme. Furthermore, they suggested that this additional control over cash income does not significantly change spending behaviour. They explained that this may be because husbands and wives have common preferences or because transfer income crowds out intra-household transfers from husbands to wives and so have no net impact on the composition of spending. Some authors such as Molyneux (2007a) pointed out that more research is needed regarding the gender impact of these programmes in order to establish if they are producing a redistribution of power and status within households and, if so, to explain what effects this status change has on household livelihoods and well-being. Therefore, this study aims at providing more in-depth knowledge in this area and to shed more light on the effect of conditional cash transfers on women's empowerment, particularly in the area of intra-household decisionmaking.

Other critics of conditional cash transfer programmes have argued that in some contexts, transfers paid directly to women have the potential to generate conflict if men feel they are entitled to control money resources and resent any undermining of their authority. However, a small-scale study of men's attitudes carried out by Maldonado et al. (2006) in three rural communities in Mexico (10 interviews in each community) found no strong evidence linking women's receipt of transfers to a rise in the incidence of domestic violence. The transfers were apparently viewed by men as expressly intended for the benefit of the children, "not as money belonging to their mothers." Their report stated that since men perceived the women as merely administering the funds for the education and well-being of their children, this was not seen as a cause of conflict. Despite these findings, expert opinion is divided over the reliability and generalizability of the data collected on this sensitive issue. Whether violence against women has risen or not as a result of these programmes, particularly in indigenous communities, it 
remains a serious problem that has not been sufficiently addressed by community leaders and government authorities (Molyneux, 2007b).

Overall, Oportunidades has sought to respond to some of the gaps in its provision and has taken into account its regular evaluations in the modifications of its programme. It has shown itself responsive to gender advocacy and has gone some way to incorporating gender equity principles, but its construction of needs reveal that different logics operate in relation to daughters and mothers-the former are invested in as citizens, and their capabilities and life chances are expanded through education and health; the mothers, meanwhile, are treated as having responsibilities rather than needs and rights. Molyneux (2007b) states that Oportunidades therefore remains in essence a maternalist programme in that it aims to fortify the responsibilities of motherhood as a way to improving the life chances of children. Its human development rationale accurately describes the programme's intent as far as children are concerned, but the programme's combined focus on mothering and reproductive health has made it less likely to develop a more differentiated set of capacities for the mothers who are responsible for ensuring that programme goals are met. Moreover, in failing to grapple with the realities of poor women's lives, it risks adding to their burden of responsibility rather than improving their decision-making power and empowerment.

\subsubsection{Bolsa Família}

Numerous evaluations on the impact of Bolsa Família have been undertaken. Among these, research conducted on the impact of Bolsa Família on women's decision-making power by De Brauw et al. (2014) has focused on a set of questions that directly addresses the process of decision-making. Such questions addressed who in the household generally makes decisions about a range of issues: 1) purchases of food, 2) clothing for yourself, 3) clothing for your spouse or partner, 4) clothing for children, 5) when your child must stop attending school, 6) healthrelated expenditures for children, 7) the purchase of consumer durables for the home, 8) if you work or not, 9) if your spouse works, and 10) your decision to use contraception. Response options included "myself," "my spouse or partner," "decisions are made jointly," "decisions are made by others," "decisions are made by children," and "I don't know."

De Brauw et al. (2014) pointed out that in 2009 there were substantial differences between the answers of Bolsa Família beneficiaries and non-beneficiaries. They also suggested that cash transfers created increases in intra-household decisionmaking power along several dimensions. An important finding is that participation in Bolsa Família increased the share of women who reported exclusive control over contraception decisions by ten percentage points in an 
aggregated estimation sample. When disaggregating between urban and rural areas, they found that in urban areas, not only were the impacts on decisionmaking regarding contraception even larger and more strongly significant, but there were also significant increases in women's control over decisions in several other areas including children's school attendance, children's health expenses, purchases of durable goods, and expenditures on women's clothes. They also observed that such disaggregation revealed that all statistically significant positive impacts in their sample were concentrated in urban areas. In rural areas, they found indications that Bolsa Família may have slightly negative impacts on women's decision-making power.

They argued that since the conditionalities for Bolsa Família included health visits both for children and for pregnant women, it was possible that the results on contraception came partly from women having increased exposure to information on contraception. If women have different preferences for contraception than men, and if women are allowed to control the resources they receive, they may also have more bargaining power and greater means to purchase their preferred contraceptive methods. De Brauw et al. (2014) also found that in urban areas, the impacts on contraception were even larger (16-18\%) than in rural areas; and that there were also significant increases in many other areas, including children's school attendance (11-14\%), children's health expenses (13-15\%), durable goods (8$14 \%)$, and own clothes (9\%).

Finally, they concluded that all significant positive impacts in their sample were concentrated in urban areas. Meanwhile, in rural areas, there were indicators that Bolsa Família may have slightly negative impacts on women's decision-making power, including a weakly significant decrease in women's decision-making regarding contraception (a decrease of 11\%). These results suggested the possibility that cash transfers to women may translate very differently to women's resource control in the two types of areas, possibly even indicating that in rural areas men may seize the transfers, leading women to have less bargaining power. These results offered a first direct quantitative evidence of CCTs' impact on specific areas of women's decision-making. Furthermore, they showed that effects occur both in the spheres related to child-rearing and in spheres related to women's own welfare and protection of the household, suggesting that the impacts may be interpreted as greater equity in the household rather than greater burdening of women with gender-stereotyped roles as argued by Molyneux (2007b). As such, these results indicate that conditional cash transfers distributed to women in the household may be an effective way to give women more voice in household decisions. 


\subsection{Methods}

The objective of this study is to contribute to the current knowledge of the effect of conditional cash transfer programmes on intra-household decision-making. By making women the programme beneficiaries on behalf of the family, Oportunidades and Bolsa Família aim to empower them by increasing their control over resources. One could argue that by having the female head of the households receive the transfers, the recipient women would have a sense of economic empowerment-by administrating the resources. Furthermore, it could be said that this empowerment would have a trickle-down effect in the decision-making process within the household (Lundberg and Pollak, 1996; Adato et al., 2000; Quisumbing, 2010; Doss, 2013). Based on this assumption we went to Campeche, in the Southeast of Mexico, and to Ceará, in the Northeast of Brazil, to conduct indepth interviews with women beneficiaries and non-beneficiaries in order to find some clarity about the consequences that beneficiaries of Oportunidades and Bolsa Família, respectively, experience in intra-household decision-making processes. Now that women are receiving some fixed money monthly, do they feel like their voices have more power in the household? Are they able to administrate these resources and use them for improving their lifestyle and their children's-by accessing better nutrition, better quality articles, saving? Do they have control over child-bearing decisions? Do they feel like their opinion is more valued and respected and why? Do they feel their opinions have the same weight as their husbands' and why?

The research method used to assess these questions was based on case study field work. Data for this study come from the qualitative analysis of semi-structured indepth interviews with 120 beneficiaries and non-beneficiaries of the Oportunidades and Bolsa Família programmes, conducted face-to-face in 2012. In order to focus and streamline the data gathering process, the study benefited from pre-structured qualitative data collection and analysis. The research questions were well specified prior to the field work. The modelling of the case studies, the poverty mapping to choose the interviewees, and the elaboration of the interview guide with a defined set of specific questions were undertaken before any data were collected. ${ }^{46}$ The analysis in this chapter focuses on the findings regarding the intra-household decision-making process for both beneficiaries and nonbeneficiaries. The questions in the interviews are distributed in five areas of decision-making and assess whether women can make the household decisions and their views on decision-making related to: 1) expenditure, 2) children's issues, 3) personal decisions, 4) reproductive decisions, and 5) mobility.

\footnotetext{
${ }^{46}$ See Annexes 1, 2, and 3 for interview guides.
} 
In order to find out the gendered intra-household decision-making processes, open questions were asked regarding: 1) who makes most decisions in the household and why, 2) which decisions are made by the wife and why, and 3) which decisions are made by the husband, and why. Interviewees were asked to elaborate when necessary.

\subsection{Findings}

As it has been explained in the methods section, this research focused on five main areas of decision-making. Box 5.1 provides a summary of the decision-making dimensions analysed in this chapter, together with their indicators and ways of measurements. This classification attempted to clarify the complex web of intrahousehold decision-making processes and to provide a more holistic understanding by analysing them using the economic, familial, personal, reproductive and socio-cultural dimensions.

\section{Box 5.1 Dimensions of decision-making, indicators and measurement}

\begin{tabular}{|c|c|c|}
\hline $\begin{array}{l}\text { Dimensions of } \\
\text { decision-making }\end{array}$ & Indicators & Measured by \\
\hline Economic & $\begin{array}{l}\text { Domestic decision- } \\
\text { making and control } \\
\text { over resources }\end{array}$ & $\begin{array}{l}\text { Household expenditures on: } \\
\text {-Children } \\
\text {-Food } \\
\text {-Durable purchases } \\
\text {-Personal items } \\
\text {-Savings }\end{array}$ \\
\hline Familial & Children's issues & $\begin{array}{l}\text {-School attendance } \\
\text {-Attendance at health care check-ups } \\
\text {-Purchase of clothing and school items } \\
\text {-Purchase of medicines }\end{array}$ \\
\hline Personal & Personal decisions & $\begin{array}{l}\text {-Ability to choose occupation } \\
\text {-Ability to participate in activities } \\
\text {-Ability to choose friendships }\end{array}$ \\
\hline Reproductive & $\begin{array}{l}\text { Control over own } \\
\text { body }\end{array}$ & $\begin{array}{l}\text {-Use of contraception } \\
\text {-Control over sexual relations } \\
\text {-Control over child-bearing } \\
\text {-Attendance at health check-ups }\end{array}$ \\
\hline Socio-cultural & $\begin{array}{l}\text { Freedom of } \\
\text { mobility }\end{array}$ & $\begin{array}{l}\text {-Ability to leave house alone } \\
\text {-Ability to leave house accompanied } \\
\text {-Ability to meet female relatives and friends } \\
\text {-Ability to meet male relatives and friends }\end{array}$ \\
\hline
\end{tabular}

Source: Own author's research 


\subsubsection{Economic Decisions}

In the area of household expenditures, questions were asked in the following areas: 1) expenditure on children, 2) food expenditure, 3) durable purchases, 4) personal items, and 5) money saved. Figure 5.1 shows that in the area of economic decisionmaking, women could mostly decide how to spend the money in the following order: 1) food expenditure, 2) personal expenditure, 3) expenditure on children, 4) durable goods, and 5) savings. ${ }^{47}$

In the food expenditure area, 28 out of 30 (93\%) beneficiaries from Oportunidades and 29 out of 30 (97\%) non-beneficiaries could spend the money without asking their husbands. The difference among beneficiaries and non-beneficiaries was very small, suggesting that receiving the transfers did not create a big effect on food expenditure in this sample and that women have been traditionally the ones who have made the decisions regarding food expenditure.

Figure 5.1 Interviewees' self-reported decision-making power in the area of household expenditure

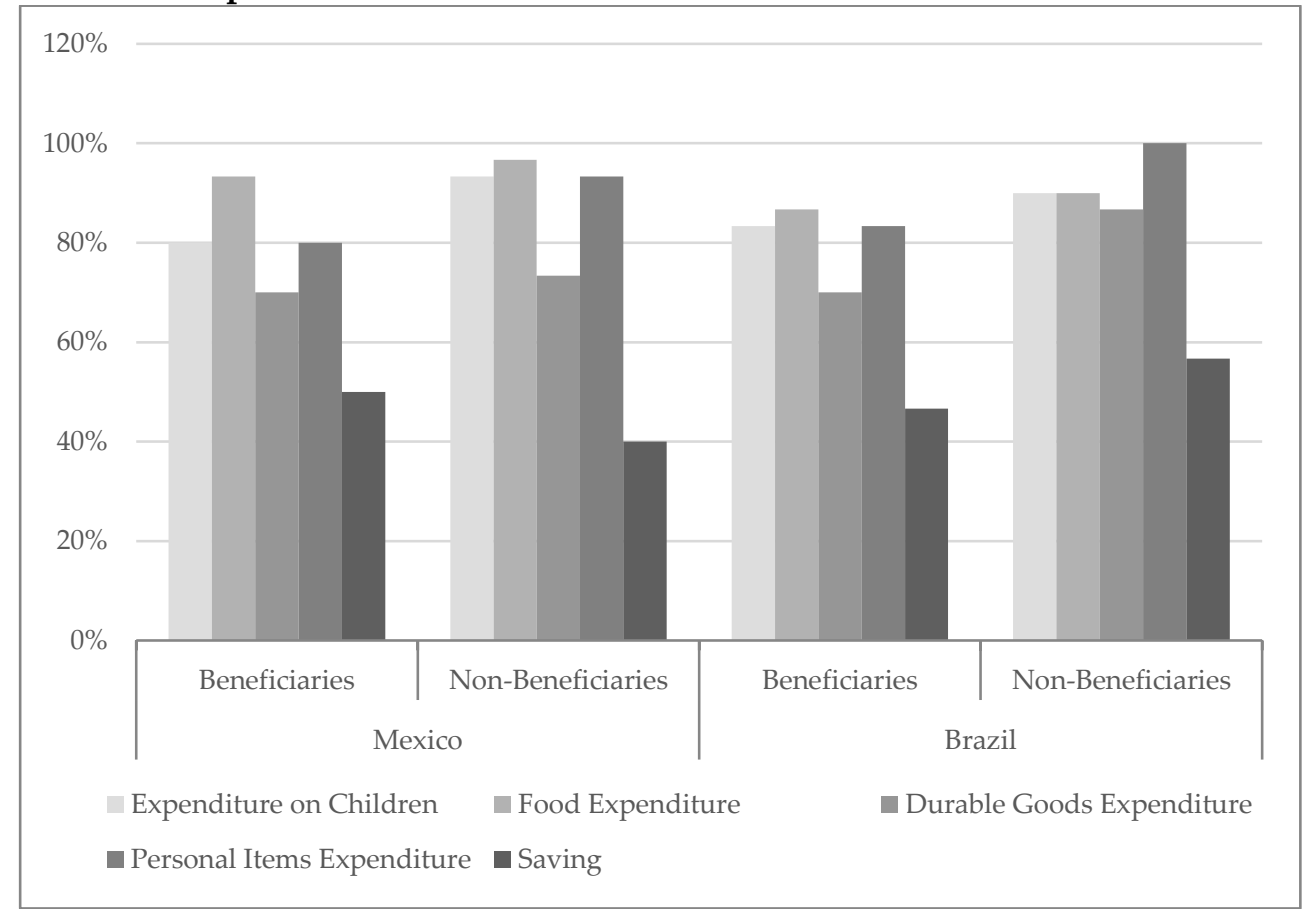

Source: Author's own data

47 These results are condensed from Table A5.1 which can be viewed in detail in Annex 6. 
In the case of Brazil, 26 out of 30 (87\%) beneficiaries from Bolsa Família and 27 out of $30(90 \%)$ non-beneficiaries also could make food purchasing decisions. These findings were in line with Adato and Roopnaraine's (2010) research, which pointed out that women make most decisions about small household expenditures, particularly food purchases. They also found little difference in the comments of beneficiaries and non-beneficiaries, suggesting that this hierarchy of intrahousehold decision-making preceded participation in the CCTs. Handa et al. (2009) also suggested that the transfers do not significantly change spending behaviour.

During field research, when asked about whether or not interviewees could spend money on food without asking for their husband's permission, the most common answer among both beneficiaries and non-beneficiaries was that "Of course I can! And I do!" In most cases, the husband was the only bread-winner and he gave the money to the woman to administrate. She was then in charge of allocating the resources to their needs, as non-beneficiary M38 (36, two children) in Campeche suggested: "My husband doesn't question my money expenditure and management (regarding food and children's issues)." However, in the case of the older generation, the situation seemed to be different, as 52-year-old Oportunidades beneficiary M8 (widow, 3 children) from Campeche commented: "I am a widow now, but when my husband was alive, I could spend money on personal items but it created fights, even if the money was not his, he'd get upset."

In the area of personal expenditure, the findings suggested that 24 out of $30(80 \%)$ beneficiaries of Oportunidades could decide to spend some money on personal items, compared to 28 out of 30 (93\%) non-beneficiaries. In Brazil, the same trend was observed: 25 out of $30(83 \%)$ beneficiaries of Bolsa Família could decide to spend money on personal items, compared to all non-beneficiaries. These results could suggest that non-beneficiaries in both countries have a higher decisionmaking power in this area than beneficiaries. This could be explained due to the lack of economic resources and lack of education of women beneficiaries and it is consistent with the findings of Quisumbing and De la Brière (2000) that showed that the wife's education and work experience prior to the marriage is positively associated with her making decisions solely.

Nonetheless, even if beneficiaries make fewer decisions than non-beneficiaries regarding personal expenditure, this research suggested that their situation has improved as a result of the transfers, as beneficiary B9 $(43,9$ children) from Fortaleza explained:

"The support is really good, for me and for many women I know. Some women take more care, and their children, they feel in a safe place, knowing they will have the money. I feel more appreciated at home. I'm happy to 
receive [the transfers] and my family [is happy] too. When I have my money I have more autonomy, I can buy what I want. There are many women that claim the money is too little, they are ungrateful. They don't have enough because they don't organise themselves. Some of them buy and want to pay later, and later they can't pay back. For me, this money is for school supplies and food."

In the area of expenditure on children, 24 out of $30(80 \%)$ beneficiaries from Oportunidades and 28 out 30 (93\%) of non-beneficiaries could make their own decisions. In Brazil, 25 out of 30 (83\%) beneficiaries from Bolsa Família and 27 out of $30(90 \%)$ non-beneficiaries could decide on their own. The pattern in both countries showed that women have a high percentage of decision-making power; however, the beneficiaries in both countries reported making fewer decisions than the non-beneficiaries. Interviewees had the idea that women know better what to do and buy than men, as beneficiary M3 (42, 4 children) from Campeche said: "When women get the money they buy food, they care more about their children's nutrition than men." This finding is in line with Adato and Roopnaraine's (2010) research, which pointed out that women make these decisions since the mothers know best what is needed in the house.

In the area of durable purchases, 21 out of $30(70 \%)$ beneficiaries from Oportunidades and 22 out of $30(73 \%)$ non-beneficiaries reported making decisions. In the case of Brazil, 21 out of $30(70 \%)$ beneficiaries from Bolsa Família and 26 out of $30(87 \%)$ non-beneficiaries reported the ability to make decisions regarding durable purchases. While in Mexico there was no difference between the decisions making by beneficiaries and non-beneficiaries, in Brazil there was a visible difference. Bolsa Família beneficiaries made significantly fewer decisions in this area. These results were consistent with the findings of Gómez de León and Parker (1999). Their research found that decisions regarding large household expenditures (e.g. House repairs, durable purchases) were more likely to be made by the husband alone.

The fact that women were more likely to decide on food expenditures, personal items and expenditure on children and less likely to decide on durable goods, is consistent with the theory of "orchestration power" by Wolley and Marshall (1994). Men seem to have more power to make the "important" decisions, while women make the "unimportant" and time-consuming decisions such as deciding what to buy for food or making children's decisions. As non-beneficiary B38 (30, 1 child) from Fortaleza explained: "In Brazil education is generally a women's area, also paying the bills. Men prefer not to "waste time" with that." In Quixadá, beneficiary B18 (38, 5 children) said: "I decide everything in my house. He is not interested." 
In the area of savings, women reported having the least control of all areas analysed. In Mexico, 15 out of 30 (50\%) beneficiaries and 12 out of 30 (40\%) nonbeneficiaries reported being able to control some money for savings. In Brazil, 14 out of 30 (47\%) beneficiaries and 17 out of 30 (57\%) non-beneficiaries could manage the savings. While in both countries there was only a $10 \%$ difference between the groups, it is interesting to note that beneficiaries in Mexico made more decisions than the non-beneficiaries; while in Brazil the opposite situation is true. In Brazil, non-beneficiaries make more decisions than beneficiaries. This could point to a positive effect of the Oportunidades programme, in the sense that beneficiary women have extra resources, and also could be a consequence of the educational talks they receive, which encourage women to save. This comment from beneficiary M26 (33, 3 children) in Tenabo showed the general feeling of beneficiary interviewees: "To be honest, I do save, for a disease or something, I have a little bit saved." On the other hand, non-beneficiary M38 (36, 2 children) from Campeche pointed out the challenging economic conditions they face: "I would like to [save], but now it is very difficult." These findings furthermore suggested the lack of saving decisions as a consequence of cultural norms among the poor, and the lack of opportunity to save because of very low incomes among the poor, as this comment from non-beneficiary B39 (27, 1 child) from Fortaleza showed: "In Brazil people are not used to saving."

\subsubsection{Women's Attitudes and Views About the CCTs' Money}

This qualitative research also discovered that women in the state of Campeche are open to their husbands about receiving the Oportunidades transfers. In Mexico, husbands are aware of the women receiving the money and perceive it as an extra help for their children, money which should be channelled towards their children's nutrition and education. This perception is positive, and women report feeling more valued and appreciated in their households as they now contribute to the general budget, as beneficiary M14 (36, 4 children) from Hecelchakán commented: "Sometimes my husband doesn't have a job and he and my children are happy because they know that there's some money anyways [Oportunidades transfers]; it's a way of supporting my home."

This finding is closely supported by the qualitative research of Maldonado et al. (2006), who found no strong evidence of a rise of domestic conflict linked to Oportunidades' transfers. They suggest that the transfers are viewed by men as expressly intended for the benefit of the children, "not as money belonging to their mothers." Their report states that since the women merely administered the funds for the education and well-being of their children, this was not seen as a cause of conflict. In our evaluation, results were similar. As beneficiary M27 (40, 4 children) from Tenabo stated: "Husbands are happy that their family are receiving an extra 
income, and they know that such money does not have to do with them, but with the wellbeing of their children."

In contrast to Mexico, these findings suggested that beneficiaries in Brazil hide the money of Bolsa Família in order to be able to buy things for the house when they run out. A large number of Bolsa Família beneficiaries mentioned that they do not tell their husbands they are getting the governmental help. They said if the husbands knew, they would stop buying the necessary items for the household and they would say "Now you have your money, so use it, you don't need mine." As beneficiary B26 (32, 4 children) from Mange-Seco confessed: "I buy things, but hiding, I say my sister gave it to me [milk, shoes for the children]. If he knew he would go for Cachaça (local alcohol) instead of buying the food we need.

Several beneficiaries said that they used the money to buy food or children's clothing, but they did it without their spouses knowing. If the spouse discovered food or clothes they did not buy, beneficiaries lied and said it was a gift from their relatives (sister, mother, etc). These findings suggested a lower level of empowerment in decision-making in Ceará, where women were afraid of "owning" something since they believed if they had something, their spouses or partners would stop providing. As beneficiary B6 (35, 2 children) from Fortaleza (who hid her money) explained: "My husband did not allow me to spend on anything. I thanked God when Bolsa [Família] arrived."

\subsubsection{Decision-Making Regarding Children's Issues}

In the area of children's issues, questions were asked regarding the areas of: 1) school attendance, 2) health care attendance, 3) clothing and school items purchases, and 4) medicines purchase.

The findings suggested that both beneficiaries and non-beneficiaries in Mexico and Brazil have a high decision-making power when it comes to children's issues. Decisions in all areas of children's issues were mostly taken by the mothers. This showed a highly gendered decision-making process in the households.

Education seemed to be of high value among both beneficiaries and nonbeneficiaries in Mexico. When asked about whether or not they would allow their children (both boys and girls) to go to school, all beneficiaries said they allowed their children to go to school and that education was a priority. Beneficiaries answered in the following way: "Yes, I make my children go to school because education is very important." (M6 - beneficiary Campeche, 32, 3 children) and "Logically, education is the first thing." (M22 - beneficiary Tenabo, 51, 5 children). 
In the case of Ceará, all beneficiaries reported being able to make decisions regarding their children's school attendance, health care attendance, and purchase of clothing, school items and medicines; except one beneficiary who said it was her husband who was in charge of buying their children's clothes and school materials. In general, beneficiaries commented that they were grateful for Bolsa Família, as beneficiary B1 (39, 5 children) in Fortaleza reported:

"I thank God I get Bolsa and I use the money for good things, paying the gas, etc. However, I want my children to go to school to learn regardless [of Bolsa Familia]. I didn't study, and I want my children to have that opportunity. Children need to study, the world is difficult if you know nothing."

Table 5.1 Interviewees' self-reported decision-making power in the area of children's issues ${ }^{48}$

\begin{tabular}{lllllllllcc}
\hline \multirow{2}{*}{ Mexico } & & \multicolumn{2}{c}{$\begin{array}{c}\text { School } \\
\text { Attendance }\end{array}$} & $\begin{array}{c}\text { Health Care } \\
\text { Attendance }\end{array}$ & $\begin{array}{c}\text { Clothing/School } \\
\text { Items Purchase }\end{array}$ & $\begin{array}{c}\text { Medicines } \\
\text { Purchase }\end{array}$ \\
\cline { 3 - 10 } & Yes & No & Yes & No & Yes & No & Yes & No \\
& $\begin{array}{l}\text { Beneficiaries } \\
\text { Brazil }\end{array}$ & 30 & 0 & 30 & 0 & 30 & 0 & 30 & 0 \\
& $\begin{array}{l}\text { Non- } \\
\text { Beneficiaries } \\
\text { Beneficiaries }\end{array}$ & 30 & 0 & 30 & 0 & 30 & 0 & 30 & 0 \\
& $\begin{array}{l}\text { Non- } \\
\text { Beneficiaries }\end{array}$ & 30 & 0 & 30 & 0 & 29 & 1 & 29 & 1 \\
\hline
\end{tabular}

Source: Author's own data

Beneficiary B13 (47, 3 children) from Quixadá said: "Bolsa Família is important, it helped a little bit. Everything that is extra income is important. Now I don't worry, I can buy notebooks, etc. Everything goes to my children's needs."

These results about children's decisions showed that traditionally women have taken care of this domestic area. However, these results are also in line with the focus of Oportunidades and Bolsa Família on education and health care for children. Women seemed to be very aware of the importance of education and health for their children and this could be also influenced by the objectives of the programmes.

48 These results are condensed from Table A5.2 which can be viewed in detail in Annex 6. 


\subsubsection{Decision-Making Regarding Personal Decisions}

In the area of personal decisions, questions were asked regarding the following areas: 1) occupation, 2) participation in activities, and 3) ability to choose friends.

It is interesting to note that in both Mexico and Brazil beneficiaries seemed to be less able to make decisions regarding personal decisions than non-beneficiaries. Table 5.2 shows that in Mexico, 27 out of 30 beneficiaries (90\%) and nonbeneficiaries reported being able to choose their occupation. ${ }^{49} 28$ out of 30 beneficiaries $(93 \%)$ and all non-beneficiaries reported being able to participate in activities they liked. Finally, 29 out of 30 beneficiaries (97\%) and all nonbeneficiaries reported being able to choose their friends. Nonetheless, while 59 out of $60(98 \%)$ women reported being able to choose their friends, in a more detailed analysis not all of them reported being able to meet female or male friends. This could point to the fact that in their minds they feel empowered even if they are constraint by social and cultural norms. A deeper analysis of their ability to meet friends and relatives is provided in the mobility section of this chapter. ${ }^{50}$

Table 5.2 Interviewees' self-reported decision-making power in the area of personal decisions

\begin{tabular}{clcccccc}
\hline & & \multicolumn{2}{c}{$\begin{array}{c}\text { Choose } \\
\text { Occupation }\end{array}$} & $\begin{array}{c}\text { Participation in } \\
\text { Activities }\end{array}$ & \multicolumn{2}{c}{$\begin{array}{c}\text { Ability to Choose } \\
\text { Friends }\end{array}$} \\
\cline { 3 - 8 } & Yes & No & Yes & No & Yes & No \\
\multirow{2}{*}{ Mexico } & Beneficiaries & 27 & 3 & 28 & 2 & 29 & 1 \\
\cline { 2 - 8 } Brazil & Non-Beneficiaries & 27 & 3 & 30 & 0 & 30 & 0 \\
& Beneficiaries & 26 & 4 & 28 & 2 & 23 & 7 \\
\cline { 2 - 8 } & Non-Beneficiaries & 28 & 2 & 29 & 1 & 26 & 4 \\
\hline
\end{tabular}

Source: Author's own data

In Brazil, 26 out of 30 (87\%) beneficiaries and 28 out of 30 non-beneficiaries (93\%) reported being able to choose their occupation. 28 out of 30 beneficiaries (93\%) and 29 out of 30 non-beneficiaries (97\%) reported being able to participate in activities they like. Interestingly, in the area of ability to choose their friends, only 23 out of 30 beneficiaries $(77 \%)$ and 26 out of 30 non-beneficiaries $(87 \%)$ reported being able to choose them. In Ceará, this research suggested that there is empowerment within the household, but not outside. Women could make most decisions regarding the needs of the household (i.e. food expenditure, what to prepare,

\footnotetext{
${ }^{49}$ These results are condensed from Table A5.3 which can be viewed in detail in Annex 6.

${ }^{50}$ In the mobility section, the ability of beneficiaries and non-beneficiaries to meet male and female relatives, and male and female friends is analysed.
} 
children's issues, etc.) but they could not go outside freely, decide to participate in activities and choose their own friends, particularly if they were men. These findings suggested that women did not go out of the house if their husbands did not allow them in order to keep the domestic peace, as beneficiary B13 (47, 3 children) from Quixadá commented: "There are some people that my husband doesn't like. He doesn't let me go out with them [single female friends]. He doesn't let me be friends with women who do what they want. I don't see them to avoid problems with him."

Our findings suggested that in Brazil men told their wives or partners which friends they could see. If the friends were female and single, husbands regularly did not like them: they thought if they went out with their women, they would flirt with other men, as non-beneficiary B38 (30, 1 child) from Fortaleza shared: "He doesn't accept all my friendships. If there are women who drink, he doesn't accept that I go out with them, he thinks I'll do the same." Some women have interiorised this feeling, as B18 beneficiary $(38,5$ children) from Quixadá showed: "There are many women that are all day long on the street. I don't like that and my husband neither."

\subsubsection{Decision-Making About Reproductive Health}

In the area of reproductive health, questions were asked regarding: 1) women's use of contraception, 2) control over sexual relations, 3) control over child-bearing, and 4) attendance at health check-ups. Figure 5.2 provides an overview of the interviewees' responses. ${ }^{51}$

Our findings showed that in Mexico, 23 out of 30 beneficiaries (77\%) reported using contraception, while 28 out of 30 non-beneficiaries (93\%) use contraception. 26 out of 30 beneficiaries $(87 \%)$ reported having control over sexual relations, while 29 out of 30 non-beneficiaries (97\%) said they could decide whether or not they wanted to have sexual relations. 26 out of 30 beneficiaries (87\%) reported having control over child-bearing decisions - whether or not to have a baby and when to have it, while 28 out of 30 non-beneficiaries (93\%) reported being able to make this decision. Finally, 27 out of 30 beneficiaries $(90 \%)$ and all non-beneficiaries reported that they attended periodic health check-ups. It is noteworthy that in Mexico, nonbeneficiaries reported higher levels than beneficiaries of decision-making in all four areas of reproductive health issues. This could be due to the low socioeconomic level of the beneficiaries. In this case, even if the Oportunidades programme provides educational talks and has the conditionality of attending health check-ups, non-beneficiaries seemed to have a higher decision-making level.

\footnotetext{
51 These results are condensed from Table A5.4 which can be viewed in detail in Annex 6 .
} 
Figure 5.2 Interviewees' self-reported decision-making power in the area of reproductive health

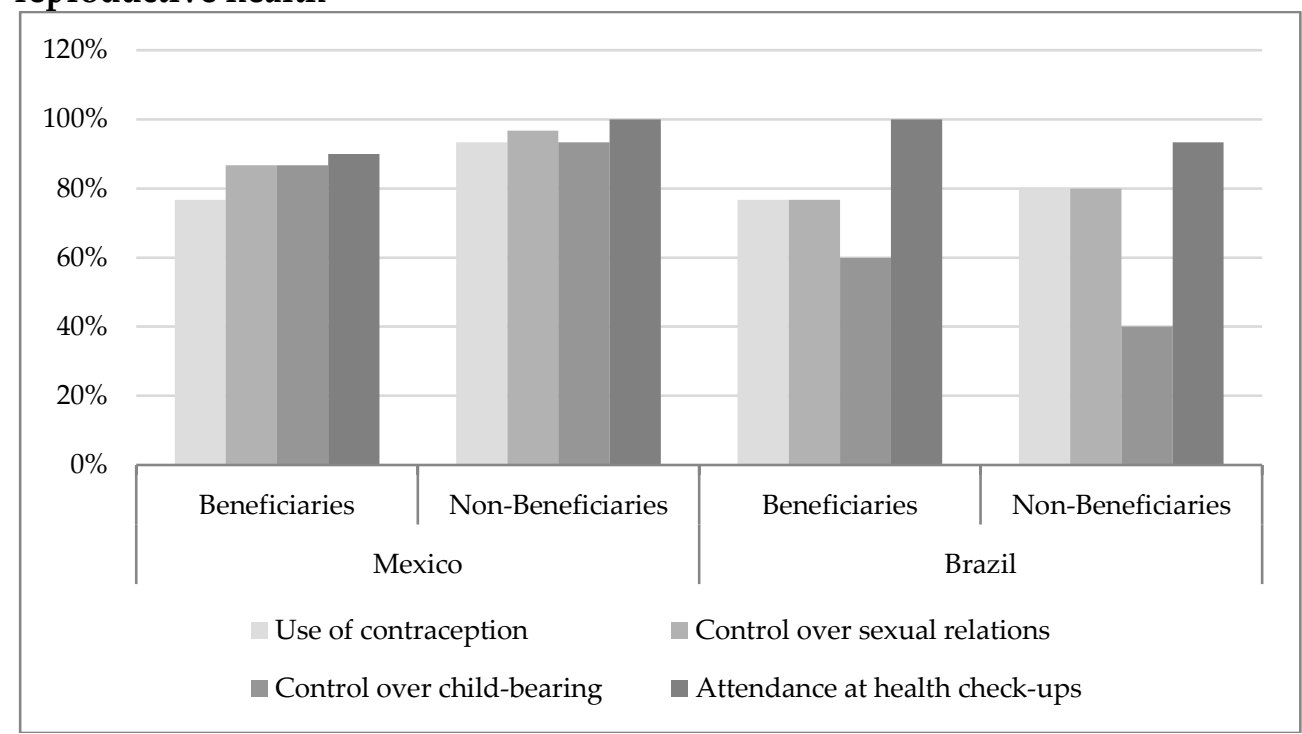

Source: Author's own data

In the case of Brazil, this pattern was the same in the areas of contraception use and control over sexual relations: 23 out of 30 beneficiaries (77\%) and 24 out of 30 nonbeneficiaries $(80 \%)$ reported contraception use, and the same number of interviewees reported having control over sexual relations. These results differ from the findings on contraception of De Brauw et al. (2014), who found that beneficiaries had a $10-11 \%$ higher decision-making power in the area of contraception than non-beneficiaries. However, our findings suggested that women -both beneficiaries and non-beneficiaries- in urban areas have a higher decision-making power in contraception than women in semi-rural and rural areas. This finding is in line with the results of De Brauw et al. (2014), who found that in urban areas the effects on contraception are larger and more highly significant than in their aggregate estimates, with an increase of $16-18 \%$.

In the areas of control over child-bearing and attendance at health check-ups, the numbers reversed: 18 out of 30 beneficiaries reported having control over childbearing, against only 12 out of 30 non-beneficiaries. In the area of health check-ups attendance all beneficiaries reported to attend health check-ups, while only 28 out of 30 non-beneficiaries attended them. This situation could be explained by the extra awareness Bolsa Família raises regarding reproductive health. However, it could also be that the beneficiary interviewees were afraid of saying they did not attend health check-ups since it is a programme conditionality. 
It is also noteworthy that in the case of Ceará, beneficiaries and non-beneficiaries in the three communities reported very low numbers of power over child-bearing decisions. Beneficiary B24 (36, 2 children) from Mangue-Seco shared with us: "I couldn't decide if I wanted to have sexual relations. If he wanted, I needed to do my 'obligation.' He raped me and I got pregnant with my first child." Many women shared similar stories. The general characteristic was that they got married when they were very young and that their husbands abused them and they could not say no because they were afraid, as beneficiary B26 (32, 4 children) from Mangue-Seco told us: "I was 21 when I got married. My opinion was not valued at home. He was stupid, and would force me to do my 'obligation,' and I was very afraid of him."

Our findings suggested that in the area of reproductive health, interviewees in Mexico -both beneficiaries and non-beneficiaries- seemed to have higher decisionmaking power. This could be explained by a higher access to education in Mexico, where emphasis is given to health education. Furthermore, access to education talks for women beneficiaries could be having the added benefit of making them aware of their rights, since one of the topics covered in the talks is reproductive health.

It is interesting to note in Figure 5.3 how Oportunidades beneficiaries seem to have a lower ability to use contraception than non-beneficiaries, except in the semiurban community of Hecelchakán, where all the interviewees reported having decision-making power in the area of contraception. In the case of Brazil, beneficiaries and non-beneficiaries had the same level of decision-making, except in the community of Quixadá, where non-beneficiaries reported a higher level. This could be explained by the fact that non-beneficiaries, in general, have higher levels of decision-making than beneficiaries. In the case of Hecelchakán, the high decision-making power of beneficiaries and non-beneficiaries alike suggested that this community had a very good health centre which was raising contraception awareness among the women. 
Figure 5.3 Interviewees' self-reported ability to use contraception

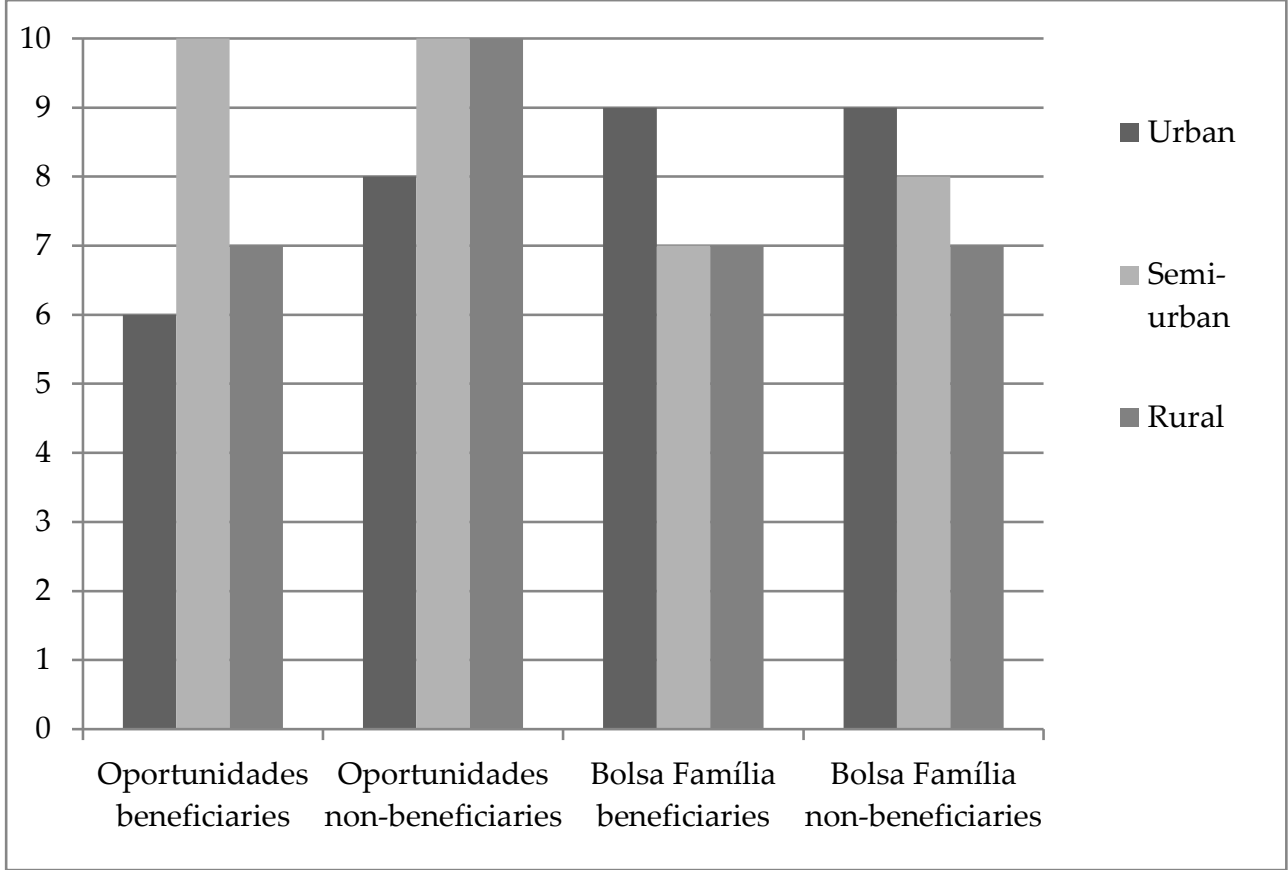

Source: Author's own data 


\section{Box 5.2 The case of sterilisation surgeries in Tenabo, Mexico}

In Tenabo we discovered a common pattern among the interviewees, both beneficiaries and non-beneficiaries: a high number of them (5 out of 10 beneficiaries and 4 out of 10 nonbeneficiaries) had had a sterilisation surgery. Trying to find out more about this procedure, we talked to medical doctors working in Campeche, and they said that during their medical training, they are told to ask women living in poverty -and try to convince them, if necessary- to have this kind of surgery. Normally, the surgery is given free of charge to women who have had more than 4 children or who are older than 37 years-old immediately after they give birth to their last child. We interviewed beneficiary M29 (43, 3 children) who told us that this surgery had been performed on her without her knowing and without her consent:

"When I had my third child, I was 37. I had a C-Section and went home. I tried to get pregnant for 5 years without luck. Last year 2011] a mobile health unit came to Tenabo. When I went for my Papanicolau ${ }^{52}$ I told them I couldn't get pregnant anymore and the nurse told me obviously I couldn't, since I had the surgery. I was shocked, I didn't know anymore which doctor had treated me, I didn't know who to blame. I talked to my husband and asked him if he knew, if they had asked him, and he said he did not know either. I was very sad but didn't do anything about it. I don't know who did it, what can I do? How can I sue them?"

This situation could be explained by the desire of the state to keep low birth rates for poor women. Nevertheless, it is outrageous and a human rights' violation that the government is implementing a state policy to sterilise poor women without their acknowledgement and consent.

Source: Author's own research

\subsubsection{Decision-Making About Mobility}

In the area of mobility, questions were asked regarding the following areas: 1) can women leave the house alone without permission? 2) can they leave the house alone with permission? 3) can they leave the house accompanied without permission? 4) can they leave the house accompanied with permission? 5) can they meet female relatives? 6) can they meet female friends? 7) can they meet male relatives? and 8) can they meet male friends? Figure 5.4 provides an overview of the interviewees' responses. ${ }^{53}$

\footnotetext{
52 Detection test for cervix-uterine cancer.

53 These results are condensed from Tables A5.5 and A5.6 which can be viewed in detail in Annex 6 .
} 
Figure 5.4 Oportunidades' and Bolsa Família's beneficiaries and nonbeneficiaries self-reported decision-making power in the area of mobility

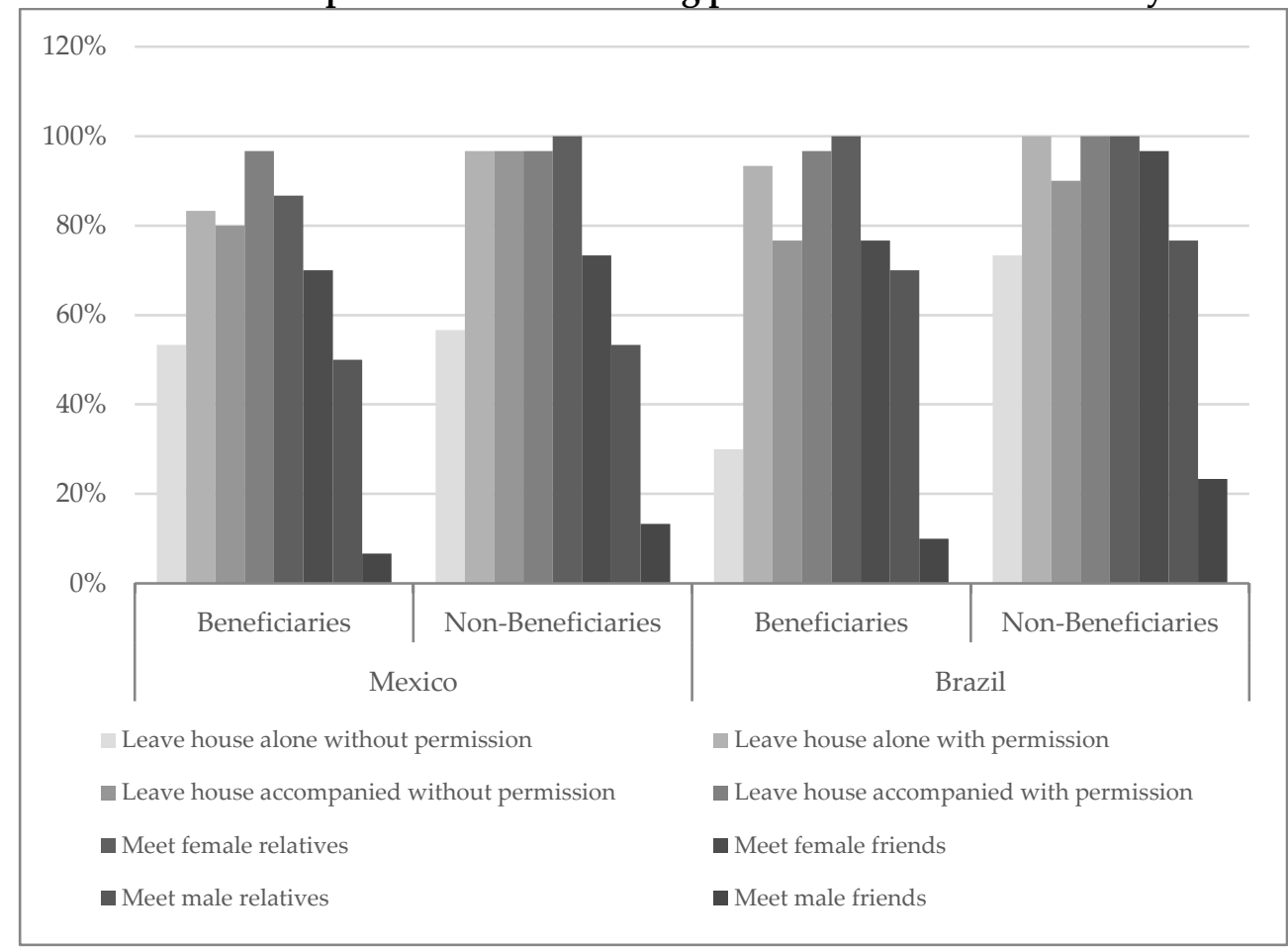

Source: Author's own data

The findings showed that in Mexico 16 out of 30 (53\%) beneficiaries and 17 out of $30(56 \%)$ non-beneficiaries could go out of their house alone without permission, while 25 out of $30(83 \%)$ beneficiaries and 29 out of $30(96 \%)$ non-beneficiaries could go out of their house alone after asking for permission. If they were leaving the house accompanied -for example, with their children or a relative- 24 out of 30 $(80 \%)$ beneficiaries and 29 out of $30(96 \%)$ non-beneficiaries could go without permission, and 29 out of $30(96 \%)$ both beneficiaries and non-beneficiaries could go after asking for permission. This showed that women normally were not allowed to go out of the house alone if they did not ask for permission from their spouses beforehand. This could be explained due to the cultural and traditional background of Mexico, where macho attitudes persist and men, mostly in extreme poverty contexts, see women as belongings. As these beneficiaries reflected: "If I wanted to go out, he would hit me, I was very stupid, now not anymore, if someone would hit me, I'd hit him twice." (Campeche beneficiary M2, widow, 41, 3 children) and "I need to ask him for permission [if I want to go out]. If he gives permission, yes, if not, no, so that there are no problems." (Tenabo beneficiary M21, married, 60, 8 children). 
Around 57\% of non-beneficiaries reported that they could leave the house without asking for permission but they "let their husbands know" that they were going out. Non-beneficiary M35 (46, 2 children) from Campeche shared: "I can go out, but I always let them [my family] know where I am going, everyone in my house does that. Campeche has become a dangerous city. I always tell him [my husband] where I am going and with whom, for safety reasons."

Regarding visiting relatives and friends, 26 out of $30(87 \%)$ beneficiaries and all non-beneficiaries reported being able to visit female relatives, while only around 21 out of $30(70 \%)$ beneficiaries and non-beneficiaries reported being able to visit female friends. When asked about whether or not she could visit female relatives, 52 year-old beneficiary M8 from Campeche (widow, 3 children) answered: "it wasn't like that back then [when she was young and married]."

While above $80 \%$ of the interviewed beneficiaries and non-beneficiaries could meet female relatives and around $70 \%$ of them could meet female friends, the numbers dropped significantly regarding meeting or visiting male relatives and male friends. 15 out of 30 beneficiaries and 16 out of 30 non-beneficiaries reported to be able to meet male relatives, nevertheless only two out of $30(7 \%)$ beneficiaries and four out of $30(13 \%)$ non-beneficiaries said they were able to meet or visit male friends. Noteworthy is the fact that the only two women who reported being able to meet male friends were from the urban community (Campeche). In the semiurban and rural areas none of the beneficiaries reported to be able to meet male friends.

$53 \%$ of non-beneficiaries reported they could meet male relatives. However, their comments suggested that this is culturally frowned upon, as non-beneficiary M34 (31, 2 children) from Campeche said: "[I can meet male relatives] only if their wives are there. I only meet my brothers-in-law if my sisters are there." The traditional idea of married women (or with live-in partners) not being trusted to have contact or friendships with other men is still prevalent. When asked about meeting male friends, the most common answers were "No, I don't have any," or "I don't, you need to set boundaries."

It is noteworthy that in all categories, non-beneficiaries always had higher levels of decision-making frequencies than beneficiaries. This could be explained due to the extreme poverty situation faced by beneficiaries and their lower education levels.

In the case of Brazil, 9 out of 30 (30\%) beneficiaries and 22 out of $30(73 \%)$ nonbeneficiaries could go out of their house alone without permission, while 28 out of $30(93 \%)$ beneficiaries and all non-beneficiaries could go out of their house alone after asking for permission. If they were leaving the house accompanied (e.g. with 
their children or a relative) 23 out of $30(76 \%)$ beneficiaries and 27 out of $30(90 \%)$ non-beneficiaries could go without permission and 29 out of 30 (96\%) beneficiaries and all non-beneficiaries could go after asking for permission. It is interesting to note that the number of beneficiaries who were able to leave the house without permission was radically low (around 30\%); and the lowest number was in Fortaleza, the urban community. This could be explained due to the fact that Fortaleza is a dangerous city and women were afraid to go out alone. These women live in favelas, which are the most dangerous parts of cities, and especially well-known for their high levels of violence. As beneficiary B6 (35, 2 children) from Fortaleza said: "I always ask for permission, afterwards I can go." Regarding visiting relatives and friends, all beneficiaries and non-beneficiaries reported being able to visit female relatives, and 23 out of $30(76 \%)$ beneficiaries and 29 out of $30(96 \%)$ non-beneficiaries reported being able to visit female friends. In the case of male relatives and friends, 21 out of $30(70 \%)$ beneficiaries and 23 out of $30(76 \%)$ nonbeneficiaries reported to be able to meet male relatives, while only three out of 30 $(10 \%)$ beneficiaries and seven out of $30(23 \%)$ non-beneficiaries said they were able to meet or visit male friends.

In Brazil, both beneficiaries and non-beneficiaries seemed to have higher levels of decision-making in decisions of mobility than their counterparts in Mexico. However, in their comments we could see some nuances. Beneficiary B15 (31, 4 children) in Quixadá said: "I can meet male relatives but not male cousins [only brothers and father]." In the case of male friends, only $10 \%$ of beneficiaries reported being able to meet them. Their reasoning seemed to be in-tune with the macho culture of Brazil and Latin America in general, as beneficiary B5 from Fortaleza (47, 3 children) explained: "I couldn't go out, meet female friends. My husband was very jealous. Obviously I couldn't meet male friends, my husband was very controlling, he did not allow me to talk to other men or leave the house."

It seemed that both Mexican and Brazilian societies judge women who meet other men very harshly. The main paradigm is that a married woman should only interact with her husband and not have male friends. Having male friends is equated with cheating on the partner. As beneficiary B15 from Quixadá explained: "If someone sees a woman with another man, they think she cheats on her husband." Nonetheless, while $90 \%$ of women reported not being able to meet male friends, there might be some exceptions, as beneficiary B1 (39, 5 children) from Fortaleza explained: "My male friends take me to run my errands. My husband gets jealous but he accepts it."

Even if a large number of women reported being able to meet female friends, when they talked with us, they painted a different reality. Men in Ceará seem to have a problem with their partners having women friends, as non-beneficiary B38 in 
Fortaleza said: "I meet female friends but he [her husband] doesn't like it, he thinks we will flirt." Beneficiary B12 (32, 6 children) from Quixadá shared the same problem: "He doesn't accept all my friendships. If there are women who drink, he doesn't accept that I go out with them, he thinks I'll do the same."

In the area of female friendships, these non-beneficiaries shared: "I can meet girl friends but only at home. My husband says which friends he likes. I can't see the ones he doesn't like. If they're single he doesn't like them, he thinks we will go out and flirt," (B3927, 1 child, Fortaleza). "My husband is always saying my friends are bad influences, so I stopped seeing them," (B37 - 31, 2 children, Fortaleza) and "I can meet female friends only if I think she is a serious person. He trusts me because he knows I have never done something wrong [as in cheating]." (B44 - 57, 2 children, Quixadá).

It seemed that even if most women reported being able to meet female friends, at the end they did not do it in order to keep the domestic peace or they just met the friends that had been "approved" by their husbands. Regarding meeting male friends, a high number of non-beneficiaries in the urban case (50\%) said they could meet them. However, deeper analysis suggested this could be only a perception, as exemplified by these non-beneficiaries from Fortaleza: "I have never met a male friend, but I think I could if I wanted to," (B35 - non-beneficiary [who reported ability to meet male friends], 47, 4 children) and "I do not do it [meeting male friends]. I think if I did it, it would cause fights." (B38 - 30, 1 child). Other women stopped having male friends when they got married. They believed this was normal and expected from them since they were "serious" people. Reflecting on her lack of male friends, beneficiary B12 in Quixadá reflected: "I had male friends when I was single. There's a lot of gossip. I don't like people talking about me. [So now] I always go out with my mother."

\subsubsection{Decision-Making Areas}

Figure 5.5 summarises who interviewees perceived made most decisions in the household. ${ }^{54}$ It shows that in Mexico, both beneficiaries (16 out of 30) and nonbeneficiaries (17 out of 30) reported to make most decisions jointly. This finding is in line with Gómez de León and Parker's (1999) research, which showed that there is an apparent "jointness" of decision-making in Mexico, with the dominant response being that decisions are taken jointly by husband and wife. However, in Oportunidades households, women reported less independence in decisionmaking. Kabeer warns that results should be interpreted cautiously, since they "tell us very little about the subtle negotiations that go on between women and men in their private lives. Consequently, they may underestimate the informal decision-

\footnotetext{
54 These results are condensed from Table A5.7 which can be viewed in detail in Annex 6 .
} 
making agency which women often exercise" (Kabeer, 1999: 447). Changes in power relations within the household are "often precisely about changes in informal decision-making, with women opting for private forms of empowerment which retain intact the public image, and honour, of the traditional decision-maker but which nevertheless increase women's "backstage" influence in decisionmaking processes" (Kabeer, 1999: 447-448).

\section{Figure 5.5 Interviewees' self-reports on person who makes most decisions in the household}

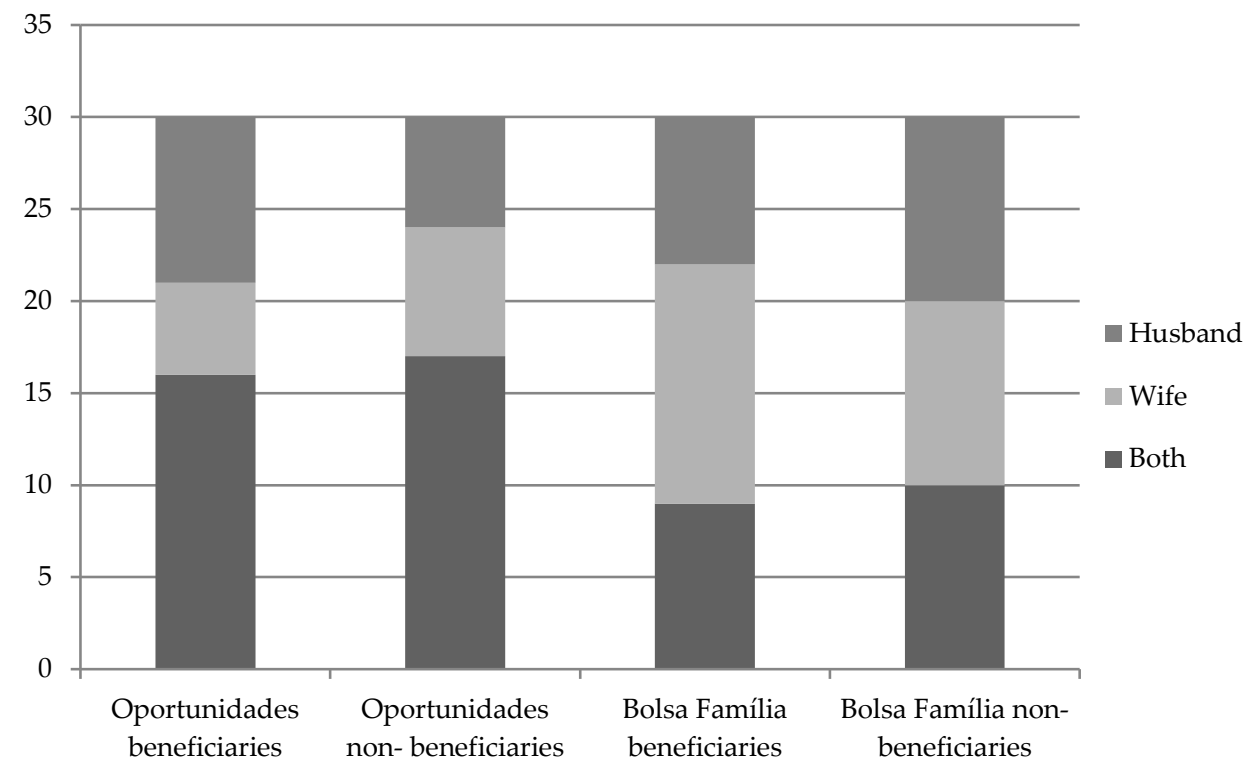

Source: Author's own data

In the case of Brazil, only nine out of 30 beneficiaries, and a third of nonbeneficiaries reported to make decisions jointly. Interestingly, beneficiaries reported making most household decisions themselves (13 out of 30). In the case of non-beneficiaries one third of them reported making most decisions themselves, another third reported the husbands making the decisions and the last third said they were making joint decisions. Contrary to Mexico, in Brazil beneficiaries reported the highest numbers of wife alone making most household decisions. This could be explained by the fact that traditionally, in Mexico it is more culturally accepted that both husbands and wives make household decisions jointly, while in Brazil it is seen as a question of conflict of power. In Brazil, women who reported making most decisions generally said it with pride, along the lines of beneficiary B18 in Quixadá (38, 5 children): "I command more, with certainty!" However, other women were more reserved and showed some nuances to this attitude, as non- 
beneficiary B31 (34, 3 children) from Fortaleza shared: "Within the household we make joint decisions, but for the outside supposedly my husband's opinion is heavier. Because of our culture, the man has to be the boss in everything."

Figure 5.5 suggests that while in Mexico there is mostly a "jointness" of decisionmaking, in Brazil is mostly the husband or, in some cases, the wife, making the decisions, rather than the couple together. It is important to note that the process of empowerment should mean that women have more control of their choices. However, it does not necessarily need to mean that there should be no communication between spouses or that the woman should be the sole decisionmaker in the household. Ideally, spouses/domestic partners should achieve a balance where most important decisions should be made jointly; and women should be able to make their own strategic and meaningful life choices -such as whether to participate in the paid labour market or not, whether to marry or not, whether to have children and when to have them.

Table 5.3 Reported wife and husband/partner's decision-making areas in household

\begin{tabular}{|c|c|c|c|}
\hline Wife & $\begin{array}{l}\text { Frequency } \\
(\mathrm{N}=120)^{*}\end{array}$ & Husband/Partner & $\begin{array}{l}\text { Frequency } \\
(\mathrm{N}=120)^{*}\end{array}$ \\
\hline Education & 38 & Home improvement/Repairs & 39 \\
\hline $\begin{array}{l}\text { Children's issues } \\
\text { (bedtime, } \\
\text { punishments, } \\
\text { permissions, play } \\
\text { dates) }\end{array}$ & 37 & $\begin{array}{l}\text { Permissions (wife and } \\
\text { children) }\end{array}$ & 30 \\
\hline Children's clothing & 32 & Durable Purchases/Furniture & 15 \\
\hline Clothing & 30 & Travel/Holidays & 14 \\
\hline Food/Nutrition & 27 & Grocery shopping & 14 \\
\hline $\begin{array}{l}\text { Daily/Household } \\
\text { things }\end{array}$ & 18 & Education & 5 \\
\hline Home organisation & 15 & Clothing & 4 \\
\hline Health & 13 & Internet/Computer & 3 \\
\hline Family visits & 12 & Animal care & 2 \\
\hline Leisure activities & 10 & Cars & 1 \\
\hline Money expenditure & 6 & & \\
\hline
\end{tabular}

*Women could give as many areas as they wanted. Numbers may not total 120

Source: Author's own data

Table 5.3 suggests that there is a highly gendered decision-making process, where typically women are in charge of "domestic" areas, such as education, children's issues, nutrition, health, clothing and daily household decisions; while men are in charge of "bigger" decisions, such as home repairs, durable purchases and travels, and also of mobility permissions for wives and children. It is interesting to note 
that one fourth of interviewees reported their husbands/partners were in charge of giving permissions to them and their children. Furthermore, only $5 \%$ of interviewees could make money expenditure decisions.

In the end, this study shows three kind of scenarios according to the wives' economic and educational status. In households where the women had more education or where husbands worked further away, women managed to make more decisions on their own, as beneficiary M23 (31, 2 children) from Tenabo said: "I make most decisions because he's almost never at home. I know what we need and what is better to buy." In households where both women and men had the same education or economic level, most decisions were made together, as nonbeneficiary M35 (46, 2 children) from Campeche said, who reported making most decisions jointly: "I always tell my husband where I'm going, but he needs to tell me too what he's doing. I ask him for his opinion, but he needs to ask for my opinion too." And finally, in households where women had a lower education level, men seemed to be able to make most decisions on their own, as beneficiary M11 (60, 1 child) from Hecelchakán illustrated: "He says "this will be done" and that is done. Men think different, they do not care what you say."

\subsection{Discussion and Conclusions}

This chapter focused on patterns of decision-making in Campeche and Ceará, and on the potential changes that Oportunidades/Prospera and Bolsa Família can create in intra-household power distribution and decision-making processes by providing beneficiaries with more economic and, in some cases, educational resources.

Decision-making was categorised in five areas: 1) economic, measured by household expenditure, 2) familial, measured by decisions regarding children' issues, 3) personal, measured by ability to choose occupation, activities, and friendships, 4) reproductive, measured by ability to use contraception, control over sexual relations, child-bearing, and attendance at health check-ups, and 5) sociocultural decisions, measured by freedom of mobility.

The findings suggested that decision-making happens in gender-specific ways, showing a prevalence of traditional (patriarchal) gender norms. Both among beneficiaries and non-beneficiaries there is a highly gendered decision-making process by which women are more likely to decide on food expenditure, personal items and expenditure on children, and less likely to decide on durable goods, house repairs or travels. These results are consistent with the theory of "orchestration power" by Wolley and Marshall (1994). 
Regarding attitudes towards the CCT money, the field work revealed that in Mexico women are open about receiving the money, and men accept it at "children's money" and do not perceive it as a threat. This finding is consistent with Maldonado et al. (2006), who suggest that men view the money specifically for the children's well-being and did not perceive it as a cause of conflict. However, in the case of Brazil, women hide the money and do not tell their partners about it, suggesting a lower level of empowerment and bargaining power.

The research showed that the areas where there women had the least decisionmaking power were in the ability to choose friends, in the reproductive health area -especially in Brazil, and in the ability to meet male relatives and friends. Regarding reproductive decisions, non-beneficiaries in both countries seemed to have more control over contraception use, differing from the findings of De Brauw et al. (2014), who found that beneficiaries had a higher decision-making power in the area of contraception than non-beneficiaries. These findings also suggested that women in Brazil -both beneficiaries and non-beneficiaries- in urban areas have a higher decision-making power in contraception than women in semi-rural and rural areas. However, the situation in Mexico is reversed: women in semi-urban and rural areas have a higher access to contraception. In addition, the findings showed that in Mexico women expressed making mostly jointed decisions, while in Brazil the decisions were mostly made by either the wife or the husband.

Finally, three kind of scenarios emerged according to the wives' economic and educational status: in households where the women had more education or where husbands worked further away, women managed to make more decisions on their own. In households where both women and men had the same education or economic level, most decisions were made together. And in households where women had a lower education level, men seemed to be able to make most decisions on their own. These findings are consistent with Quisumbing and De la Brière's (2000) whose research suggest that the wife's education and work experience prior to marriage is positively associated with her making decisions solely.

The heterogeneity of these results showed that empowerment is class-, contextand culturally-specific. Cultural and social capital matter, and there is still a predominance of patriarchal gender norms. In Mexico there seemed to be more empowerment for women both within and outside of the household. In Brazil it seemed there is empowerment within household, but not outside. Women made more decisions about money and home issues, but they could not go outside without permission in order to keep domestic peace. However, women in Brazil felt their opinion had the same weight as their husband's, or even more weight. But for the outside, the opinion of the husband needed to seem stronger. 
In conclusion, the findings evidenced the persistence of traditional gender norms that disempower women in intra-household decision-making, especially women who lack formal education, despite CCT receipt. The findings also showed that the context in which women live -urban vs. rural community- matters to the effect CCTs have on women's empowerment. 


\section{Chapter 6. CCTs and Women's Experiences of Empowerment}

\subsection{Introduction}

Empowerment is seen as "the process by which the powerless gain greater control over their lives, gaining power to achieve goals and ends" (Kishor and Gupta, 2004: 694). Thus, exercising choice is seen as gaining power. Empowerment broadly means having increased life options and choices, gaining greater control over one's life, and generally attaining the capability to live the life one wishes to live. These definitions imply that empowerment is a dynamic process of change whereby "those who have been denied the ability to make choices acquire such an ability" (Kabeer, 1999: 437).

The objective of this chapter is to analyse the interviewees' own perceptions of empowerment, self-awareness and self-worth; 55 as well as examine how they feel their opinions are valued within their families and households. Furthermore, we want to find out if conditional cash transfers, such as Oportunidades and Bolsa Família, enable empowerment processes in the households where they are received and what are the personal perceptions and experiences of empowerment of the interviewees. The findings suggest that through CCT receipt and participation in educational talks some processes are taking place, which we call: empowerment awareness, domestic violence awareness, and parenting empowerment. In addition women perceived an increase in their self-worth and more respectful family relations.

Using Kabeer's empowerment framework as a conceptual framework-addressed in chapter 3, this chapter analyses whether and how CCTs (resources) help women to achieve their empowerment (agency), measuring it in the psychological dimension through indicators such as self-esteem, self-worth, and own perception of change (outcomes). The study focuses on the different effects that can be achieved in diverse contexts, such as in different countries (Mexico and Brazil), and in different communities within the same country (i.e. rural, semi-urban and urban). This chapter is structured in the following way: the second section states the research methods. The third section presents the findings, and the final section states the concluding remarks.

\footnotetext{
${ }^{55}$ Self-worth will be defined as the sense of one's own value or worth as a person. Self-worth is less about measuring oneself based on external actions and more about valuing one's inherent worth as a person. In other words, self-worth is about who we are, not about what we do, even though the two are related.
} 


\subsection{Methods}

The analysis in this chapter focuses on the psychological and behavioral dimensions of empowerment, analysing the findings regarding women's own perceptions of empowerment, self-awareness and self-worth, in addition to their perceptions of their opinions being valued within their households. We will also focus on whether or not conditional cash transfers, such as Oportunidades and Bolsa Família, enable personal empowerment processes in the households, and if so, under what circumstances such processes take place.

The methods used in order to assess the consequences of conditional cash transfers on women's empowerment is based on case study field work. Data for this study come from the qualitative analysis of semi-structured in-depths interviews with 120 beneficiaries and non-beneficiaries of the Oportunidades and Bolsa Família programmes conducted in 2012-as explained in detail in chapter 3.

The analysis in this chapter focuses on the findings regarding the psychological dimensions of empowerment, especially on interviewees' own perceptions of empowerment, and the effect that beneficiaries perceive Oportunidades/Prospera and Bolsa Família are having on their personal empowerment, self-awareness and self-worth. The questions in the interviews in these areas fell in two categories: a) the area of own perceptions and experiences of self-worth and empowerment, and b) Oportunidades/Prospera's and Bolsa Família's effects on women's lives. The questions were open-ended and the interviewees could express their own ideas. This allowed us to have richer responses and to obtain a better understanding of the process of empowerment for the women interviewed in these communities.

It is important to notice the scope and limitations of this chapter. Since the late 1990s extensive research has been undertaken regarding the effects of CCTs in Mexico and Brazil, especially in the areas of health and education. Nonetheless, in the area of women's empowerment, there are major knowledge gaps that need to be filled. The effects of the programmes on the areas of women's own perception of empowerment has been under researched. In Brazil there has been no research in the area of women's empowerment. So far, the evaluation of Oportunidades and Bolsa Família on qualitative issues regarding women's empowerment has not been extensive nor systematised, thus providing a fertile ground for deeper research in this area. 


\subsection{Findings}

CCT programmes have as a main objective to increase the basic well-being and quality of life of families living in extreme poverty, especially in the areas of education, health and nutrition. These programmes target women as beneficiaries in order to improve the welfare of children and the family as a whole. In this sense, CCTs are not primarily concerned with women's empowerment, but rather with how women can facilitate the achievement of the main health, nutrition, and education goals of the programmes. However, as Kabeer (1999) states, there is a connection between poverty and disempowerment, since the inability to meet one's basic needs often rules out the exercise of meaningful choice. At the same time, there is a connection between gaining access to resources and empowerment: by having more control over resources, women may gain the ability to exercise choice. CCTs such as Oportunidades ${ }^{56}$ and Bolsa Família can, however, contribute to women's empowerment in some dimensions. Oportunidades and Bolsa Família put money in women's hands and encourage them to keep it and administrate it. In addition, they provide and require women's participation in educational talks regarding health, nutrition, and family planning.

This section provides the findings of this research on the effects of Oportunidades and Bolsa Família on the psychological dimension of empowerment (self-worth, opinion same weight as husband), and states the opinions and voices of the beneficiaries regarding how participating in these programmes has changed their lives (or not). We set out to explore how women beneficiaries and non-beneficiaries of both Oportunidades and Bolsa Família felt about themselves and their value in their households, in addition to the beneficiaries' perception of the transfers and the effects they have had on their lives. In order to do so, in the first part of this section, we discuss the findings related to the answers of beneficiaries and nonbeneficiaries regarding 1) own perception of opinion valued at home, and 2) perception of opinion having the same weight as their husbands'. The second part of the findings is related to the answers of only Oportunidades' and Bolsa Família's beneficiaries regarding 1) attendance at educational talks, whether they consider such talks useful, and things learnt from the talks, 2) change of habits and behaviour as a result of the talks, 3) change in feelings of appreciation since receiving the transfers, and 4 ) other perceptions.

\footnotetext{
56 Oportunidades' objectives state that one of the main aims of the programme is "strengthening the capabilities of beneficiary family members" (Oportunidades, 2006: 8). Through the adoption of a gender perspective the programme seeks "to promote the equal access of women to its benefits," recognising that "poverty acquires different forms according to the inequalities that prevail between the sexes" (Oportunidades, 2006: 8). One of the claims of the programme is to help empower the mothers and daughters of beneficiary families.
} 


\subsubsection{Self-Confidence and Self-Worth}

Table 6.1 suggests that in Mexico, when asked about whether or not they felt their opinion was valued at home, most women, both beneficiaries (27 out of 30) and non-beneficiaries (29 out of 30) had a high number of positive answers. ${ }^{57}$ Nevertheless, it is interesting to notice that in the case of beneficiaries, it seemed that only around half of the interviewees (16 out of 30) felt their opinion had the same weight as their husband's opinion. So, while they felt mostly valued, they also felt that their husband's opinion (13 out of 30 ) had more weight than theirs.

Table 6.1 Interviewees' own perceptions of opinion valued at home and if their opinion has the same weight as their husbands'

\section{Opinion valued Opinion same weight as husband} at home

\begin{tabular}{|llccccc}
\cline { 3 - 7 } Mexico & Yes & No & Same & Less & More \\
\cline { 3 - 7 } & Beneficiaries & 27 & 3 & 16 & 13 & 1 \\
& $\begin{array}{l}\text { Non- } \\
\text { Beneficiaries }\end{array}$ & 29 & 1 & 19 & 6 & 5 \\
\hline & Beneficiaries & 23 & 7 & 10 & 9 & 11 \\
\hline & $\begin{array}{l}\text { Non- } \\
\text { Beneficiaries }\end{array}$ & 26 & 4 & 17 & 9 & 4 \\
\hline
\end{tabular}

Source: Author's own data

This inconsistency was exemplified by beneficiary M11 (60, 1 child) from Hecelchakán, who even after answering that she felt her opinion was valued at home, responded when asked if her opinion was as important as her husband's: "No, not at all. Men think differently, they don't care about what you say." Beneficiary M26 (33, 3 children) from Tenabo, who also said she felt her opinion valued at home, stated: "He says 'Aquí mando yo' ['Here, I'm the boss'], his temperament is stronger than mine, so his opinion has more weight." In the case of Mexican beneficiaries, only one interviewee replied that she believed her opinion was more important than her husband's. It is important to keep in mind that most of these women stated that the decision-making process in their households was mostly joint by husband and wife.

When asked about why they felt their opinion was valued at home, most women in Mexico answered that it was because their children obeyed them and did as they said. As beneficiary M6 (32, 3 children) from Campeche said: "The children respect

\footnotetext{
57 These results are condensed from Table A6.1 which can be viewed in detail in Annex 6 .
} 
what I say and my husband supports what I decide." This research suggested that women in Mexico seemed to relate having their opinion valued at home with their children respecting and obeying them. One third of all interviewees mentioned that their children obeyed them as part of their feelings of value, so their feelings of value within the household seemed to be linked to their maternal role and acceptance of their authority by their children. As beneficiary M27 (40, 4 children) from Tenabo said: "I think my opinion is valued at home because my children obey what I say."

It is interesting to note that non-beneficiary interviewees showed higher rates of their opinion having the same weight as their husbands (19 out of 30) than beneficiaries (16 out of 30); and five out of 30 non-beneficiaries considered their opinion more important than their husband's, compared to only one beneficiary. These results could show a lower empowerment or lower self-esteem in beneficiaries than non-beneficiaries, which could be explained by the fact that beneficiaries are women living in extreme poverty, with lower education and income levels than the non-beneficiaries. Further, most of them come from an indigenous background so their answers could be biased by a Mayan cultural belief which dictates the man should be the head and authority of the household (Rubio Herrera, 2009).

In the case of Brazil, women, both beneficiaries (23 out of 30) and non-beneficiaries (26 out of 30) showed lower rates of feeling their opinion valued at home compared to women in Mexico. Beneficiaries showed low levels of feeling their opinion had the same weight as their husband's (10 out of 30), even lower than the beneficiaries in Mexico (16 out of 30). However, beneficiaries in Brazil had a higher rate of feeling that the wife's opinion had more weight than the husband's -11 out of 30, compared to 9 out of 30 who thought the husband's opinion had more weight. These results showed that while some women felt their husbands had more power, the rest of them felt their opinions had the same weight as their husbands' or even more. While in Mexico there is a clear inclination towards same weight or husband's opinion having more weight, in Brazil, the results are more balanced, and the answer in each category is almost a third.

This research showed that, paradoxically, it could happen that while women felt that their opinions were valued at home, they could also clearly feel that their husbands' opinion was more important than theirs. This belief seemed to be linked to the husband or partner being the main bread-winner in the household and to a traditional patriarchal gender hierarchy. This is exemplified by beneficiary B8 (52, 3 children) in Fortaleza, who stated: "Yes, my opinion is valued at home, he supports me on what I say." However, when asked about whether or not her opinion had the same weight as her husband's, her position changed radically: "No, my husband's 
[opinion] weighs more. I need to respect him, his "father authority," the woman must respect her husband."

In the case of non-beneficiaries, some of the responses showed the same pattern. While they felt their opinion was valued at home, they accepted their husbands' opinion as more important, as non-beneficiary B43 (53, 2 children) from Quixadá commented (after having said her opinion was valued at home): "His opinion is heavier, he always says that he can do what he wants because he's the man, the woman always stays lower." Other responses showed that women perceived their opinion valued at home, but because of patriarchal gender norms and a lack of financial resources they accepted their husbands' opinion as the most important, as nonbeneficiary B37 (31, 2 children) from Fortaleza explained: "His opinion has more weight, since he's the man and has more money."

\subsubsection{Personal Empowerment Awareness or Agency Consciousness}

Some beneficiaries showed the emergence of a process of "opening their eyes" regarding economic empowerment. We have termed the outcome of this process "personal empowerment awareness" or "agency consciousness." For example, beneficiary B12 in Quixadá (32, 6 children) went through an eye-opening process and reached empowerment awareness when she said that while answering the interview, she was realising that probably if she was financially independent, she could have more independence in general and her partner wouldn't be able to control her as much as he did then. She also mentioned that with more financial resources, she would probably have more decision-making power within her household.

Such an experience could be explained as a real gaining of agency - when women realise they could have more options and choices if their conditions were different. This process goes in line with what Kabeer (1999) mentions as suddenly being able to at least imagine the possibility of other circumstances, of choosing differently the emergence of a critical consciousness. It is an important process by which these women move from a position of unquestioning acceptance of the status quo, of the conditions of their lives, to having a critical perspective on it. From our sample, seven women expressed this awareness. This is around $5 \%$ of all interviewees. It is not a high number, but the fact that this process is starting to take place is very important. And this is one of the most valuable effects that programmes such as Oportunidades/Prospera and Bolsa Família can have.

The following section of this chapter analyses the effect that interviewees beneficiaries from Oportunidades and Bolsa Família perceive the programmes to 
be having on their lives. Beneficiaries in Campeche and Ceará were asked questions regarding:

1) attendance at educational talks ${ }^{58}$, whether they consider such talks useful talks, and things learnt from the talks,

2) change of habits as result of the talks, and general change of behaviour,

3) change in feelings of appreciation since receiving the transfers, and

4) other perceptions they would like to share.

\subsubsection{Beneficiaries' Perceptions of Educational Talks}

An important area in which CCTs contribute to women's empowerment is through the education that they receive in the educational talks. Although Oportunidades and Bolsa Família do not provide adult education such as literacy, beneficiaries do gain new knowledge and skills related to health and nutrition, among other topics. Oportunidades counts educational talks as a feature of the programme. Women are expected to attend monthly talks of approximately 60 minutes in which different topics are presented. Such topics focus on health, hygiene, nutrition, and sexual education, among others. The attendance at these talks is a co-responsibility (or conditionality) in order to receive the transfers, together with children's school attendance, and regular health check-ups.

During the field work, we asked beneficiaries about their attendance at the talks. All beneficiaries interviewed in Mexico said they attended the talks, which showed a perfect attendance rate.59 In Brazil, however, only six out of 30 reported attendance at talks. Most women said Bolsa Família did not provide talks in their communities.

In Mexico, when asked about whether or not they thought these talks were useful, 27 out of 30 women said yes. Beneficiary M4 (26, 3 children) from Campeche commented: "Yes,[it is useful] when there are talks, there are things you think you know, but you don't." It is relevant to mention that the women who said the programme talks were not relevant were women over 50. As beneficiary M8 (52, 3 grown-up children) from Campeche said: "The talks, I do not think the talks are useful for me, but it is the programme and I need to go. I think they are better for women with young children; they learn about nutrition and hygiene and how to feed the babies."

\footnotetext{
58 These educational talks take place every two weeks or every month. Beneficiaries must attend, as it is part of the co-responsibilities in order to receive the transfers.

${ }^{59}$ It should be kept in mind that attendance is a conditionality of the programme, so probably even if some women do not attend the talks all the time, they would respond positively for fear of being taken out of the programme; this is why I cannot be $100 \%$ sure that these answers were honest.
} 
When asked about the topics from the talks, beneficiaries mentioned a wide range of topics. The most frequent answers were:

1) care of children,

2) disease prevention (hygiene practices) and nutrition, and

3) maternal health and women's rights.

Table 6.2 Topics discussed in educational talks

\begin{tabular}{llc}
\hline Topics & Content & Frequency (N=60) \\
\hline Children's care & Feeding children with liquid salt solutions, & 17 \\
& how to prepare baby food and juice, \\
& communication with children (how to \\
& understand them, not to hit them, how to get \\
& close to them), children's hygiene (how to \\
bathe them, change diapers, wash hands) & \\
Hygiene/Disease & $\begin{array}{l}\text { Vaccinations, mosquito protection, boiling } \\
\text { prevention }\end{array}$ & $\begin{array}{l}\text { water, boiling vegetables, washing vegetables } \\
\text { and fruits using disinfectant, cooking foods }\end{array}$ \\
& $\begin{array}{l}\text { well, keeping foods covered from dust or } \\
\text { flies, washing hands, what to do in case of } \\
\text { pneumonia, digging holes to bury or burn }\end{array}$ & \\
garbage, AIDS protection, medicines, \\
diabetes care, clean house, clean backyard, \\
garbage disposal, clean land, wash dishes, \\
STDs awareness, remedies against fever, \\
dengue and diarrhoea, drugs/alcohol
\end{tabular}

*Women could provide as many topics as they wanted. Numbers may not total 60

Source: Author's own data

Table 6.2 provides the topics and content of educational talks as described by the beneficiaries. It is important to note that most of the information regarded children's care. In this area, most topics were related to 1) how to improve children's nutrition -how to prepare baby food and liquid salt solutions to prevent cholera, 2) children's hygiene -how to bathe them and change diapers, and 3) children's communication, with women learning how to bond with them, how to talk to them, not to hit them, etc. As we will see in the next section, the topic of 
communication with children was perceived as very important by the beneficiaries we interviewed. Another important area was hygiene habits and disease prevention and treatment, in addition to nutrition. Half of the beneficiaries mentioned they had learnt how to prevent and treat diseases, and how to prepare more nutritious foods. Maternal health and women's rights were the third most important topics, with one third of the beneficiaries mentioning they had learnt something regarding these topics. Also noteworthy is the fact that less than $10 \%$ of beneficiaries mentioned learning something about family planning and finances in the educational talks.

\subsubsection{Change of Habits and Change of Behaviour: Domestic Violence Awareness and Parenting Empowerment}

When asked specifically about which changes of habits or behaviours beneficiaries perceived as a result of the programme, most answers were in the following categories:

1) more economic independence from husband,

2) better hygiene and nutrition practices, and

3) better relation with children.

13 out of 60 women mentioned having more economic independence from their husbands because they received the transfers and attended the talks. They have also learnt money management and not to give their ATM cards and passwords to their husbands, as beneficiary M4 (26, 3 children) from Campeche told us: "Yes, I have changed my habits as a result of the talks. Now I do not give my bank PIN to my husband. They make you be independent, and they taught me to withdraw money slowly from ATMs."

In the area of hygiene-related practices, it is interesting to note that some things women learned in the programme could seem quite obvious to people from a better socio-economic background. For example, washing vegetables or putting a lid on food so the flies cannot get to it. However, the lack of education and awareness of these women was such that these small measures could mean the difference between life and death. For instance, children who previously would die of diarrhoea before turning 5 years old are now healthier and have better opportunities in life because of small changes in hygiene (Barber and Gertler, 2008). Further, they have access to better nutrition, as beneficiary M21 (60, 8 children) ${ }^{60}$ from Tenabo said: "You should wash your children's hands, give them vegetables. You learn what is bad for them, not to give them sodas [...]."

\footnotetext{
${ }^{60}$ While this beneficiary's children are adults, she is using what she learns in the educational talks to help raise her grandchildren.
} 
Nine out of 30 women mentioned that before the talks, they used to yell and hit their children and now, because of the talks on communication with children, they learned how to treat them better, communicate with them, get closer, and give them advice. This showed a process that we called "parenting empowerment." As beneficiary M26 (33, 3 children) from Tenabo said: "I was always yelling at my children. I have learnt to talk to my children, not insult them, not hit them, do not yell. Now I don't hit them anymore. I've learnt to live with them, to get close to them."

As can be seen from these quotes, women in these extreme poverty conditions do not know how to communicate with their children or with their husbands. In rural Mexico in particular, it was a traditional practice for parents to yell at and hit their children in order to "make them behave" and for husbands to hit their wives "just because." As a popular saying in the Mayan communities says: "When you come home from work, hit your woman. You don't know why, but she does," implying that women and children were second class human beings that can be treated with violence. This behaviour used to create a vicious cycle, were the husband would hit the wife in order to vent his frustrations, and then the wife would hit her children in order to vent her frustrations as well, creating thus a cycle of abuse.

Furthermore, this research suggested that the talks and the topics covered regarding women's rights and domestic violence set into motion a valuable process towards domestic violence awareness. Beneficiary M29 (43, 3 children) from Tenabo shared:

"When you listen to the talks, you realise no one should yell at you, you learn to defend yourself. Even if they don't hit you, they yell at you, and that is mistreatment, and your self-esteem starts going down, but you learn to defend yourself and you feel more relaxed, you yourself feel more valued."

This comment evidences a very important dual process: since the women attend the educational talks and learn about domestic violence, they learn how to defend themselves and how to be more assertive. At the same time, while learning about how to take care of their children and to communicate with them, they realise how to get close to them, how to talk to them without yelling or hitting them. This creates a dual process: women realise they deserve respect and freedom from violence and bad treatment (domestic violence awareness), and at the same time they learn to extend that right to their children (parenting empowerment) by treating them with respect, and without violence or yelling.

These domestic violence awareness and parenting empowerment processes can be overarched by the empowerment awareness or agency consciousness process that also takes place when women realise that if they had more economic independence 
they could have a better ability to make life decisions. These findings can be linked to Kabeer's (1999) empowerment framework in the following way:

\section{Figure 6.1 Effects of CCTs on beneficiaries' personal empowerment}

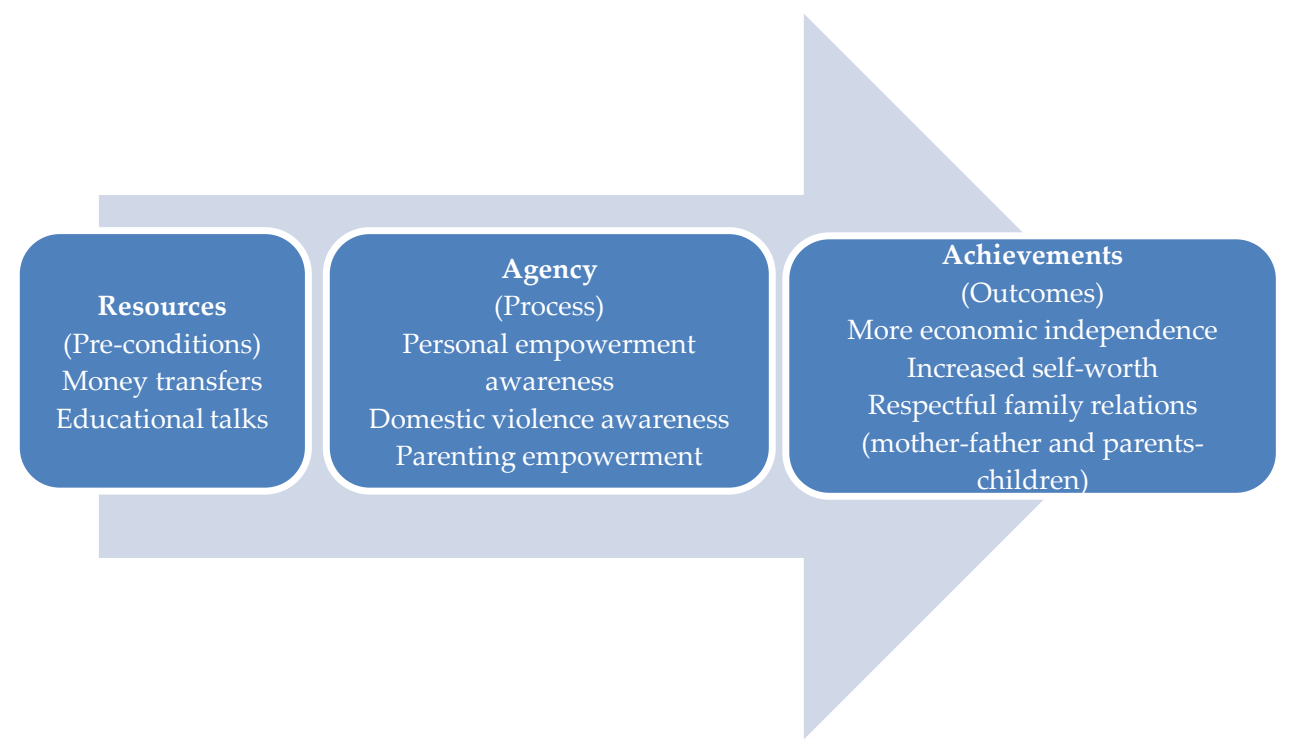

Source: Author's input in Kabeer's framework

The fact that these processes are taking place is a major finding of this research: This study suggests that to some extent, the CCT programmes indeed support or foster an empowerment process. Under certain conditions, such as economic transfers and educational talks, women can profit from the programmes and obtain the best benefits. These benefits are not only economic, but they can impact their whole lives by giving them a different outlook and understanding of their situation and how they can improve their conditions from a personal perspective.

Oportunidades and Bolsa Família have a gender approach, and although their objectives are mainly directed towards the children (better health, nutrition and education), the women beneficiaries (mothers) can also grow the seeds to a lifechanging process through the education provided by programmes. By receiving the money, and learning about how to use it (resource management), and learning about hygiene practices, women's rights and children's care, among others, beneficiary women can maximise the positive effect of the programme and become the agents of their own empowerment. 


\subsubsection{Increase in Respect since Receiving the Transfers}

When asked about whether participating in Oportunidades and Bolsa Família made interviewees feel differently about themselves, most respondents answered positively. In Mexico: three out of 10 in Campeche, five out of 10 in Hecelchakán, and six out of 10 in Tenabo; and in Brazil: six out of 10 in Fortaleza, seven out of 10 in Quixadá, and eight out of 10 in Mangue Seco, reported that they had new confidence and improved family and couple relationships. Beneficiary B25 (40, 6 children) from Mangue Seco told us: "I feel more relaxed, knowing I will have the income." Some comments suggested a greater awareness among women that they should be able to make their own purchasing decisions, as beneficiary B9 $(43,9$ children) from Fortaleza shared with us: "I feel more appreciation. If I have my money, I have more autonomy, I can buy what I want."

Some beneficiaries also mentioned that they felt recognised and supported by the state, and that they have a new-found self-respect when walking in the street and conducting their daily activities. They commented that they felt like they finally had a voice, which is also a component of the "personal empowerment awareness" process mentioned in the previous section. Their answers showed an increased sense of empowerment -what Rowlands (1998: 23) describes as a "sense of self in a wider context." This comment from beneficiary B20 (36, 7 children) in Quixadá provided an example: "Yes, [I feel more appreciation] in many ways. Before other people treated us disrespectfully, now not anymore." These findings are consistent with Escobar Latapí and Gonzalez de la Rocha's (2009) who found that women appeared to feel that their self-esteem and financial security was enhanced as a result of the transfers. Furthermore, they found that beneficiaries also reported feeling that they acquired more status in their neighbourhoods, with shopkeepers treating them with more respect as they became credit worthy.

While the Oportunidades/Prospera and Bolsa Família programmes have as their objective to improve the health and education of families in extreme poverty, they have also had an unexpected positive side-effect, which is to provide the beneficiaries with a new-found feeling of respect and self-worth not only in their homes, but in their public life in their communities.

\subsubsection{Other Perceptions}

\subsubsection{Cross-Country Differences in the Meaning of the Transfers}

An interesting point of this research is that there is a difference in the beneficiaries' perception of the transfers in Mexico and Brazil. Most women in Mexico reported that men largely supported women's role in the programme. Nonetheless, the 
majority of women in Brazil reported that they hid the money as they thought that if their husbands knew that they were receiving the transfers, they would stop contributing financially to the household. As beneficiary B12 (32, 6 children) in Quixadá said:

\begin{abstract}
"My husband does not know that I get the transfers. I hide them and buy what I need when the food is finished. For example, if there is no milk, I buy it with the Bolsa [Familia] money. If my husband sees it and asks [how I got it], I tell him is a gift from my sister or my mother. If he knew I'm getting this money, he would stop buying food and would tell me "now you have your money, so use it!" and he would go and buy cachaça [Brazilian alcohol]."
\end{abstract}

In Mexico, the situation is different. Women were open about getting the transfers, and the women said that the men seemed to feel better about it. Our findings from Mexico were consistent with Adato and Roopnaraine's (2010) and with Maldonado et al.'s studies (2006), which found that Oportunidades provided men with a source of support that lifted some pressure off of them. Men were not feeling threatened by the programme because it was viewed as providing money for children, not primarily for the mothers, even if the mothers controlled it. The Oportunidades' money was perceived as "children's money" and this imbued the money with a certain meaning, protecting it from men feeling threatened by it. As beneficiary B14 (36, 4 children) from Hecelchakán pointed out: "Sometimes my husband doesn't have a job, and he and my children are happy because they know that there's some money anyways. It's a way of supporting my home."

\title{
6.3.6.2 Aspirations for More Economic Opportunities
}

Interviewees' discussions consistently pointed towards skills that women would like to learn in order to engage in productive activities. This was revealing in terms of understanding women's aspirations and priorities and the types of government interventions that would fit them. Women spoke highly about Oportunidades and Bolsa Família and the benefits they brought to them in terms of extra money and health and educational improvements. However, they also spoke about wanting employment options in the labour market - income-generating options. Beneficiary B3 (48, 3 children) from Fortaleza pointed out: "I would like the programme to have more components, something to work, labour market insertion. So that we could increase our income beyond Bolsa [Família]."

Beneficiary B1 (39, 5 children) from Fortaleza also had many recommendations about what kind of workshops or activities the programme could provide: "Bolsa 
Família could include crack [awareness] projects, ${ }^{61}$ nutrition courses, sewing courses [to link to income-generating opportunities by selling clothes], and activities for children and the youth." These findings were consistent with Adato et al.'s (2000), who reported that beneficiaries appreciated the programme's education and training projects (including health and community leadership) when these were well-organised, but also wanted more access to education and training.

\subsubsection{A Desire for Men's Inclusion in the Programmes}

Another area of interest for beneficiaries was the participation of men in the programmes. Some women said that including men in Oportunidades' and Bolsa Família's meetings would be helpful so that when the women need to leave the house to participate in programme activities, the men would understand why, and also in order to change some of their macho behaviours. Beneficiary M29 (43, 3 children) from Tenabo told us her reflexions regarding recommendations for the programme:

"I think it would be good to extend the talks to women and men. Men think that being men they can do what they want. There's a vicious cycle of machismo and alcoholism. Men should also learn what we women learn. Sons copy the attitudes and behaviours of their fathers, therefore men should have explained to them what machismo is, so they know they shouldn't go around having children everywhere, so they have an educated sexuality, and so that they don't mistreat women."

Men's education would be another way to improve the adult education dimension of Oportunidades and Bolsa Família. As Adato and Roopnaraine (2010) point out, men's attitudes towards women and girls, and towards education and health, affect the extent to which women are able to profit from the benefits that CCTs offer. For example, whether women can keep the money of the transfers and decide how to spend it, whether girls can go to school, and whether women can use the health services offered or implement what they learn in the health talks -such as cervical cancer tests and family planning.

Many women suggested that men are "abandoned" by the programmes and that they should also attend some talks, especially regarding issues that affect how men

\footnotetext{
${ }^{61}$ In Brazil, especially in Ceará, there is a problem of crack consumption, particularly among the poor and the young. Brazil has the biggest crack epidemic in the world, surpassing the United States (http://edition.cnn.com/2014/05/09/world/americas/brazil-crack-cocaine-world-cup/). The government has some awareness programmes in place, and Ceará counts with Psycho-Social Attention Centres for Alcohol and Drugs (Centros de Atencao Psicossocial Álcool e Drogas -CAPS) which are open 24 hours and are free of charge.
} 
behave in the household. Training ideas included how to treat women and the family, prevention of domestic violence, education for couples, and the importance of health care for the entire family, including men.

\subsection{Concluding Remarks}

This chapter focused on the feelings of self-worth and women's perceptions of personal empowerment in Campeche and Ceará, and on the effect that Oportunidades and Bolsa Família can have on these areas by providing beneficiaries with more economic resources (cash transfers) and educational talks. The findings were divided in three categories: a) beneficiaries' and nonbeneficiaries' own perceptions of self-worth and empowerment, b) Oportunidades' and Bolsa Família's effects on the beneficiaries' lives, c) beneficiaries' opinions regarding the programmes.

The main finding in the first category was that while most women felt their opinions were valued at home, they also felt that their husbands' opinions had more weight. This was based on traditional patriarchal hierarchies and on the women's lack of financial resources. In the second category, the findings suggested that CCT receipt and educational talks' attendance are creating a process of "personal empowerment awareness," where women realised that if they were financially independent (or at least had more financial resources), they could have more independence in general and they could have more decision-making power within their households. Such an experience could be explained as a potential gaining of agency, when women realise they could have more options and choices if their conditions were different. This process goes in line with what Kabeer (1999) mentions as suddenly being able to at least imagine the possibility of other circumstances, of choosing differently -the emergence of a critical consciousness. Furthermore, the attendance to educational talks helped to create a dual process of domestic violence awareness and parenting empowerment.

The fact that these processes are taking place is a major finding of this research. It suggests that to some extent, the CCT programmes are indeed supporting or fostering an empowerment process. Under certain conditions, such as economic transfers and educational talks, women can profit from the programmes and obtain salient benefits. These benefits are not only economic, but they can impact women's entire lives by giving them a different outlook and understanding of their situation and how they can improve their conditions from a personal perspective.

In the third category, the findings related to the ideas beneficiaries have regarding the programme. Mainly, beneficiaries would like the programmes to include more access to education and to income-generating opportunities, and the inclusion of 
men's participation in the programmes' activities. Beneficiaries suggested that including men in the programmes' objectives could improve the extent to which women and the whole family are able to profit from the participation in the CCTs. Other important topic that emerged from this study was that some beneficiaries mentioned that they now felt recognised and supported by the state, and that they had a new-found self-respect when walking in the street and conducting their daily activities.

As it was shown, there are perceptible changes in the way women see themselves and certain conditions in their lives, and these changes have the potential to translate into other forms of empowerment. In conclusion, Oportunidades/ Prospera and Bolsa Família have an effect on the beneficiaries' perceptions of selfworth and empowerment. However, empowerment is context-specific, and in the case of Mexico, where women have access to educational talks, this effect appears to be greater. If the transfers come with knowledge -human capital investment, the personal empowerment level rises more than in a context where the transfers are given without information. 


\section{Chapter 7. Conclusions, Policy Implications and Suggestions for Future Research}

\subsection{Restatement of Research}

The objective of this research was to examine women's perceptions of the consequences of CCTs on their empowerment and to assess what the conditions are that would need to be in place for CCTs to have an empowering effect on women beneficiaries who live in extreme poverty. For the purpose of this study, empowerment was defined as the process by which people who have previously been denied or have not had the opportunity and the ability to make choices acquire such an ability. This opportunity is especially important in strategic areas, such as livelihood, civil status, or maternity decisions (see Kabeer, 1999). Using the Oportunidades/ Prospera programme in Mexico and the Bolsa Família programme in Brazil as case studies, this study examined which cultural, social and policy conditions are in place for the empowerment process to happen in different areas of women's lives, including labour market participation, intra-household decisionmaking, and feelings of self-worth and personal empowerment. We focused on the role that CCTs play in women's empowerment in these areas.

Since the objective of this research was to analyse the experiences of women interviewees and the mechanisms by which empowerment occurs, and specifically how the women interviewed perceived their empowerment to be fostered through conditional cash transfers, we employed a case study approach using qualitative methods. We obtained the data for this study through semi-structured in-depth interviews conducted with beneficiaries and non-beneficiaries from Campeche in Mexico and Ceará in Brazil in 2012, where we carried out field work for a total of six months. The participants consisted of ten women beneficiaries and ten women non-beneficiaries living in extreme poverty in three different communities (rural, semi-urban, and urban) in both countries. In total, we interviewed 120 study participants whose ages ranged from 15 to 60 years.

\subsection{Main Findings}

In general, our findings suggested that CCTs do have some empowering effect, or the potential to have an empowering effect; nonetheless, this effect is stronger in some areas than in others. As Box 7.1 shows, in the area of labour market participation, the CCTs had a two-fold effect on the study participants in our sample: they substituted income, by allowing beneficiaries to have resources and invest their time in childcare instead of participating in the labour market, and they 
had an employment trigger-effect -some beneficiaries started to work after receiving the transfers since they realised they had few resources and wanted to have more income. In the area of intra-household decision-making, CCTs had a lower empowerment effect due to the persistence of traditional gender norms. However, the bigger effect was in the areas of food expenditure and decisionmaking regarding children. Finally, in the area of personal empowerment, CCTs contributed to some empowerment processes, which we defined as personal empowerment awareness, domestic violence awareness and parenting empowerment and will discuss in more detail below.

\section{Box 7.1 CCTs' main effects by area of empowerment}

\begin{tabular}{|ll|}
\hline Area of empowerment & Effects \\
Intra-household & CCTs had a two-fold effect: \\
decision-making & $>$ Substitute income \\
& - CCTs had low effect due to persistence of traditional \\
& (patriarchal) gender norms. \\
& - Most effect in the areas of food expenditure and \\
& decision-making related to children. \\
& - Less effect on ability to choose friends, reproductive \\
health (especially in Brazil), and freedom of mobility to & meet male friends and relatives. \\
Personal empowerment & CCTs contributed to the following processes, through \\
& $>$ Pash transfers and educational talks: \\
& $>$ Personal empowerment awareness \\
& $>$ Parenting empowerment
\end{tabular}

Source: Author's own findings

Furthermore, other main findings of this research suggested that women have rich views and understandings of their situation as Box 7.2 illustrates. Most women in our sample perceived work as a source of pride and had strong motivations to work. After receiving the CCTs, some beneficiaries felt more recognised and supported by the state, and they had a newly-found self-respect when walking in the street and conducting their daily activities. Nonetheless, this study showed that CCTs have limits to their potential for an empowering effect. There were structural and individual barriers that mediated the CCT effect on women's empowerment (see Figure 7.1). In addition, empowerment was mostly context-specific. The structural barriers related mostly to patriarchal gender norms that hindered women's individual empowerment. The individual barriers related especially to women's lack of education and skills -in short, their lack of human capital. Our findings showed that many women were strongly motivated to work, but that they 
perceived and experienced three main barriers: 1) lack of child care, 2) lack of education, and 3) old age (i.e. lack of energy and employer discrimination towards older women).

\section{Box 7.2 Other main findings}

\begin{tabular}{|c|c|}
\hline Research area & Other main findings \\
\hline Labour market participation & $\begin{array}{l}\text { - Most women saw work as a source of pride. } \\
\text { - Motivations to work: } \\
>\text { To earn their own money to achieve } \\
\text { independence from partner/spouse. } \\
>\text { To be able to buy and save more. } \\
>\text { To give their children a better life. }\end{array}$ \\
\hline $\begin{array}{l}\text { Intra-household } \\
\text { decision-making }\end{array}$ & $\begin{array}{l}\text { - Orchestration of power. } \\
\text { - In Mexico women expressed making mostly jointed } \\
\text { decisions, while in Brazil the decisions were mostly made } \\
\text { by either the wife or the husband. } \\
\text { - Three kind of scenarios related to wives' economic and } \\
\text { educational status: } \\
>\text { In households where the women had more } \\
\text { education or where husbands worked further } \\
\text { away, women managed to make more decisions } \\
\text { on their own. } \\
>\text { In households where both women and men had } \\
\text { the same education or economic level, most } \\
\text { decisions were made together. } \\
>\text { In households where women had a lower } \\
\text { education level, men seemed to make most } \\
\text { decisions on their own. }\end{array}$ \\
\hline Personal empowerment & $\begin{array}{l}\text { - While most women felt that their opinions were valued at } \\
\text { home, they also felt that their husbands' opinions had } \\
\text { more weight (due to traditional patriarchal hierarchies and } \\
\text { to the women's lack of financial resources). } \\
\text { - Some beneficiaries now felt recognised and supported by } \\
\text { the state, and they had a newly-found self-respect when } \\
\text { walking in the street and conducting their daily activities. }\end{array}$ \\
\hline $\begin{array}{l}\text { Perceptions of } \\
\text { Oportunidades and } \\
\text { Bolsa Família }\end{array}$ & $\begin{array}{l}\text { - Beneficiaries would like the programmes to include: } \\
>\text { More access to education. } \\
>\text { Income-generating opportunities. } \\
>\text { Men in the programmes' activities. }\end{array}$ \\
\hline
\end{tabular}

Source: Author's own findings

In addition, the findings evidenced the persistence of traditional gender norms that disempower women in intra-household decision-making, especially women who lack formal education, despite CCT receipt. The findings also showed that the 
context in which women live (urban vs. rural community) matters to the effect CCTs have on women's empowerment.

\section{Figure 7.1 Barriers to women's empowerment}

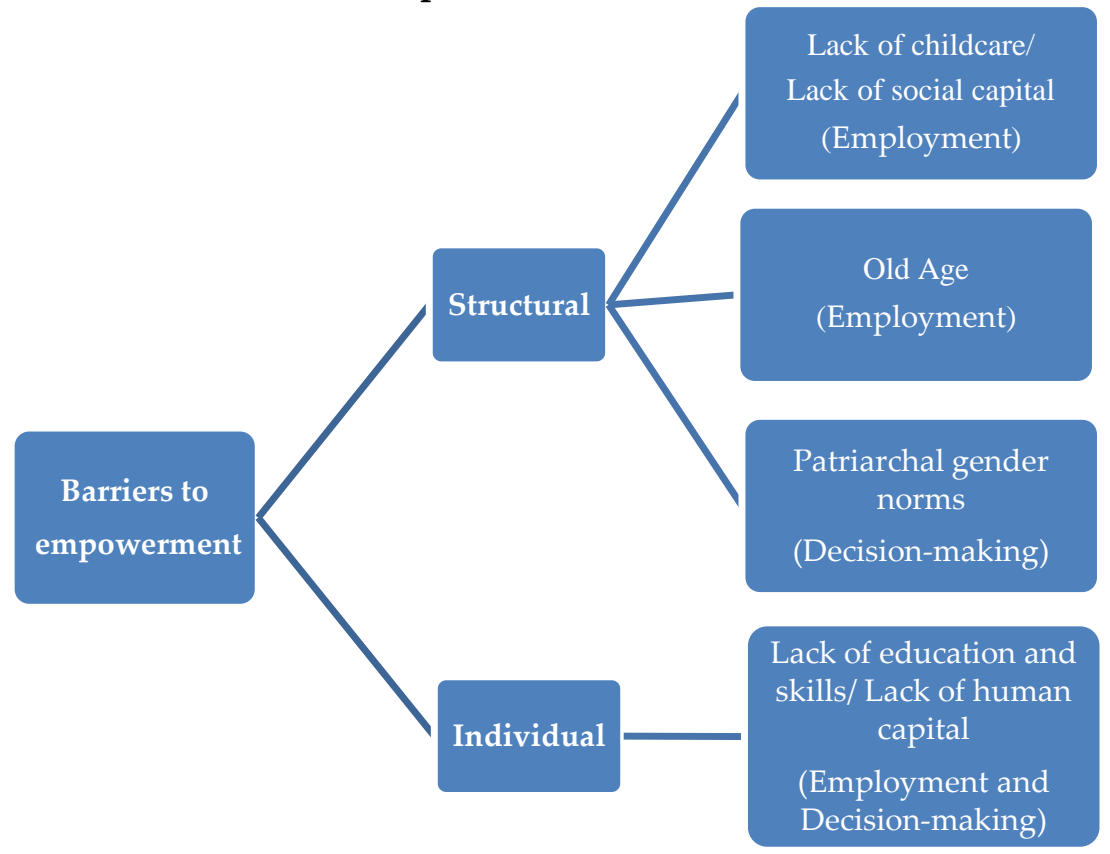

Source: Author's own findings

In the following sections, we will discuss in what ways our findings contribute to the existing literature on the empowerment effects of CCTs on women living in extreme poverty before presenting policy implications and suggestions for future research.

\subsubsection{CCTs and the Labour Market}

There is a large body of quantitative research about the impact of CCTs on labour market participation (see Oliveira, 2005; Maluccio, 2007; Attanasio et al., 2008; Foguel and Barros, 2008; Skoufias and Di Maro, 2008; Alzúa et al., 2009; Angelucci and Di Giorgi, 2009; Tavares, 2010; Teixeira, 2010; and Novella et al., 2012, among others). However, no qualitative research has been undertaken to find out the motivations behind women's choices regarding labour market participation. Chapter 4 attempted to fill this knowledge gap.

The overall design of CCTs is not directly related to adult employment in beneficiary households. There are no work requirements or restrictions, and households can earn labour income without losing the benefit. Nonetheless, as 
Alzúa et al. (2009) point out, this lack of work requirements does not mean that the programmes are neutral in terms of adult labour supply and participation incentives. Since CCTs modify the income of the household and, possibly, the allocation of time through their impact on children's work and school enrollment, there is potential for effects on adults' labour supply in beneficiary households.

However, most of the existing literature on the effects of CCTs has focused on educational performance, health and nutritional outcomes of children (see, for example, Behrman et al., 2004; Veras Soares et al., 2010). Less attention has been paid to the indirect effects that cash transfers could have on adults' behavior, especially regarding the effects of CCTs on adult labour supply. Criticism suggests that while cash transfers are necessary to accomplish improvements in consumption, education, and health, they can also generate incentives to reduce work supply among adults, since this payment can be thought of as a pure income effect (Fernandez and Saldarriaga, 2014). Nonetheless, experimental evidence has shown small effects of CCTs on labour supply of adults from beneficiary households (Parker and Skoufias, 2000).

Parker and Skoufias (2000) show evidence that mothers in Oportunidades increased the time allocation for childcare, while Skoufias (2006) discusses quantitative and qualitative evidence showing that Oportunidades is associated with more participation of women in the household decision-making process, with a positive change of men's attitudes toward women, and with an increase in women's empowerment. Novella et al. (2012) find that as bargaining power in the household becomes more balanced or shifts toward women, the labour supply of mothers seems to increase. Further, they show that women are more likely to be employed when they have more bargaining power in the household. These findings might suggest that more powerful mothers are able to overcome traditional gender roles and supply more labour.

In general, the findings based on our sample indicate that both programmes did not have a major effect on the labour market participation of the women and did not introduce any substantial disincentives to work. These results are consistent with those of Alzúa et al. (2013). The finding that monetary transfers have not had an effect on employment is compatible with a setting in which income effects are either small or counterbalanced by some other factors (assuming that leisure is a normal good for beneficiaries). Nonetheless, there is a two-fold effect of CCTs: an income substitute and an employment trigger-effect. Some women stopped working after receiving the transfers to take care of their children. Other women started to work after receiving the transfers, since they realised they had only a small family income and wanted to improve their economic situation. 
When looking at the findings, it is important to keep in mind the profile of the interviewees: they were female heads of households living in extreme poverty, with few years of education and in some cases, no education at all. Between $50 \%$ and $66 \%$ of them worked, but mostly part-time and in low-remuneration and lowskilled jobs, such as domestic workers, cleaning services, doing laundry, etc. Most of them had between three and five children (and in some cases between seven and ten), many times from different husbands/partners, and they relied on their husbands'/partners' income to take care of their children. In many cases, the husband was physically aggressive (especially in Mexico), and in other cases they were drug users (especially in Brazil). Due to this situation, women sometimes felt trapped by their life circumstances and wished they could have access to incomegenerating activities, but without neglecting their children's care.

Furthermore, complex and nuanced patterns of responses emerged from both Oportunidades' and Bolsa Família's beneficiaries. Most of the study participants mentioned that work in itself was a source of pride. Participating in the labour market and having the capacity to earn their own income made recipients feel more valuable as a person and in their households. In addition, they felt they had more options and choices in their lives (i.e. leaving their husband, saving, investing in a productive activity). This situation influenced their self-esteem and their perceived life satisfaction in a positive way. As their motivation, we found that, mainly, women were driven by the desire to make their own money (to have more income to spend or save), to be financially independent from their partners, and to give a better life to their children. Beneficiaries complied with the CCTs conditionalities because they wanted to give their children better health, education, and future productive opportunities.

This study showed that beneficiaries in Mexico showed a higher labour participation rate than non-beneficiaries, but in Brazil, this figure was reversednon-beneficiaries of Bolsa Família had a higher participation rate than beneficiaries. Another interesting finding from our data is that in Mexico, no working women, whether beneficiary or non-beneficiary, had a full time job. However, in Brazil, around a third of the beneficiaries and non-beneficiaries were working full time. In addition, in Mexico, three quarters of beneficiary working women were participating in the formal labour market, while only one quarter of non-beneficiaries were part of the formal labour market. These results suggest that beneficiary women preferred the security of a formal job due to their lack of resources otherwise, while non-beneficiaries preferred to be self-employed informally and provide goods or services in their own free time. In Brazil the same trend was observed. 
Regarding the decision to stop working, none of the non-working beneficiaries mentioned receiving Oportunidades as a reason to stop working once they received the transfers, differing from criticism suggesting that CCTs can provide incentives to reduce labour (Pedrozo, 2010). The common narrative of the nonbeneficiaries who stopped working was that they enjoyed working, but now they needed to take care of their children. A key finding of this research is that the main barriers to work for both beneficiaries and non-beneficiaries, in both countries, are lack of child care (social capital), lack of education and human capital, and old age. This differs from criticism that states that women will stop working as a consequence of the CCTs transfers (see Fernandez and Saldarriaga, 2014). It is in the context of their individual and social barriers that women beneficiaries stop working.

It is also noteworthy that both in Mexico and in Brazil, a percentage of beneficiary women participating in the labour market did not used to work before receiving the transfers and only started working after earning that extra income, showing an employment trigger-effect of the CCTs. In Mexico, 20\% of working beneficiaries in our sample started to work after getting the transfers, and in Brazil 35\% of working beneficiaries in our sample started to participate in the labour market after receiving Bolsa Família. These findings are consistent with Tavares (2010), who found evidence that mothers receiving Bolsa Família showed a 5.6\% probability of participating in the labour market. For these beneficiaries, receiving the transfers started a process of wanting to improve their economic and personal situations.

Our findings, however, were nuanced. In Mexico, no beneficiaries stated that they stopped working after receiving the transfers because of having more income. In Brazil, nonetheless, three beneficiaries said they stopped working due to their increased resources, showing an income substitute of CCTs. These answers are consistent with the findings of Pedrozo (2010), who found that the Bolsa Família programme led to a negative effect on adults' labour supply.

This shows that there is indeed ambiguity in the results and that numbers and percentages of wider studies need to be taken with a grain of salt, since normally the decision to stop working is not a straight-forward consequence of increased income, but has to do with other individual and structural factors, such as health problems, old age, and childcare. This decision could also be perceived as an increase in welfare, which is a positive outcome. 


\subsubsection{CCTs and Intra-Household Decision-Making}

Oportunidades and Bolsa Família designate women as transfer recipients in order to compensate mothers for their traditional domestic and care work role, to ensure that programme co-responsibilities are met and in recognition of the fact that they are most likely to ensure that increased household income benefits children. Transferring cash to women is also seen as a way to promote their control over household resources and increase their bargaining power at home (Holmes et al., 2010). However, transferring cash to women does not necessarily imply that women's control over household resources increases. Given the growing popularity of such programmes and widespread interest in increasing women's empowerment, it is important to assess whether resource transfers to women through these programmes are in fact effective in improving women's decisionmaking positions within the household. While some qualitative studies suggest that CCTs with female beneficiaries increase women's decision-making power on certain issues within the household (Adato and Roopnaraine, 2010), evidence of this effect in the context of CCTs is both limited and mixed. In chapter 5, we provided more in-depth knowledge in this area by presenting qualitative evidence on the effect of Oportunidades/Prospera and Bolsa Família on women's intrahousehold decision making.

In chapter 5 of this study, we analysed decision-making in five areas: 1) economic, examined by household expenditure, 2) familial, measured by decisions regarding children's issues, 3) personal, measured by ability to choose occupation, activities, and friendships, 4) reproductive, analysed by looking at women's ability to use contraception, have control over sexual relations, child-bearing, and attendance at health check-ups, and 5) socio-cultural, analysed by women's freedom of mobility. The findings suggested a very traditional gendered division of spending: we found a highly gendered decision-making process by which women were more likely to decide on food expenditure, personal items and expenditures on children, and less likely to decide about durable goods or house repairs. These results are consistent with the theory of "orchestration power" by Wolley and Marshall (1994). Men seem to have more power to make the "important" decisions, while women make the "unimportant" and time-consuming decisions such as deciding what to buy for food or making decisions related to children.

The findings in the area of economic decision-making suggested that women can mostly decide how to spend the money in the following order: 1) food expenditure, 2) personal expenditure, 3) expenditure for children, 4) durable goods, and 5) savings. 
In the food expenditure area, almost all beneficiaries and non-beneficiaries from Oportunidades could spend money without asking their husbands. The difference among beneficiaries and non-beneficiaries was very small, suggesting that receiving the transfers did not create a big effect on it and that women have been traditionally the ones who have made the decisions regarding food expenditure. In the case of Brazil, almost $90 \%$ of beneficiaries and non-beneficiaries from Bolsa Família also could make food purchasing decisions. These findings are in line with Adato and Roopnaraine's (2010) research, which points out that women make most decisions about small household expenditures, particularly food purchases. They also found little difference in the comments of beneficiaries and non-beneficiaries, suggesting that this hierarchy of intra-household decision-making preceded participation in the CCTs. Handa et al. (2009) also suggest that the transfers do not significantly change spending behaviour.

Regarding the attitudes towards the CCT money, the field work revealed that in Mexico, the women beneficiaries in our sample were open about receiving the money, and men accepted it as "children's money" and did not perceive it as a threat. This finding is consistent with Maldonado et al. (2006), who suggest that men view the money specifically for the children's well-being and was not perceived as a cause of conflict. In Mexico, husbands were aware of the women receiving the money and perceived it as an extra help for their children, money which should be canalised towards their children's nutrition and education. This perception was positive, and women reported feeling more valued and appreciated in their households as they now contributed to the general budget. In contrast to Mexico, our findings showed that beneficiaries in Brazil hid the money of Bolsa Família to buy things for the house when they ran out. A large number of Bolsa Família beneficiaries mentioned that they did not tell their husbands they were getting the governmental help, since they were afraid their husbands/ partners would stop providing for the family.

This study showed that both beneficiaries and non-beneficiaries in Mexico and Brazil had a high decision-making power when it came to children's issues. Decisions in all areas of children's lives were mostly taken by the mothers. This showed a highly gendered decision-making process in the households. It is interesting to note that in both Mexico and Brazil beneficiaries seemed to be less able to make decisions regarding personal decisions than non-beneficiaries. In Ceará, our research suggested that there is empowerment related to decisions within the household, but not outside. Women were able to make most decisions regarding the needs of the household (i.e. food expenditure, what to cook, children's permissions, etc.) but were not able to go outside freely, decide to participate in activities and choose their own friends, particularly male friends. 
Our findings suggested that women were not going out of the house if their husbands did not allow them so they could keep the domestic peace.

The findings showed that in Mexico, $77 \%$ of beneficiaries reported using contraception, while $93 \%$ of non-beneficiaries used contraception. $87 \%$ of beneficiaries reported having control over sexual relations, while $97 \%$ of nonbeneficiaries said they could decide whether or not they wanted to have sexual relations. $87 \%$ of beneficiaries reported having control over child-bearing decisions (whether or not to have a baby and when to have it), while $93 \%$ of nonbeneficiaries reported being able to make this decision. Finally, $90 \%$ of beneficiaries and all non-beneficiaries reported that they attended periodic health check-ups. It is noteworthy that in Mexico, non-beneficiaries reported higher levels than beneficiaries of decision-making in all four areas of reproductive health issues. This could be due to the low socio-economic level of the beneficiaries and their lack of education regarding reproductive health. In this case, even if the Oportunidades programme provided educational talks and had the conditionality of attending health check-ups, non-beneficiaries seemed to enjoy a higher decision-making level.

In the case of Brazil, this pattern continued for the areas of contraception use and control over sexual relations: non-beneficiaries reported more contraception use and more control over sexual relations than beneficiaries. These results differed from the findings on contraception of De Brauw et al. (2014), who found that beneficiaries had a higher decision-making power in the area of contraception than non-beneficiaries. However, our findings suggested that women (both beneficiaries and non-beneficiaries) in urban areas enjoyed more decision-making power in the area of contraception than women in semi-rural and rural areas. This finding is in line with the results of De Brauw et al. (2014), who found that in urban areas the effects on contraception are larger and more highly significant than in their aggregate estimates.

Our findings suggest that in the area of reproductive health, women in Mexico (both beneficiaries and non-beneficiaries) seemed to have more decision-making power than in Brazil. This could be explained by a higher access to education in Mexico, where emphasis was put on health education. Further, access to education talks for women beneficiaries could be having the added benefit of making them aware of their rights, since one of the topics covered in the talks is reproductive health. Mobility is one of the areas with the least empowerment: many women both in Mexico and Brazil could not meet single female friends and male friends and relatives. 
This research showed that in Mexico, most of beneficiaries and non-beneficiaries reported making most decisions jointly. This finding is in line with Gómez de León and Parker's (1999) research, which found that there is an apparent "jointness" of decision-making in Mexico, with the dominant response being that decisions are taken jointly by husband and wife. However, our findings suggested that there was a highly gendered decision-making process, where typically women were in charge of "domestic" areas, such as nutrition, health, education, clothing, children's issues, and daily household decisions; while men were in charge of "bigger" decisions, such as home repairs, durable purchases, cars, or travels, and also of mobility permissions for wives/partners and children.

In the end, there were three kind of scenarios according to the wives' or partners' economic and educational status. In households where the women had more education or where husbands worked further away, women managed to make more decisions on their own. In households where both women and men possessed the same education or economic level, most decisions were made together. And finally, in households where women had a lower education level than men, men seemed to be able to make most decisions on their own.

The heterogeneity of our results seems to show that empowerment is culturespecific and it can be dependent on education levels. Women from a background with lower educational attainment are less likely to make their own decisions; conversely, women with higher education levels seemed to make more decisions on their own. In addition, cultural and social capital matter, and there is still a predominance of traditional patriarchal norms. In Mexico, women seemed to experience more empowerment both within and outside of the household. In Brazil, it seemed that there was empowerment within the household, but not outside. Women stated that they made more decisions about money and home issues, but they could not go outside without permission to keep the domestic peace. However, women in Brazil felt that their opinion had the same weight as their husbands', or even more weight. But for the outside, the opinion of the husband needed to appear stronger.

\subsubsection{CCTs and Women's Experiences of Empowerment}

Chapter 6 focused on the effect that Oportunidades and Bolsa Família had on the beneficiaries' personal empowerment and feelings of self-worth. The findings demonstrated that in Mexico most women, both beneficiaries and nonbeneficiaries, had a high number of positive answers when asked about whether or not they felt their opinion was valued at home. Nevertheless, it is interesting to note that in the case of beneficiaries, it seemed that only around half of the interviewees felt their opinion had the same weight as their husband's opinion. So, 
while they felt mostly valued, they also thought that their husband's opinion had more weight than theirs. This related to the prevalence of traditional patriarchal norms and also to women's lack of financial resources.

Another important finding was that women in Mexico seemed to relate having their opinion valued at home with their children respecting and obeying them. One third of the interviewees mentioned that their children obeyed them as part of their feelings of value. Thus their feelings of value within the household still appeared to be linked to their maternal role and acceptance of their authority by their children. It is noteworthy that non-beneficiaries showed higher rates of their opinion having the same weight as their husbands than beneficiaries; and one-sixth of non-beneficiaries considered their opinion more important than their husbands', compared to only one beneficiary. These results could be interpreted as lower empowerment or lower self-esteem among beneficiaries than non-beneficiaries, which could be explained by the fact that beneficiaries are women living in extreme poverty, with lower education and economic levels than the nonbeneficiaries.

In the case of Brazil, both beneficiaries and non-beneficiaries showed lower rates of feeling their opinion valued at home compared to the women in Mexico. Beneficiaries showed low levels of feeling their opinion had the same weight as their husbands' (10 out of 30 in the Brazilian sample), even lower than the beneficiaries in Mexico (16 out of 30). However, beneficiary participants in Brazil exhibited a higher rate of feeling that the wife's opinion had more weight than the husband's (11 out of 30), compared to nine out of 30 who thought the husband's opinion had more weight. These results showed that while some women felt their husbands had more power, the rest of them felt they had the same weight or even more. While in Mexico there was a clear inclination towards same weight or husband's opinion having more weight, in Brazil, the results were more balanced, and the answer in each category was almost a third.

A key finding of this study is that some beneficiaries experienced a process of "opening their eyes" regarding economic empowerment. We called this process "personal empowerment awareness" or "agency consciousness." Through this process, some beneficiaries realised that with more financial resources they would probably have more independence and more decision-making power within their households. Such an experience could be explained as a real gaining of agency, when women realise they could have more options and choices if their conditions were different. This process goes in line with what Kabeer (1999) mentioned as individuals suddenly being able to at least imagine the possibility of other circumstances, of choosing differently, or experiencing the emergence of a critical consciousness. It is an important process by which some women move from a 
position of unquestioning acceptance of the status quo, of the conditions of their lives, to having a critical perspective on it. And this is one of the most valuable effects that programmes such as Oportunidades and Bolsa Família can have.

Another important area in which CCTs contribute to women's empowerment is through the education that they provide with the help of the educational talks that are part and parcel of the programmes. Although Oportunidades/Prospera and Bolsa Família do not provide adult education such as literacy, beneficiaries in our sample did gain new knowledge and skills related to health and nutrition, among others. Oportunidades/Prospera considers educational talks as a feature of the programme. Women are expected to attend monthly talks in which different topics are presented. Such topics focus on health, hygiene, nutrition, and sexual education, among others. The attendance at these talks is a conditionality so women can receive the transfers, together with children's school attendance, and regular health check-ups.

We found that through the CCT receipt and the educational talks, women experience what we have called "domestic violence awareness" and a "parenting empowerment process." Women mentioned that before attending the talks, they used to yell and hit their children; now, because of the talks on communication with children, they learned how to treat them with respect, communicate with them, grow closer, and give them advice. This indicates an important process of "parenting empowerment." This research also suggests that due to these talks and the topics on women's rights and domestic violence, a valuable process of "domestic violence awareness" has begun. Since the women attended the educational talks and learned about domestic violence, they learned how to defend themselves and how to be more assertive. At the same time, while learning about how to take care of their children and to communicate with them, women realised how to get close to them and how to talk with them without yelling or hitting them. This created a dual process: women realised that they deserved respect and freedom from violence and bad treatment themselves (domestic violence awareness), and at the same time they learned to extend that right to their children (parenting empowerment) by treating them with respect, and without violence or yelling.

These domestic violence awareness and parenting empowerment processes can be overarched by the personal empowerment awareness or agency consciousness process that also takes place when women realised that if they had more economic independence they could have a better ability to make their own or influence life decisions. Figure 7.2 illustrates these links between CCT-related resources, women's agency and achievements. 


\section{Figure 7.2 Enhanced empowerment framework}

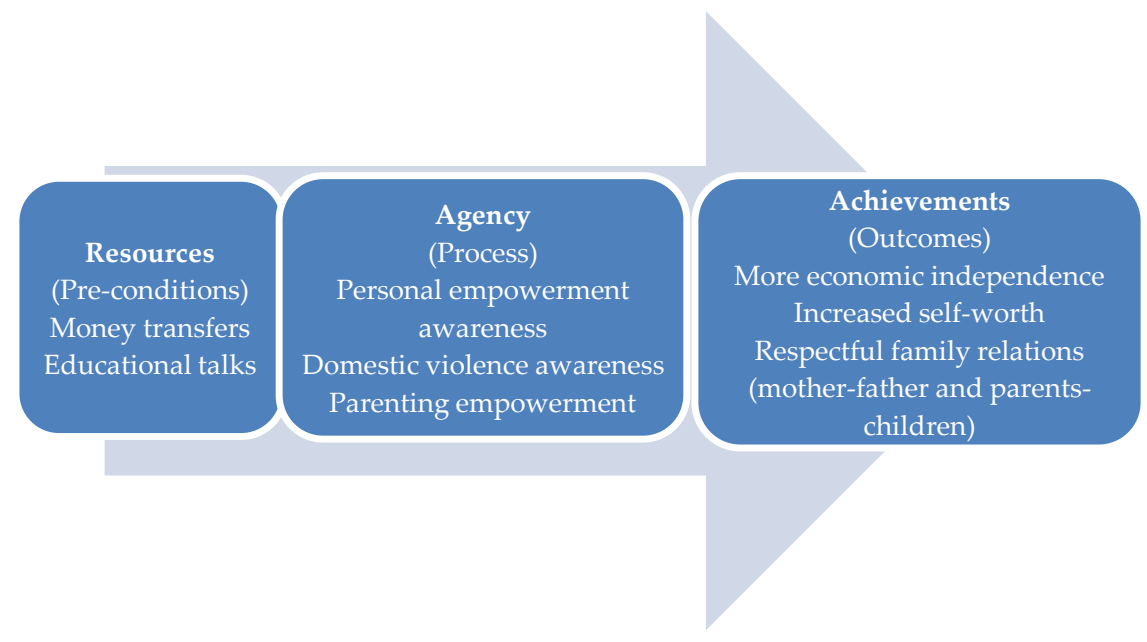

Source: Author's application of Kabeer's framework to CCTs based on author's own research

The fact that these processes took place as a result of CCTs is a major finding of this research. It suggests that to some extent, the CCT programmes are indeed fostering an empowerment process. Under certain conditions, such as economic transfers and educational talks, women can profit from the programmes and obtain empowerment-related benefits. These benefits are not only economic, but they can impact their whole lives by giving them a different outlook and understanding of their situation and how they can improve their conditions from a personal perspective.

Oportunidades and Bolsa Família embrace a gendered approach, and although their objectives are mainly directed towards the children in a family (better health, nutrition, and education), the women beneficiaries (mothers) can also obtain the seed to a life-changing process through the programmes. This research suggests that by receiving the money, and learning about how to use it (resource management), hygiene practices, women's rights, and children's care, among others, women recipients of CCTs can maximise the positive effect of the programme and be the agents of their own empowerment.

Furthermore, some beneficiaries also mentioned that they felt recognised and supported by the state, and that they have a new-found self-respect when walking in the street and conducting their daily activities. They commented that they felt like they finally had a voice, which is also a component of the "personal empowerment awareness" process. Their answers showed an increased sense of 
empowerment, what Rowlands (1998:23) describes as a "sense of self in a wider context."

As it has been shown, there are perceptible changes in the way women in our sample perceived themselves and certain conditions in their lives, and these changes had the potential to translate into other forms of empowerment. As Kabeer points out, even if changes in empowerment are small, they are a start, since "the availability of alternatives at the discursive level, of being able to at least imagine the possibility of having chosen differently, is thus crucial to the emergence of a critical consciousness, the process by which people move from a position of unquestioning acceptance of the social order to a critical perspective on it" (Kabeer, 1999: 441).

\subsection{Policy Implications}

Some critics of CCTs (see, for example, Bradshaw, 2008) state that although the enhancement of women's skills is positive, providing training in health and nutrition is also instrumental to the programme's success and thus does little to build women's empowerment. This criticism is valid; however, after conducting field research in the states of Campeche, Mexico, and Ceará, Brazil, we found that women beneficiaries considered the health and nutrition lectures an invaluable component of the programmes. The interview data demonstrated that as a result of the talks, the beneficiaries were more aware of their rights as women and had gained better knowledge in health techniques to prevent their children and themselves from getting sick, which in the context of extreme poverty makes all the difference between being poor on the way to getting out of poverty, to being poor and drowning into intergenerational poverty because of health-related extra costs. ${ }^{62}$

Some critics of the CCTs state that the "naturalisation" of women as mothers and caregivers is intensified when there is a lack of holistic investments to alleviate their poverty (see for example Molyneux, 2006; Bradshaw, 2008). CCTs put significant time burdens on women, but only few offer capacity building that would enable women to graduate out of the programme by their own means. The critics state that, in fact, the increased time burden alone makes engagement in additional income generating activities less likely and therefore indirectly increases women's dependence on others to provide for them (Molyneux, 2007b). From a

\footnotetext{
${ }^{62}$ Many women mentioned that before attending the health and nutrition seminars, they did not know that food should not be left uncovered. They used to leave the food unrefrigerated and in contact with flies and mosquitoes, as they did not know they could transmit cholera and dengue. After the seminar, they reported taking better care of the food, and that the sickness rate of their families decreased significantly.
} 
material point of view, this still leaves women better off for the duration of the programme but from a more comprehensive view of poverty, this leaves little space for the transformation of gender relations or the increase of women's choices for themselves. We found that the educational talks opened up spaces for women to learn, to discuss their experiences and to connect with other women. Furthermore, these talks changed women's domestic violence awareness and improved their behaviour towards their children.

Other evaluations show that the transfers increase women's self-esteem, as they do not have to ask their husbands for money every time they need to make purchases. In this way, women also gain more confidence in their ability to judge independently what the household needs (Adato et al., 2000; Espinosa, 2006). This finding is relevant since the 1990 Human Development Report explicitly names "personal self-respect" (UNDP, 1990: 1) as an integral aspect of the human development process. In addition, the health and nutrition lectures provide women with an opportunity to leave the house and bond with other women. In some communities, women use these meetings to "share problems and solutions, and realise their common experiences" (Adato et al., 2000: 69). The women beneficiaries in this study also described this as an empowering experience.

Enhanced self-esteem, increased bargaining power, and reduced domestic violence were clearly positive effects on the situation of the women in our sample that go beyond the reduction of their poverty and point towards an increase in women's empowerment. However, attention must be paid for a number of reasons: firstly, the negative effect on women's time poverty is often ignored in impact evaluations but represents an important (gendered) impact when looking at comprehensive poverty reduction. Secondly, the empowering feeling of solidarity among women and their increased self-esteem seemed to be indirect effects of the programme design rather than planned-for outcomes. Thirdly, the positive effect on women's bargaining power, while stated as an explicit goal of the disbursement to women, is not directly attributable to the programme's design, as past work experience or education levels were more significant in explaining women's decision-making power (see Adato el al., 2000; Herzog, 2011).

This latter finding is important both from a conceptual and a policy point of view. It shows that a feeling of empowerment stems from an enhancement of women's capabilities in the sense of a comprehensive poverty reduction approach rather than from monetary inputs in a narrower sense. Furthermore, it implies that some CCTs could have a larger effect on women's decision-making power and empowerment if they offered vocational training or other means to increase women's capabilities to engage in income producing activities. This is important since, although women value Oportunidades and its benefits, what they want most 
is education that allows them to engage in productive activities (Adato et al., 2000: 82).

This study showed that policies need to be implemented that focus on helping women have access to better opportunities, such as flexible work hours, more parttime employment, family money, and maternity leave. In developed countries, maternity leave policies are in place. However, in most developing countries, maternity leaves are not always in place or they are only provided to women with access to formal labour. Thus women need to make a decision between family or work, which is detrimental to their own economies, and the national economies in general, especially since women constitute $50 \%$ of the population.

The findings derived from this research should be taken into account to design more holistic and integral public policies and welfare programmes. Policies such as universal access to education and health care, maternity leave, child care, unemployment and old age pensions should be in place for the entire population. Mexico, Brazil, and other developing countries are already taking steps in this direction; however, a large proportion of the vulnerable population still lacks access to basic protection. In this regard, policies can be drastically improved.

As it has been shown throughout this study, Oportunidades/Prospera and Bolsa Família do have an effect on the beneficiaries' access to labour market, intrahousehold decision-making power, and perceptions of self-worth and empowerment. However, in the case of Mexico, where women have access to educational talks, this effect appears to be greater. If the monetary transfers are paired with access to knowledge, the empowerment level of women in extreme poverty seems to rise more than in contexts where transfers are given without information. This suggests that structural policies that provide economic support together with education can create the seed for an empowerment process and improved well-being for this very vulnerable population.

Linked to this, we recommend to provide educational talks in Brazil regarding hygiene, education, nutrition, reproductive health and women's rights. Such characteristics of the programme design could foster a more comprehensive effect on the empowerment and well-being of the beneficiaries. Economic support linked to human capital investment has the potential to maximise the positive effect on women's lives.

Elaborating on what the beneficiaries in Mexico suggested, one of our key recommendations is to create channels for the participation of men in the programmes, both in Oportunidades/ Prospera and Bolsa Família. Many women mentioned that including men in the programme design and inviting them to the 
educational talks and programme meetings would be helpful: this inclusion could help men understand why women participate in the talks and why they need to use some time to follow up on the co-responsibilities. Furthermore, men could benefit and learn from the topics discussed and perhaps they could start changing their macho behaviours and teach their children new, more gender-equal values.

Men's education would also be another way to improve the adult education dimension of Oportunidades and Bolsa Família. Linked to what Adato and Roopnaraine (2010) point out, men's attitudes towards women and girls, and towards education and health, affect the extent to which women can profit from the benefits that CCTs offer. For example, whether women can keep the money of the transfers and decide how to spend it, whether girls can attend school, and whether women can use the health services offered or put into practice what they learn in the health talks - such as cervical cancer tests and family planning.

Another essential recommendation is to provide a link to economic opportunities for beneficiaries. While cash transfers and educational talks provide a first step towards poverty alleviation, gender equality, and better human capital, a connection should be made with productive opportunities and the labour market. During our field work, women's discussions consistently pointed towards skills that women would like to learn to engage with productive activities. This was revealing in terms of understanding women's aspirations and priorities, and the kind of government interventions that would fit them. Women spoke highly about Oportunidades and Bolsa Família and the benefits they brought to them in terms of extra money, and health and education improvements. However, they emphasised wanting employment options - income-generating options.

Taking this into account, it is important for the government to provide capacity building and access to productive options/income-generating activities. This access could also mean an exit strategy or "graduation" from the transfer programmes, when women could improve their economic level in a sustainable way and without depending on the government. 


\subsection{A Way Forward: Suggestions for Future Research}

CCTs have the potential to impact the beneficiaries' lives in a variety of ways. Furthermore, the countries where they are implemented are very diverse and highly populated, so there is a rich array of areas where impact analysis could be undertaken. Deriving from this study, we would suggest to analyse the long-term effect (accumulative effect) of CCTs on beneficiaries and their families.

Quantitative evaluations have been carried out in the areas of education, nutrition, health, etc. (see Adato et al., 2000; Parker and Skoufias, 2000; Quisumbing and De la Brière, 2000; Barrientos and De Jong, 2004; Britto, 2005; Foguel and Barros, 2008; Skoufias and Di Maro, 2008; Escobar Latapí and De la Rocha, 2009; Tavares, 2010; Veras Soares et al., 2010; De Brauw et al., 2012; Kabeer et al., 2012, among others). However, more in-depth long-term qualitative evaluations are needed. These qualitative evaluations could focus on the relationship between husbands and wives/partners in the household regarding decision-making, resource allocation and child-bearing decisions; on the dynamics between parents and children; and on the personal perception of empowerment that the beneficiaries have.

Further analyses on what men think about the programmes and what changes they perceive in their behaviour and in their household dynamics as a result of women's CCT receipts would also be useful. So far most evaluations have focused on women's perspectives, but it would also be important to incorporate men into the programmes and their evaluations. Ultimately, gender equality is about the dynamics between men and women, and the experiences of both genders should be studied.

Another important area for further study is the effect on children, particularly on girls. It would be important to find out whether the Oportunidades and Bolsa Família children have better human capital and better life opportunities than before receiving the programmes. After almost twenty years since the beginning of the programmes, there is already a generation of "graduates." These young adults could be evaluated regarding their education levels, employment levels, empowerment levels, etc. A crucial question would be whether or not these young men and women perceive themselves to be more empowered and to have better life opportunities and better access to income-generating activities than if they had not received the programme.

Probably the greatest potential empowerment effect of Oportunidades/Prospera and Bolsa Família is on girls' futures so they can grow up with more education, better health, more options for participation in the labour market, and a better 
understanding of their self-worth as women and human beings. Thus further evaluations in this area should be carried out.

After six years of undertaking $\mathrm{PhD}$ research, after six months of being in the field in Mexico's and Brazil's poorest communities, I know that there is still a lot to be done. Poverty and inequality in Mexico, Brazil, and the developing world require a deep understanding, not only in terms of numbers and impact rates, but in terms of human lives. We need to understand what it means to be a woman, a person, living in extreme poverty, without feeling the right to think or the opportunity of thinking of a better future. This situation kills hope and kills the spirit. If people feel they have no access to a better life for themselves and their children, they may stop trying and give up. We need to understand that this is a problem that regards all humanity. The government, international organisations, NGOs and research centres need to work together to understand this reality and design policy instruments that can generate a real effect on the lives of vulnerable populations.

By undertaking this $\mathrm{PhD}$ research, I hoped to shed light on a narrative that affects women in poverty all around the world. Lack of education, lack of resources, lack of ability to see a better future are a daily reality for women in poverty contexts in the developing and the developed world. It is my hope that policy makers will read this study and take into account the policy recommendations derived from the field work, listening to the voices of the poor.

After this long journey, I look back and feel gratitude for having had the opportunity to talk to these women. I feel grateful because I could go beyond policy-making in the headquarters and see the reality that women who live in extreme poverty face every day. I feel thankful that they decided to share their fears, problems, ideas, and dreams with me. By means of this book I hope to be able to give them a voice. In the field, I was taken by surprise by how eager they were to interact with me, to share their life stories and opinions. And that is when I realised that no one before had asked them what they thought about their lives, about how they make decisions, about their self-worth, and about their opinion on government policies that impact them. I want this study to be a voice for them.

There is still much to be accomplished, but I hope that this research is taken as a first effort to deeper qualitative research on women's empowerment and inclusive public policies to improve their lives. Because in the end, it is not only about numbers, money and poverty rates, it is about real lives, and the well-being and respect that all humans deserve. 


\section{Annexes}

\section{Annex 1. Interview Guide for Oportunidades Beneficiaries}

Name:

Age:

Community:

Education level:

\section{Marital Status:}

Year of Birth:

Number of people in household:

\section{General Questions}

1. Since when have you been receiving the cash transfer?

2. How many children do you have?

3. How many of your children go to school/get the scholarship?

4. What's the amount of your grant?

5. For how long more are you entitled to receive the transfer?

\begin{tabular}{|l|l|l|l|l|l|l|l|}
\hline $\begin{array}{l}\text { Date of } \\
\text { start- } \\
\text { transfers }\end{array}$ & $\begin{array}{l}\text { Years of } \\
\text { receiving } \\
\text { transfers }\end{array}$ & $\begin{array}{l}\text { Number } \\
\text { of } \\
\text { children }\end{array}$ & $\begin{array}{l}\text { Number of } \\
\text { children } \\
\text { with } \\
\text { scholarship }\end{array}$ & $\begin{array}{l}\text { Years to } \\
\text { receive } \\
\text { transfer }\end{array}$ & $\begin{array}{l}\text { Total } \\
\text { amount } \\
\text { of } \\
\text { transfer }\end{array}$ & $\begin{array}{l}\text { Total } \\
\text { income }\end{array}$ & $\begin{array}{l}\text { \% of } \\
\text { transfers } \\
\text { in total } \\
\text { income }\end{array}$ \\
\hline & & & & & & & \\
\hline
\end{tabular}

\section{Labour Market}

6. Do you have a paid job?

7. If yes, full-time or half-time? Is it formal or informal?

8. If yes, did you have a job before getting the transfers or did you get one after receiving it?

9. If not, did you have a job before getting the transfers? Did you stop working after receiving it? If so, why?

10. If not, have you considered getting a job ever since you get the transfers? Why?

11. Do you think your husband's perception of you working has changed ever since you get the transfers (more supportive, etc)? Why?

12. Has your own perception of paid job changed since you joined the programme? If so, why? 


\section{Intra-Household Decision-Making}

Please state if you do any of the following activities:

\begin{tabular}{|l|l|l|}
\hline A. Resource-allocation & Yes & No \\
\hline Spend money on the children without asking your husband & & \\
\hline Spend money for food without asking your husband & & \\
\hline Spend money for the house without asking your husband & & \\
\hline Spend money on yourself without asking your husband & & \\
\hline Save money for the future & & \\
\hline
\end{tabular}

\section{Comments:}

\begin{tabular}{|l|l|l|}
\hline B. Social affairs & Yes & No \\
\hline Leave the house unaccompanied without asking for permission & & \\
\hline Leave the house unaccompanied after asking for permission & & \\
\hline Meet female relatives & & \\
\hline Meet female friends & & \\
\hline Meet male relatives & & \\
\hline Meet male friends & & \\
\hline Engage in activities in your community/church/neighborhood & & \\
\hline
\end{tabular}

Comments:

\begin{tabular}{|l|l|l|}
\hline C. Child-related issues & Yes & No \\
\hline You let your sons attend school & & \\
\hline You let your daughters attend school & & \\
\hline You take your children to health facilities when needed & & \\
\hline $\begin{array}{l}\text { You buy clothes/shoes/school materials for your children when } \\
\text { needed }\end{array}$ & & \\
\hline You buy medicines for your children when needed & & \\
\hline
\end{tabular}

Comments:

\begin{tabular}{|l|l|l|}
\hline D. Personal decisions & Yes & No \\
\hline You chose your occupation & & \\
\hline You feel free to engage in the activities you want & & \\
\hline You choose your friends & & \\
\hline
\end{tabular}

\section{Comments:}




\section{E. Open Questions}

13. Who makes most decisions at home? You or your husband/partner?

14. Which decisions do you make?

15. Which decisions does your husband make?

16. Do you feel your opinion is valued in your household? (If yes) why?

17. Do think your opinion has the same value as the one of your husband? (If yes), why?

\section{Reproductive Health}

18. Do you attend health check-ups?

19. Do you use contraception methods (condoms, pills, etc)

20. Can you decide whether or not to have sexual relationships with your partner?

21. Can you decide whether or not to have children and when to have them?

\section{General Effect of the Programme on Empowerment}

22. Do you attend the educational talks?

23. Do you consider them useful? If so, what have you learned?

24. Have you changed some habits as a result of the talks? If yes, which ones?

25 . What changes have you observed in your behavior/attitudes since you get the Oportunidades transfer?

26. Do you feel more valued in within your home since you get the transfers? In what sense?

Thank you for your time and contribution! 


\section{Annex 2. Interview Guide for Bolsa Família Beneficiaries}

Name:

Age:

Community:

\section{Education level:}

\section{General Questions}

1. Since when have you been receiving the cash transfer?

2. How many children do you have?

3. How many of your children go to school/get the scholarship?

4. What's the amount of your grant?

5. For how long more are you entitled to receive the transfer?

\begin{tabular}{|l|l|l|l|l|l|l|l|}
\hline $\begin{array}{l}\text { Date of } \\
\text { start- } \\
\text { transfers }\end{array}$ & $\begin{array}{l}\text { Years of } \\
\text { receiving } \\
\text { transfers }\end{array}$ & $\begin{array}{l}\text { Number } \\
\text { of } \\
\text { children }\end{array}$ & $\begin{array}{l}\text { Number of } \\
\text { children } \\
\text { with } \\
\text { scholarship }\end{array}$ & $\begin{array}{l}\text { Years to } \\
\text { receive } \\
\text { transfer }\end{array}$ & $\begin{array}{l}\text { Total } \\
\text { amount } \\
\text { of } \\
\text { transfer }\end{array}$ & $\begin{array}{l}\text { Total } \\
\text { income }\end{array}$ & $\begin{array}{l}\text { \% of } \\
\text { transfers } \\
\text { in total } \\
\text { income }\end{array}$ \\
\hline & & & & & & & \\
\hline
\end{tabular}

\section{Labour Market}

6. Do you have a paid job?

7. If yes, full-time or half-time? Is it formal or informal?

8. If yes, did you have a job before getting the transfers or did you get one after receiving it?

9. If not, did you have a job before getting the transfers? Did you stop working after receiving it? If so, why?

10. If not, have you considered getting a job ever since you get the transfers? Why?

11. Do you think your husband's perception of you working has changed ever since you get the transfers (more supportive, etc)? Why?

12. Has your own perception of paid job changed since you joined the programme? If so, why? 


\section{Intra-Household Decision-Making}

Please state if you do any of the following activities:

\begin{tabular}{|l|l|l|}
\hline A. Resource-allocation & Yes & No \\
\hline Spend money on the children without asking your husband & & \\
\hline Spend money for food without asking your husband & & \\
\hline Spend money for the house without asking your husband & & \\
\hline Spend money on yourself without asking your husband & & \\
\hline Save money for the future & & \\
\hline
\end{tabular}

\section{Comments:}

\begin{tabular}{|l|l|l|}
\hline B. Social affairs & Yes & No \\
\hline Leave the house unaccompanied without asking for permission & & \\
\hline Leave the house unaccompanied after asking for permission & & \\
\hline Meet female relatives & & \\
\hline Meet female friends & & \\
\hline Meet male relatives & & \\
\hline Meet male friends & & \\
\hline Engage in activities in your community/church/neighborhood & & \\
\hline
\end{tabular}

Comments:

\begin{tabular}{|l|l|l|}
\hline C. Child-related issues & Yes & No \\
\hline You let your sons attend school & & \\
\hline You let your daughters attend school & & \\
\hline You take your children to health facilities when needed & & \\
\hline $\begin{array}{l}\text { You buy clothes/shoes/school materials for your children when } \\
\text { needed }\end{array}$ & & \\
\hline You buy medicines for your children when needed & & \\
\hline
\end{tabular}

Comments:

\begin{tabular}{|l|l|l|}
\hline D. Personal decisions & Yes & No \\
\hline You chose your occupation & & \\
\hline You feel free to engage in the activities you want & & \\
\hline You choose your friends & & \\
\hline
\end{tabular}

\section{Comments:}




\section{E. Open Questions}

13. Who makes most decisions at home? You or your husband/partner?

14. Which decisions do you make?

15. Which decisions does your husband make?

16. Do you feel your opinion is valued in your household? (If yes) why?

17. Do think your opinion has the same value as the one of your husband? (If yes), why?

\section{Reproductive Health}

18. Do you attend health check-ups?

19. Do you use contraception methods (condoms, pills, etc)

20. Can you decide whether or not to have sexual relationships with your partner?

21. Can you decide whether or not to have children and when to have them?

\section{General Effect of the Programme on Empowerment}

22. Do you attend the educational talks?

23. Do you consider them useful? If so, what have you learned?

24. Have you changed some habits as a result of the talks? If yes, which ones?

25 . What changes have you observed in your behavior/attitudes since you get the Bolsa Família transfer?

26. Do you feel more valued in within your home since you get the transfers? In what sense?

Thank you for your time and contribution! 
Name:

Age:

Community:

Education level:

\section{General Questions}

1. How many children do you have?

2 . How many of your children go to school?

3. Have you applied to get to programme

4. Why don't you receive the transfer?

\section{Labour Market}

5. Do you have a paid job?

6. If yes, full-time or half-time? Is it formal or informal?

7. If not, have you considered getting a job? Why or why not?

\section{Intra-Household Decision-Making}

Please state if you do any of the following activities:

\begin{tabular}{|l|l|l|}
\hline A. Resource-allocation & Yes & No \\
\hline Spend money on the children without asking your husband & & \\
\hline Spend money for food without asking your husband & & \\
\hline Spend money for the house without asking your husband & & \\
\hline Spend money on yourself without asking your husband & & \\
\hline Save money for the future & & \\
\hline
\end{tabular}

Comments:

\begin{tabular}{|l|l|l|}
\hline B. Social affairs & Yes & No \\
\hline Leave the house unaccompanied without asking for permission & & \\
\hline Leave the house unaccompanied after asking for permission & & \\
\hline Meet female relatives & & \\
\hline Meet female friends & & \\
\hline Meet male relatives & & \\
\hline Meet male friends & & \\
\hline Engage in activities in your community/church/neighborhood & & \\
\hline
\end{tabular}


Comments:

\begin{tabular}{|l|l|l|}
\hline C. Child-related issues & Yes & No \\
\hline You let your sons attend school & & \\
\hline You let your daughters attend school & & \\
\hline You take your children to health facilities when needed & & \\
\hline $\begin{array}{l}\text { You buy clothes/shoes/school materials for your children when } \\
\text { needed }\end{array}$ & & \\
\hline You buy medicines for your children when needed & & \\
\hline
\end{tabular}

Comments:

\begin{tabular}{|l|l|l|}
\hline D. Personal decisions & Yes & No \\
\hline You chose your occupation & & \\
\hline You feel free to engage in the activities you want & & \\
\hline You choose your friends & & \\
\hline
\end{tabular}

Comments:

\section{E. Open Questions}

8. Who makes most decisions at home? You or your husband/partner?

9. Which decisions do you make?

10. Which decisions does your husband make?

11. Do you feel your opinion is valued in your household? (If yes), why?

12. Do you think your opinion has the same value as the one of your husband? (If yes), why?

\section{Reproductive Health}

13. Do you use contraception methods (condoms, pills, etc)

14. Can you decide whether or not to have sexual relationships with your partner?

15. Can you decide whether or not to have children and when to have them?

16. Do you attend regular health check-ups?

Thank you for your time and contribution! 


\section{Annex 4. Oportunidades/Prospera's Transfers (in MXN) by Component, First}

\section{Semester 2015}

\begin{tabular}{|c|c|c|c|c|c|c|}
\hline Componen & Apoyos & Objetivo & Dirigido a & $\begin{array}{l}\text { Monto } \\
\text { mensual } \\
\text { Rural (\$) }\end{array}$ & $\begin{array}{l}\text { Monto } \\
\text { mensual } \\
\text { urbano } \\
(\$)\end{array}$ & $\begin{array}{c}\text { Monto } \\
\text { mensual } \\
\text { urbano } \\
\text { piloto (\$) }\end{array}$ \\
\hline \multirow[t]{4}{*}{ Alimentario } & Alimentario & $\begin{array}{l}\text { Mejorar la } \\
\text { cantidad, } \\
\text { calidad y } \\
\text { variedad de } \\
\text { alimentosque } \\
\text { consumen los } \\
\text { integrantesdel } \\
\text { hogarpara } \\
\text { mejorar su } \\
\text { estado de } \\
\text { nutrición }\end{array}$ & $\begin{array}{l}\text { Todoslosmiembrosdel } \\
\text { hogar en ambosesquemas } \\
\text { de corresponsabilidad. En el } \\
\text { esquema sin } \\
\text { corresponsabilidad, pueden } \\
\text { redireccionarse para que las } \\
\text { familiasadquieran productos } \\
\text { alimenticiosen el Sistema } \\
\text { Diconsa. }\end{array}$ & 335 & 335 & 335 \\
\hline & $\begin{array}{l}\text { Alimentario } \\
\text { complementario }\end{array}$ & $\begin{array}{l}\text { Compensarel } \\
\text { alza } \\
\text { internacional de } \\
\text { preciosde los } \\
\text { alimentos }\end{array}$ & $\begin{array}{l}\text { Todoslosintegrantes del } \\
\text { hogar (con y sin } \\
\text { corresponsabilidad). En el } \\
\text { esquema sin } \\
\text { corresponsabilidad, pueden } \\
\text { redireccionarse sus apoyos } \\
\text { para que lasfamilias } \\
\text { adquieran productos } \\
\text { alimenticiosen el Sistema } \\
\text { Diconsa. }\end{array}$ & 140 & 140 & 140 \\
\hline & $\begin{array}{l}\text { Alimentario sin } \\
\text { Hambre }\end{array}$ & Apoyar & $\begin{array}{l}\text { Todoslosintegrantes del } \\
\text { hogar en el esquema sin } \\
\text { corresponsabilidad a los } \\
\text { cualesse redireccionesu } \\
\text { apoyo para adquirir } \\
\text { productosalimenticiosen el } \\
\text { Sistema Diconsa. }\end{array}$ & 88 & 88 & No aplica \\
\hline & Infantil & $\begin{array}{l}\text { Fortalecer el } \\
\text { desarrollo de } \\
\text { losniños }\end{array}$ & $\begin{array}{l}\text { Integrantes de } 0 \text { a } 9 \text { años } \\
\text { que no sean becarios (hasta } \\
\text { tres integrantespor hogar, } \\
\text { con y sin corresponsabilidad) }\end{array}$ & 120 & 120 & 120 \\
\hline \multirow[t]{3}{*}{ Salud } & $\begin{array}{l}\text { Paquete Básico } \\
\text { Garantizado de } \\
\text { Salud- } \\
\text { CAUSES }\end{array}$ & $\begin{array}{l}\text { Atención } \\
\text { médica y } \\
\text { talleresde } \\
\text { autocuidadode } \\
\text { la salud }\end{array}$ & $\begin{array}{l}\text { Todoslosintegrantesdel } \\
\text { hogar }\end{array}$ & No aplica & No aplica & No aplica \\
\hline & Nutrición & $\begin{array}{l}\text { Seguimiento } \\
\text { nutricional }\end{array}$ & $\begin{array}{l}\text { Integrantesentre } 6 \text { y } 59 \\
\text { meses de edad y mujeres } \\
\text { embarazadaso en lactancia }\end{array}$ & \multicolumn{3}{|c|}{ Suplementos alimenticios } \\
\hline & $\begin{array}{l}\text { Comunicación } \\
\text { educativa de la } \\
\text { salud }\end{array}$ & $\begin{array}{l}\text { Fomentary } \\
\text { mejorarel } \\
\text { autocuidadode }\end{array}$ & Titularesy becarios de EMS $^{1}$ & No aplica & No aplica & No aplica \\
\hline
\end{tabular}

${ }^{48}$ Los cuatro aspectosrestantes fueron: un modelo de focalización multidimensional, un Modelo de Atención de Salud (MAS), entrega de losapoyospor medio de institucionesfinancieras(bancarización) y una Mesa de Atención Personalizada (MAPO). De 2009 a 2013 se incorporaron a este modelo hogares beneficiarios de 263 localidades urbanas que aún permanecen. Desde 2014 el programa ya no incorpora familias al modelo urbano piloto. 


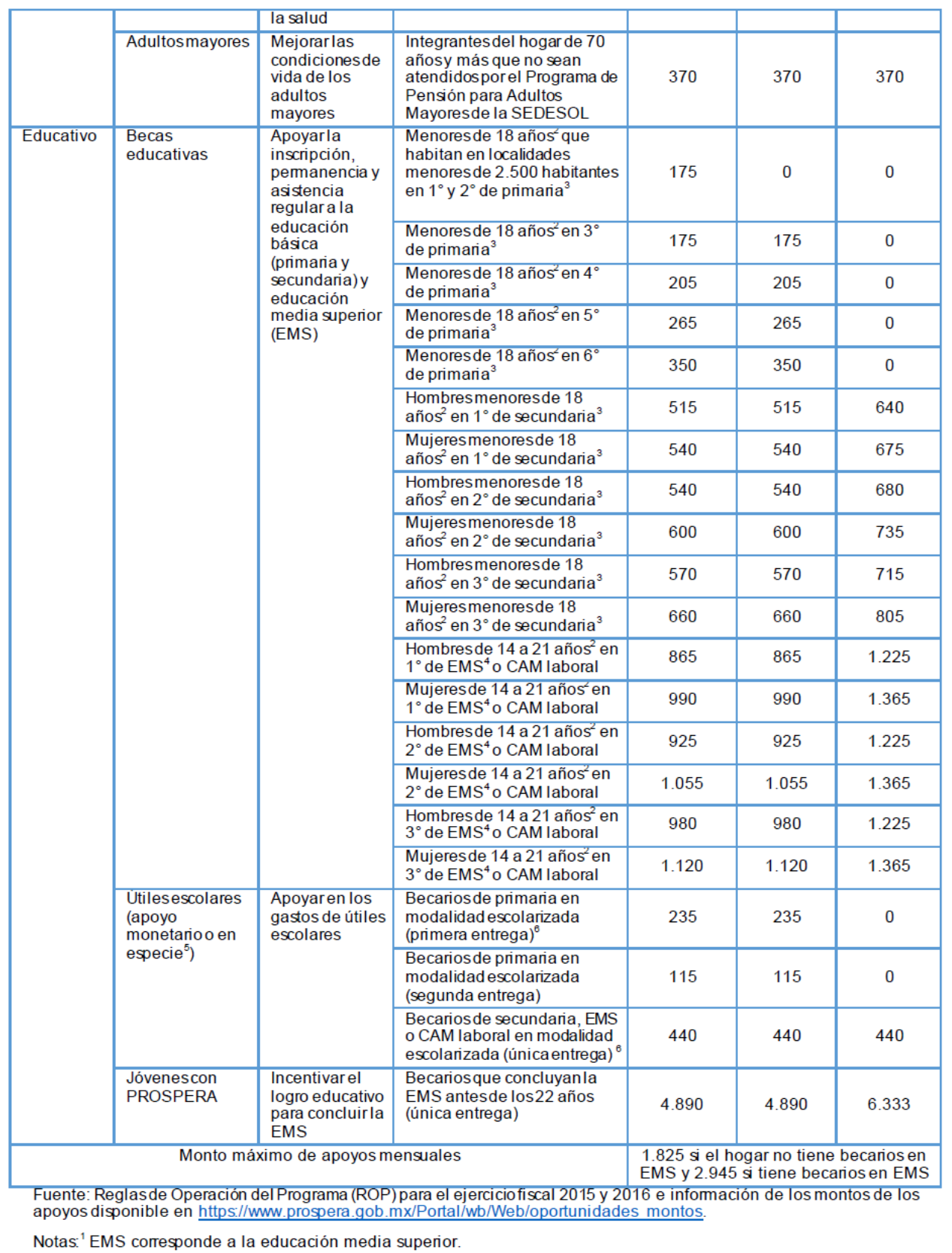

Source: Operational Rules of the Programme for 2015 and 2016, https://www.prospera.gob.mx/Portal/wb/oportunidades.montos 
Annex 5. Bolsa Família's Transfers (in R\$), 2014

\begin{tabular}{|c|c|c|c|c|}
\hline $\begin{array}{l}\text { Number of } \\
\text { pregnant women, } \\
\text { lactating mothers, } \\
\text { and children and } \\
\text { adolescents up to } \\
15 \text { years of age }\end{array}$ & $\begin{array}{l}\text { Youths } \\
16 \text { and } \\
17 \text { years } \\
\text { old }\end{array}$ & Type of benefit & $\begin{array}{l}\text { Value of the benefit for } \\
\text { families in EXTREME } \\
\text { POVERTY }\end{array}$ & $\begin{array}{l}\text { Value of the benefit for } \\
\text { families living in POVERTY } \\
\text { (calculated without the Basic } \\
\text { Benefit, which is paid only to } \\
\text { those is extreme poverty) }\end{array}$ \\
\hline 0 & 0 & BB & 77.00 & - \\
\hline 1 & 0 & $\mathrm{BB}+1 \mathrm{BV}$ & 112.00 & 35.00 \\
\hline 2 & 0 & $\mathrm{BB}+2 \mathrm{BV}$ & 147.00 & 70.00 \\
\hline 3 & 0 & $\mathrm{BB}+3 \mathrm{BV}$ & 182.00 & 105.00 \\
\hline 4 & 0 & $\mathrm{BB}+4 \mathrm{BV}$ & 217.00 & 140.00 \\
\hline 5 & 0 & $\mathrm{BB}+5 \mathrm{BV}$ & 252.00 & 175.00 \\
\hline 0 & 1 & $\mathrm{BB}+1 \mathrm{BVJ}$ & 119.00 & 42.00 \\
\hline 1 & 1 & $\mathrm{BB}+1 \mathrm{BV}+1 \mathrm{BVJ}$ & 154.00 & 77.00 \\
\hline 2 & 1 & $\mathrm{BB}+2 \mathrm{BV}+1 \mathrm{BVJ}$ & 189.00 & 112.00 \\
\hline 3 & 1 & $\mathrm{BB}+3 \mathrm{BV}+1 \mathrm{BVJ}$ & 224.00 & 147.00 \\
\hline 4 & 1 & $\mathrm{BB}+4 \mathrm{BV}+1 \mathrm{BVJ}$ & 259.00 & 182.00 \\
\hline 5 & 1 & $\mathrm{BB}+5 \mathrm{BV}+1 \mathrm{BVJ}$ & 294.00 & 217.00 \\
\hline 0 & 2 & $\mathrm{BB}+2 \mathrm{BVJ}$ & 161.00 & 84.00 \\
\hline 1 & 2 & $\mathrm{BB}+1 \mathrm{BV}+2 \mathrm{BVJ}$ & 196.00 & 119.00 \\
\hline 2 & 2 & $B B+2 B V+2 B V J$ & 231.00 & 154.00 \\
\hline 3 & 2 & $\mathrm{BB}+3 \mathrm{BV}+2 \mathrm{BVJ}$ & 266.00 & 189.00 \\
\hline 4 & 2 & $B B+4 B V+2 B V J$ & 301.00 & 224.00 \\
\hline 5 & 2 & $\mathrm{BB}+5 \mathrm{BV}+2 \mathrm{BVJ}$ & 336.00 & 259.00 \\
\hline
\end{tabular}

Source: Gazola (2015) 
Annex 6. Tables on Labour Market Participation, Intra-household Decision making, and Self-worth

Table A4.1 Interviewees' self-reported labour market participation

\begin{tabular}{|c|c|c|c|c|c|c|c|}
\hline \multirow{2}{*}{$\begin{array}{l}\text { Oportunidades } \\
\text { Beneficiaries }\end{array}$} & \multicolumn{3}{|c|}{ Paid job } & \multicolumn{2}{|c|}{ Full-time/Part-time } & \multicolumn{2}{|c|}{ Formal/Informal } \\
\hline & Yes & No & Total & Full time & Part-time & Formal & Informal \\
\hline Campeche & 9 & 1 & 10 & 0 & 9 & 8 & 1 \\
\hline Hecelchakán & 5 & 5 & 10 & 0 & 5 & 4 & 1 \\
\hline Tenabo & 6 & 4 & 10 & 0 & 6 & 3 & 3 \\
\hline \multirow{2}{*}{$\begin{array}{l}\text { Oportunidades } \\
\text { Non- } \\
\text { beneficiaries }\end{array}$} & \multicolumn{3}{|c|}{ Paid job } & \multicolumn{2}{|c|}{ Full-time/Part-time } & \multicolumn{2}{|c|}{ Formal/Informal } \\
\hline & Yes & No & Total & Full time & Part-time & Formal & Informal \\
\hline Campeche & 7 & 3 & 10 & 0 & 7 & 2 & 5 \\
\hline Hecelchakán & 5 & 5 & 10 & 0 & 5 & 1 & 4 \\
\hline Tenabo & 5 & 5 & 10 & 0 & 5 & 2 & 3 \\
\hline Total Mexico & 37 & 23 & 60 & 0 & 37 & 20 & 17 \\
\hline \multirow{2}{*}{$\begin{array}{l}\text { Bolsa Família } \\
\text { Beneficiaries }\end{array}$} & \multicolumn{3}{|c|}{ Paid job } & \multicolumn{2}{|c|}{ Full-time/Part-time } & \multicolumn{2}{|c|}{ Formal/Informal } \\
\hline & Yes & No & Total & Full time & Part-time & Formal & Informal \\
\hline Fortaleza & 3 & 7 & 10 & 0 & 3 & 3 & 0 \\
\hline Quixadá & 3 & 7 & 10 & 2 & 1 & 3 & 0 \\
\hline Mangue-Seco & 8 & 2 & 10 & 4 & 4 & 4 & 4 \\
\hline \multirow{2}{*}{$\begin{array}{l}\text { Bolsa Família } \\
\text { Non- } \\
\text { beneficiaries }\end{array}$} & \multicolumn{3}{|c|}{ Paid job } & \multicolumn{2}{|c|}{ Full-time/Part-time } & \multicolumn{2}{|c|}{ Formal/Informal } \\
\hline & Yes & No & Total & Full time & Part-time & Formal & Informal \\
\hline Fortaleza & 9 & 1 & 10 & 5 & 4 & 5 & 4 \\
\hline Quixadá & 9 & 1 & 10 & 2 & 7 & 6 & 3 \\
\hline Mangue-Seco & 6 & 4 & 10 & 0 & 6 & 0 & 6 \\
\hline Total Brazil & 38 & 22 & 60 & 13 & 25 & 21 & 17 \\
\hline $\begin{array}{l}\text { Total both } \\
\text { countries }\end{array}$ & 75 & 45 & 120 & 13 & 62 & 41 & 34 \\
\hline
\end{tabular}

Source: Author's own data 
Table A4.2 Interviewees' work before and after transfers and self-reported desire to work

\begin{tabular}{|c|c|c|c|c|c|c|}
\hline \multirow[t]{2}{*}{$\begin{array}{l}\text { Oportunidades } \\
\text { Beneficiaries }\end{array}$} & \multicolumn{2}{|c|}{$\begin{array}{l}\text { Work } \\
\text { before/after } \\
\text { transfers* }\end{array}$} & \multicolumn{2}{|c|}{$\begin{array}{l}\text { If no work, } \\
\text { before? }\end{array}$} & \multicolumn{2}{|c|}{$\begin{array}{l}\text { If no work, wants to } \\
\text { work? }\end{array}$} \\
\hline & Before & After & Yes & No & Yes & No \\
\hline Campeche & 9 & 0 & 0 & 1 & 0 & 1 \\
\hline Hecelchakán & 4 & 1 & 1 & 4 & 0 & 5 \\
\hline Tenabo & 3 & 3 & 2 & 2 & 3 & 1 \\
\hline \multirow{2}{*}{$\begin{array}{l}\text { Oportunidades } \\
\text { Non- } \\
\text { beneficiaries }\end{array}$} & \multicolumn{2}{|c|}{$\begin{array}{l}\text { Work before/after } \\
\text { transfers }\end{array}$} & \multicolumn{2}{|c|}{$\begin{array}{l}\text { If no work, } \\
\text { before? }\end{array}$} & \multicolumn{2}{|c|}{ If no work, wants to work? } \\
\hline & Before & After & Yes & No & Yes & No \\
\hline Campeche & NA & NA & 2 & 1 & 2 & 1 \\
\hline Hecelchakán & NA & NA & 1 & 4 & 0 & 5 \\
\hline Tenabo & NA & NA & 0 & 5 & 0 & 5 \\
\hline Total Mexico & 16 & 4 & 6 & 17 & 5 & 18 \\
\hline \multirow[t]{2}{*}{$\begin{array}{l}\text { Bolsa Família } \\
\text { Beneficiaries }\end{array}$} & \multicolumn{2}{|c|}{$\begin{array}{l}\text { Work before/after } \\
\text { transfers }\end{array}$} & \multicolumn{2}{|c|}{$\begin{array}{l}\text { If no work, } \\
\text { before? }\end{array}$} & \multicolumn{2}{|c|}{ If no work, wants to work? } \\
\hline & Before & After & Yes & No & Yes & No \\
\hline Fortaleza & 3 & 0 & 4 & 3 & 4 & 3 \\
\hline Quixadá & 2 & 1 & 7 & 0 & 1 & 6 \\
\hline Mangue-Seco & 4 & 4 & 2 & 0 & 1 & 1 \\
\hline \multirow{2}{*}{$\begin{array}{l}\text { Bolsa Família } \\
\text { Non- } \\
\text { beneficiaries }\end{array}$} & \multicolumn{2}{|c|}{$\begin{array}{l}\text { Work before/after } \\
\text { transfers }\end{array}$} & \multicolumn{2}{|c|}{$\begin{array}{l}\text { If no work, } \\
\text { before? }\end{array}$} & \multicolumn{2}{|c|}{ If no work, wants to work? } \\
\hline & Before & After & Yes & No & Yes & No \\
\hline Fortaleza & NA & NA & 0 & 1 & 1 & 0 \\
\hline Quixadá & NA & NA & 0 & 1 & 1 & 0 \\
\hline Mangue-Seco & NA & NA & 0 & 4 & 0 & 4 \\
\hline Total Brazil & 9 & 5 & 13 & 9 & 8 & 14 \\
\hline $\begin{array}{l}\text { Total both } \\
\text { countries }\end{array}$ & 25 & 9 & 19 & 26 & 13 & 32 \\
\hline
\end{tabular}

* Questions only for beneficiaries

Source: Author's own data 
Table A4.3 Classification of working and non-working beneficiaries

\begin{tabular}{|c|c|c|c|c|c|c|}
\hline \multirow[t]{2}{*}{$\begin{array}{l}\text { Oportunidades } \\
\text { Beneficiaries }\end{array}$} & \multirow[t]{2}{*}{ Work } & \multirow[t]{2}{*}{$\begin{array}{l}\text { Do not } \\
\text { work }\end{array}$} & \multicolumn{2}{|c|}{$\begin{array}{l}\text { Quit work after } \\
\text { transfers }\end{array}$} & \multirow[t]{2}{*}{$\begin{array}{l}\text { Worked after } \\
\text { transfers }\end{array}$} & \multirow[t]{2}{*}{$\begin{array}{l}\text { Never } \\
\text { worked }\end{array}$} \\
\hline & & & Children & Transfers & & \\
\hline Campeche & 9 & 1 & 0 & 0 & 0 & 1 \\
\hline Hecelchakán & 5 & 5 & 1 & 0 & 1 & 4 \\
\hline Tenabo & 6 & 4 & 2 & 0 & 3 & 2 \\
\hline Total Mexico & 20 & 10 & 3 & 0 & 4 & 7 \\
\hline \multirow[t]{2}{*}{$\begin{array}{l}\text { Bolsa Família } \\
\text { Beneficiaries }\end{array}$} & Work & $\begin{array}{l}\text { Do not } \\
\text { work }\end{array}$ & \multicolumn{2}{|c|}{$\begin{array}{l}\text { Quit work after } \\
\text { transfers }\end{array}$} & $\begin{array}{l}\text { Worked after } \\
\text { transfers }\end{array}$ & $\begin{array}{l}\text { Never } \\
\text { worked }\end{array}$ \\
\hline & & & Children & Transfers & & \\
\hline Fortaleza & 3 & 7 & 3 & 1 & 0 & 3 \\
\hline Quixadá & 3 & 7 & 5 & 2 & 1 & 0 \\
\hline Mangue-Seco & 8 & 2 & 2 & 0 & 4 & 0 \\
\hline Total Brazil & 14 & 16 & 10 & 3 & 5 & 3 \\
\hline $\begin{array}{ll}\text { Total } & \text { Both } \\
\text { Countries } & \end{array}$ & 34 & 26 & 13 & 3 & 9 & 10 \\
\hline
\end{tabular}

Source: Author's own data 
Table A5.1 Interviewees' self-reported decision-making power in the area of household expenditure

\begin{tabular}{|c|c|c|c|c|c|c|c|c|c|c|}
\hline \multirow[t]{2}{*}{$\begin{array}{l}\text { Oportunidades } \\
\text { beneficiaries }\end{array}$} & \multicolumn{2}{|c|}{$\begin{array}{l}\text { Expenditure } \\
\text { on Children }\end{array}$} & \multicolumn{2}{|c|}{$\begin{array}{l}\text { Food } \\
\text { Expenditure }\end{array}$} & \multicolumn{2}{|c|}{$\begin{array}{l}\text { Durable } \\
\text { Goods } \\
\text { Expenditure }\end{array}$} & \multicolumn{2}{|c|}{$\begin{array}{l}\text { Personal } \\
\text { Items } \\
\text { Expenditure }\end{array}$} & \multicolumn{2}{|c|}{ Saving } \\
\hline & Yes & No & Yes & No & Yes & No & Yes & No & Yes & No \\
\hline Campeche & 7 & 3 & 8 & 2 & 6 & 4 & 7 & 3 & 1 & 9 \\
\hline Hecelchakán & 9 & 1 & 10 & 0 & 7 & 3 & 9 & 1 & 7 & 3 \\
\hline Tenabo & 8 & 2 & 10 & 0 & 8 & 2 & 8 & 2 & 7 & 3 \\
\hline \multirow[t]{2}{*}{$\begin{array}{l}\text { Oportunidades } \\
\text { Non- } \\
\text { beneficiaries }\end{array}$} & \multicolumn{2}{|c|}{$\begin{array}{l}\text { Children } \\
\text { Expenditure }\end{array}$} & \multicolumn{2}{|c|}{$\begin{array}{l}\text { Food } \\
\text { Expenditure }\end{array}$} & \multicolumn{2}{|c|}{$\begin{array}{l}\text { Durable } \\
\text { goods } \\
\text { expenditure }\end{array}$} & \multicolumn{2}{|c|}{$\begin{array}{l}\text { Personal } \\
\text { items } \\
\text { expenditure }\end{array}$} & \multicolumn{2}{|c|}{ Saving } \\
\hline & Yes & No & Yes & No & Yes & No & Yes & No & Yes & No \\
\hline Campeche & 10 & 0 & 10 & 0 & 8 & 2 & 9 & 1 & 5 & 5 \\
\hline Hecelchakán & 9 & 1 & 10 & 0 & 8 & 2 & 9 & 1 & 3 & 7 \\
\hline Tenabo & 9 & 1 & 9 & 1 & 6 & 4 & 10 & 0 & 4 & 6 \\
\hline Total Mexico & 52 & 8 & 57 & 3 & 43 & 17 & 52 & 8 & 27 & 33 \\
\hline \multirow[t]{2}{*}{$\begin{array}{l}\text { Bolsa Família } \\
\text { Beneficiaries }\end{array}$} & \multicolumn{2}{|c|}{$\begin{array}{l}\text { Children } \\
\text { Expenditure }\end{array}$} & \multicolumn{2}{|c|}{$\begin{array}{l}\text { Food } \\
\text { Expenditure }\end{array}$} & \multicolumn{2}{|c|}{$\begin{array}{l}\text { Durable } \\
\text { goods } \\
\text { expenditure }\end{array}$} & \multicolumn{2}{|c|}{$\begin{array}{l}\text { Personal } \\
\text { items } \\
\text { expenditure }\end{array}$} & \multicolumn{2}{|c|}{ Saving } \\
\hline & Yes & No & Yes & No & Yes & No & Yes & No & Yes & No \\
\hline Fortaleza & 10 & 0 & 10 & 0 & 8 & 2 & 8 & 2 & 5 & 5 \\
\hline Quixadá & 7 & 3 & 6 & 4 & 5 & 5 & 8 & 2 & 4 & 6 \\
\hline Mangue-Seco & 8 & 2 & 10 & 0 & 8 & 2 & 9 & 1 & 5 & 5 \\
\hline \multirow[t]{2}{*}{$\begin{array}{l}\text { Bolsa Família } \\
\text { Non- } \\
\text { beneficiaries }\end{array}$} & \multicolumn{2}{|c|}{$\begin{array}{l}\text { Children } \\
\text { Expenditure }\end{array}$} & \multicolumn{2}{|c|}{$\begin{array}{l}\text { Food } \\
\text { Expenditure }\end{array}$} & \multicolumn{2}{|c|}{$\begin{array}{l}\text { Durable } \\
\text { goods } \\
\text { expenditure }\end{array}$} & \multicolumn{2}{|c|}{$\begin{array}{l}\text { Personal } \\
\text { items } \\
\text { expenditure }\end{array}$} & \multicolumn{2}{|c|}{ Saving } \\
\hline & Yes & No & Yes & No & Yes & No & Yes & No & Yes & No \\
\hline Fortaleza & 8 & 2 & 8 & 2 & 8 & 2 & 10 & 0 & 4 & 6 \\
\hline Quixadá & 9 & 1 & 10 & 0 & 9 & 1 & 10 & 0 & 5 & 5 \\
\hline Mangue-Seco & 10 & 0 & 9 & 1 & 9 & 1 & 10 & 0 & 8 & 2 \\
\hline Total Brazil & 52 & 8 & 53 & 7 & 47 & 13 & 55 & 5 & 31 & 29 \\
\hline $\begin{array}{l}\text { Total both } \\
\text { countries }\end{array}$ & 104 & 16 & 110 & 10 & 90 & 30 & 107 & 13 & 58 & 62 \\
\hline
\end{tabular}

Source: Author's own data 
Table A5.2 Interviewees' self-reported decision-making power in the area of children's issues

\begin{tabular}{|c|c|c|c|c|c|c|c|c|}
\hline \multirow[t]{2}{*}{$\begin{array}{l}\text { Oportunidades } \\
\text { beneficiaries }\end{array}$} & \multicolumn{2}{|c|}{$\begin{array}{l}\text { School } \\
\text { Attendance }\end{array}$} & \multicolumn{2}{|c|}{$\begin{array}{l}\text { Health Care } \\
\text { Attendance }\end{array}$} & \multicolumn{2}{|c|}{$\begin{array}{l}\text { Clothing and } \\
\text { School Items } \\
\text { Purchase }\end{array}$} & \multicolumn{2}{|c|}{$\begin{array}{l}\text { Medicines } \\
\text { Purchase }\end{array}$} \\
\hline & Yes & No & Yes & No & Yes & No & Yes & No \\
\hline Campeche & 10 & 0 & 10 & 0 & 10 & 0 & 10 & 0 \\
\hline Hecelchakán & 10 & 0 & 10 & 0 & 10 & 0 & 10 & 0 \\
\hline Tenabo & 10 & 0 & 10 & 0 & 10 & 0 & 10 & 0 \\
\hline \multirow[t]{2}{*}{$\begin{array}{l}\text { Oportunidades } \\
\text { non- } \\
\text { beneficiaries }\end{array}$} & \multicolumn{2}{|c|}{$\begin{array}{l}\text { School } \\
\text { Attendance }\end{array}$} & \multicolumn{2}{|c|}{$\begin{array}{l}\text { Health Care } \\
\text { Attendance }\end{array}$} & \multicolumn{2}{|c|}{$\begin{array}{l}\text { Clothing and } \\
\text { School Items } \\
\text { Purchase }\end{array}$} & \multicolumn{2}{|c|}{$\begin{array}{l}\text { Medicines } \\
\text { Purchase }\end{array}$} \\
\hline & Yes & No & Yes & No & Yes & No & Yes & No \\
\hline Campeche & 10 & 0 & 10 & 0 & 10 & 0 & 10 & 0 \\
\hline Hecelchakán & 10 & 0 & 10 & 0 & 10 & 0 & 10 & 0 \\
\hline Tenabo & 10 & 0 & 10 & 0 & 10 & 0 & 10 & 0 \\
\hline Total Mexico & 60 & 0 & 60 & 0 & 60 & 0 & 60 & 0 \\
\hline \multirow[t]{2}{*}{$\begin{array}{l}\text { Bolsa Família } \\
\text { beneficiaries }\end{array}$} & \multicolumn{2}{|c|}{$\begin{array}{l}\text { School } \\
\text { Attendance }\end{array}$} & \multicolumn{2}{|c|}{$\begin{array}{l}\text { Health Care } \\
\text { Attendance }\end{array}$} & \multicolumn{2}{|c|}{$\begin{array}{l}\text { Clothing and } \\
\text { School Items } \\
\text { Purchase }\end{array}$} & \multicolumn{2}{|c|}{$\begin{array}{l}\text { Medicines } \\
\text { Purchase }\end{array}$} \\
\hline & Yes & No & Yes & No & Yes & No & Yes & No \\
\hline Fortaleza & 10 & 0 & 10 & 0 & 9 & 1 & 9 & 1 \\
\hline Quixadá & 10 & 0 & 10 & 0 & 10 & 0 & 10 & 0 \\
\hline Mangue-Seco & 10 & 0 & 10 & 0 & 10 & 0 & 10 & 0 \\
\hline \multirow[t]{2}{*}{$\begin{array}{l}\text { Bolsa Família } \\
\text { non- } \\
\text { beneficiaries }\end{array}$} & \multicolumn{2}{|c|}{$\begin{array}{l}\text { School } \\
\text { Attendance }\end{array}$} & \multicolumn{2}{|c|}{$\begin{array}{l}\text { Health Care } \\
\text { Attendance }\end{array}$} & \multicolumn{2}{|c|}{$\begin{array}{l}\text { Clothing and } \\
\text { School Items } \\
\text { Purchase }\end{array}$} & \multicolumn{2}{|c|}{$\begin{array}{l}\text { Medicines } \\
\text { Purchase }\end{array}$} \\
\hline & Yes & No & Yes & No & Yes & No & Yes & No \\
\hline Fortaleza & 10 & 0 & 10 & 0 & 10 & 0 & 10 & 0 \\
\hline Quixadá & 10 & 0 & 10 & 0 & 10 & 0 & 10 & 0 \\
\hline Mangue-Seco & 10 & 0 & 10 & 0 & 10 & 0 & 10 & 0 \\
\hline Total Brazil & 60 & 0 & 60 & 0 & 59 & 1 & 59 & 1 \\
\hline $\begin{array}{l}\text { Total Both } \\
\text { countries }\end{array}$ & 120 & 0 & 120 & 0 & 119 & 1 & 119 & 1 \\
\hline
\end{tabular}

Source: Author's own data 
Table A5.3 Interviewees' self-reported decision-making power in the area of personal decisions

\begin{tabular}{|c|c|c|c|c|c|c|c|}
\hline \multirow[t]{2}{*}{$\begin{array}{l}\text { Oportunidades } \\
\text { beneficiaries }\end{array}$} & \multicolumn{2}{|c|}{ Choose Occupation } & \multicolumn{2}{|c|}{$\begin{array}{l}\text { Participation } \\
\text { Activities }\end{array}$} & \multirow[t]{2}{*}{ in } & \multirow{2}{*}{$\begin{array}{ll}\text { Ability to } \\
\text { Friends } \\
\text { Yes }\end{array}$} & \multirow{2}{*}{$\begin{array}{l}\text { Choose } \\
\text { No }\end{array}$} \\
\hline & Yes & No & Yes & No & & & \\
\hline Campeche & 8 & 2 & 8 & 2 & & 9 & 1 \\
\hline Hecelchakán & 10 & 0 & 10 & 0 & & 10 & 0 \\
\hline Tenabo & 9 & 1 & 10 & 0 & & 10 & 0 \\
\hline \multirow[t]{2}{*}{$\begin{array}{l}\text { Oportunidades } \\
\text { non- } \\
\text { beneficiaries }\end{array}$} & \multicolumn{2}{|c|}{ Choose Occupation } & \multicolumn{2}{|c|}{$\begin{array}{l}\text { Participation } \\
\text { Activities }\end{array}$} & in & \multicolumn{2}{|l|}{ Friendships } \\
\hline & Yes & No & Yes & No & & Yes & No \\
\hline Campeche & 7 & 3 & 10 & 0 & & 10 & 0 \\
\hline Hecelchakán & 10 & 0 & 10 & 0 & & 10 & 0 \\
\hline Tenabo & 10 & 0 & 10 & 0 & & 10 & 0 \\
\hline Total Mexico & 54 & 6 & 58 & 2 & & 59 & 1 \\
\hline \multirow[t]{2}{*}{$\begin{array}{l}\text { Bolsa Família } \\
\text { beneficiaries }\end{array}$} & \multicolumn{2}{|c|}{ Choose Occupation } & \multicolumn{2}{|c|}{$\begin{array}{l}\text { Participation } \\
\text { Activities }\end{array}$} & in & $\begin{array}{l}\text { Ability to } \\
\text { Friendships }\end{array}$ & Choose \\
\hline & Yes & No & Yes & No & & Yes & No \\
\hline Fortaleza & 8 & 2 & 8 & 2 & & 8 & 2 \\
\hline Quixadá & 8 & 2 & 10 & 0 & & 8 & 2 \\
\hline Mangue-Seco & 10 & 0 & 10 & 0 & & 7 & 3 \\
\hline \multirow[t]{2}{*}{$\begin{array}{l}\text { Bolsa Família } \\
\text { non- } \\
\text { beneficiaries }\end{array}$} & \multicolumn{2}{|c|}{ Choose Occupation } & \multicolumn{2}{|c|}{$\begin{array}{l}\text { Participation } \\
\text { Activities }\end{array}$} & in & $\begin{array}{l}\text { Ability to } \\
\text { Friendships }\end{array}$ & Choose \\
\hline & Yes & No & Yes & No & & Yes & No \\
\hline Fortaleza & 8 & 2 & 9 & 1 & & 7 & 3 \\
\hline Quixadá & 10 & 0 & 10 & 0 & & 9 & 1 \\
\hline Mangue-Seco & 10 & 0 & 10 & 0 & & 10 & 0 \\
\hline Total Brazil & 54 & 6 & 57 & 3 & & 49 & 11 \\
\hline $\begin{array}{l}\text { Total both } \\
\text { countries }\end{array}$ & 108 & 12 & 115 & 5 & & 108 & 12 \\
\hline
\end{tabular}

Source: Author's own data 
Table A5.4 Interviewees' self-reported decision-making power in the area of reproductive health

\begin{tabular}{|c|c|c|c|c|c|c|c|c|}
\hline \multirow[t]{2}{*}{$\begin{array}{l}\text { Oportunidades } \\
\text { beneficiaries }\end{array}$} & \multicolumn{2}{|c|}{$\begin{array}{l}\text { Use of } \\
\text { contraception }\end{array}$} & \multicolumn{2}{|c|}{$\begin{array}{l}\text { Control over } \\
\text { sexual } \\
\text { relations } \\
\end{array}$} & \multicolumn{2}{|c|}{$\begin{array}{l}\text { Control over } \\
\text { child-bearing }\end{array}$} & \multicolumn{2}{|c|}{$\begin{array}{l}\text { Attendance at } \\
\text { health check-ups }\end{array}$} \\
\hline & Yes & No & Yes & No & Yes & No & Yes & $\mathrm{No}$ \\
\hline Campeche & 6 & 4 & 8 & 2 & 10 & 0 & 8 & 2 \\
\hline Hecelchakán & 10 & 0 & 9 & 1 & 8 & 2 & 10 & 0 \\
\hline Tenabo & 7 & 3 & 9 & 1 & 8 & 2 & 9 & 1 \\
\hline \multirow[t]{2}{*}{$\begin{array}{l}\text { Oportunidades } \\
\text { Non- } \\
\text { beneficiaries }\end{array}$} & \multicolumn{2}{|c|}{$\begin{array}{l}\text { Use of } \\
\text { contraception }\end{array}$} & \multicolumn{2}{|c|}{$\begin{array}{l}\text { Control over } \\
\text { sexual } \\
\text { relations }\end{array}$} & \multicolumn{2}{|c|}{$\begin{array}{l}\text { Control over } \\
\text { child-bearing }\end{array}$} & \multicolumn{2}{|c|}{$\begin{array}{l}\text { Attendance at } \\
\text { health check-ups }\end{array}$} \\
\hline & Yes & No & Yes & No & Yes & No & Yes & No \\
\hline Campeche & 8 & 2 & 10 & 0 & 10 & 0 & 10 & 0 \\
\hline Hecelchakán & 10 & 0 & 10 & 0 & 9 & 1 & 10 & 0 \\
\hline Tenabo & 10 & 0 & 9 & 1 & 9 & 1 & 10 & 0 \\
\hline Total Mexico & 51 & 9 & 55 & 5 & 54 & 6 & 57 & 3 \\
\hline \multirow[t]{2}{*}{$\begin{array}{l}\text { Bolsa Família } \\
\text { beneficiaries }\end{array}$} & \multicolumn{2}{|c|}{$\begin{array}{l}\text { Use of } \\
\text { contraception }\end{array}$} & \multicolumn{2}{|c|}{$\begin{array}{l}\text { Control over } \\
\text { sexual } \\
\text { relations }\end{array}$} & \multicolumn{2}{|c|}{$\begin{array}{l}\text { Control over } \\
\text { child-bearing }\end{array}$} & \multicolumn{2}{|c|}{$\begin{array}{l}\text { Attendance at } \\
\text { health check-ups }\end{array}$} \\
\hline & Yes & No & Yes & No & Yes & No & Yes & No \\
\hline Fortaleza & 9 & 1 & 8 & 2 & 5 & 5 & 10 & 0 \\
\hline Quixadá & 7 & 3 & 9 & 1 & 5 & 5 & 10 & 0 \\
\hline Mangue-Seco & 7 & 3 & 6 & 4 & 8 & 2 & 10 & 0 \\
\hline \multirow[t]{2}{*}{$\begin{array}{l}\text { Bolsa Família } \\
\text { non- } \\
\text { beneficiaries }\end{array}$} & \multicolumn{2}{|c|}{$\begin{array}{l}\text { Use of } \\
\text { contraception }\end{array}$} & \multicolumn{2}{|c|}{$\begin{array}{l}\text { Control over } \\
\text { sexual } \\
\text { relations }\end{array}$} & \multicolumn{2}{|c|}{$\begin{array}{l}\text { Control over } \\
\text { child-bearing }\end{array}$} & \multicolumn{2}{|c|}{$\begin{array}{l}\text { Attendance at } \\
\text { health check-ups }\end{array}$} \\
\hline & Yes & No & Yes & No & Yes & No & Yes & No \\
\hline Fortaleza & 9 & 1 & 7 & 3 & 3 & 7 & 10 & 0 \\
\hline Quixadá & 8 & 2 & 9 & 1 & 4 & 6 & 9 & 1 \\
\hline Mangue-Seco & 7 & 3 & 8 & 2 & 5 & 5 & 9 & 1 \\
\hline Total Brazil & 47 & 13 & 47 & 13 & 30 & 30 & 58 & 2 \\
\hline $\begin{array}{l}\text { Total both } \\
\text { countries }\end{array}$ & 98 & 22 & 102 & 18 & 84 & 36 & 115 & 5 \\
\hline
\end{tabular}

Source: Author's own data 
Table A5.5 Oportunidades' beneficiaries and non-beneficiaries' self-reported decision-making power in the area of mobility

\begin{tabular}{|c|c|c|c|c|c|c|c|c|}
\hline \multirow[b]{2}{*}{$\begin{array}{l}\text { Oportunidades } \\
\text { beneficiaries }\end{array}$} & \multicolumn{2}{|c|}{$\begin{array}{l}\text { Leave house } \\
\text { alone without } \\
\text { permission }\end{array}$} & \multicolumn{2}{|c|}{$\begin{array}{l}\text { Leave house } \\
\text { alone with } \\
\text { permission }\end{array}$} & \multicolumn{2}{|c|}{$\begin{array}{l}\text { Leave house } \\
\text { accompanied } \\
\text { without permission }\end{array}$} & \multicolumn{2}{|c|}{$\begin{array}{l}\text { Leave house } \\
\text { accompanied with } \\
\text { permission }\end{array}$} \\
\hline & Yes & $\mathrm{No}$ & Yes & $\mathrm{No}$ & Yes & $\mathrm{No}$ & Yes & $\mathrm{No}$ \\
\hline Campeche & 4 & 6 & 6 & 4 & 9 & 1 & 10 & 0 \\
\hline Hecelchakán & 6 & 4 & 9 & 1 & 6 & 4 & 9 & 1 \\
\hline Tenabo & 6 & 4 & 10 & 0 & 9 & 1 & 10 & 0 \\
\hline $\begin{array}{l}\text { Oportunidades } \\
\text { Non- } \\
\text { beneficiaries }\end{array}$ & Yes & No & Yes & No & Yes & No & Yes & No \\
\hline Campeche & 6 & 4 & 9 & 1 & 9 & 1 & 9 & 1 \\
\hline Hecelchakán & 6 & 4 & 10 & 0 & 10 & 0 & 10 & 0 \\
\hline Tenabo & 5 & 5 & 10 & 0 & 10 & 0 & 10 & 0 \\
\hline \multirow[t]{2}{*}{ Total Mexico } & 33 & 27 & 54 & 6 & 53 & 7 & 58 & 2 \\
\hline & \multicolumn{2}{|c|}{$\begin{array}{l}\text { Meet female } \\
\text { relatives }\end{array}$} & \multicolumn{2}{|c|}{$\begin{array}{l}\text { Meet female } \\
\text { friends }\end{array}$} & \multicolumn{2}{|c|}{ Meet male relatives } & \multicolumn{2}{|c|}{ Meet male friends } \\
\hline $\begin{array}{l}\text { Oportunidades } \\
\text { beneficiaries }\end{array}$ & Yes & No & Yes & No & Yes & No & Yes & No \\
\hline Campeche & 7 & 3 & 6 & 4 & 5 & 5 & 2 & 8 \\
\hline Hecelchakán & 10 & 0 & 8 & 2 & 7 & 3 & 0 & 10 \\
\hline Tenabo & 9 & 1 & 7 & 3 & 3 & 7 & 0 & 10 \\
\hline $\begin{array}{l}\text { Oportunidades } \\
\text { Non- } \\
\text { beneficiaries }\end{array}$ & Yes & No & Yes & No & Yes & No & Yes & No \\
\hline Campeche & 10 & 0 & 9 & 1 & 6 & 4 & 3 & 7 \\
\hline Hecelchakán & 10 & 0 & 6 & 4 & 6 & 4 & 1 & 9 \\
\hline Tenabo & 10 & 0 & 7 & 3 & 4 & 6 & 0 & 10 \\
\hline Total Mexico & 56 & 4 & 43 & 17 & 31 & 29 & 6 & 54 \\
\hline
\end{tabular}

Source: Author's own data 
Table A5.6 Bolsa Família's beneficiaries and non-beneficiaries' self-reported decision-making power in the area of mobility

\begin{tabular}{|c|c|c|c|c|c|c|c|c|}
\hline \multirow[b]{2}{*}{$\begin{array}{l}\text { Bolsa Família } \\
\text { beneficiaries }\end{array}$} & \multicolumn{2}{|c|}{$\begin{array}{l}\text { Leave house } \\
\text { alone without } \\
\text { permission }\end{array}$} & \multicolumn{2}{|c|}{$\begin{array}{l}\text { Leave house } \\
\text { alone with } \\
\text { permission }\end{array}$} & \multicolumn{2}{|c|}{$\begin{array}{l}\text { Leave house } \\
\text { accompanied } \\
\text { without permission }\end{array}$} & \multicolumn{2}{|c|}{$\begin{array}{l}\text { Leave house } \\
\text { accompanied with } \\
\text { permission }\end{array}$} \\
\hline & Yes & No & Yes & No & Yes & No & Yes & No \\
\hline Fortaleza & 2 & 8 & 10 & 0 & 6 & 4 & 9 & 1 \\
\hline Quixadá & 4 & 6 & 8 & 2 & 10 & 0 & 10 & 0 \\
\hline Mangue-Seco & 3 & 7 & 10 & 0 & 7 & 3 & 10 & 0 \\
\hline $\begin{array}{l}\text { Bolsa Família } \\
\text { Non- } \\
\text { beneficiaries }\end{array}$ & Yes & No & Yes & No & Yes & No & Yes & No \\
\hline Fortaleza & 9 & 1 & 10 & 0 & 10 & 0 & 10 & 0 \\
\hline Quixadá & 9 & 1 & 10 & 0 & 9 & 1 & 10 & 0 \\
\hline Mangue-Seco & 4 & 6 & 10 & 0 & 8 & 2 & 10 & 0 \\
\hline \multirow[t]{2}{*}{ Total Brazil } & 31 & 29 & 58 & 2 & 50 & 10 & 59 & 1 \\
\hline & \multicolumn{2}{|c|}{$\begin{array}{l}\text { Meet female } \\
\text { relatives }\end{array}$} & \multicolumn{2}{|c|}{$\begin{array}{l}\text { Meet female } \\
\text { friends }\end{array}$} & \multicolumn{2}{|c|}{ Meet male relatives } & \multicolumn{2}{|c|}{ Meet male friends } \\
\hline $\begin{array}{l}\text { Bolsa Família } \\
\text { beneficiaries }\end{array}$ & Yes & No & Yes & No & Yes & No & Yes & No \\
\hline Fortaleza & 10 & 0 & 7 & 3 & 6 & 4 & 1 & 9 \\
\hline Quixadá & 10 & 0 & 10 & 0 & 10 & 0 & 1 & 9 \\
\hline Mangue-Seco & 10 & 0 & 6 & 4 & 5 & 5 & 1 & 9 \\
\hline $\begin{array}{l}\text { Bolsa Família } \\
\text { Non- } \\
\text { beneficiaries }\end{array}$ & Yes & No & Yes & No & Yes & No & Yes & No \\
\hline Fortaleza & 10 & 0 & 10 & 0 & 8 & 2 & 5 & 5 \\
\hline Quixadá & 10 & 0 & 10 & 0 & 8 & 2 & 2 & 8 \\
\hline Mangue-Seco & 10 & 0 & 9 & 1 & 7 & 3 & 0 & 10 \\
\hline Total Brazil & 60 & 0 & 52 & 8 & 44 & 16 & 10 & 50 \\
\hline
\end{tabular}

Source: Author's own data 
Table A5.7 Interviewees' self-reports about person who makes most decisions in the household

\begin{tabular}{llll}
\hline & \multicolumn{3}{l}{ Who makes most decisions in the household? } \\
\hline Oportunidades Beneficiaries & Both & Wife & Husband \\
\hline Campeche & 6 & 1 & 3 \\
Hecelchakán & 4 & 3 & 3 \\
\hline Tenabo & 6 & 1 & 3 \\
\hline Oportunidades Non-beneficiaries & Both & Wife & Husband \\
\hline Campeche & 6 & 3 & 1 \\
\hline Hecelchakán & 6 & 2 & 2 \\
\hline Tenabo & 5 & 2 & 3 \\
\hline Total Mexico & 33 & 12 & 15 \\
\hline Bolsa Família beneficiaries & Both & Wife & Husband \\
\hline Fortaleza & 2 & 4 & 4 \\
\hline Quixadá & 3 & 5 & 2 \\
\hline Mangue-Seco & 4 & 4 & 2 \\
\hline Bolsa Família non-beneficiaries & Both & Wife & Husband \\
\hline Fortaleza & 3 & 3 & 4 \\
\hline Quixadá & 3 & 4 & 3 \\
\hline Mangue-Seco & 4 & 3 & 3 \\
\hline Total Brazil & 19 & 23 & 18 \\
\hline Total both countries & 52 & 35 & 33 \\
\hline
\end{tabular}

Source: Author's own data 
Table A6.1 Interviewees' own perceptions of opinion valued at home and if their opinion has the same weight as their husbands'

\begin{tabular}{|c|c|c|c|c|c|c|c|}
\hline \multirow[b]{2}{*}{$\begin{array}{l}\text { Beneficiaries } \\
\text { Oportunidades }\end{array}$} & \multicolumn{3}{|c|}{ Opinion valued at home } & \multicolumn{4}{|c|}{ Opinion same weight as husband } \\
\hline & Yes & No & Total & $\begin{array}{l}\text { Same } \\
\text { Weight }\end{array}$ & $\begin{array}{l}\text { Husband } \\
\text { more }\end{array}$ & $\begin{array}{l}\text { Wife } \\
\text { more }\end{array}$ & Total \\
\hline Campeche & 7 & 3 & 10 & 5 & 5 & 0 & 10 \\
\hline Hecelchakán & 10 & 0 & 10 & 5 & 4 & 1 & 10 \\
\hline Tenabo & 10 & 0 & 10 & 6 & 4 & 0 & 10 \\
\hline \multirow[t]{2}{*}{$\begin{array}{l}\text { Non } \\
\text { beneficiaries } \\
\text { Oportunidades }\end{array}$} & \multicolumn{3}{|c|}{ Opinion valued at home } & \multicolumn{4}{|c|}{ Opinion same weight as husband } \\
\hline & Yes & No & Total & $\begin{array}{l}\text { Same } \\
\text { Weight }\end{array}$ & $\begin{array}{l}\text { Husband } \\
\text { more }\end{array}$ & $\begin{array}{l}\text { Wife } \\
\text { more }\end{array}$ & Total \\
\hline Campeche & 9 & 1 & 10 & 7 & 1 & 2 & 10 \\
\hline Hecelchakán & 10 & 0 & 10 & 7 & 2 & 1 & 10 \\
\hline Tenabo & 10 & 0 & 10 & 5 & 3 & 2 & 10 \\
\hline Total Mexico & 56 & 4 & 60 & 35 & 19 & 6 & 60 \\
\hline \multirow{2}{*}{$\begin{array}{l}\text { Beneficiaries } \\
\text { Bolsa Família }\end{array}$} & \multicolumn{3}{|c|}{ Opinion valued at home } & \multicolumn{4}{|c|}{ Opinion same weight as husband } \\
\hline & Yes & No & Total & $\begin{array}{l}\text { Same } \\
\text { Weight }\end{array}$ & $\begin{array}{l}\text { Husband } \\
\text { more }\end{array}$ & $\begin{array}{l}\text { Wife } \\
\text { more }\end{array}$ & Total \\
\hline Fortaleza & 8 & 2 & 10 & 4 & 3 & 3 & 10 \\
\hline Quixadá & 6 & 4 & 10 & 3 & 3 & 4 & 10 \\
\hline Mangue-Seco & 9 & 1 & 10 & 3 & 3 & 4 & 10 \\
\hline \multirow{3}{*}{$\begin{array}{l}\text { Non } \\
\text { Beneficiaries } \\
\text { Bolsa Família }\end{array}$} & \multirow{2}{*}{\multicolumn{3}{|c|}{ Opinion valued at home }} & \multirow{2}{*}{\multicolumn{4}{|c|}{ Opinion same weight as husband }} \\
\hline & & & & & & & \\
\hline & Yes & No & Total & $\begin{array}{l}\text { Same } \\
\text { Weight }\end{array}$ & $\begin{array}{l}\text { Husband } \\
\text { more }\end{array}$ & $\begin{array}{l}\text { Wife } \\
\text { more }\end{array}$ & Total \\
\hline Fortaleza & 8 & 2 & 10 & 5 & 3 & 2 & 10 \\
\hline Quixadá & 9 & 1 & 10 & 7 & 3 & 0 & 10 \\
\hline Mangue-Seco & 9 & 1 & 10 & 5 & 3 & 2 & 10 \\
\hline Total Brazil & 49 & 11 & 60 & 27 & 18 & 15 & 60 \\
\hline $\begin{array}{l}\text { Total Both } \\
\text { Countries }\end{array}$ & 105 & 15 & 120 & 62 & 37 & 21 & 120 \\
\hline
\end{tabular}

Source: Author's own data 


\section{Valorization Addendum}

This addendum discusses the valorization opportunities presented within this doctoral dissertation. It complies with article 23 of the "Regulation governing the attainment of doctoral degrees" at Maastricht University, decreed by the resolution of the Board of Deans in 2013.

\section{Relevance}

This dissertation addresses the effect that government-led conditional cash transfer programmes have on women's empowerment in three main areas - labour market participation, intra-household decision-making, and self-worth. The relevance of this topic stems from the fact that women are the largest vulnerable group on the planet due to the existing inequality in access to assets and resources. In the developing world, in particular, this inequality can have extreme outcomes, such as lower nourishment and literacy rates for girls, and an increasing mortality rate for women, especially during pregnancy and child-birth.

By extracting lessons learnt and policy recommendations from field work conducted by the author in Brazil and Mexico, this dissertation can have a two-fold relevance. First, it can have an economic effect by improving the efficiency of these poverty alleviation programmes. By knowing which features of the programmes work better and which ones can be improved, the cost-efficiency can be enhanced, and the financing and budgeting of these public policies can be improved. Second, it can have a social effect by improving the lives of the beneficiaries and their families. If the policy recommendations of this dissertation are implemented in policy-making, the programmes could have a better effect and women could maximise their benefits. By receiving educational talks and learning about how to use the CCT resources, about health and nutrition, and about their rights, women could improve the effect that receiving CCTs has on their and their families' lives. 
If the monetary transfers are paired with access to knowledge, the empowerment level of women in extreme poverty could rise more than in contexts where transfers are given without information. This suggests that structural policies that provide economic support together with education can create the seed for an empowerment process and improved well-being for this very vulnerable population.

\section{Target groups}

In addition to the academic community, the results of this research may be of interest to policy makers, governments, civil society organisations - national and international, and think-tanks which are involved in the design of public policies and welfare programmes for the poorest population. The policy recommendations derived from this research can be implemented by the aforementioned actors in order to design public policies or to improve existing policy interventions for poverty alleviation.

\section{Products}

From this dissertation, three main products can be extracted. First, the interview guides for the beneficiaries and non-beneficiaries could be used as guidelines for further qualitative research. Second, as a result from the field work, it is clear that educational talks should be implemented as a part of the design of conditional cash transfers programmes. This would make CCTs more efficient in their results by providing better tools for the beneficiary population. Third, the enhanced empowerment framework, specifically designed to evaluate empowerment processes in Chapter 6, can be used by policy makers to appraise the effect conditional cash transfer programmes are having in different countries or communities.

In general, this dissertation also discovered the processes of Personal Empowerment Awareness, Domestic Violence Awareness, and Parenting Empowerment, which can be used by the academia, think-tanks, and governments in order to evaluate the effect of CCTs on women's empowerment in the future. 


\section{Innovation}

The innovation presented with this dissertation consists in the in-depth qualitative research undertaken with both beneficiaries and non-beneficiaries of CCTs. In addition, this research was conducted in urban, semi-rural, and rural communities, providing a wide range of scenarios and showing how the effect of similar programmes can differ depending on the geographical area. Finally, by conducting a comparative case study research, similar CCTs could be analysed and their impact could be compared in order to extract best practices and to draw policy recommendations for other countries or organizations wanting to implement poverty reduction programmes with a gender approach.

\section{Schedule \& Implementation}

If the policy recommendations that this doctoral dissertation provides are followed, CCTs in Mexico and Brazil could include 1) access to education for the beneficiaries, 2) participation of the men in the programme, and 3) a link to productive opportunities or access to the labour market.

These changes in the structural social protection policies could make conditional cash transfer programmes more efficient and improve their cost-efficiency. The proposed plan for having the results of this dissertation disseminated widely is to provide the dissertation to the Ministry of Social Development in Mexico and to the Ministry for Social Development and to Combat Hunger in Brazil. Furthermore, to publish the essays in peer-reviewed journals directed to both academia and policy makers. In this way, the results may reach larger audiences. 


\section{Short Biography}

Patricia Silva is a Mexican national who joined the Maastricht Graduate School of Governance and UNU-MERIT as a PhD Fellow in September 2010. Previous to pursuing her $\mathrm{PhD}$, she was working for the German Agency for International Cooperation (GIZ) in the social protection department based in Eschborn, Germany, dealing with basic social protection access and best-practice transfer of conditional cash transfers in Latin America and South East Asia.

Patricia holds a BA in International Relations from El Colegio de México, Mexico, and an MA in Governance and Development from the Institute of Development Studies (IDS) at the University of Sussex, UK. In addition, she participated in the Managing Global Governance post-graduate programme from the German Development Institute (GDI) in Bonn and has undertaken research for El Colegio de México, the Mexican Ministry for Social Development (SEDESOL), the IDS, GDI, the Vietnamese Ministry for Labour, Invalids and Social Affairs (MOLISA) and the German Ministry for Economic Cooperation and Development (BMZ) in the areas of social policy, social protection, and gender.

Currently, Patricia lives in Haarlem with her husband Francis and their puppy Atlas. They enjoy travelling to faraway destinations, visiting friends and family in Mexico, cooking exotic cuisines, and spending afternoons on the beach. 


\section{Bibliography}

Adato, M., B. De la Brière, D. Mindek and A. Quisumbing. (2000). The Impact of PROGRESA on Women's Status and Intra-household Relations. Washington, D.C.: International Food Policy Research Institute.

Adato, M. (2004). Programas de transferencias monetarias condicionadas: beneficios y costos sociales. In J. Boltvinik and A. Damián (Eds.), La pobreza en México y el mundo. Realidades y desafíos. Mexico: Gobierno del Estado de Tamaulipas-Siglo XXI Editores.

Adato, M. and J. Hoddinott (Eds.) (2010). Conditional Cash Transfers in Latin America. Baltimore: John Hopkins University Press for IFPRI.

Adato, M., and T. Roopnaraine (2010). Women's status, gender relations, and conditional cash transfers. In M. Adato, and J. Hoddinott (Eds.), Conditional Cash Transfers in Latin America. Baltimore: John Hopkins University Press for IFPRI.

Agarwal, B. (1997). Bargaining and gender relations: Within and beyond the household. Feminist Economics 3(1), 1-51.

Alkire, S., and J. Foster (2007). Counting and multidimensional poverty measurement. OPHI Working Papers 7. Oxford: Oxford University.

Alonso, J., L.A. Aguilar and R. Lang (Eds.) (2002). El futuro del Estado social. Mexico: Universidad de Guadalajara-ITESO-Goethe Institut Guadalajara.

Alsop, R., N. Heinsohn and A. Somma (2005). Measuring empowerment: An analytic framework. In R. Alsop (Ed.), Power, Rights and Poverty: Concepts and Connections. Washington, D.C.: World Bank.

Alzúa, M.L., G. Cruces, and L. Ripani (2009) Labour Market Equilibrium and Conditional Cash Transfers. Experimental Evidence from Latin America. CEDLAS-UNLP.

Alzúa, M.L., G. Cruces, and L. Ripani (2013). Welfare programs and labour supply in developing countries: Experimental evidence from Latin America. Journal of Population Economics 26, 1255-1284.

Angelucci, M. and G. De Giorgi (2009). Indirect effects of an aid program: How do cash transfers affect ineligibles' consumption? American Economic Review 99(1): 486-508.

Apps, P.F. and R. Rees (1996). Labour supply, household production and intra-family welfare distribution. Journal of Public Economics 60(2), 199-219.

Arteaga Basurto, C. and S. Solís San Vicente (Eds.) (2001). La política social en la transición. Mexico City: UNAM-Escuela Nacional de Trabajo Social-Plaza y Valdés. 
Asian Development Bank (2002). Sociolegal Status of Women in Indonesia, Malaysia, Philippines, and Thailand. Manila: ADB.

Attanasio, O. and V. Lechene (2002). Testing of income pooling in household decisions. Review of Economic Dynamics 5(4), 720-748.

Attanasio, O., H. Low and V. Sanchez-Marcos (2008). Explaining changes in female labor supply in a life-cycle model, American Economic Review 98(4), 1517-52.

Aziz Nassif, A. (Ed.) (2003). México al inicio del siglo XXI, democracia, ciudadanía y desarrollo. Mexico City: CIESAS-Porrúa.

Barber, S. and P.J. Gertler (2008). The impact of Mexico's conditional cash transfer programme, Oportunidades, on birthweight. Tropical Medicine and International Health 13(11), 1405-1414.

Barber, S. and P.J. Gertler (2009). Empowering women to obtain high quality care: Evidence from an evaluation of Mexico's conditional cash transfer programme. Health Policy and Planning 24, 18-25.

Barbieri-Masini, E. (Ed.) (2009). Quality of human resources: Gender and indigenous peoples. Encyclopedia of Life Support Systems, Paris: UNESCO.

Barrientos, A. and J. DeJong (2004). Child Poverty and Cash Transfers. London: Childhood Poverty Research and Policy Center.

Barrientos, A. and J. DeJong (2006). Reducing child poverty with cash transfers: A sure thing? Development Policy Review 24(5), 537-552.

Barrientos, A. (2008). Social transfers and growth linkages. Good practice note and full report prepared for DFID and OECD Network on Poverty Reduction (POVNET) Task Team on Social Protection. Manchester: Brooks World Poverty Institute.

Barrientos, A. and D. Hulme (2009) Social protection for the poor and poorest in developing countries: Reflections on a quiet revolution. Oxford Development Studies 37(4), 439-456.

Basu, K. (2006). Gender and say: A model of household behaviour with endogenously determined balance of power. The Economic Journal 116, 558-580.

Batista, A. (1994). The situation of women in Latin America: Changing trends in the 1980s. Statistics and Economic Projections Division. ECLAC. New York: UN.

Batliwala, S. (1994). The meaning of women's empowerment: New concepts from action. In G. Sen, A. Germain and L. Chen, Population Policies Reconsidered: Health, Empowerment and Rights. Cambridge. MA.: Harvard University Press. 
Baulch, B. (2006). The New Poverty Agenda: A disputed consensus, IDS Bulletin 37(4), 82-90.

Becker, G. S. (1981). A Treatise on the Family. Harvard: Harvard University Press.

Behrman, J., S. W. Parker and P. Todd (2004). Evaluation of Oportunidades 2004 mediumterm effects of the Oportunidades Program package, including nutrition, on education of rural children age 0-8 in 1997. Technical Document Number 9. INSP (unpublished manuscript).

Behrman, J. (2010). The International Food Policy Research Institute (IFPRI) and the Mexican PROGRESA anti-poverty and human resource investment conditional cash transfer program. World Development 38(10), 1473-1485.

Behrman, J. and S. Parker (2010). The impacts of conditional cash transfers programs on education. In Adato and Hoddinott (Eds.), Conditional Cash Transfers in Latin America. Washington, D.C.: IFPRI.

Bennett, L. (2002). Using empowerment and social inclusion for pro-poor growth: A theory of social change. Background Paper for the Social Development Strategy Paper. Washington, D.C.: World Bank.

Bibars, I. (2001). Victims and Heroines: Women, Welfare and the Egyptian State. London: Zed.

Blaug, M. (1976). The empirical status of human capital theory: A slightly jaundiced survey. Journal of Economic Literature 14(3), 827-855.

Blumberg, B., D. Cooper and P. Schindler (2008). Business Research Methods (7th edition). London: McGraw-Hill.

BMZ (2001). Concept for the promotion of equal participation by women and men in the development process. Bonn: BMZ.

Boltvinik, J. (2004). Políticas focalizadas de combate a la pobreza en México. El Progresa/Oportunidades. In J. Boltvinik and A. Damián (Eds.), La pobreza en México y el mundo. Realidades y desafíos. Mexico: Gobierno del Estado de Tamaulipas-Siglo XXI Editores.

Boltvinik, J. and A. Damián (Eds.) (2004). La pobreza en México y el mundo. Realidades y desafíos. Mexico: Gobierno del Estado de Tamaulipas-Siglo XXI Editores, Mexico.

Bradshaw, S. (2008). From structural adjustment to social adjustment: A gendered analysis of conditional cash transfer programs in Mexico and Nicaragua. Global Social Policy 8, 188-207. 
Bradshaw, S. and A. Quiroz Viquez (2008). Women beneficiaries or women bearing the cost: A gendered analysis of the Red de Protección Social in Nicaragua. Development and Change 39(5), 23-44.

Britto, T. (2005). Recent trends in the development agenda of Latin America: an analysis of conditional cash transfers. Brasilia: Ministry of Social Development.

Britto, T. (2008). The emergence and popularity of conditional cash transfers in Latin America. In

A. Barrientos and D. Hulme (Eds.), Social Protection for the Poor and Poorest: Concepts, Policies and Politics. London: Palgrave Macmillan.

Brock, K., A. Cornwall and J. Gaventa (2001). Power, knowledge and political spaces in the framing of poverty policy. Working Paper 143. Brighton: IDS.

Browning, M., F. Bourguignon, P.-A. Chiappori and V. Lechene (1994). Incomes and outcomes: A structural model of intrahousehold allocation. Journal of Political Economy 102(6), 1067-1096.

Browning, M., P.-A. Chiappori and V. Lechene (2006). Collective and unitary models: A clarification. Review of Economics of the Household 4, 5-14.

Buvinic, M. and G. R. Gupta (1994). Targeting poor woman-headed households and womanmaintained families in developing countries: Views on a policy dilemma. Washington, D.C.: International Center for Research on Women and the Population Council.

Buvinic, M. and G. R. Gupta (1997). Female-headed households and female-maintained families: Are they worth targeting to reduce poverty in developing countries? Economic Development and Cultural Change 45(2), 259-80.

Calva, J. L. (2004). La economía mexicana en perspectiva. In J. Boltvinik and A. Damián (Eds.), La pobreza en México y el mundo. Realidades y desafíos. Mexico: Gobierno del Estado de Tamaulipas-Siglo XXI Editores.

Canto, M. (2003). Desarrollo social y sociedad civil: ¿un asunto político? In M. Gendreau and E. Valencia (Eds.), Hacia la transformación de la política social en México. Mexico: Universidad Iberoamericana Puebla-UDG-ITESO-UNICEF-INDESOL-SEDESOL.

Carter, M. and E. Katz (1997). Separate spheres and the conjugal contract: Understanding the impact of gender-biased development. In L. Haddad, J. Hoddinott and H. Aldermann, (Eds.), Intrahousehold Resource Allocation in Developing Countries: Methods, Models and Policies. Johns Hopkins University Press.

Carter, M. and C. Barrett (2006). The economics of poverty traps and persistent poverty: An asset-based approach. Journal of Development Studies 42(2), 178-199. 
Centre for the Future State (2005). Signposts to More Effective States: Responding to Governance Challenges in Developing Countries. Brighton: IDS.

CEPAL (2002). Panorama social de América Latina 2002-2003. Mexico City: CEPAL.

Chant, S. and M. Gutmann (2000). Mainstreaming Men into Gender and Development: Debates, Reflections and Experiences. Oxford: Oxfam.

Chant, S. (2007). Gender, Generation and Poverty: Exploring the 'Feminisation of Poverty' in Africa, Asia and Latin America. Cheltenham: Edward Elgar.

Chant, S. (2008). The "Feminisation of Poverty" and the "Feminisation" of anti- poverty programmes: room for revision? Journal of Development Studies 44 (2), 165-97.

Chant, S. and C. McIlwaine (2009). Geographies of Development in the 21st Century: An Introduction to the Global South. Cheltenham: Edward Elgar.

Chant, S. (Ed.) (2010). The International Handbook of Gender and Poverty. Concepts, Research, Policy. Cheltenham: Edward Elgar.

Charmes, J. and S. Wieringa (2003). Measuring women's empowerment: An assessment of the Gender-related Development Index and the Gender Empowerment Measure. Journal of Human Development 4, 419-435.

Chen, M. and S. Mahmud (1995). Assessing Change in Women's Lives: A Conceptual Framework. Dhaka: BRAC-ICDDR.

Chen, M. (2010). Informality, poverty and gender: Evidence from the Global South. In S. Chant (Ed.), The International Handbook of Gender and Poverty. Concepts, Research, Policy. Cheltenham: Edward Elgar.

Chiappori, P.-A. (1988). Rational household labor supply. Econometrica 56(1), 63-90.

Chiappori, P.-A. (1992). Collective labor supply and welfare. Journal of Political Economy 100(3), 437-467.

Chiappori, P.-A. and O. Donni (2009). Non unitary models of household behavior: A survey of literature. Working Paper 4603, Institute for the Study of Labor - IZA.

Chitolina, L., M. Foguel, and N. Aquino (2016). The impact of the expansion of the Bolsa Família Program on the time allocation of youths and their parents. Revista Brasileira de Economia 70(2), 183-202.

Coady, D. (2001). An evaluation of the distributional power of Progresa's cash transfers in Mexico. FCND Discussion Paper 117. Washington, D.C.: IFPRI. 
Coates, A. (2010). Multidimensional poverty measurement in Mexico and Central America: Incorporating rights and equality. In S. Chant (Ed.), The International Handbook of Gender and Poverty. Concepts, Research, Policy. Cheltenham: Edward Elgar.

Cohen, E. and R. Franco (Eds.) (2005). Gestión social: cómo lograr eficiencia e impacto en las políticas sociales. Mexico: CEPAL-Siglo XXI Editores.

Cohen, E. and R. Franco (Eds.) (2006). Transferencias con corresponsabilidad: una mirada Latinoamericana. Mexico City: FLACSO.

Collier, P. (1994). Gender aspects of labour allocation during structural adjustment: Theoretical framework and the Africa experience. In S. Horton, R. Kanbur and D. Mazumbur (Eds.), Labour Markets in an Era of Adjustment Vol. 1. Washington, D.C.: World Bank.

Comité Técnico para la Medición de la Pobreza (2002). Nota técnica para la medición de la pobreza con base en los resultados de la Encuesta Nacional de Ingresos y Gastos de los Hogares (ENIGH). Mexico City: INEGI.

CONEVAL (2014). Medición de la pobreza, Estados Unidos Mexicanos, 2014. Mexico City: CONEVAL. http://www.coneval.org.mx/Medicion/MP/PublishingImages/ Pobreza_2014.jpg

Cornwall, A. (2000). Beneficiary, Consumer, Citizen: Perspectives on Participation for Poverty Reduction. Stockholm: SIDA.

Cornwall, A. and K. Brock (2005). Beyond buzzwords: Poverty reduction, participation and empowerment in development policy. Overarching Concerns Programme Paper 10. Geneva: UNRISD.

Cornwall, A. and J. Gaventa (2001). From users and choosers to makers and shapers: Repositioning participation in social policy. Working Paper 127. Brighton: IDS.

Dávila, L. (2016). Cómo funciona Prospera? Mejores prácticas en la implementación de programas de transferencias monetarias condicionadas en América Latina y el Caribe. División de Protección Social y Salud Nota Técnica N. IDB-TN-971, Washington, D.C.: BID.

De Brauw, A., D. Gilligan, J. Hoddinott and S. Roy (2014). The impact of Bolsa Família on women's decision-making power. World Development, 59: 487-504.

Del Campo, S., T. Hamada, G. Barbiroli, S. Sassen, E. Barbieri-Masini, P.N. Nkwi, O. Sichone, and A. Momoh (2010). Social and Economic Development VII. Encyclopedia of Life Support Systems. Paris: UNESCO.

Deere, C., G. Alvarado, and J. Twyman (2012). Gender inequality in asset ownership in Latin America: Female owners vs. household heads. Development and Change 43(2), 505-530. 
De Neubourg, C. and C. Weigand (2000). Social policy as social risk management innovation. The European Journal of Social Sciences 13(4), 401-412.

De Neubourg, C., J. Chai, M. de Milliano, I. Plavgo, and Z. Wei (2012a). Cross-country MODA study: Multiple Overlapping Deprivation Analysis (MODA) - Technical note. Innocenti Working Paper 2012(5). Florence: UNICEF Office of Research.

De Neubourg, C., J. Chai, M. de Milliano, I. Plavgo, and Z. Wei (2012b), Step-by-step guidelines to MODA - Multiple Overlapping Deprivation Analysis. Innocenti Working Paper 2012(10). Florence: UNICEF Office of Research.

De Neubourg C., M. De Milliano and I. Plavgo (2014). Lost (in) dimensions: Consolidating progress in multidimensional poverty research. Innocenti Working Paper 2014 (4). Florence: UNICEF Office of Research.

Devereux, S. (1999). Targeting transfers: Innovative solutions to familiar problems, IDS Bulletin 30(2), 61-74.

Devereux, S. and M. Moore (Eds.) (1999). Nationalising the anti-poverty agenda? IDS Bulletin 30(2).

Devereux, S. (2002). Social protection for the poor: Lessons from recent international experience. IDS Working Paper 142. Brighton: IDS.

Devereux, S. and A. Solórzano (2016). Broadening social protection thinking. IDS Bulletin $47(2), 63-76$.

DFID (2005a). Partnerships for poverty reduction: rethinking conditionality, A UK policy paper. London: DFID.

DFID (2005b). Social transfers and chronic poverty: Emerging evidence and the challenge ahead, $A$ DFID practice paper. London: DFID.

Diaz, J. and S. Handa (2005). An assessment of propensity score matching as a nonexperimental impact estimator: Evidence from Mexico's PROGRESA Program. Journal of Human Resources 41(2), 319-345.

Diener, E. and Biswas-Diener, R. (2005). Psychological empowerment and subjective wellbeing. In D. Narayan (Ed.). Measuring Empowerment: Cross-disciplinary Perspectives. Washington, D.C.: World Bank.

Dollar, D. and R. Gatti (1999). Gender inequality, income, and growth: Are good times good for women? Policy Research Report on Gender and Development, Working Paper 1. World Bank, Washington, D.C.: World Bank. 
Doss, C. (2013). Intrahousehold bargaining and resource allocation in developing countries. Policy Research Working Paper 6337. Washington, D.C.: World Bank.

Dresser, D. (1992). Bringing the Poor Back in: Poverty Alleviation and Regime Legitimacy in Mexico. California: University of California.

ECLAC (1995). Desenvolvimiento de los procesos de integración en América Latina y el Caribe. Santiago: ECLAC.

Escobar, A. (2003). Progresa y los nuevos paradigmas de la acción social del estado en México. In M. Gendreau and E. Valencia (Eds.), Hacia la transformación de la política social en México. Mexico: Universidad Iberoamericana Puebla-UdG-ITESO-UNICEF-INDESOLSEDESOL.

Escobar, A. (2004). La evaluación cualitativa del Programa de Desarrollo Humano Oportunidades 2001-2002 (expansión a pequeñas ciudades). Reflexiones y resultados. In J. Boltvinik and A. Damián (Eds.), La pobreza en México y el mundo. Realidades y desafíos. Mexico: Gobierno del Estado de Tamaulipas-Siglo XXI Editores.

Escobar Latapí, A. and M. González de la Rocha (2009). Girls, mothers and poverty reduction in Mexico: Evaluating Progresa-Oportunidades. In S. Razavi (Ed.). The Gendered Impacts of Liberalization: Towards "Embedded Liberalism"? New York: Routledge.

Esping-Andersen, G. (1990). The Three Worlds of Welfare Capitalism. Oxford: University of Oxford Press.

Espinosa, G. (2006). La participación en la actividad económica de las mujeres de Oportunidades y su relación con la corresponsabilidad de éste y otros programas sociales. Mexico City: El Colegio de México.

Evans, P. (1992). The state as problem and solution: Predation, embedded autonomy, and structural change. In S. Haggard and R. Kaufman (Eds.), The Politics of Economic Adjustment. Princeton: University Press.

Eyben, R. and L. Turquet (Eds.) (2014). Feminists in Development Organisations: Change from the Margins. Rugby: Practical Action Publishing.

Fafchamps, M., and A. Quisumbing (2002). Control and ownership of assets within rural Ethiopian households. The Journal of Development Studies 38(6), 47-82.

FAO (2006). Policy Responses to High Food Prices in Latin America and the Caribbean. Country Case Studies. Rome: FAO.

FAO (2011). The State of Food and Agriculture 2010-11: Women in Agriculture-Closing the Gender Gap for Development. Rome: FAO. 
Ferro, A. and A. Nicolella (2007). The impact of conditional cash transfer programs on household work decisions in Brazil. FEA-RP Working Paper Series. Monte Alegre: FEARP.

Fernandez, F. and V. Saldarriaga (2014). Do benefit recipients change their labor supply after receiving the cash transfer? Evidence from the Peruvian Juntos program. IZA Journal of Labor and Development 3(2).

Fiszbein, A., N. Schady, F. Ferreira, M. Grosh, N. Kelleher, P. Olinto, and E. Skoufias (2009). Conditional cash transfers: Reducing present and future poverty. World Bank Policy Research Report. Washington, D.C.: World Bank.

Foguel M. and R.P. Barros (2008). The effects of conditional cash transfer programmes on adult labour supply: an empirical analysis using a time-series-cross-section sample of Brazilian municipalities. Paper presented at XXXVII Encontro Nacional De Economia. Foz do Iguaçu: Brazil.

Foguel M. and R.P. Barros (2010). The effects of conditional cash transfer programmes on adult labour supply: an empirical analysis using a time-series-cross-section sample of Brazilian municipalities. Estudios Economicos 40(2), 259-283.

Fox, J. (1992). The Politics of Food in Mexico: State Power and Social Mobilisation. Ithaca: Cornwell University Press.

Fox, J. (1994). The difficult transition from clientelism to citizenship: Lessons from Mexico. World Politics 46(2), 151-184.

Frankenberg, E. and D. Thomas (2003). Household decisions, gender and development: Measuring power. In A. Quisumbing (Ed.), Household Decisions, Gender and Development: A Synthesis of Recent Research. Washington, D.C.: International Food Policy Research Institute (IFPRI).

Free, J., K. Kriz and J. Konecnik (2014). Harvesting hardships: Educators' views on the challenged of migrant students and their consequences on education. Children and Youth Services Review 47, 187-197. Emmanuel College, Boston.

Freire, P. (1970). Pedagogy of the Oppressed. New York: Herder and Herder.

Gallardo, R. and J. Osorio (Eds.) (1998). Los rostros de la pobreza. El debate, tomo 1. Mexico City: ITESO-Universidad Iberoamericana.

García-Junco Machado, D. (1997). Confronting Poverty in Mexico. An Overview of Social Policy. Mexico City: CIDE.

García, X.M. and S.-A. Way (2003). Winning spaces: Participatory methodologies in rural processes in Mexico. Pathways to Participation Series Working Paper 180. Brighton: IDS. 
Gazola Hellmann, A. (2015). How does Bolsa Família work? Best practices in the implementation of conditional cash transfer programs in Latin America and the Caribbean. Social Protection and Health Division Technical Note N. IDB-TN-856. Washington, D.C.: IDB.

Gendreau, M. and E. Valencia (Eds.) (2003). Hacia la transformación de la política social en México. Mexico: Universidad Iberoamericana Puebla-UdG-ITESO-UNICEF-INDESOLSEDESOL.

GIZ (2009). Steps for action to promote gender equality. Programme Promoting Gender Equality and Women's Right. Eschborn: GIZ.

Glick, P. and S. Fiske (1999). The ambivalence toward men inventory: Differentiating hostile and benevolent beliefs about men. Psychology of Women Quarterly 23, 519-536.

Goetz, A.-M. and J. Gaventa (2001). From consultation to influence: Bringing citizen voice and client focus into service delivery. Working Paper 138. Brighton: IDS.

Goetz, A.-M. (2003). Women's political effectiveness: A conceptual framework. In A.-M. Goetz and S. Hassim, No Shortcuts to Power: African Women in Politics and Policy Making. London: Zed Books.

Goldin, C. (1994). The U-shaped females labour force function in economic development and economic history. Working Paper 4707. Massachusetts: National Bureau of Economic Research.

Gómez de Léon, J. and S. Parker (1999). The well-being of female-headed households. Paper presented at the 1999 Annual Meeting of the Population Association of America. Los Angeles.

Gómez-Hermosillo, R. (2003). Los retos del Progresa en la nueva política social. In M. Gendreau and E. Valencia (Eds.), Hacia la transformación de la política social en México. Mexico: Universidad Iberoamericana Puebla-UdG-ITESO-UNICEF-INDESOL-SEDESOL.

Grabe, S. (2012). An empirical examination of women's empowerment and transformative change in the context of international development. American Journal of Community Psychology 49(1), 233-245.

Grindle, M. (2000). The social agenda and the politics of reform in Latin America. In A.M. Garland and J.S. Tul-chin (Eds.). Social Development in Latin America. The Politics of Reform. Boulder: Lynne Riener Publishers.

Grown, C. (2006) Quick impact initiatives for gender equality: A menu of options. Levy Economics Institute Working Paper 462. Annandale-on-Hudson: Bard College. 
Haddad, L., J. Hoddinott, and H. Alderman (1994). Intrahousehold resource allocation: An overview. Policy Research Working Paper 1255. Washington, D.C.: World Bank.

Haddad, L., J. Hoddinott, and H. Alderman (1998). Intra-household Resource Allocation in Developing Countries: Models, Methods and Policies. Baltimore: Johns Hopkins University Press.

Handa, S. and B. Davis (2006). The experience of conditional cash transfers in Latin America and the Caribbean. Development Policy Review 24(5), 513-536.

Handa, S., A. Peterman, B. Davis, and M. Stampini (2009). Opening up Pandora's box: The effect of gender targeting and conditionality on household spending behavior in Mexico's Progresa programme. World Development 37(6), 1129-1142.

Hall, A. (2008). Brazil's Bolsa Família: A double-edged sword? Development and Change 39(5), 799-822.

Hardiman, M. and J. Midgley (1986). The Social Dimensions of Development: Social Policy and Planning in the Third World. London: Sage.

Hasan, A. (2010). Time allocation in rural households: the indirect effects of conditional cash transfer programs. Policy Research Working Paper 5256. Washington, D.C.: World Bank.

Herzog, K. (2011). Effective poverty reduction and empowering women: a win-win situation? CCTs in Latin America. Discussion Paper on Social Protection 12. Eschborn: GIZ.

Hoddinott, J., and L. Haddad (1995). Does female income share influence household expenditure? Evidence from Côte d'Ivoire. Oxford Bulletin of Economics and Statistics 57(1), 77-96.

Holmes, R. and A. Barrientos (2009). Child Poverty: A Role for Cash Transfers? Regional and Thematic Report. London: ODI.

Holmes, R. and N. Jones (2010). Rethinking social protection using a gender lens. Working Paper 320. London: ODI.

Holmes, R., N. Jones, R. Vargas and F. Veras (2010). Cash Transfers and Gendered Risks and Vulnerabilities: Lessons from Latin America. London: ODI.

Holzmann, R. and O. Jorgensen (2000). Manejo social del riesgo: un nuevo marco conceptual para la protección social y más allá, Working Paper 6. Washington, D.C.: World Bank.

Horace, W. and R. Oaxaca (2001). Inter-industry wage differentials and the gender wage gap: An identification problem. Industrial and Labour Relations Review 54(3), 611-8. 
Houtzager, P. and M. Moore (Eds.) (2005). Changing Paths, International Development and the New Politics of Inclusions. Michigan: University of Michigan Press.

ILO (2016). http://www.social-protection.org/gimi/gess/ShowWiki.action?wiki. wikiId $=3044$

IMF (1995). Social Dimension of the IMF's Policy Dialogue. Washington, D.C.: IMF.

Iversen, V. (2003). Intra-household inequality: A challenge for the capability approach? Feminist Economics 9 (2-3), 93-115.

Jackson, C. (1996). Rescuing gender from the poverty trap. World Development 24(3), 489-504.

Jackson, C. (1997) Post poverty, gender and development. IDS Bulletin 28(3), 145-55.

Jejeebhoy, S. and Z. Sathar (2001). Women's autonomy in India and Pakistan: The influence of religion and region. Population and Development Review 27(4), 687-921.

Kabeer, N. (1999). Resources, agency and achievements: Reflections on the measurement of women's empowerment. Development and Change 30, 435-464.

Kabeer, N. (2003). Gender Mainstreaming in Poverty Eradication and the Millennium Development Goals: A Handbook for Policymakers and Other Stakeholders. Ottawa: International Development Research Centre.

Kabeer, N. (2005). Is microfinance a 'magic bullet' for women's empowerment? Analysis of findings from South Asia. Economic and Political Weekly October 2005, 4709-4718.

Kabeer, N. (2008). Mainstreaming Gender in Social Protection for the Informal Economy. London: Commonwealth Secretariat.

Kabeer, N., C. Piza and L. Taylor (2012). What are the economic impacts of conditional cash transfer programmes? A systematic review of the evidence. Technical report. London: EPPICentre, University of London.

Katz, E. (1997). The intra-household economics of voice and exit. Feminist Economics 3(3), 2546.

Khan, A. (2014). Paid work as a pathway of empowerment: Pakistan's Lady Health Worker Programme. In A. Cornwall and J. Edwards (Eds.), Feminisms, Empowerment and Development: Changing Women's Lives. London: Zed Books.

Kishor, S. and K. Gupta (2004). Women's empowerment in India. In I. Rajan and K. James (Eds.), Demographic Change Health Inequality and Human Development in India. Hyderabad: CESS. 
Klasen, S. (2006). Pro-poor growth and gender inequality. In L. Menkhoff (Ed.), Pro-Poor Growth: Policy and Evidence. Berlin: Duncker \& Humblot.

Klasen, S., T. Lechtenfeld, and F. Povel (2015). A feminization of vulnerability? Female headship, poverty, and vulnerability in Thailand and Vietnam, World Development 71, 3653.

Kurtz, M. J. (2005). The boundaries of antipoverty policy. Economic ideas, political coalitions, and the structure of social provision in Chile and Mexico. In P. Houtzager and M. Moore (Eds.), Changing Paths, International Development and the New Politics of Inclusion. Michigan: University of Michigan Press.

Lampietti, J. and L. Stalker (2000). Consumption expenditure and female poverty: A review of the evidence. Policy Research Report on Gender and Development, Working Paper Series 11. Washington, D.C.: World Bank.

Lehmann, C. (2010). Benefiting without receiving money? Externalities of conditional cash transfer programmes on schooling, health and the village economy. Policy Research Brief 13. Brasilia: International Policy Centre for Inclusive Growth.

Lindert, K., A. Linder, J. Hobbs, B. and De la Brière (2007). The nuts and bolts of Brazil's Bolsa Família program: Implementing conditional cast transfers in a decentralized context. World Bank Social Protection Discussion Paper 709. Washington, D.C.: World Bank.

Lipton, M. and S. Maxwell (1992). The New Poverty Agenda: An overview. IDS Discussion Paper 306. Brighton: IDS.

López, M. and V. Salles (Eds.) (2006). El Programa Oportunidades examinado desde el género. Mexico City: Oportunidades-El Colegio de México-UNIFEM.

Lundberg, S., and R. Pollak (1994). Noncooperative bargaining models of marriage. American Economic Review 84(2), 132-137.

Lundberg, S., and R. Pollak (1996). Bargaining and distribution in marriage. Journal of Economic Perspectives 10(4), 139-158.

Lundberg, S., and R. Pollak (2003). Efficiency in marriage. Review of Economics of the Household 1(3), 153-167.

Lundberg, S. and E. Rose (2007). Parenthood and the earnings of married men and women. Labour Economics 7(6), 689-710.

Mader, K. and A. Schneebaum (2013). The gendered nature of intra-household decision making in and across Europe. Department of Economics Working Papers WUWP 157. Vienna: University of Economics. 
Mahmud, S., N. Shah, and S. Becker (2012). Measurement of women's empowerment in rural Bangladesh. World Development 40(3), 610-619.

Maldonado, I., M. Nájera and A. Segovia (2006). Efectos del Programa Oportunidades en las relaciones de pareja y familiares. In M. López and V. Salles (Eds.), El Programa Oportunidades examinado desde el género. Mexico City: Programa de Desarrollo Oportunidades.

Malhotra, A. and M. Mather (1997). Do schooling and work empower women in developing countries? Gender and domestic decisions in Sri Lanka. Sociological Forum 12(4), 599-630.

Malhotra, A., S. Schuler and C. Bonder (2002). Measuring Women's Empowerment as a Variable in International Development. Washington, D.C.: World Bank.

Maluccio, J. (2007). The impact of conditional cash transfers in Nicaragua on consumption, productive investments, and labor allocation. Agricultural and Development Economics Division, ESA Working Paper No. 07-11. UN's Food and Agriculture Organization.

Manser, M. and M. Brown (1980). Marriage and household decision-making: A bargaining analysis. International Economic Review 21(1), 31-44.

Mason, K and H. Smith (2000). Husbands' versus wives' fertility goals and use of contraception: The influence of gender context in five Asian countries. Demography 37(3), 299-311.

Maxwell, S. (2003). Heaven or hubris: Reflections on the new "New Poverty Agenda". Development Policy Review 21, 15-35.

Maxwell, J. (2005). Qualitative Research Design. An Interactive Approach. Thousand Oaks, CA: Sage Publications.

Mayo, M. and G. Craig (1995). Community participation and empowerment: The human face of structural adjustment or tools for democratic transformation. In G. Craig and M. Mayo, Community Empowerment: A Reader in Participation and Development. London: Zed Books.

Mayoux, L., (2006). Women's empowerment through sustainable micro-finance: Rethinking "best practice." Discussion Paper, Gender and Micro-finance.

McElroy, M. and M. Horney (1981). Nash-bargained decisions: Towards a generalization of the theory of demand. International Economic Review 22, 333-349.

McElroy, M.B. (1990). The empirical content of Nash-bargained household behavior. Journal of Human Resources 25(4), 559-583. 
Medeiros, M. and J. Costa (2008). Is there a feminization of poverty in Latin America? World Development 36(1), 115-27.

Medeiros, M., T. Britto and F. Soares (2008). Targeted cash transfer programmes in Brazil: BPC and the Bolsa Família. IPC Working Paper 48. Brasilia: International Poverty Centre.

Middlebrook, K.J. and E. Zepeda (Eds.) (2003). Confronting Development: Assessing Mexico's Economic and Social Policy Challenges. Stanford: Standford University.

Midgley, J. (1995). Social Development. The Development Perspective in Social Welfare. London: Sage.

Miles, M.B. and A.M. Huberman (1994). Qualitative Data Analysis. Thousand Oaks, CA: Sage.

Moghadam, V. (2005). The feminisations of poverty and women's human rights. SHS Papers in Women's Studies and Gender Research 2. Paris: UNESCO.

Molyneux, M. (2006). Mothers at the service of the new poverty agenda: Progresa/Oportunidades, Mexico's conditional transfer programme. Journal of Social Policy and Administration 40(4), 425-49.

Molyneux, M. (2007a). Two cheers for CCTs. IDS Bulletin 38(3), 69-74.

Molyneux, M. (2007b). Change and continuity in social protection in Latin America: Mothers at the service of the state? Gender and Development Programme Paper Number 1. Geneva: UNRISD.

Molyneux, M. (2010). Conditional Cash Transfers: A "Pathway to Women's Empowerment"? Pathway Papers.

Moser, C. (1992). From Residual Welfare to Compensatory Measures: The Changing Agenda of Social Policy in Developing Countries. Brighton: IDS.

Moser, C. (1998). The asset vulnerability framework: Reassessing urban poverty reduction strategies. World Development 26 (1), 1-19.

Narayan, D. (Ed.) (2005). Measuring Empowerment. Cross-Disciplinary Perspectives. Washington D.C.: World Bank.

Nash, J. (1950). The bargaining problem. Econometrica 18(2). 155-162.

Nigenda, G. and L.M. González-Robledo (2005) Lessons offered by Latin American cash transfer programmes, Mexico's Oportunidades and Nicaragua's SPN. Implications for African countries. London: DFID. 
Novella, R., L. Ripani, G. Cruces and M.L. Alzúa (2012). Conditional cash transfers, female bargaining power and parental labour supply. IDB Working Paper Series No. IDW-WP368.

OECD (2009). What are equivalence scales? Long Abstract. Social Policy Division. Paris: OECD.

OECD (2014). Social expenditure update, November 2014. Directorate for Employment, Labour and Social Affairs. Paris: OECD.

Oliveira, A.M.H.C. de (2005). An evaluation of the Bolsa Família programme in Brazil: expenditures, education and labor outcomes. CEDEPLAR Working Paper.

Oportunidades (2002). Resumen ejecutivo de la evaluación externa del Programa de Desarrollo Humano Oportunidades. Mexico City: Sedesol-SEP-SS-SHCP-INSP-CIESAS.

Oportunidades (2003). Programa Institucional Oportunidades 2002-2006. Mexico City: Sedesol.

Oportunidades (2006). Oportunidades, Un programa de resultados. Mexico City: Sedesol.

Osmani, L. (2007). A breakthrough in women's bargaining power: The impact of microcredit. International of International Development 19, 695-716.

Pagán, J.A. and S.M. Sánchez (2000). Gender differences in labour market decisions: Evidence from rural Mexico. Economic Development and Cultural Change 48( 3), 619-637.

Parker, S. and E. Skoufias (2000). The impact of PROGRESA on work, leisure, and time allocation. Washington, D.C.: International Food Policy Research Institute.

Pearce, D. (1978). The feminization of poverty: Women, work and welfare. Urban and Social Change Review 11, 28-36.

Pedrozo, J. (2010). Efeitos de elegibilidade e condicionalidade do programa Bolsa Família sobre a alocacao de tempo dos membros do domocílio. PhD Thesis. Sao Paulo: Sao Paulo School of Economics.

Perkins, D. and M. Zimmerman (1995). Empowerment theory, research, and application. American Journal of Community Psychology 23(5), 569-79.

Pero, V. and D. Szerman (2005). The New Generation of Social Programs in Brazil (First Draft). Washington, D.C.: IFPRI.

Pieterse, J.N. (2001). Development Theory: Deconstructions/Reconstructions. London: Sage Publications.

Pollak, R. (1985). A transaction cost approach to families and households. Journal of Economic Literature 23, 581-608. 
Pollak, R. (1993). Separate spheres bargaining and the marriage market. Journal of Political Economy, 101(6), 988-1010.

Pratto, F. (1996). Sexual politics: The gender gap in the bedroom, the cupboard, and the cabinet. In D. Buss and N. Malamuth (Eds.), Sex, Power, and Conflict. New York: Oxford University Press.

Presidencia de la República (2006). Plan Nacional de Desarrollo 2006-2012. Mexico City: Presidencia de la República.

Progresa (2000a) ¿Está dando buenos resultados Progresa? Informe de los resultados de una evaluación realizada por el IFPRI. Mexico City: Sedesol-Progresa-IFPRI.

Progresa (2000b) Más oportunidades para las familias pobres, Evaluación de resultados del Programa de Educación, Salud y Alimentación, Aspectos operativos del Programa 2000. Mexico City: Sedesol.

Progresa (2001). Términos de referencia para la evaluación externa del Programa en reglas de operación. Mexico City: Sedesol.

Quisumbing, A., and J. Maluccio (1999). Intrahousehold allocation and gender relations: New empirical evidence. Policy Research Report on Gender and Development Working Paper Series 2. Washington, D.C.: World Bank.

Quisumbing, A. and B. De la Brière (2000). Women's assets and intrahousehold allocation in rural Bangladesh: Testing measures of bargaining power. Washington, D.C.: IFPRI.

Quisumbing, A. and J. Maluccio (2000). Intra-household allocation and gender relations: New empirical evidence from four developing countries. Food Consumption and Nutrition Division Discussion Paper 84. Washington, D.C.: IFPRI.

Quisumbing, A., and J. Maluccio (2003). Resources at marriage and intrahousehold allocation: Evidence from Bangladesh, Ethiopia, Indonesia, and South Africa. Oxford Bulletin of Economics and Statistics 65(3), 283-327.

Quisumbing, A. (2010). Gender and household decision-making in developing countries: A review of evidence. In S. Chant (Ed.), The International Handbook of Gender and Poverty: Concepts, Research, Policy. Cheltenham: Edward Elgar.

Ramful N. and C. de Neubourg (2017). Estimating multidimensional poverty among women; using an adjusted Multiple Overlapping Deprivation Analysis. SPRI Research Notes 2017 - 4 .

Rangel, M. (2005). Alimony rights and intrahousehold allocation of resources: Evidence from Brazil. Working Paper 505. Chicago: Harris School of Public Policy Studies, University of Chicago. 
Rao, V. (1997). Wife-beating in rural South India: A qualitative and econometric analysis. Social Science and Medicine 44(8), 1169-1180.

Rappaport, J. (1987). Terms of empowerment/exemplars of prevention: Toward a theory for community psychology. American Journal of Community Psychology 15(2), 121-148.

Ravallion, M. (1992). Poverty comparisons: A guide to concepts and methods. Living Standards Measurement Study Working Paper 88. Washington, D.C.: World Bank.

Rawlings, L. and G. Rubio (2003). Evaluating the impact of conditional cash transfer programs: Lessons from Latin America. World Bank Policy Research Working Paper 3119. Washington, D.C.: World Bank.

Rawlings, L. and G. Rubio (2005). Evaluating the impact of conditional cash transfer programs. The World Bank Research Observer20(1), 29-55.

Razavi, S. (2009). The gendered impacts of liberalization. Towards "embedded liberalism"? In S. Razavi (Ed.). The Gendered Impacts of Liberalization. Towards "Embedded Liberalism"? New York: Routledge.

Rivera, L., B. Hernández and R. Castro (2005). Asociación entre la violencia de pareja contra las mujeres urbanas en pobreza extrema e incorporación al Programa de Desarollo Humano Oportunidades. Mexico City: El Colegio de México.

Rodenberg, B. (2004). Gender and poverty reduction: New conceptual approaches in international development cooperation. Reports and Working Papers 4/2004. Bonn: German Development Institute.

Rowlands, J. (1998). A word of the times, but what does it mean? Empowerment in the discourse and practice of development. In A. Afshar (Ed.), Women and Empowerment: Illustrations from the Third World. New York: St. Martin's Press.

Rubio, M. (2002). The Impact of Progresa on Household Time Allocation. Mimeo.

Rubio Herrera, A. (2009). Mujeres mayas en el sur de Yucatán y su participación en una organización productiva. Tesis de Maestría. Merida: Instituto Politécnico Nacional.

Sabates-Wheeler, R. and N. Kabeer (2003). Gender equality and the extension of social protection, ESS Paper 16. Geneva: ILO.

Samson, M., I. van Niekerk, and K. Mac Quene (2006). Designing and Implementing Social Cash Transfer Programmes. Capetown: EFPRI.

Say, L., D. Chou, A. Gemmill, O. Tuncalp, A. Moller, J. Daniels, A.M. Gulmezoglu, M. Temmerman and L. Alkema (2014). Global causes of maternal death: a WHO systematic analysis. The Lancet Global Health 2, 323-333. 
Schady, N. and J. Rosero (2008). Are cash transfers made to women spent like other sources of income? Economic Letters 101, 246-248.

Secretaría de Desarrollo Social (Sedesol) (2002a). Así se construye Oportunidades. Informe 2002. Mexico City: Sedesol.

Sedesol (2002b). Estrategias de la política social. Mexico City: Sedesol.

Sedesol (2002c). Programa Nacional de Desarrollo 2001-2006. Superación de la pobreza: una tarea Contigo. Mexico City: Sedesol.

Sedesol (2003). Medición del Desarrollo, México 2000-2002. Mexico City: Sedesol.

Sen, A. (1985). Commodities and Capabilites. Amsterdam: North Holland.

Sen, A. (1990). Gender and cooperative conflicts. In I. Tinker (Ed.), Persistent Inequalities: Women and World Development. Oxford: Oxford University Press.

Sen, A. (1999). Development as Freedom. Oxford: Oxford University Press.

Sen, G. (2008). Poverty as a gendered experience: The policy implications. Poverty in Focus $13,6-7$.

Sen, G., A. Iyer and C. Mukherjee (2009). A methodology to analyse the intersections of social inequalities in health. Journal of Human Development and Capabilities 10(3), 397-415.

Sen, G. (2010). Poor households or poor women: Is there a difference? In S. Chant (Ed.), The International Handbook of Gender and Poverty: Concepts, Research, Policy. Cheltenham: Edward Elgar.

Sholkamy, H. (2011). How can social protection provide social justice for women? Pathways Policy Paper, October. Brighton: Pathways of Women's Empowerment.

Sholkamy, H. (2014). Steady money, state support and respect can equal women's empowerment in Egypt. In A. Cornwall and J. Edwards (Eds.), Feminisms, Empowerment and Development: Changing Women's Lives. London: Zed Books.

Silva, P. (2005). Los programas sociales de combate a la pobreza en México, 1988-2006: Pronasol, Progresa y Oportunidades. BA Dissertation. Mexico City: El Colegio de México.

Silva, P. (2006). Collective Action in Poverty Reduction Programmes: Lessons from the Progresa and Oportunidades Programmes in Mexico. MA Dissertation. Brighton: IDS.

Silva, P. (2007). Balancing the Agenda: Are Conditional Cash Transfer Programmes with a Gender Approach Having an Impact on Women's Empowerment? Lessons from the Oportunidades Programme in Mexico. Final Study. Bonn: German Development Institute. 
Silva, P. (2008). Mission (Im)possible? Getting CCTs to break the intergenerational poverty cycle. Lessons from Mexico and El Salvador. In V. Andersson and S. Christensen (Eds.), New Latin American Development Strategies in a Changing International Economic and Political Context. Development Research Series, Occasional Paper 7. Aalborg: University of Aalborg.

Simons, H. (2009). Case Study Research in Practice. Thousand Oaks, CA: Sage.

Skoufias, E. (2006). Progresa y su efecto sobre el bienestar de las familias rurales de México. Washington, D.C.: IFPRI.

Skoufias, E. and V. Di Maro (2008). Conditional cash transfers, adult work incentives, and poverty. Journal of Development Studies 44(7), 935-960.

Skoufias, E., M. Unar and T. González-Cossio (2008). The impacts of cash and in-kind transfers on consumption and labor supply: Experimental evidence from rural Mexico. Policy Research Working Paper 4778. Washington, D.C.: World Bank.

Smith, B. (2005). State-building. In P. Burnell and V. Randall (Eds.), Politics in the Developing World. Oxford: Oxford University Press.

Soares, S., R. Guerreiro, F. Veras Soares, M. Medeiros and E. Zepeda (2007). Conditional cash transfers in Brazil, Chile and Mexico: Impacts upon inequality. Working Paper 35. Brasilia: IPC.

Soares, F., R. Ribas and R. Osorio (2007). Evaluating the impact of Brazil's Bolsa Família: Cash transfer programmes in comparative perspective. IPC Evaluation Note 1. Brasilia: IPC.

Soares, S. (2012). Bolsa Família, its design, its impact and possibilities for the future. Working Paper 89. Brasilia: IPC.

Son, H. (2008). Conditional cash transfer programs: An effective tool for poverty alleviation? ERD Policy Brief Series 51. Manila: Asian Development Bank.

Stake, R. (1995). The art of case study research. Thousand Oaks, CA: Sage.

Suarez, M., M. Libardoni, M. Texeira, A. Cleaver, S. Riberiro and W. da Silva (2006). The Bolsa Familia Programme and the tackling of gender inequalities: The challenge of promoting the re-ordering of the domestic space and women's access to the public space. Report for the Brazilian Ministry of Social Development and Fight against Hunger (MDS) and DFID. Brasilia: MDS.

Sykes, J., K. Kriz, K. Edin, and S. Halpern-Meekin (2015). Dignity and dreams: What the Earned Income Tax Credit (EITC) means to low-income families. American Sociological Review 80(2), 243-267. 
Szirmai, A. (2015). Socio-Economic Development, Second Edition. Cambridge: Cambridge University Press.

Tavares, P.A. (2010). Efeito do programa Bolsa Família sobre a oferta de trabalho das mães. Revista Economia e Sociedade 19 (3), 613-635.

Teixeira, C.G. (2010). A heterogeneity analysis of the Bolsa Família programme: Effect on men and women's work supply. Working Paper 61. Brasilia: IPC - UNDP.

Tendler, J. (1997). Good Government in the Tropics. Baltimore: John Hopkins University Press.

Thakur, S., C. Arnold and T. Johnson (2009). Gender and Social Protection, Promoting Pro-Poor Growth: Social Protection. Paris: OECD.

Thomas, D. (1990). Intra-household resource allocation: An inferential approach. The Journal of Human Resources 25(4), 635-664.

Thomas, D. (1994). Like father, like son; like mother, like daughter: Parental resources and child height. The Journal of Human Resources 29(4), 950-988.

Thomas, D. (1997). Incomes, expenditures and health outcomes: Evidence on intrahousehold allocation. In L. Haddad, J. Hoddinott, and H. Alderman (Eds.), Intrahousehold Resource Allocation in Developing Countries. Baltimore: Johns Hopkins University Press for IFPRI.

Tomasevski, K. (1993). Women and Human Rights. London: Zed Books.

Toye, J. (1999). Ideas, doctrines and history: Nationalising the anti-poverty agenda. IDS Bulletin 30(2), 6-12.

United Nations (UN) (1995). Report of the World Summit for Social Development. March 6-12, 1995.

UN (1996). Report of the Fourth World Conference on Women. Beijing 4-15 September 1995. New York: UN.

UN (2001). Governance, Poverty Reduction and Gender Equality. Workshop Report. 23-25 April 2001.

Vienna: UN-OECD/DAC.

UN (2010). Achieving Gender Equality, Women's Empowerment and Strengthening Development Cooperation. Department of Economic and Social Affairs. New York: UN.

United Nations Development Programme (UNDP) (1990). Human Development Report 1990. Oxford: Oxford University Press. 
UNDP (2003). Millennium Development Goals. National Reports: A Look through a Gender Lens. New York: UNDP.

UNDP (2006). Human Development Report - Beyond Scarcity: Power, Poverty and the Global Water Crisis. New York: UNDP.

Valencia Lomelí, E. and R. Aguirre (1998). Discursos, acciones y controversias de la política gubernamental frente a la pobreza. In R. Gallardo and J. Osorio (Eds.), Los rostros de la pobreza. El debate, tomo 1. Mexico City: ITESO-Universidad Iberoamericana.

Valencia Lomelí, E., M. Gendreau and A. M. Tepichín Valle (Eds.) (2000). Los dilemas de la política social: ¿cómo combatir la pobreza? Mexico City: Universidad de GuadalajaraUniversidad Iberoamericana-ITESO.

Valencia Lomelí, E. (2008). Conditional cash transfers as social policy in Latin America: An assessment of their contributions and limitations. Annual Review of Sociology 34, 475-99.

Veras Soares, F. and T. Britto (2007). Confronting capacity constraints on conditional cash transfers in Latin America: The cases of El Salvador and Paraguay. Working Paper 38. Brasilia: IPC.

Veras Soares, F., R. Perez Ribas, and R. Guerreiro Osório (2010). Evaluating the impact of Brazil's Bolsa Família: Cash transfer programs in comparative perspective. Latin American Research Review 45(2), 173-190.

Villatoro, P. (2005). Conditional cash transfer programmes: Experiences from Latin America. CEPAL Review 86, 83-96.

Weber, M. (1968). Economy and Society: An Outline of Interpretive Sociology. New York: Bedminster Press.

Woolcock, M. and D. Narayan (2004). Capital social: implicaciones para la teoría, la investigación y las politicas sobre desarrollo. Polycopied document. Mexico City.

Woolley, F. and J. Marshall (1994). Measuring inequality within the household. Review of Income and Wealth 40(4), 415-431.

World Bank (WB) (1990). World Development Report 1990. Oxford: Oxford University Press.

WB (2001). World Development Report 2000/2001, Attacking Poverty: Opportunity, Empowerment and Security. Washington, D.C.: World Bank.

WB (2003). Gender Equality and the Millennium Development Goals. Washington, D.C.: WB.

WB (2006). Gender Equality as Smart Economics: A World Bank Group Gender Action Plan (Fiscal years 2007-10). Washington, D.C.: WB. 
WB (2009). Conditional Cash Transfers. Reducing Present and Future Poverty. Washington, D.C.: WB.

WB (2012). World Development Report 2012: Gender Equality and Development. Washington, D.C.: WB.

World Health Organisation (WHO) (2005). WHO's Multi-country Study on Women's Health and Domestic Violence Against Women. Geneva: WHO.

Yin, R.K. (2014). Case Study Research: Design and Methods. Thousand Oaks, CA: Sage.

Zelizer, V. (1989). The social meaning of money: "Special Monies". American Journal of Sociology 95(2), 342-377.

Zelizer, V. (1997). The Social Meaning of Money: Pin Money, Paychecks, Poor Relief, and Other Currencies. Princeton: Princeton University Press.

Zimmerman, M. (2000). Empowerment theory. Psychological, organizational and community levels of analysis. In J. Rappaport and E. Seidam (Eds.), Handbook of Community Psychology. New York: Kluwer Academic/Plenum Publishers. 